c. 3

\title{
Navigation Simulation Study, Galveston Causeway, Chocolate Bayou, Texas City Wye, Intracoastal Waterway, Texas
}

by Donald C. Wilson, Dennis W. Webb, Peggy S. Van Norman

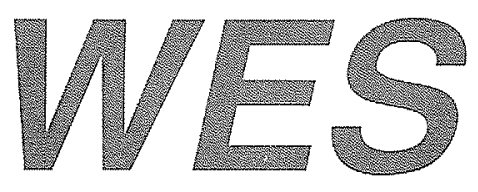

Approved For Public Release; Distribution Is Unlimited

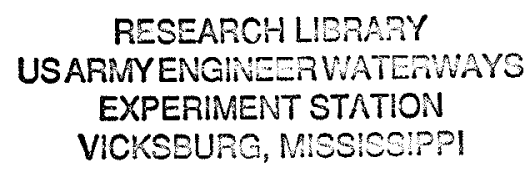

Prepared for U.S. Army Engineer District, Galveston 
The contents of this report are not to be used for advertising, publication, or promotional purposes. Citation of trade names does not constitute an official endorsement or approval of the use of such commercial products.

The findings of this report are not to be construed as an official Department of the Army position, unless so designated by other authorized documents.

8. PRinted on ReCycled paper

USACEWES

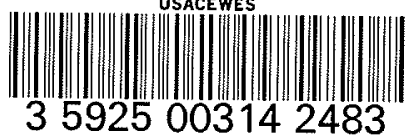




\section{Navigation Simulation Study, Galveston Causeway, Chocolate Bayou, Texas City Wye, Intracoastal Waterway, Texas}

by Donald C. Wilson, Dennis W. Webb, Peggy S. Van Norman

U.S. Army Corps of Engineers

Waterways Experiment Station

3909 Halls Ferry Road

Vicksburg, MS 39180-6199

Final report

Approved for public release; distribution is unlimited 


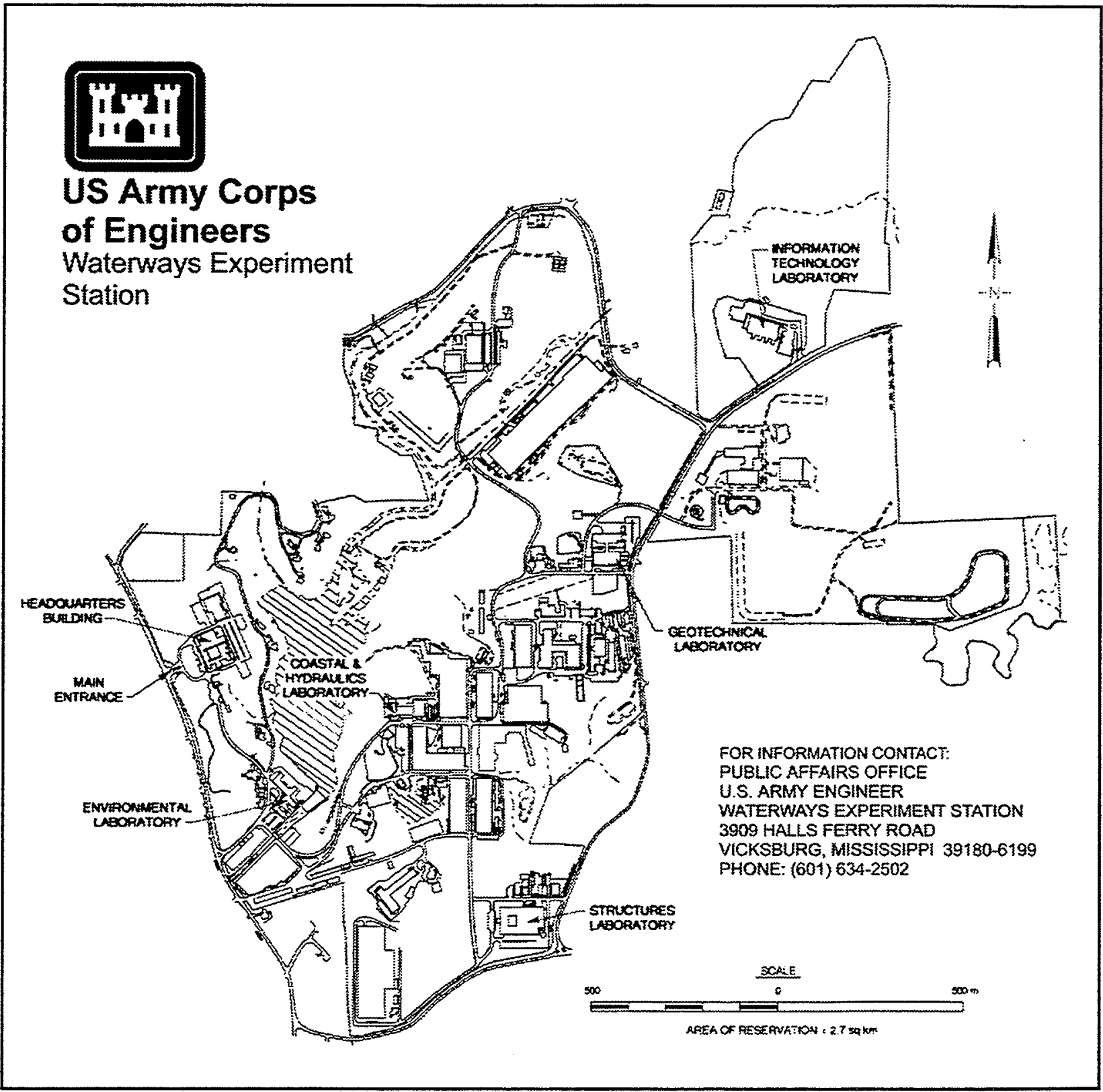

Waterways Experiment Station Cataloging-in-Publication Data

Wilson, Donald C.

Navigation simulation study, Galveston Causeway, Chocolate Bayou, Texas City Wye, Intracoastal Waterway, Texas / by Donald C. Wilson, Dennis W. Webb, Peggy S. Van Norman ; prepared for U.S. Army Engineer District, Galveston.

139 p. : ill. ; $28 \mathrm{~cm}$. - (Technical report ; CHL-99-5)

Includes bibliographic references.

1. Navigation - Texas - Simulation methods. 2. Chocolate Bayou (Tex.) 3. Channels (Hydraulic engineering) - Texas - Design and construction. 4. Texas City Wye (Tex.) 5. Causeways - Texas - Galveston. I. Webb, Dennis W. II. Van Norman, Peggy S. III. United States. Army. Corps of Engineers. Galveston District. IV. U.S. Army Engineer Waterways Experiment Station. V. Coastal and Hydraulics Laboratory (U.S. Army Engineer Waterways Experiment Station) VI. Title. VII. Series: Technical report (U.S. Army Engineer Waterways Experiment Station) ; CHL-99-5.

TA7 W34 no.CHL-99-5 


\section{Contents}

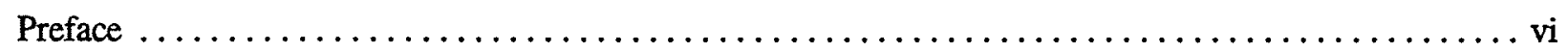

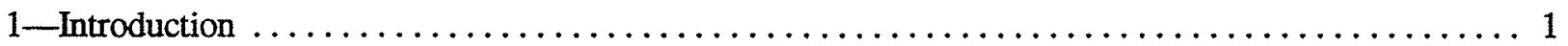

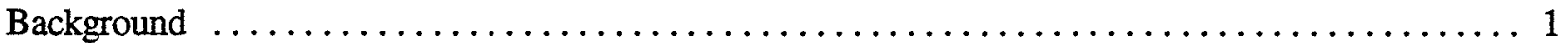

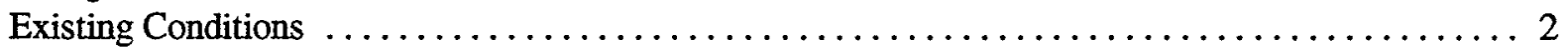

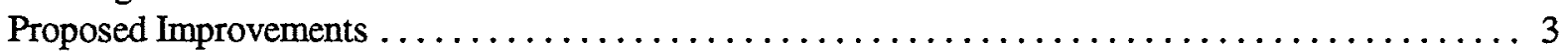

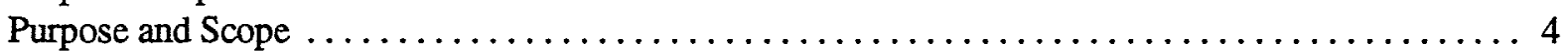

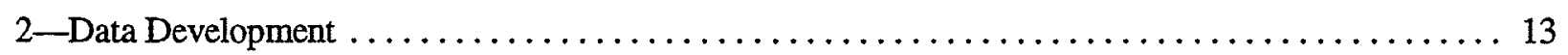

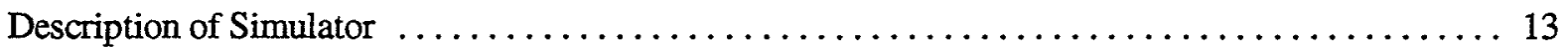

Required Data . . . . . . . . . . . . . . . . . .

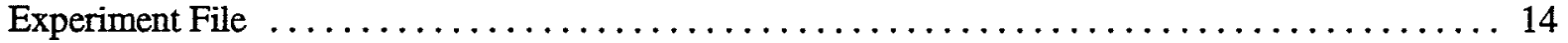

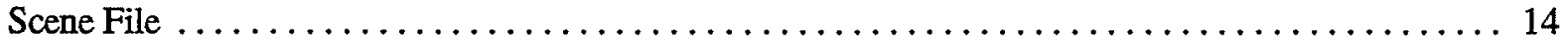

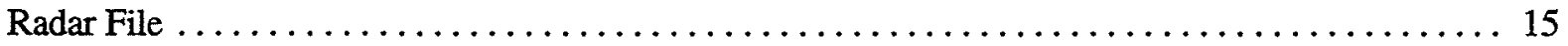

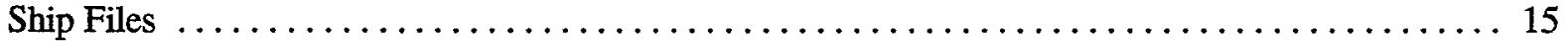

Current Files ............................................. 15

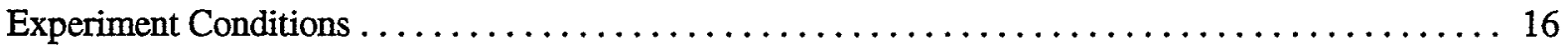

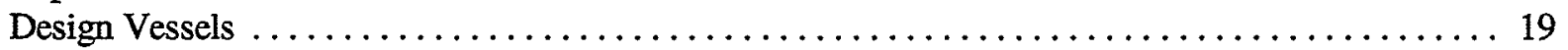

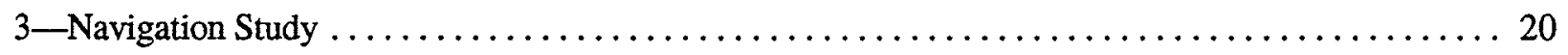

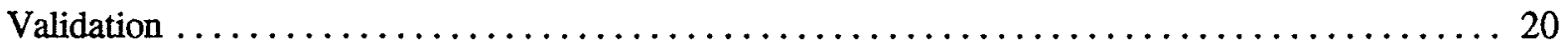

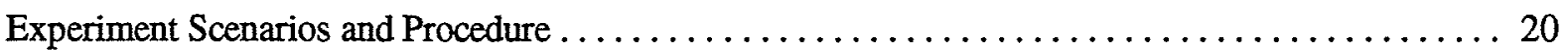

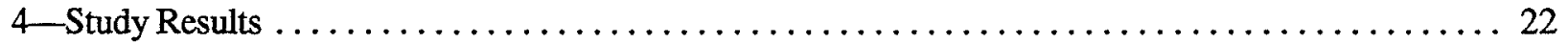

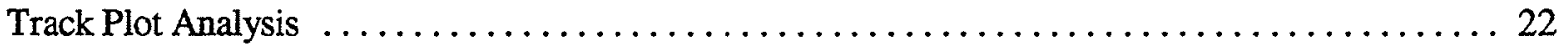

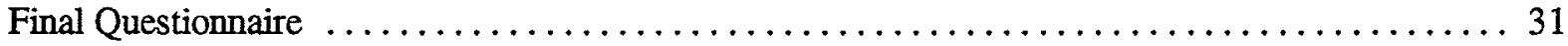

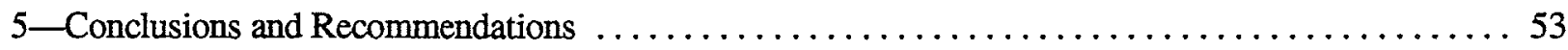

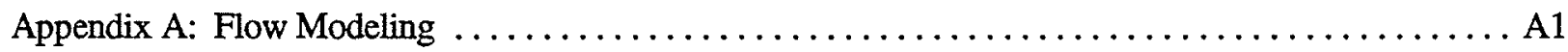

Plates 1-76

SF 298 


\section{LIST OF FIGURES}

Figure 1. Location and Area Map $\ldots \ldots \ldots \ldots \ldots \ldots \ldots \ldots \ldots \ldots \ldots \ldots \ldots$

Figure 2. Galveston Causeway, Existing Condition $\ldots \ldots \ldots \ldots \ldots \ldots \ldots \ldots$

Figure 3. Chocolate Bayou, Existing Condition $\ldots \ldots \ldots \ldots \ldots \ldots \ldots \ldots \ldots \ldots \ldots \ldots \ldots$

Figure 4. Texas City Wye, Existing Condition $\ldots \ldots \ldots \ldots \ldots \ldots \ldots \ldots \ldots \ldots$

Figure 5. Galveston Causeway, Plan $1 \ldots \ldots \ldots \ldots \ldots \ldots \ldots \ldots \ldots \ldots \ldots$

Figure 6. Galveston Causeway, Plan $2 \ldots \ldots \ldots \ldots \ldots \ldots \ldots \ldots \ldots$

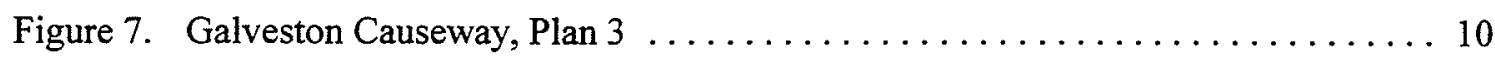

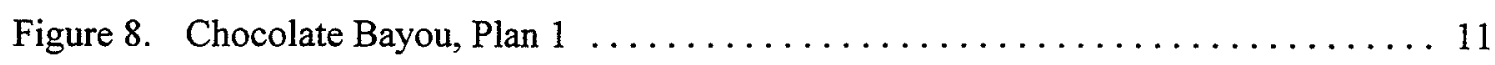

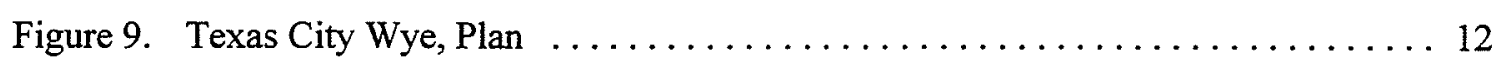

Figure 10. Final Questionnaire: Galveston Causeway, Pilot $1 \ldots \ldots \ldots \ldots \ldots \ldots \ldots$

Figure 11. Final Questionnaire: Chocolate Bayou, Pilot $1 \ldots \ldots \ldots \ldots \ldots \ldots$

Figure 12. Final Questionnaire: Texas City Wye, Pilot $1 \ldots \ldots \ldots \ldots \ldots \ldots \ldots$

Figure 13. Final Questionnaire: Galveston Causeway, Pilot $2 \ldots \ldots \ldots \ldots \ldots \ldots$

Figure 14. Final Questionnaire: Chocolate Bayou, Pilot $2 \ldots \ldots \ldots \ldots \ldots \ldots$

Figure 15. Final Questionnaire: Texas City Wye, Pilot $2 \ldots \ldots \ldots \ldots \ldots \ldots$

Figure 16. Final Questionnaire: Galveston Causeway, Pilot $3 \ldots \ldots \ldots \ldots \ldots \ldots \ldots$

Figure 17. Final Questionnaire: Texas City Wye, Pilot $3 \ldots \ldots \ldots \ldots \ldots \ldots \ldots \ldots$

Figure 18. Final Questionnaire: Galveston Causeway, Pilot $5 \ldots \ldots \ldots \ldots \ldots \ldots$

Figure 19. Final Questionnaire: Chocolate Bayou, Pilot $5 \ldots \ldots \ldots \ldots \ldots \ldots$

Figure 20. Final Questionnaire: Texas City Wye, Pilot $5 \ldots \ldots \ldots \ldots \ldots \ldots \ldots$

Figure 21. Final Questionnaire: Galveston Causeway, Pilot $6 \ldots \ldots \ldots \ldots \ldots \ldots$

Figure 22. Final Questionnaire: Chocolate Bayou, Pilot $6 \ldots \ldots \ldots \ldots \ldots \ldots$

Figure 23. Final Questionnaire: Texas City Wye, Pilot $6 \ldots \ldots \ldots \ldots \ldots \ldots \ldots \ldots \ldots$ iv 
Figure 24. Chocolate Bayou, Recommended Plan $1 \ldots \ldots \ldots \ldots \ldots \ldots \ldots \ldots \ldots \ldots \ldots \ldots$

Figure 25. Texas City Wye, Recommended Modification to Proposed Plan ........ 55

Figure 26. Composite Track Plot, All Proposed Plan Runs $\ldots \ldots \ldots \ldots \ldots \ldots \ldots$

\section{LIST OF TABLES}

Table 1. Galveston Causeway Approach Experiment Conditions $\ldots \ldots \ldots \ldots \ldots \ldots$

Table 2. Texas City Wye Experiment Conditions $\ldots \ldots \ldots \ldots \ldots \ldots \ldots \ldots \ldots \ldots \ldots$

Table 3. Chocolate Bayou Experiment Conditions $\ldots \ldots \ldots \ldots \ldots \ldots \ldots \ldots \ldots$

Table 4. Design tows for GIWW Simulation $\ldots \ldots \ldots \ldots \ldots \ldots \ldots \ldots \ldots \ldots \ldots \ldots \ldots \ldots \ldots$

Table 5. Experiment and Validation Schedule $\ldots \ldots \ldots \ldots \ldots \ldots \ldots \ldots \ldots \ldots \ldots \ldots \ldots \ldots \ldots$ 


\section{Preface}

This investigation was performed by the Coastal and Hydraulics Laboratory (CHL) of the U.S. Army Engineer Waterways Experiment Station (WES), Vicksburg, MS, for the U.S. Army Engineer District, Galveston (SWG). The study was conducted with the WES research ship simulator during the period February - March 1998. SWG provided survey data of the prototype area.

The investigation was conducted by Mr. Donald C. Wilson, Mr. Dennis W. Webb, and Ms. Peggy S. Van Norman, Navigation Branch, Navigation and Harbors Division, CHL, under the direct supervision of Dr. Sandra K. Knight, Acting Chief, Navigation Branch. General supervision was provided by Dr. James R. Houston, Director, CHL; Mr. Charles C. Calhoun, Jr., Assistant Director, CHL; Mr. C. E. Chatham, Chief, Navigation and Harbors Division, CHL. Current modeling was conducted by Mr. Ben Brown, Tidal Hydraulics Branch, Estuary and Hydroscience Division, CHL. Mr. Gary Lynch, Ms. Moria Fong, Ms. Donna Derrick, and Ms. Shann Martin, Navigation Branch, assisted in the study.

Acknowledgment is made to Mr. Ed Reindl and Mr. Al Meyer, SWG, for cooperation and assistance at various times throughout the investigation. Special thanks go to Coastal Towing, Hollywood Marine, Inc., and Dixie Canal Group for participating in the study.

At the time of publication of this report, Acting Director of WES was COL Robin R. Cababa, EN.

The contents of this report are not to be used for advertising, publication, or promotional purposes. Citation of trade names does not constitute an official endorsement or approval of the use of such commercial products. 


\section{Introduction}

\section{Background}

The Gulf Intra coastal Waterway (GIWW) serves ports for more than 1,100 miles $(1800 \mathrm{~km})$ between Brownsville, Texas, and Appalachia Bay, Florida. It lies mainly behind barrier beaches and provides for the most part a 125-foot-wide, 12-foot-deep channel. ${ }^{1}$ The heaviest commercial activity is centered at New Orleans and extends eastward to the Black Warrior-Tombigbee river system at Mobile Bay, Alabama, and westward to the Major Texas ports. Among the principal items moved on the route are petroleum and its products, industrial chemicals, pipe and other supplies for the oil fields, and sulfur.

The U.S. Army Engineer District, Galveston (SWG) has proposed channel improvements for three reaches of the GIWW. The locations of the three projects (Galveston Causeway, Texas City Wye, and Chocolate Bayou) are shown in Figure 1. To determine the navigation performance of the proposed improvements, SWG has requested the U.S. Army Waterways Experiment Station (WES) investigate the proposed improvements. The WES study is described in this report and study results are presented.

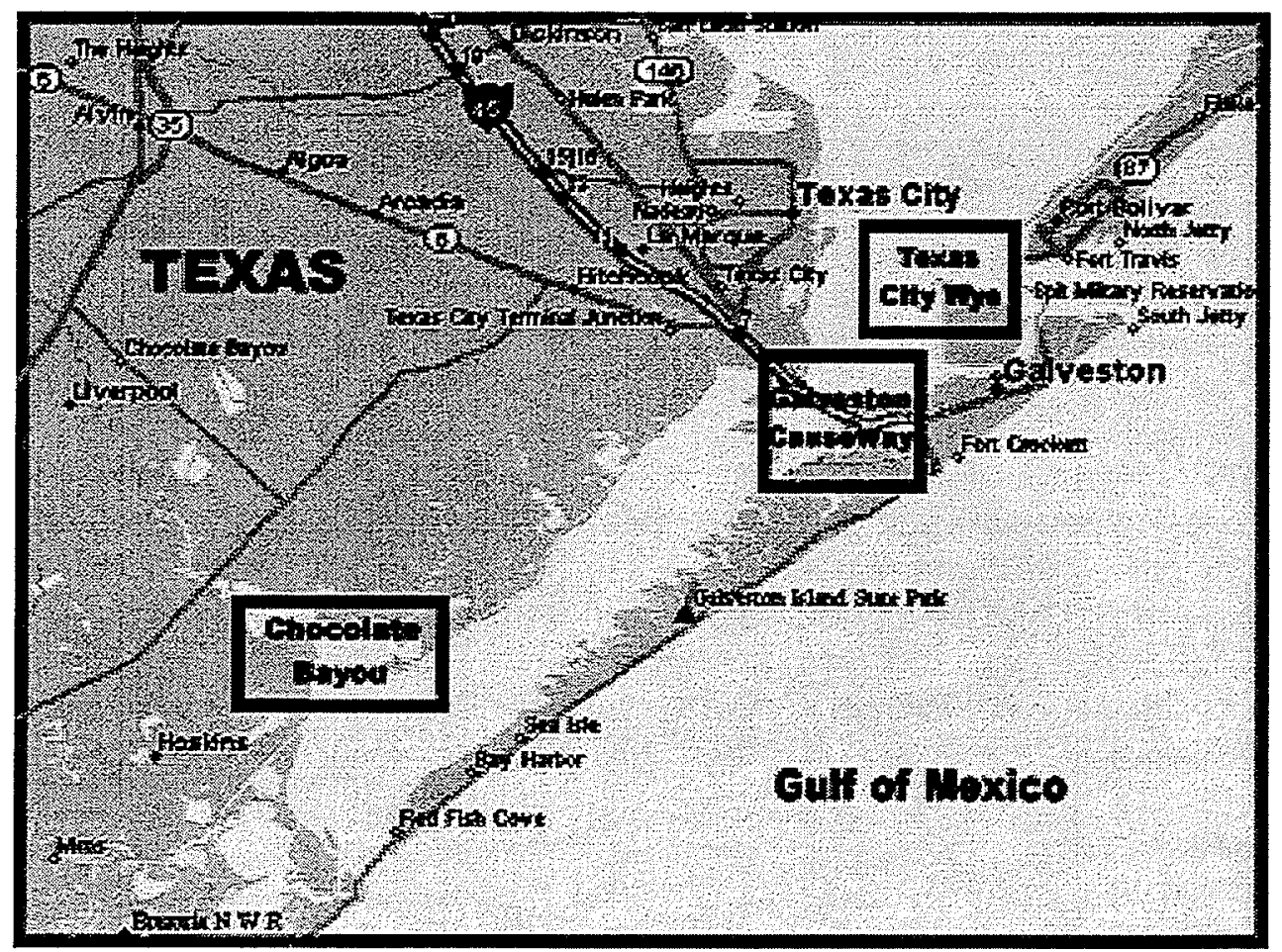

Figure 1. Location and area map.

1 To convert feet to meters, multiply by 0.3048 


\section{Existing Condition}

\section{Galveston Causeway}

The Galveston Causeway reach of the GIWW creates a navigation bottleneck for barge traffic and is difficult to transit safely during moderate to high winds or strong currents. The existing channel design and bridge openings were based on $35 \mathrm{ft}$ wide barge one way traffic that is now obsolete. The design vessels used today are both wider and longer with a higher cargo volume. Since a bridge channel widening would require extensive time to develop, and may be too costly to construct, an interim plan of study was proposed to improve the navigation approaches to the bridges. The Galveston District coordinated and requested a WES barge simulation model study for development of improvements to barge navigation approaches at the bridge.

The Galveston Causeway reach of the GIWW (Figure 2) consists of two reverse curves and two bridges ( the I-45 Hwy bridge or Galveston Causeway and the G.H.\&H. Railroad Bridge) spaced $510 \mathrm{ft}$ apart. The I-45 Hwy bridge is also referred to as the Galveston Causeway. The channel is $200 \mathrm{ft}$ wide in the $3700 \mathrm{ft}$ radius bend immediately west of the Causeway before transitioning to $125 \mathrm{ft}$ wide in the approximately $2150 \mathrm{ft}$ long straight section approaching the Causeway. The channel then transitions to $110 \mathrm{ft}$ wide through a $800 \mathrm{ft}$ long wooden fender system that protects the bridge piers of the I-45 Hwy bridge and the abutments of the G.H.\&H. Railroad bridge. On the East side of the Causeway the channel transitions back to a $125 \mathrm{ft}$ wide channel and continues straight for approximately $1915 \mathrm{ft}$ until it transitions to a $3400 \mathrm{ft}$ radius bend that is 200 $\mathrm{ft}$ wide.

\section{Chocolate Bayou}

The intersection of Chocolate Bayou and the GIWW is located in Brazoria County about 20 miles southwest of the Galveston Island Causeway. The existing Chocolate Bayou intersection and turn into the GIWW has been difficult to both maintain for dredging and mark for navigation. Many barges are unable to stay within the channel in this area, especially multiple barge tows during windy weather. Though much of the area near the coast has little development in the low marshy plain, the Chocolate Bayou main channel extends inland several miles for commercial use. Alvin and Angleton, Texas are the largest cities located within a 30-mile diameter of influence.

The existing intersection of the GIWW and Chocolate Bayou consists of an east channel and a west channel (Figure 3 ). These two channels, commonly referred to as the East Wye and the West Wye, join approximately $2100 \mathrm{ft}$ north of the GIWW into Chocolate Bayou. The West Wye consists of a $125 \mathrm{ft}$ wide $1814 \mathrm{ft}$ radius bend and the East Wye is a $125 \mathrm{ft}$ wide $2815 \mathrm{ft}$ radius bend.

\section{Texas City Wye}

The intersection of the GIWW and the Texas City channel is located approximately 6112 miles northeast of the Galveston Island Causeway. Navigation conditions for tows negotiating the turn at the intersection are difficult during high winds or strong currents. There is an existing channel (Texas City Wye) that cuts across the northwest corner of the intersection that is $125 \mathrm{ft}$ wide and is a smooth $2550 \mathrm{ft}$ radius curve (Figure 4). The intersection of the Texas City Wye and the GIWW is 
approximately $400 \mathrm{ft}$ northeast from a barge mooring area that makes navigation conditions more difficult when barges are there. However, due to frequent shoaling and minimal channel width, barge captains from the area report that the channel is not currently used. Instead, tows navigating the reach, make the hard turn at the intersection. The focus of this investigation was the section of the GIWW immediately to the west of the Texas City channel, including the Pelican Cut mooring area and the section of the Texas City channel north of the GIWW.

\section{Proposed Improvements}

The improvements proposed for Galveston Causeway, Chocolate Bayou and Texas City Wye were developed jointly by representatives of SWG, WES and the towing industry.

\section{Galveston Causeway}

In an attempt to improve navigation conditions through the Galveston Causeway, SWG requested WES to conduct experiments with two proposed channel modifications. Plan 1, as shown in Figure 5, consists of the following revisions. Beginning at the point of tangency (PT) in the bend on the south side of the causeway, the channel will transition from a $200 \mathrm{ft}$ wide channel to a $250 \mathrm{ft}$ wide channel at a point approximately $1200 \mathrm{ft}$ south of the fender system. The channel will then transition from $250 \mathrm{ft}$ wide back to it's original width at the fender system. On the north side of the causeway, the channel will transition from $200 \mathrm{ft}$ wide beginning at the PT of the bend just north of the causeway to $600 \mathrm{ft}$ wide at a point approximately $1200 \mathrm{ft}$ north of the fender system. The channel will then transition back to $125 \mathrm{ft}$ wide at the fender system. Four Dolphins, spaced about $300 \mathrm{ft}$ apart, will be constructed on the east side of the channel and four dolphins will be constructed on the west side of the channel beginning at the fender system creating a flared approach to the north side of the G.H.\&H. Railroad Bridge. Plan 2, as shown in Figure 6, consists of extending the $200 \mathrm{ft}$ wide channel on both sides of the causeway to the fender system. On the northt side of the causeway, two dolphins will be constructed on each end of the fender system. On the south side of the causeway four dolphins spaced $300 \mathrm{ft}$ apart will be constructed on each side of the channel similar to the dolphins on the north side in Plan 1.

During the final week of experimentation, personnel from SWG and WES designed a third plan for Galveston Causeway (Figure 7). This plan, designated Plan 3, consisted of a major realignment of the navigation channel in the vicinity of the Galveston Causeway. This realignment resulted in lengthening the straight channel on both sides of the causeway. The straight channel approach was increased on the west side of the causeway from $2600 \mathrm{ft}$ to $5950 \mathrm{ft}$ and on the east side from $3000 \mathrm{ft}$ to $8450 \mathrm{ft}$.

\section{Chocolate Bayou}

Figure 8 shows the plan proposed by SWG to improve navigation conditions for tows entering and exiting Chocolate Bayou. This plan, designated Plan 1, consists of eliminating the East and West Wye channels by widening the entire intersection and deepening to $12 \mathrm{ft}$. Tows entering Chocolate Bayou from the west will encounter a 1237 $\mathrm{ft}$ radius turn and tows entering from the east will encounter a $981 \mathrm{ft}$ radius bend. 


\section{Texas City Wye}

The channel improvement proposed by SWG for the intersection of the GIWW and the Texas City Channel is shown in Figure 9. This plan, designated Plan 1, consists of eliminating the existing channel on the west side of the Texas City Channel and widening the intersection of the GIWW and Texas City Channels.

\section{Purpose and Scope}

In order to evaluate the proposed plans for channel improvement at Galveston Causeway, Texas City Wye and Chocolate Bayou, a real-time simulation investigation was conducted. The purpose of the study was to determine the effects of proposed improvements on navigation and to assist in optimizing channel width and alignment for efficient navigation of the study areas.

The study described in this report was performed by WES Coastal and Hydraulics Laboratory $(\mathrm{CHL})$. The approach consisted of the following tasks:

a. Develop data required in navigation simulation.

b. Validate the navigation simulations of Galveston Causeway, Texas City Wye and Chocolate Bayou.

c. Conduct real-time navigation simulations of existing and proposed plans for Galveston Causeway, Texas City Wye and Chocolate Bayou.

d. Evaluate effectiveness of proposed plans for meeting navigation requirements.

These tasks are discussed in the following chapters. Conclusions and recommendations are given in Chapter 5 . That chapter is followed by an appendix with detailed information on flow modeling done in support of the navigation simulation study . 


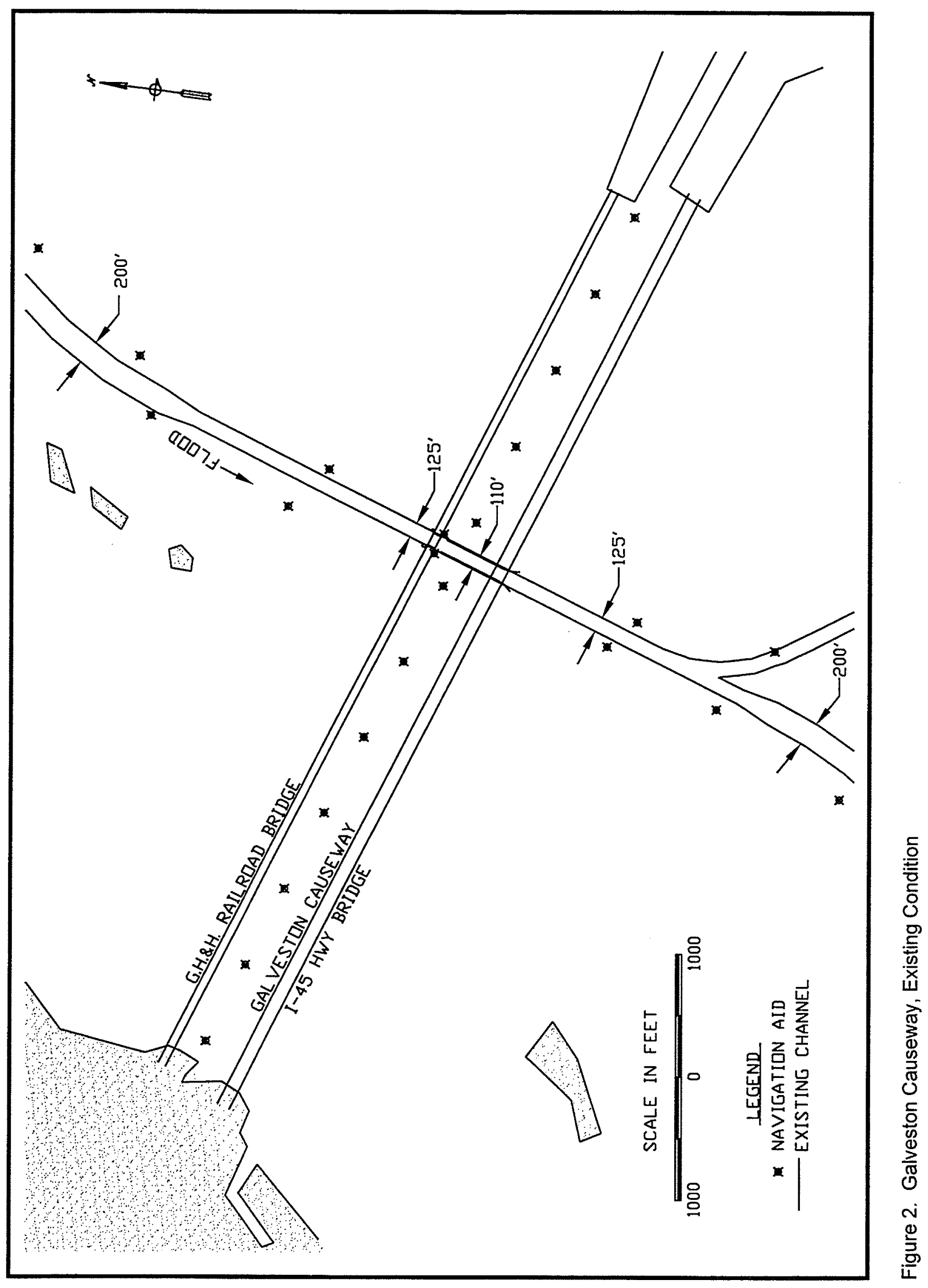

Chapter 1 Introduction 


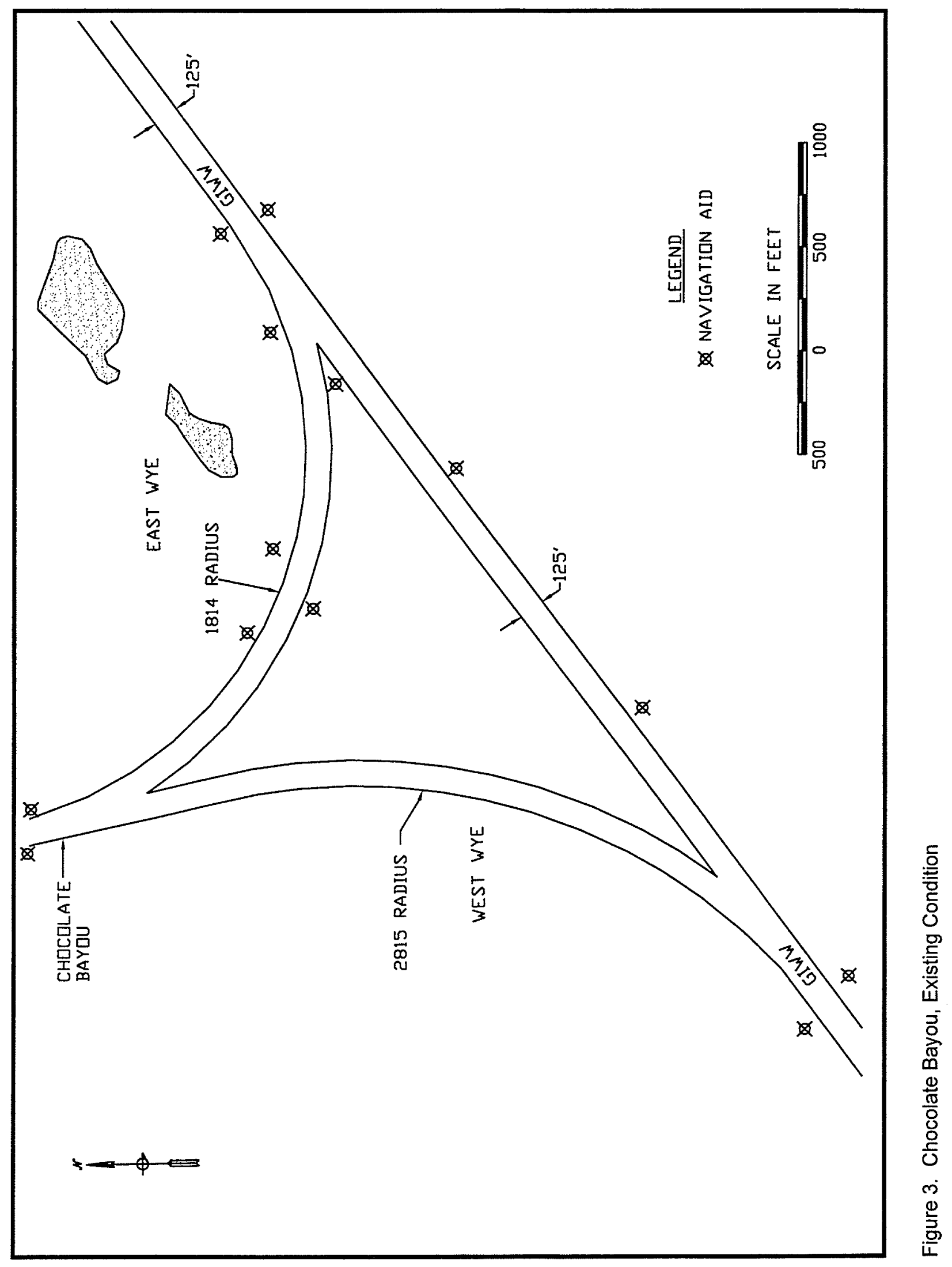




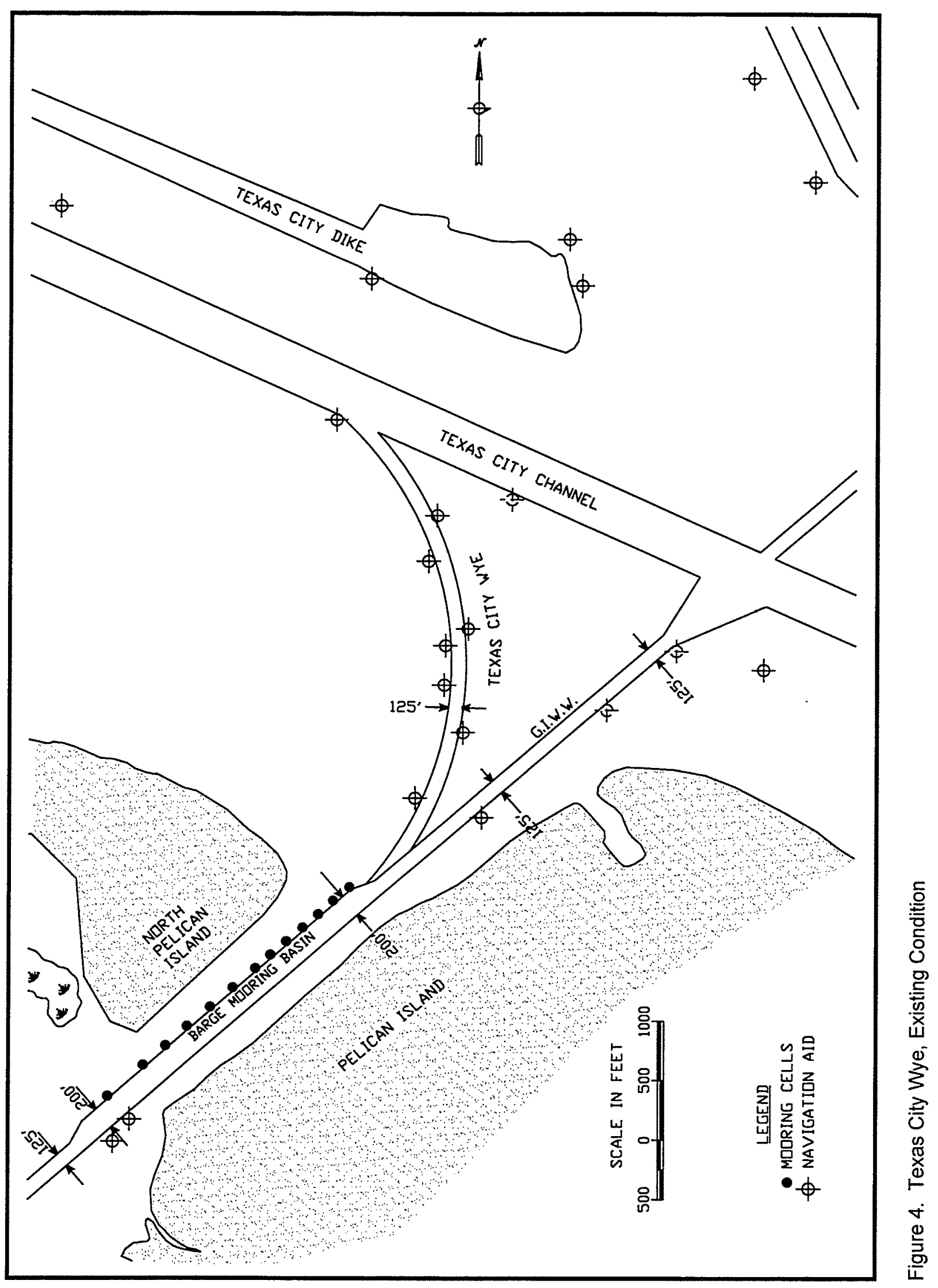




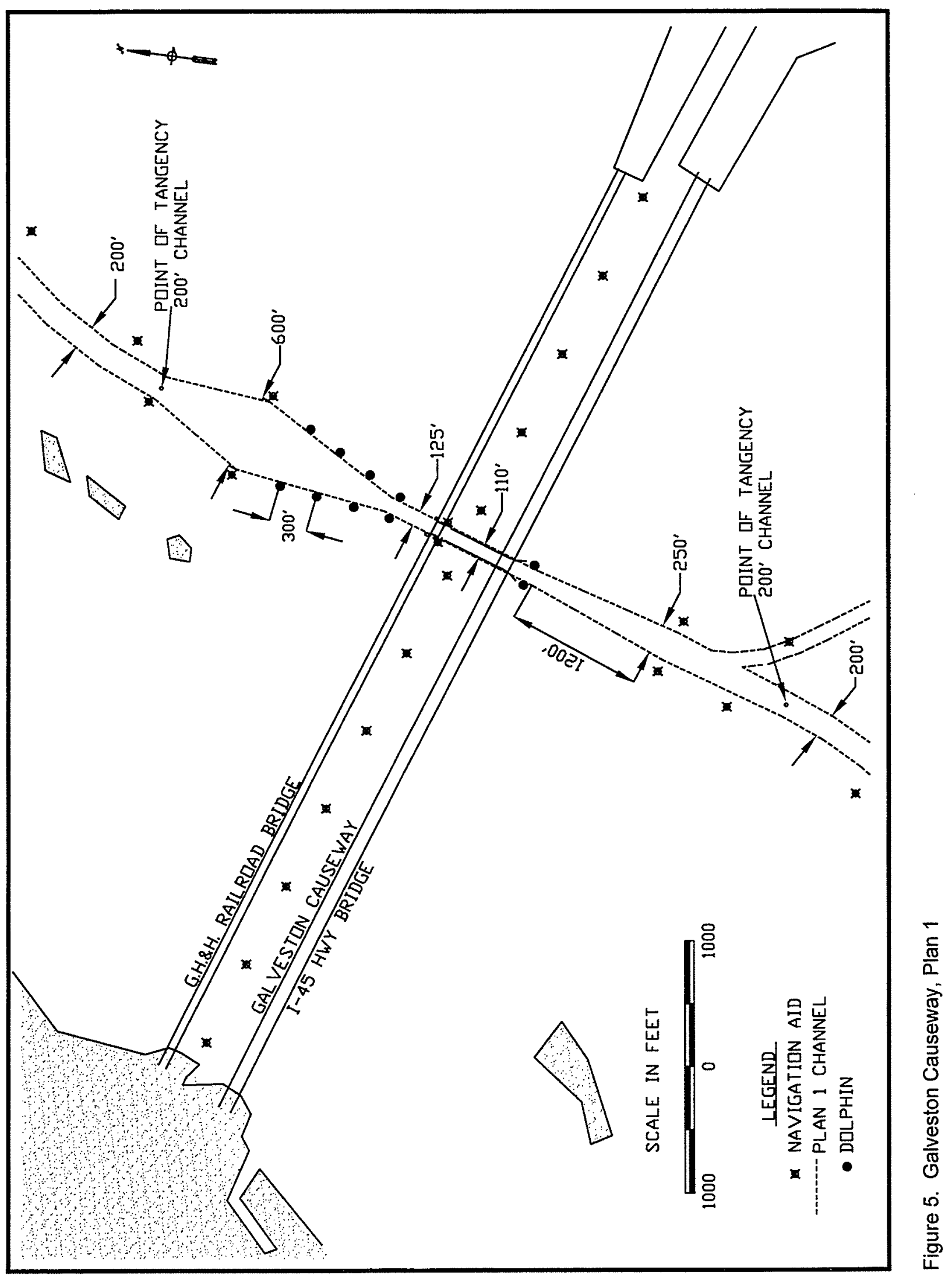




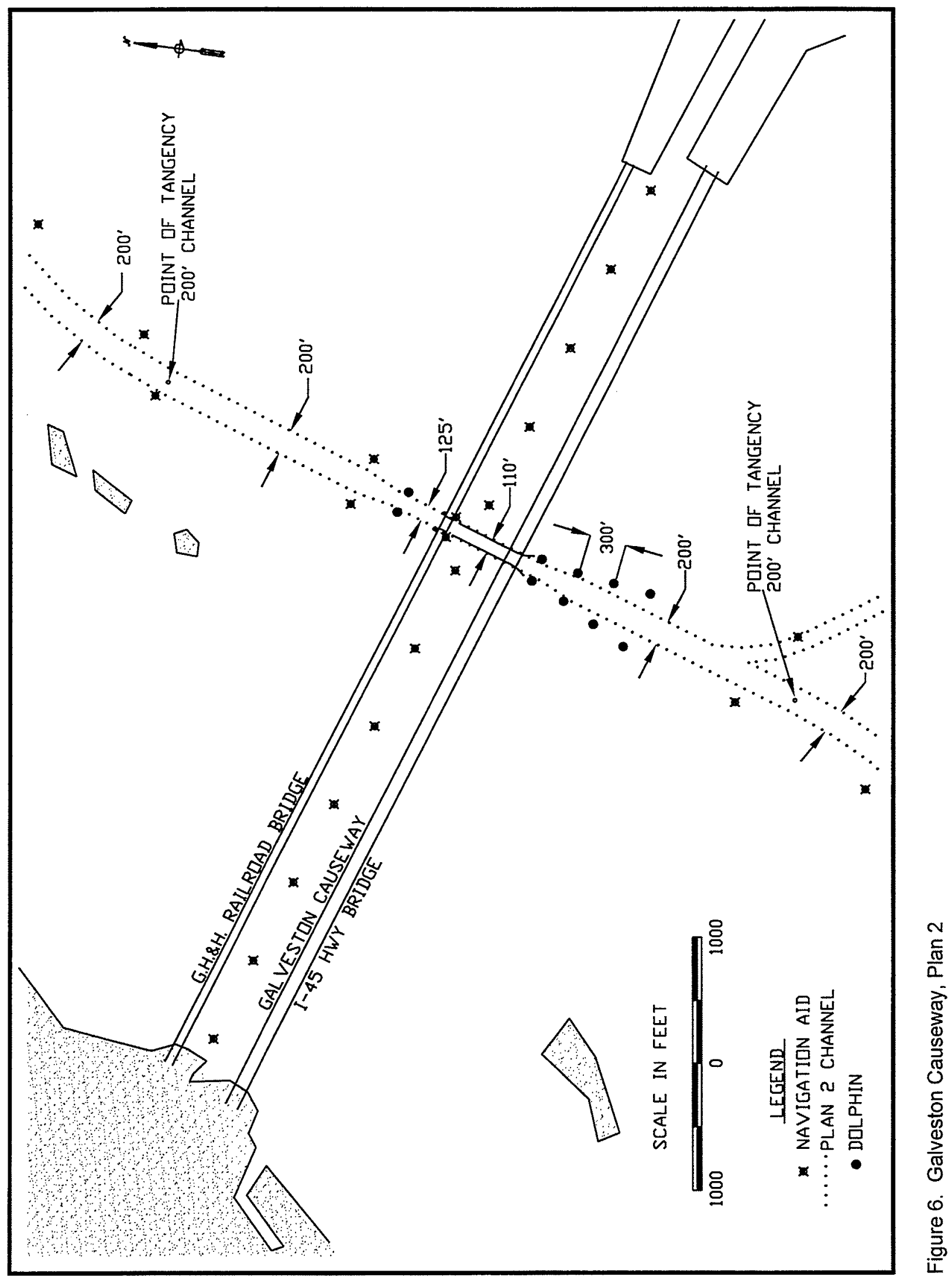




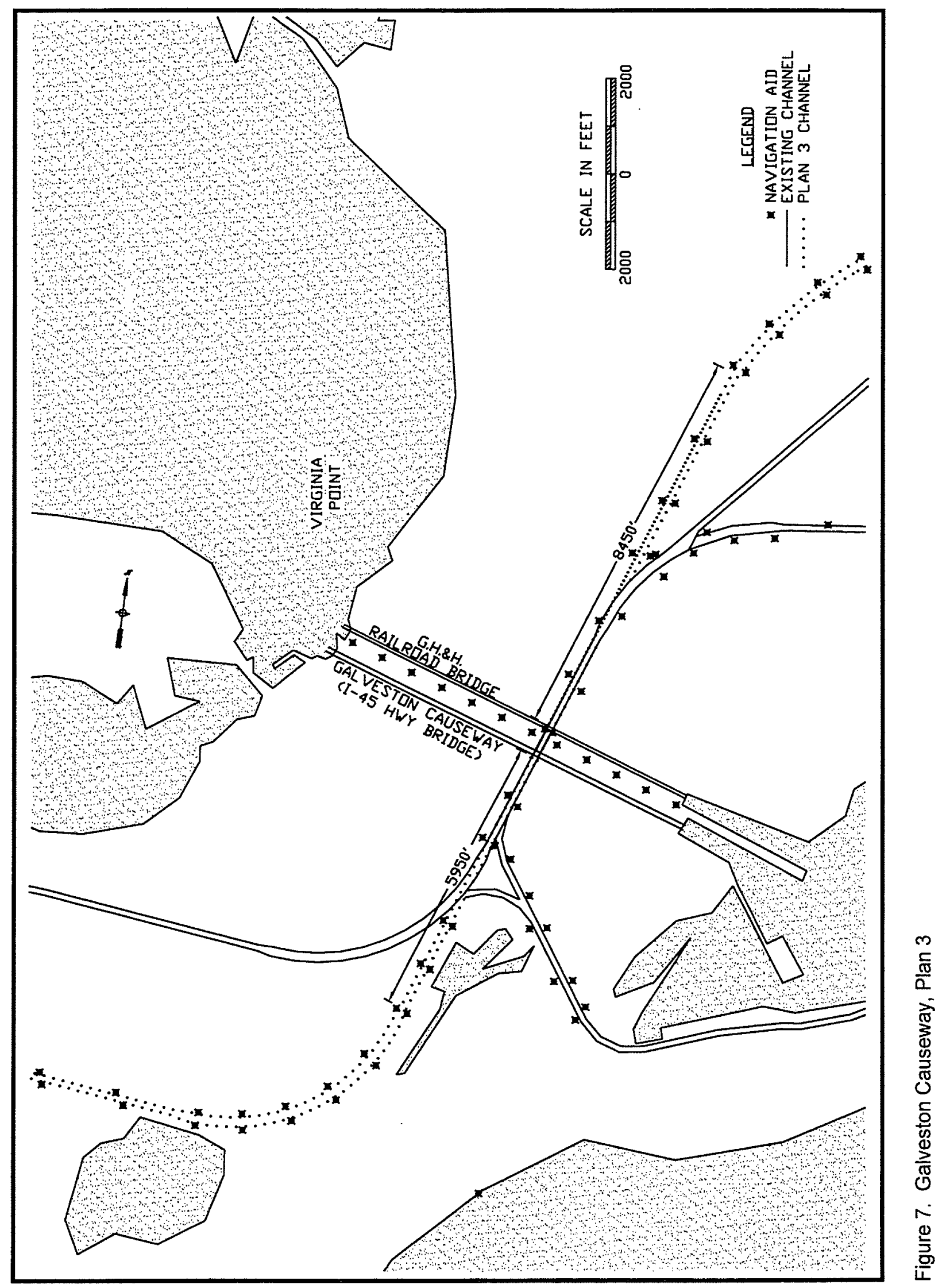




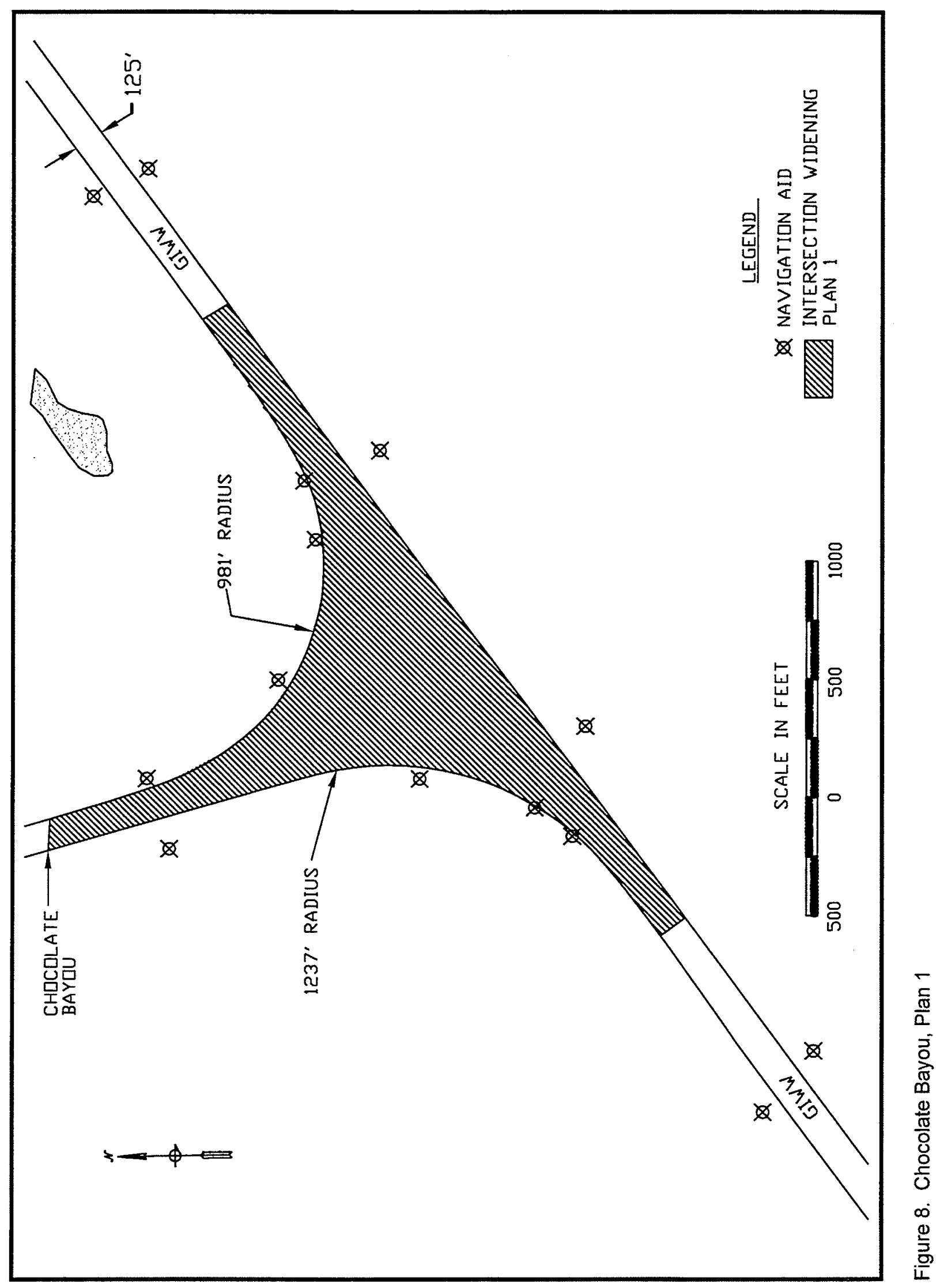




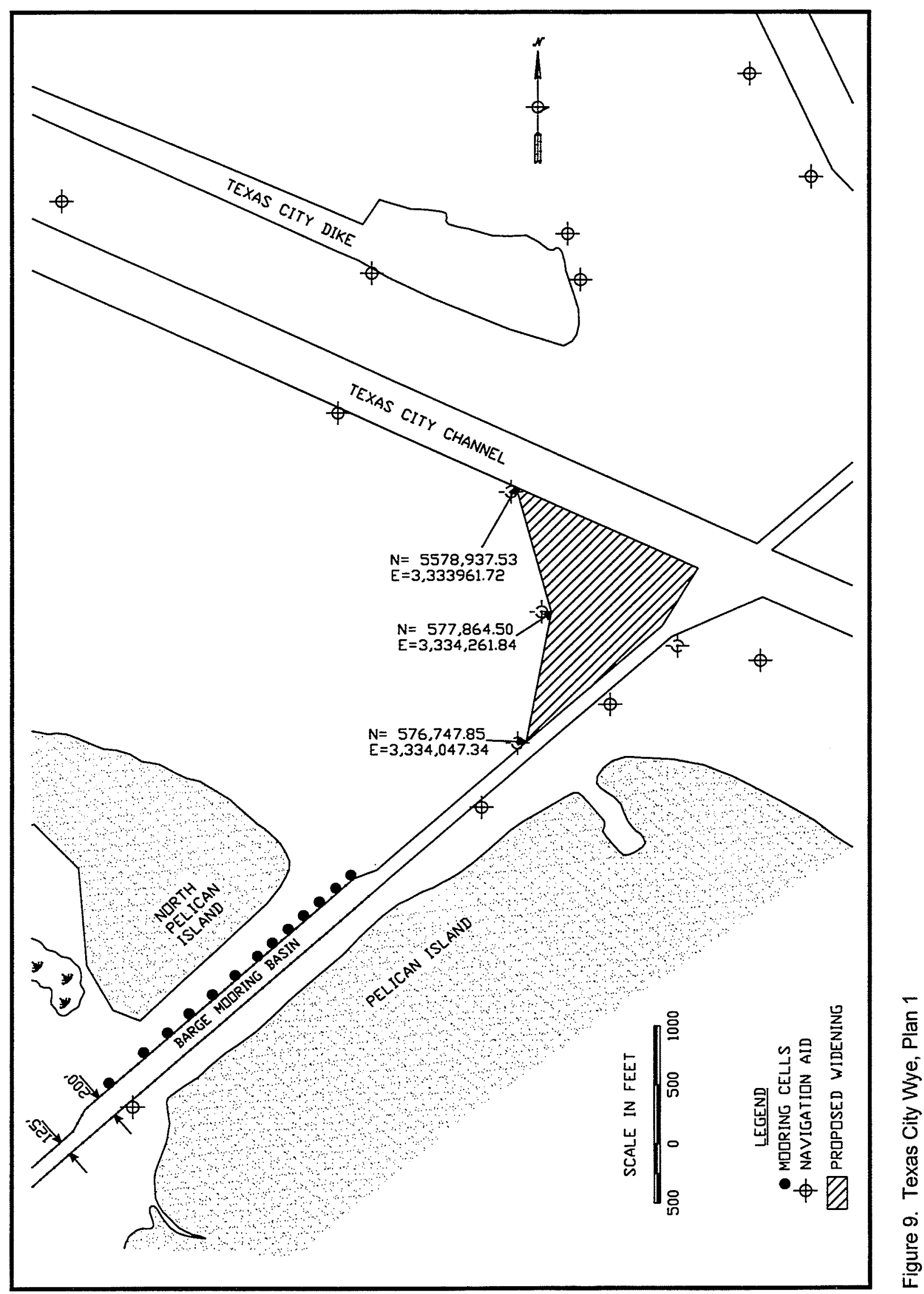




\section{Data Development}

\section{Description of Simulator}

It is beyond the scope of this report to describe, other than briefly, the WES ship/tow simulator. The purpose of the WES ship/tow simulator is to provide the essential factors necessary in a controlled computer environment to allow the inclusion of the man-in-the-loop, i.e., vessel pilots, in the navigation channel design process. The simulator is operated in real-time by a pilot licensed for the area being studied. His commands are transferred to the computer through a navigation console connected through a personal computer to the main simulation computer, the Silicon Graphics Onyx. The visual scene is displayed upon three rear-screen projectors that provide approximately 140 degrees fieldof-view. The visual scene is updated 7 to 10 times per second as the hydrodynamic portion of the simulator program computes a new ship's position and heading resulting from manual input from the pilot (driving rudder, flanking rudder, or engine throttle) and external forces acting upon the vessel. The external force capability of the simulator includes effects of wind, waves, currents, banks, shallow water effects, ship/ship interaction, and tugboats. In addition to the visual scene, pilots are provided simulated radar and other navigation information such as water depth, relative ground and water speed of the vessel, magnitude of lateral vessel motions, relative wind speed and direction, and ship's heading.

\section{Required Data}

Data required for the simulation study included channel plan geometry, bottom topography, channel currents for proposed as well as existing conditions, mathematical models of experiment vessels, and visual data of the study area. Dredging survey sheets provided by SWG were used for establishing channel depth and alignments. Navigation Charts were used to define the land outline as well as topography. Current data was obtained from a RMA-2V finite element numerical model of Galveston Bay and the surrounding area (Appendix A). A reconnaissance trip was carried out with the assistance of local towing companies for the purpose of gathering data and observing actual towboat operations in the Galveston Causeway and Texas City Dike areas. Still photographs and video footage were taken during the reconnaissance transits to aid in the construction of the simulated visual scene. During the towboat transit, discussions with the pilot helped WES engineers become more familiar with the concerns and problems experienced during tow operations 


\section{Experiment File}

The experiment file contains initial conditions (vessel speed and heading, rudder angle, and engine setting) for the simulation and geographical coordinates for the channel alignment being used. The channel is defined in terms of cross sections located to coincide with changes in channel alignment and current direction and magnitude. Information used for development of the Galveston Causeway, Texas City Wye and Chocolate Bayou reaches data base was obtained from SWG's project surveys. Plane coordinates on the survey sheets are based on a transverse Mercator projection for the south central zone of Texas. The same coordinate system was used for the simulator data base. Also included in the experiment file are bank steepness and overbank depth (water depth at the top of the side slope) adjacent to the channel. These data are used by the computer to calculate bank effect forces on vessels in the simulation. Specifications of other external forces such as wind are also included in this file.

For the Galveston Causeway, Texas City Wye and Chocolate Bayou projects, simulator channel cross sections were placed approximately $500 \mathrm{ft}$ apart in straight, uniform channel areas. Since the channels were fairly uniform, simulator cross sections did not vary in spacing along much of the channel. Cross section spacing was reduced considerably in bends and in the immediate vicinity of the proposed modifications to insure good representation of changes in geometry and currents. The simulator program handles transition between cross-sections by linear interpolation between the two closest cross-sections.

Proposed plan water depths for the simulator were based on authorized project depths. For the simulated existing channel, water depths, and overbank depths were obtained from the April 1997 project condition survey. These data are used in calculating vessel hull bank forces. Bank forces occur when a vessel travels close to a submerged bank (also, wall or docked ship). The resulting effect is characterized by vessel movement toward the bank and bow-out rotation away from the bank.

\section{Scene File}

The scene database comprises several data files containing geometrical information enabling the graphics computer to generate the simulated scene of the study area. The computer hardware and software used for visual scene generation are separate from the main computer of the ship simulator. The main computer provides motion and orientation information to a stand-alone graphics computer for correct vessel positioning in the scene, which is then viewed by the pilot. Operators view the scene as if they are standing in the pilothouse of the towboat looking toward the bow of the barges.

Aerial photographs, navigation charts, and dredging survey charts provided the basic data for generation of the visual scene. The simulations 
required low visual resolution beyond the immediate vicinity of the navigation channel. All land masses in the vicinity of the navigation channel were included in the scene. All aids to navigation in the vicinity of the study area were included. In addition to the man-made and topographical features in the vicinity, the visual scene included a perspective view of the bow of the barge from the pilot's viewpoint. Visual databases for all design ships were developed at WES.

\section{Radar File}

The radar file contains coordinates defining the border between land and water and significant man-made objects, such as docked ships, aids to navigation, and bridges. The radar database contains the same type of information available through a ship's radar. One major difference between them; however, is the detail and crispness of the simulated radar image. This change is purposeful and it helps to counteract the loss of perspective that occurs when using a 2-dimensional screen to view a 3-dimensional visual scene. Two radar screens are used for the simulation, a 0.25 mile range that remains visible at all times during the experimentation, and a variable screen radar that can be changed between $0.5,0.75$, and 1.5 mile ranges. The variable range radar can also be modified to supply any other range the pilot feels is necessary. The main information sources for this database were the project drawings and dredging survey sheets supplied by SWG.

\section{Ship Files}

The ship files contain characteristics and hydrodynamic coefficients for the design vessels. These data are the computer's definition of the ship. The coefficients govern the reaction of the ship to external forces, such as wind, current, waves, banks, underkeel clearance, and ship/ship interaction, and internal controls, such as rudder and engine revolutions per minute (rpm) commands. The vessels were selected based on SWG's economic analysis of future shipping business and operations.

\section{Current Files}

The current file contains current magnitude, direction, and water depth for each of eight points across each of the cross sections defining the channel alignment. Current information for a ship/tow simulation study is usually obtained from physical or numerical models. In this study, current information was generated with a numerical model of Galveston Bay (Appendix A). Current information for the proposed channel modifications were based on numerical modeling with the plan bathymetry. 


\section{Experiment Conditions}

The experiment scenarios, design vessels, and environmental conditions were selected in order to evaluate existing and proposed channels in the "maximum credible adverse situation," that is, the worst conditions under which the reaches would maintain normal operations. This approach provides a built-in safety factor when analyzing the results. The existing channel was included in order to provide a base with which to compare simulations of the proposed channels, and to provide a basis for comparison of conditions by pilots involved in the study. Experiment conditions are summarized in Tables 1-3 and discussed in the following paragraphs.

\section{Wind}

Two wind conditions were used during the simulations of Galveston Causeway, Texas City Wye and Chocolate Bayou. An 18-knot, gusting wind was imposed from either the northeast or southeast direction for all simulations. The "gusting" option means that winds in the simulator will randomly vary in direction and magnitude as compared to the values input into the computer. This option was selected by the captains during validation as the most accurate way to simulate actual conditions in the Galveston area. Empty barges are especially vulnerable to forces exerted by this representative moderately strong wind.

\section{Current}

Currents for each of the three study areas were derived from a RMA-2V model study conducted at WES (Appendix A). For the simulations, either the maximum flood or maximum ebb tide was used to generate the current information.

\begin{tabular}{|l|l|l|l|l|c||}
\hline \hline \multicolumn{5}{|l|}{$\begin{array}{l}\text { Table } 1 \\
\text { Galveston Causeway Approach Experiment Conditions }\end{array}$} \\
\hline \hline $\begin{array}{l}\text { Experiment } \\
\text { Condition }\end{array}$ & Channel & Direction & $\begin{array}{l}\text { Tow } \\
\text { Configuration }\end{array}$ & $\begin{array}{l}\text { Current } \\
\text { Direction }\end{array}$ & Wind \\
\hline \hline 1 & Existing & Eastbound & 2 barge loaded & Ebb & SE \\
\hline 2 & Existing & Eastbound & 2 barge empty & Ebb & NE \\
\hline 3 & Plan 1 & Westbound & 3 barge loaded & Flood & SE \\
\hline 4 & Plan 2 & Eastbound & 3 barge empty & Ebb & SE \\
\hline 5 & Plan 1 & Westbound & 2 barge empty & Flood & SE \\
\hline 6 & Existing & Westbound & 2 barge empty & Flood & SE \\
\hline 7 & Plan 1 & Eastbound & 3 barge empty & Ebb & NE \\
\hline 8 & Plan 1 & Westbound & 3 barge empty & Flood & NE \\
\hline \hline
\end{tabular}




\begin{tabular}{|c|c|c|c|c|c|}
\hline \multicolumn{6}{|c|}{ Table 1 (Concluded) } \\
\hline 9 & Plan 1 & Westbound & 2 barge empty & Flood & NE \\
\hline 10 & Plan 2 & Westbound & 3 barge loaded & Flood & $\mathrm{SE}$ \\
\hline 11 & Plan 1 & Eastbound & 2 barge empty & $\mathrm{Ebb}$ & $\mathrm{NE}$ \\
\hline 12 & Plan 2 & Westbound & 3 barge empty & Flood & $\mathrm{NE}$ \\
\hline 13 & Plan 1 & Eastbound & 3 barge empty & $\mathrm{Ebb}$ & SE \\
\hline 14 & Existing & Westbound & 2 barge loaded & Flood & SE \\
\hline 15 & Plan 2 & Eastbound & 2 barge empty & $E b b$ & $\mathrm{NE}$ \\
\hline 16 & Plan 2 & Westbound & 2 barge empty & Flood & $\mathrm{NE}$ \\
\hline 17 & Plan 2 & Eastbound & 2 barge empty & Ebb & SE \\
\hline 18 & Existing & Westbound & 2 barge empty & Flood & $\overline{N E}$ \\
\hline 19 & Plan 2 & Eastbound & 3 barge empty & Ebb & $\mathrm{NE}$ \\
\hline 20 & Plan 2 & Westbound & 3 barge empty & Flood & $\overline{S E}$ \\
\hline 21 & Plan 1 & Westbound & 3 barge empty & Flood & SE \\
\hline 22 & Plan 2 & Westbound & 2 barge empty & Flood & SE \\
\hline 23 & Existing & Eastbound & 2 barge empty & Ebb & SE \\
\hline 24 & Plan 1 & Eastbound & 2 barge empty & Ebb & SE \\
\hline 25 & Plan 2 & Eastbound & 3 barge loaded & Ebb & SE \\
\hline 26 & Plan 1 & Eastbound & 3 barge loaded & Ebb & SE \\
\hline 27 & Plan 2 & Eastbound & 3 barge loaded & Flood & SE \\
\hline 28 & Plan 2 & Westbound & 3 barge loaded & $E b b$ & SE \\
\hline 29 & Existing & Westbound & 2 barge loaded & $\mathrm{Ebb}$ & SE \\
\hline 30 & Plan 1 & Westbound & 3 barge loaded & $E b b$ & SE \\
\hline 31 & Existing & Eastbound & 2 barge loaded & Flood & SE \\
\hline 32 & Plan 1 & Eastbound & 3 barge loaded & Flood & SE \\
\hline 33 & Plan 1 & Westbound & 2 barge loaded & Ebb & SE \\
\hline 34 & Plan 2 & Eastbound & 2 barge loaded & Ebb & SE \\
\hline 35 & Plan 2 & Westbound & 2 barge loaded & Ebb & SE \\
\hline 36 & Plan 2 & Eastbound & 2 barge loaded & Flood & SE \\
\hline 37 & Plan 2 & Westbound & 2 barge loaded & Flood & SE \\
\hline 38 & Plan 1 & Eastbound & 2 barge loaded & Ebb & SE \\
\hline 39 & Plan 1 & Eastbound & 2 barge loaded & Flood & SE \\
\hline 40 & Plan 1 & Westbound & 2 barge loaded & Flood & $S E$ \\
\hline
\end{tabular}

\begin{tabular}{|c|c|c|c|c|c|}
\hline \multicolumn{6}{|c|}{$\begin{array}{l}\text { Table } 2 \\
\text { Texas City Wye Experiment Conditions (Inbound runs headed } \\
\text { into Texas City) }\end{array}$} \\
\hline $\begin{array}{l}\text { Experiment } \\
\text { Condition }\end{array}$ & Channel & Direction & $\begin{array}{l}\text { Tow } \\
\text { Configuration }\end{array}$ & $\begin{array}{l}\text { Current } \\
\text { Direction }\end{array}$ & Wind \\
\hline 1 & Existing & Inbound & 2 barge loaded & Ebb & SE \\
\hline 2 & Existing & Inbound & 2 barge loaded & Flood & $\overline{S E}$ \\
\hline 3 & Plan 1 & Inbound & 2 barge loaded & Ebb & SE \\
\hline
\end{tabular}




\begin{tabular}{|l|l|l|l|l|l||}
\hline \multicolumn{4}{|l|}{ Table 2 (concluded) } \\
\hline \hline 4 & Plan 1 & Inbound & 2 barge loaded & Flood & SE \\
\hline 5 & Existing & Outbound & 2 barge loaded & Ebb & SE \\
\hline 6 & Existing & Outbound & 2 barge loaded & Flood & SE \\
\hline 7 & Plan 1 & Outbound & 2 barge loaded & Ebb & SE \\
\hline 8 & Plan 1 & Outbound & 2 barge loaded & Flood & SE \\
\hline 9 & Plan 1 & Inbound & 3 barge loaded & Ebb & SE \\
\hline 10 & Plan 1 & Inbound & 3 barge loaded & Flood & SE \\
\hline 11 & Plan 1 & Outbound & 3 barge loaded & Ebb & SE \\
\hline 12 & Plan 1 & Outbound & 3 barge loaded & Flood & SE \\
\hline
\end{tabular}

\begin{tabular}{|c|c|c|c|c|c|}
\hline \multicolumn{6}{|c|}{$\begin{array}{l}\text { Table } 3 \\
\text { Chocolate Bayou Experiment Conditions }\end{array}$} \\
\hline $\begin{array}{l}\text { Experiment } \\
\text { Condition }\end{array}$ & Channel & Direction & $\begin{array}{l}\text { Tow } \\
\text { Configuration }\end{array}$ & $\begin{array}{l}\text { Current } \\
\text { Direction } \\
\end{array}$ & Wind \\
\hline 1 & Existing & Out-West & 2 barge empty & Ebb & $N E$ \\
\hline 2 & Plan 1 & In-East & 2 barge empty & Flood & SE \\
\hline 3 & Plan 1 & Out-West & 2 barge empty & Ebb & SE \\
\hline 4 & Plan 1 & Out-East & 2 barge empty & Ebb & $\overline{S E}$ \\
\hline 5 & Existing & In-East & 2 barge empty & Flood & SE \\
\hline 6 & Plan 1 & in-West & 2 barge empty & Flood & SE \\
\hline 7 & Existing & In-West & 2 barge empty & Flood & $\mathrm{NE}$ \\
\hline 8 & Plan 1 & in-West & 2 barge empty & Flood & NE \\
\hline 9 & Existing & Out-West & 2 barge empty & Ebb & SE \\
\hline 10 & Existing & Out-East & 2 barge empty & Ebb & $\mathrm{SE}$ \\
\hline 11 & Plan 1 & In-East & 2 barge empty & Flood & NE \\
\hline 12 & Existing & In-West & 2 barge empty & Flood & SE \\
\hline 13 & Existing & Out-East & 2 barge empty & $\mathrm{Ebb}$ & NE \\
\hline 14 & Plan 1 & Out-East & 2 barge empty & Ebb & NE \\
\hline 15 & Existing & In-East & 2 barge empty & Flood & NE \\
\hline 16 & Plan 1 & Out-West & 2 barge empty & $\mathrm{Ebb}$ & NE \\
\hline 17 & Existing & In-West & 2 barge loaded & Ebb & SE \\
\hline 18 & Plan 1 & In-East & 2 barge loaded & Flood & SE \\
\hline 19 & Existing & Out-East & 2 barge loaded & Ebb & SE \\
\hline 20 & Plan 1 & In-East & 3 barge empty & Flood & NE \\
\hline 21 & Plan 1 & In-West & 3 barge empty & Flood & SE \\
\hline 22 & Existing & Out-West & 2 barge loaded & Flood & SE \\
\hline 23 & Plan 1 & Out-West & 2 barge loaded & Ebb & SE \\
\hline 24 & Existing & In-East & 2 barge loaded & Flood & $S E$ \\
\hline 25 & Existing & Out-East & 2 barge loaded & Flood & SE \\
\hline 26 & Plan 1 & In-West & 2 barge loaded & Ebb & $\mathrm{SE}$ \\
\hline
\end{tabular}




\begin{tabular}{|c|c|c|c|c|c|}
\hline \multicolumn{6}{|c|}{ Table 3 (concluded) } \\
\hline 27 & Plan 1 & Out-East & 2 barge loaded & Flood & SE \\
\hline 28 & Plan 1 & Out-West & 3 barge empty & $E b b$ & SE \\
\hline 29 & Plan 1 & Out-East & 3 barge empty & Ebb & SE \\
\hline 30 & Plan 1 & In-West & 3 barge empty & Flood & $\mathrm{NE}$ \\
\hline 31 & Plan 1 & In-East & 2 barge loaded & $\mathrm{Ebb}$ & SE \\
\hline 32 & Plan 1 & Out-West & 2 barge loaded & Flood & SE \\
\hline 33 & Plan 1 & Out-West & 3 barge empty & $\mathrm{Ebb}$ & $\mathrm{NE}$ \\
\hline 34 & Plan 1 & Out-East & 2 barge loaded & Ebb & SE \\
\hline 35 & Existing & In-West & 2 barge loaded & Flood & SE \\
\hline 36 & Plan 1 & In-East & 3 barge empty & Flood & SE \\
\hline 37 & Plan 1 & In-West & 2 barge loaded & Flood & SE \\
\hline 38 & Plan 1 & Out-East & 3 barge empty & Ebb & $\mathrm{NE}$ \\
\hline 39 & Existing & In-East & 2 barge loaded & Ebb & SE \\
\hline 40 & Existing & Out-West & 2 barge loaded & Ebb & SE \\
\hline 41 & Plan 1 & Out-West & 3 barge loaded & Ebb & SE \\
\hline 42 & Plan 1 & In-West & 3 barge loaded & Ebb & SE \\
\hline 43 & Plan 1 & In-East & 3 barge loaded & Ebb & SE \\
\hline 44 & Plan 1 & In-West & 3 barge loaded & Flood & SE \\
\hline 45 & Plan 1 & Out-West & 3 barge loaded & Flood & SE \\
\hline 46 & Plan 1 & In-East & 3 barge loaded & Flood & SE \\
\hline 47 & Plan 1 & Out-East & 3 barge loaded & $\mathrm{Ebb}$ & SE \\
\hline 48 & Plan 1 & Out-East & 3 barge loaded & Flood & $\mathrm{SE}$ \\
\hline
\end{tabular}

\section{Design vessels}

Design vessels for the simulations of Galveston Causeway, Texas City Wye and Chocolate Bayou, shown in Table 4, were a 2-barge tow and towboat, $675-\mathrm{ft} \times 54-\mathrm{ft}$, and a 3-barge tow and towboat, 974-ft $\times 54-\mathrm{ft}$. Each of the vessels was evaluated in the empty and loaded condition. Loaded barges were drafting 9 -ft and empty barges were drafting 3-ft. In both conditions the push tow was drafting $7.5-\mathrm{ft}$. Comparable design vessels were used in a previous real-time navigation simulation study of Freeport Wiggles and High Island Bend.

\begin{tabular}{||c|c|c|c|c|c|c|c|c||}
\hline \multicolumn{7}{|c|}{ Table 4. Design tows for GIWW Simulation. } \\
\hline \hline \multirow{3}{*}{ Tow } & \multicolumn{7}{|c|}{$\begin{array}{c}\text { Tow Length } \\
\text { Overall } \\
\mathrm{ft}\end{array}$} \\
\cline { 2 - 10 } & No. & Length & Width & Draft & LOA & Horse Power & Length & Towboat Description \\
\hline \hline 1 & 2 & 298 & 54 & 9 & 596 & 1050 & 79 & 675 \\
\hline 2 & 2 & 298 & 54 & 3 & 596 & 1050 & 79 & 675 \\
\hline 3 & 3 & 298 & 54 & 9 & 894 & 1800 & 80 & 974 \\
\hline 4 & 3 & 298 & 54 & 3 & 894 & 1800 & 80 & 974 \\
\hline
\end{tabular}




\section{Navigation Study}

\section{Validation}

The simulation was validated with the assistance of two pilots from the Galveston area. The following information was verified and fine tuned during validation:

a. Wind effects.

b. Bank conditions.

c. Currents.

d. Engine and rudder response.

e. Visual scene and radar image of the study area.

1. Location of all aids to navigation.

2. Location of all structures visible from the vessel

Validation began by the pilots conducting real-time simulation runs through each study area with existing channel conditions and no wind or current. Vessel handling, bank effects, visual accuracy and realism were all scrutinized. Problem areas were identified, prototype data were re-examined, and the model was adjusted as needed to achieve realism. This process of experimenting and adjusting was repeated until pilots were satisfied that the simulated vessel response was similar to that of an actual vessel in the prototype. Then external forces of wind and current were added and verified by the same procedure.

\section{Experiment Scenarios and Procedure}

In order to completely analyze the proposed channels, all likely combinations of wind, current, direction of travel, and vessel loading were simulated for each of the study areas.

Experiments were conducted in a random order. This approach was designed to prevent prejudicing the results. For example, if all existing conditions were run prior to running the plans, the pilots' acquired proficiency at operating the simulator could make the plans appear to have an exaggerated effect on improving navigation. 
During each run, characteristic parameters of the ship were automatically recorded every 5 seconds. These parameters included position of the ship's center of gravity, speed, rpm of the engine, heading, drift angle, rate of turn, rudder angle, and port and starboard clearances. 


\section{Study Results}

A total of six professional pilots from the Galveston area conducted real-time simulator experiments for Galveston Causeway, Texas City Wye and Chocolate Bayou. All experiments were performed at the WES ship/tow simulator. Simulations occurred in February and March of 1998 (Table 5). Two pilots participated in each week of simulations. During each simulation run, the pilot had full

\begin{tabular}{|c|c|c|}
\hline \multicolumn{3}{|c|}{$\begin{array}{l}\text { Table 5: } \\
\text { Experiment and Validation } \\
\text { Schedule }\end{array}$} \\
\hline Activity & $\begin{array}{l}\text { Begin } \\
\text { Date } \\
\end{array}$ & End Date \\
\hline Validation & 23 Feb 98 & 27 Feb 98 \\
\hline Sim. Week 1 & 9 Mar 98 & $13 \operatorname{Mar} 98$ \\
\hline Sim. Week 2 & $16 \operatorname{Mar} 98$ & $20 \operatorname{Mar} 98$ \\
\hline Sim. Week 3 & $23 \operatorname{Mar} 98$ & $27 \operatorname{Mar} 98$ \\
\hline
\end{tabular}
control over the vessel's rudder and engines. Track plots of real-time simulations conducted at the WES ship/tow simulator are presented in Plates 1-76.

\section{Track Plot Analysis}

\section{Galveston Causeway}

\section{Heading East}

Loaded Barges, Ebb Tide, Wind from the Southeast. Composite plots of loaded barges heading east on the GIWW toward the Galveston Causeway with ebb tide currents and the wind out of the southeast are shown in Plates 1 - 4. The composite plot for a 2-barge tow with existing channel conditions (Plate 1) shows two out of six pilots left the channel limits on the south side of the channel during the approach to the bridge. Plate 2 is a composite plot for a 3-barge tow approaching the bridge with Plan 1 channel conditions. Four pilots attempted this condition. All four of the pilots left the channel on the north side when entering the bend which could be an indication of a bad starting position in the simulation. All four of the pilots stayed within the channel limits for the remainder of the approach which is an improvement compared to existing conditions. Plates 3 and 4 are composite plots of 2 and 3barge tows approaching the causeway with Plan 2 channel conditions. Plate 3 shows that the two pilots that attempted this condition left the north side of the channel on the inside of the bend. Neither of these pilots attempted to use the dolphins during the approach. Plate 4 shows that out of the four pilots that attempted the approach with 3-barges, three of them left the south side of the channel in the bend and two of them hit the dolphins. The fourth pilot made it through the entire approach without leaving the channel or using the dolphins. 
Loaded Barges, Flood Tide, Wind from the Southeast. Composite plots of loaded barges heading east on the GIWW toward the Galveston Causeway with flood tide currents and wind out of the southeast are shown in Plates $5-7$. The composite plot for a 2-barge tow with existing channel conditions (Plate 5) shows that out of the four pilots that attempted the approach, none were able to stay within the channel limits for the entire approach. Because no pilots were successful with a 2-barges no attempt was made to navigate the reach with a 3barge tow. Plate 6 is a composite plot showing a 3-barge tow approaching the causeway with Plan 1 channel conditions. Both pilots were successful making the approach, but one of them came very close to the north side of the channel, corrected his course and came very close to the south side of the channel. Plate 7 is a composite plot showing a 3-barge tow approaching the causeway with Plan 2 channel conditions. Two pilots attempted this approach, both were successful and neither one used the proposed dolphins.

Empty Barges, Ebb Tide, Wind from the Southeast. Composite plots of empty barges heading east on the GIWW toward the Galveston Causeway with ebb tide currents, and wind out of the southeast are shown in Plates $8-12$. In the analysis of empty barge track plots it should be noted that it is possible for the bow of the tow to leave the channel limits without grounding. However, the stern of the vessel must stay within the channel limits. The composite plot for a 2-barge tow with existing channel conditions (Plate 8) shows that all six of the pilots attempting the approach left the channel limits. Plate 9 shows composite plots of a 2-barge tow approaching the causeway with Plan 1 channel conditions. All six of the pilots that attempted the approach left the channel limits. One of the pilots left the channel on the north side of the channel and the other five left the channel on the south side. Plate 10 shows composite plots of a 3-barge tow approaching the causeway with Plan 1 channel conditions. As with the 2-barge tow, all of the pilots left the channel. Plate 11 is a composite plot showing a 2barge tow approaching the causeway with Plan 2 channel conditions. Out of the six pilots that attempted the approach four left the channel limits on the south side of the channel and two left the channel on the north side. Plate 12 is a composite plot showing a 3-barge tow approaching the causeway with Plan 2 channel conditions. Five pilots attempted the approach. Out of the five pilots, one stayed within the channel limits for the majority of the run. However, as the tow approached the causeway, the dolphins were an obstacle rather than an aid as the tow tried to maneuver into the fender system. The other pilots attempting the approach left the channel limits on the south side of the channel.

Empty Barges, Ebb Tide, Wind from the Northeast. Composite plots of empty barges heading east on the GIWW toward the Galveston Causeway with ebb tide currents, and wind out of the northeast are shown in Plates $13-17$. The composite plot for a 2-barge tow approaching the causeway with existing channel conditions is shown in Plate 13. Out of the six pilots that attempted the approach, five left the channel limits on the south side of the channel. The other pilot ran out of the channel on the north side. Plate 14 shows composite plots of 
a 2-barge tow approaching the causeway with Plan 1 channel conditions. Out of the six pilots that attempted the approach, four ran out of the channel on the south side while making the bend. Two of the pilots ran out of the channel on the north side in the straight section just before the causeway and four of the pilots made it through the straight section without leaving the channel limits. Plate 15 shows composite plots of a 3-barge tow approaching the causeway with Plan 1 conditions. All six of the pilots that attempted the approach ran out of the channel on the south side while making the bend. However, five out of the six pilots stayed in the channel after making the bend and the sixth pilot only slightly left the channel on the north side. Plate 16 shows composite plots of a 2-barge tow approaching the causeway with Plan 2 channel conditions. Five pilots attempted the approach, and three out of the five were able to transit the reach successfully. Of the other two pilots, one ran out of the south side of the channel and one ran out of the north side. However, none of the pilots used the dolphins as a navigation aid. Plate 17 shows composite plots of a 3-barge tow approaching the causeway with Plan 2 channel conditions. All six of the pilots that attempted the approach ran out of the channel on the south side in the bend. After maneuvering through the bend, all of the pilots were able to stay within the channel limits and none of them used the dolphins as a navigation aid.

Empty Barges, Flood Tide, Wind from the Southeast. With this condition one pilot attempted the approach with a 2-barge tow and the existing channel condition (Plate 18) and one pilot attempted the approach with a 2-barge tow and the channel representing the Plan 2 channel condition (Plate 19). With the existing channel condition the pilot was able to stay within the channel limits for the majority of the run, but a lot of maneuvering was required. With the Plan 2 channel condition the pilot left the channel on the south side during the approach to the bridge. The pilot attempting the Plan 2 channel condition did not use the dolphins, and they appeared to be more of an obstacle than a navigation aid.

\section{Heading West}

Loaded Barges, Ebb Tide, Wind from the Southeast. Composite plots of loaded barges heading west on the GIWW toward Galveston Causeway with ebb tide currents, and wind out of the southeast are shown in Plates 20 - 22. Plate 20 shows a composite plot of a 2-barge tow approaching the causeway with existing channel conditions. With this condition, two pilots attempted the approach and both were successful. Plate 21 is a composite plot showing a 3-barge tow approaching the causeway with Plan 1 channel conditions. Out of the two pilots that attempted this condition, one was successful and the other one left the channel on the south side while making the bend just before approaching the causeway. Neither pilot attempted to use the dolphins. Plate 22 is a composite plot showing a 3-barge tow approaching the causeway with Plan 2 channel conditions. The two pilots that attempted this approach were successful. 
Loaded Barges, Flood Tide, Wind from the Southeast. Composite plots of loaded barges heading west on the GIWW toward Galveston Causeway with flood tide currents, and wind out of the southeast are shown in Plates $23-26$. Plate 23 is a composite plot showing a 2-barge tow approaching the causeway with existing channel conditions. Out of the six pilots that attempted the approach, three left the channel limits on the north side just before the causeway. One of the other three came very close to the north side of the channel and the other two pilots were successful. Plate 24 is a composite plot showing a 3-barge tow approaching the causeway with Plan 1 channel conditions. Five out of the six pilots attempting the approach left the south side of the channel in the bend. Three of the pilots entered the fender system at the causeway too far toward the north side and two of the pilots entered the fender system too far toward the south side. The sixth pilot ended his run before entering the causeway fender system. Plate 25 shows the track plot of the only pilot that attempted the approach with a 2-barge tow and Plan 2 channel conditions. The pilot left the channel on the south side in the bend and entered the fender system too far to the south side. Plate 26 is a composite plot of a 3-barge tow approaching the causeway with Plan 2 channel conditions. Three of the six pilots that attempted this approach left the south side of the channel in the bend. Five of the six pilots entered the causeway fender system too far to the north.

Empty Barges, Flood Tide, Wind from the Southeast. Composite plots of empty barges heading west on the GIWW toward Galveston Causeway with flood tide currents, and wind out of the southeast are shown in Plates 27 - 30 . Plate 27 is a composite plot showing a 2-barge tow approaching the causeway with existing channel conditions. Five out of the six pilots that attempted the approach ran out of the north side of the channel. The other pilot left the channel limits on the south side. None of the pilots were able to successfully enter the causeway fender system. Plate 28 is a composite plot of a 2-barge tow approaching the causeway with Plan 1 channel conditions. Of the six pilots that attempted the approach, three chose to use the dolphins. All three of these pilots left the north side of the channel during the approach and two of the three approached the dolphins too fast. The third pilot was able to slow his speed but to do it he had to turn his vessel completely sideways in the channel. All three of the pilots that did not use the dolphins left the north side of the channel during the approach to the bridge. Plate 29 is a composite plot of a 3-barge tow approaching the causeway with Plan 1 conditions. All five of the pilots that attempted the approach left the channel limits on the north side of the channel. One of the pilots attempted to land on the proposed dolphins but the speed of the vessel as it approached the dolphin was too high and most likely would have resulted in damage to the vessel and/or dolphin. Three of the pilots chose not to use the dolphins which resulted in the dolphins being more of an obstacle than an aid. Plate 29 is a composite plot showing a 2-barge tow approaching the causeway with Plan 2 channel conditions. All five of the pilots that attempted the approach left the channel on the north side and none were successful making it into the fender system. Plate 30 is a composite plot showing a 3-barge tow approaching the causeway with Plan 2 channel conditions. All five pilots that attempted the approach left the channel limits on the north side and none were 
successful making it into the fender system.

Empty Barges, Flood Tide, Wind from the Northeast. Composite plots of empty barges heading west on the GIWW toward Galveston Causeway with flood tide currents, and wind out of the northeast are shown in Plates 32 36. Plate 32 is a composite plot showing a 2-barge tow approaching the causeway with existing channel conditions. All six pilots that attempted the approach left the channel limits on the north side immediately after making it through the bend. Plate 33 is a composite plot showing a 2-barge tow approaching the causeway with Plan 1 channel conditions. Out of the six pilots that attempted the approach, two tried to use the dolphins as navigation aids. However, due to the angle of the line of dolphins relative to the angle of the wind, the pilots were not able to approach the dolphins at a slow enough speed to prevent damage to the vessel and/or dolphin. The other four pilots made an approach very similar to the approach now being made with existing conditions except they were able to stay in the channel better. All four pilots making the normal approach ended up too close to the north side of the fender system at the causeway. Plate 34 is a composite plot showing a 3-barge tow approaching the causeway with Plan 1 channel conditions. Out of the six pilots that attempted the approach, two tried to use the dolphins. Both of the pilots that attempted to use the dolphins left the channel on the north side. The other four pilots left the channel limits on the south side of the channel. Plate 35 is a composite plot showing a 2-barge tow approaching the causeway with Plan 2 channel conditions. Out of the six pilots that attempted the approach, three were successful and the other three only slightly left the channel limits on the north side of the channel. Plate 36 is a composite plot showing a 3-barge tow approaching the causeway with Plan 2 channel conditions. Out of the six pilots that attempted the approach, three left the channel limits on the south side, one left the channel limits on the north side and two were successful.

\section{Chocolate Bayou}

\section{Heading East, Inbound to Chocolate Bayou.}

Loaded Barges, Ebb Tide, Wind from the Southeast. Composite plots of loaded barges heading east on the GIWW and turning inbound to Chocolate Bayou are shown in Plates 37 - 39. The composite plot for a 2-barge tow with existing channel conditions (Plate 37) shows that out of the two pilots attempted none were able to turn into Chocolate Bayou. One reason for the pilots leaving the channel is that the existing channel is poorly marked. Both pilots commented that even though the model was marked like the prototype, it was harder to determine where the channel was in the model. The 2-barge tows in the proposed condition (Plate 38) left the GIWW on the south side when beginning the turn but were able to complete the turn. The 3-barge tows in the proposed conditions (Plate 39) also left the southern side of the GIWW when starting the turn. The 3-barge tows were able to successfully complete the turn. 
Empty Barges, Flood Tide, Wind from the Southeast. A composite plot of empty barges heading east on the GIWW and turning inbound to Chocolate Bayou are shown in Plates 40 - 41. Only 2-barge tows were used for this scenario, no 3-barge runs were conducted. Several of the six runs conducted in the existing channel (Plate 40) went outside of the channel on both the east and west sides. Again this is due to the channel being poorly marked. The runs in the proposed channel (Plate 41) showed an improvement over the existing conditions.

Empty Barges, Flood Tide, Wind from the Northeast. Composite plots of empty barges heading east on the GIWW and turning inbound to Chocolate Bayou are shown in Plates 42 - 43. Only 2-barge tows were used for this scenario, no 3-barge runs were conducted. Several of the five runs conducted in the existing channel (Plate 42) went outside of the channel on both the east and west sides. The runs in the proposed channel (Plate 43) showed an improvement over the existing conditions.

Loaded Barges, Flood Tide, Wind from the Southeast A composite plot of loaded barges heading east on the GIWW and turning inbound through the proposed turn into Chocolate Bayou is shown in Plate 44. Both runs were successful. No existing condition runs were conducted for this scenario.

Loaded Barges, Flood Tide, Wind from the Northeast. One run of loaded barges heading east on the GIWW and turning inbound through the proposed turn to Chocolate Bayou is shown in Plate 45. The run was successful. No existing condition runs were conducted for this scenario.

\section{Heading West, Outbound from Chocolate Bayou to GIWW}

Empty Barges, Ebb Tide, Wind from the Southeast. Composite plots of empty barges heading outbound from Chocolate Bayou and turning west onto the GIWW are shown in Plates $46-47$. Five transits in the existing channel (Plate 46) left the channel on both the east and west sides. One run in the plan channel (Plate 47) left the channel on the west side when entering the turn.

Loaded Barges, Ebb Tide, Wind from the Southeast. A composite plot of loaded barges heading outbound from Chocolate Bayou and turning west onto the GIWW is shown in Plate 48. Two of four runs in the plan channel left the channel on the west side when entering the turn. No existing condition runs were conducted for this scenario.

Empty Barges, Ebb Tide, Wind from the Northeast. Composite plots of empty barges heading outbound from Chocolate Bayou and turning west onto the GIWW are shown in Plates $49-50$. Four transits in the existing channel (Plate 49) left the channel on both the east and west sides. Although several runs in the proposed channel (Plate 50) crossed the channel limits, the runs were successful and showed improvement over existing conditions. 
Loaded Barges, Ebb Tide, Wind from the Northeast. One run of loaded barges heading outbound from Chocolate Bayou and turning west onto the GIWW with ebb tide and wind from the northeast was conducted. That run, in the existing channel, is shown in Plate 51. The tow went several hundred feet outside of the channel on the east while making the turn.

Loaded Barges, Flood Tide, Wind from the Southeast. Composite plots of loaded barges heading outbound from Chocolate Bayou and turning west onto the GIWW are shown in Plates 52 - 53. One tow in the existing channel (Plate 52) was unable to make the turn and another went nearly $200 \mathrm{ft}$ outside of the channel on the east side. The other two existing condition runs were able to complete the turn, but all crossed the channel limits. The 3-barge tow runs in the proposed channel (Plate 53) crossed the channel limit at the end of the turn into the GIWW. The runs were successful and showed improvement over existing conditions.

\section{Heading West, Inbound to Chocolate Bayou}

Loaded Barges, Ebb Tide, Wind from the Southeast. A composite plot of loaded barges heading west on the GIWW and turning inbound into Chocolate Bayou is shown in Plate 54. Six simulations of this scenario were conducted for existing conditions. Although some of the barges crossed the channel limits, the pilots were able to successfully complete the run.

Empty Barges, Flood Tide, Wind from the Northeast. Composite plots of empty barges heading west on the GIWW and turning inbound into Chocolate Bayou are shown in Plates 55 - 56. Runs in the existing channel (Plate 55) left the channel limits; but the pilots were able to complete the turn. One pilot in the proposed channel (Plate 56) turned too soon, losing control of his tug and invalidating his run. However, the remaining transits show an improvement over existing conditions.

Loaded Barges, Flood Tide, Wind from the Southeast. A composite plot of loaded barges heading west on the GIWW and turning inbound into Chocolate Bayou is shown in Plate 57. The two transits in the existing channel left the channel; but the pilots were able to complete the turn.

Empty Barges, Flood Tide, Wind from the Southeast. A composite plot of empty barges heading west on the GIWW and turning inbound into Chocolate Bayou is shown in Plate 58. One pilot in the proposed channel turned too soon and lost control of his tug. The remaining five transits show an improvement over existing conditions.

\section{Heading East, Outbound from Chocolate Bayou}

Empty Barges, Ebb Tide, Wind from the Southeast. Composite plots of empty barges leaving Chocolate Bayou and turning east onto the GIWW are shown in Plates 59 - 60. The six pilots for the existing condition (Plate 59) were 
able to complete the transit although all runs left the authorized channel during the turn. One pilot in the proposed condition (Plate 60) lost control of his tow just north of the turn, but recovered and completed the transit.

Loaded Barges, Ebb Tide, Wind from the Southeast. A composite plot of loaded barges leaving Chocolate Bayou and turning east onto the GIWW is shown in Plate 61. Simulations of this scenario were conducted for existing conditions only. One pilot lost control of his barge while making the turn. The three remaining tows completed the transit.

Empty Barges, Ebb Tide, Wind from the Northeast. A composite plot of empty barges leaving Chocolate Bayou and turning east onto the GIWW is shown in Plate 62. Simulations of this scenario were conducted for existing conditions only. All six tows left the channel while making the turn; but completed the run.

Loaded Barges, Flood Tide, Wind from the Southeast. A composite plot of loaded barges leaving Chocolate Bayou and turning east onto the GIWW is shown in Plate 63. Simulations of this scenario were conducted for existing conditions only. Both tows left the channel limits while making the turn; however, they were able to complete the run.

Empty Barges, Ebb Tide, Wind from the Northeast. A composite plot of empty barges leaving Chocolate Bayou and turning east onto the GIWW is shown in Plate 64. Simulations of this scenario were conducted for proposed conditions only. Three of the tows stayed within the channel while making the turn; however, two crossed the southern channel limit just after entering the GIWW.

\section{Texas City Wye}

Inbound, Ebb Tide, Loaded Barges with wind from the Southeast. The plots of inbound tows pushing loaded barges with ebb tide and a southeast wind are shown in Plates 65 -67. None of the simulations conducted with existing channel conditions and 2-barge tows (Plate 65) were successful. Only one of these runs even made it into the Texas City Channel. That run left the authorized channel on the east just prior to entering the Texas City Channel. One of the 2-barge tow simulations conducted in the proposed channel (Plate 66) left the Texas City Channel on the east side. The pilot of that run was the last one to begin his turn. He was running on the side slope of the $40 \mathrm{ft}$ deep ship channel and did not run aground. Two of the runs crossed the GIWW channel limits on the north side as they were entering the widener. All of the 3-barge tow runs in the Plan 1 channel (Plate 67) successfully turned into the Texas City Channel. As with the 2-barge runs in the Plan 1 channel, several of the runs crossed the GIWW channel limits when entering the widener. 
Inbound, Flood Tide, Loaded Barges with wind from the Southeast. The plots of inbound tows pushing loaded barges with flood tide and a southeast wind are shown in Plates $68-70$. Three of the six runs conducted in the existing channel (Plate 68) were able to turn into the Texas City Channel. However, all of the runs crossed the channel limits at least once while making the turn from the GIWW to the Texas City Channel. One of the 2-barge tow simulations conducted in the proposed channel (Plate 69) left the Texas City Channel on the east side. The pilot of that run did not go as far out of the channel as the 2-barge tow that left the proposed channel during the ebb tide simulations. As with the ebb tide run, the pilot to leave the Texas City Channel was the last one to begin his turn. He was running on the side slope of the $40 \mathrm{ft}$ deep ship channel and did not run aground. Several of the pilots left the west side of the GIWW channel limits while entering the proposed widener. Two of the 3-barge runs in the proposed channel (Plate 70) ended when the pilots ran aground on the west side of the widener. This occurred because they began their turn too soon. One of the two pilots that ran aground repeated the simulation successfully. One of the runs that was able to enter the Texas City Channel left the channel on the east side.

Outbound, Ebb Tide, Loaded Barges with wind from the Southeast. The plots of outbound tows pushing loaded barges with ebb tide and a southeast wind are shown in Plates 71 - 73. All of the runs in the existing channel (Plate 71) were able to complete the turn and head west on the GIWW. However, all of the runs crossed the channel limits at least once while making the turn from the Texas City Channel to the GIWW. All of the 2-barge tow simulations conducted in the proposed channel (Plate 72) were able to complete the turn. Several of the runs left the Texas City Channel on the east side prior to entering the widener. One of these runs left the channel by $110 \mathrm{ft}$ and most likely would have grounded. Several of the runs crossed the west side of the GIWW channel limits when completing the turn through the widener. All of the 3-barge tow simulations conducted in the proposed channel (Plate 73) were able to complete the turn. All of these runs left the Texas City Channel by as much as $80 \mathrm{ft}$ on the east side prior to entering the widener. Several of the runs crossed the west side of the GIWW channel limits when completing the turn through the widener.

Outbound, Flood Tide, Loaded Barges with wind from the Southeast. The plots of outbound tows pushing loaded barges with flood tide and a southeast wind are shown in Plates 74 - 76. All of the runs in the existing channel (Plate 74) were able to complete the turn and head west on the GIWW. However, all of the runs crossed the channel limits at least once while making the turn from the Texas City Channel to the GIWW. All of the 2-barge tow simulations conducted in the proposed channel (Plate 75) were able to complete the turn. Several of the runs left the Texas City Channel on the east side prior to entering the widener. One of these runs left the channel by $100 \mathrm{ft}$ and most likely would have grounded. Several of the runs crossed the west side of the GIWW channel limits when exiting the widener. All of the 3-barge tow simulations conducted in the proposed channel (Plate 76) were able to complete the turn. Two of these runs left the Texas City Channel on the east side prior to 
entering the widener. One just crossed the $40 \mathrm{ft}$ deep channel limits and the other left the channel by nearly $110 \mathrm{ft}$. Several of the runs crossed the west side of the GIWW channel limits when completing the turn through the widener.

\section{Final Questionnaire}

After finishing all simulation runs, pilots completed a final questionnaire (Figures $10-23$ ) to give their opinions on the project as well as on the simulation. Some of the comments made by the pilots on the project follow:

\section{GALVESTON CAUSEWAY FINAL DEBRIEFING QUESTIONNAIRE}

Based on the week of simulation you have just completed, please put an $\mathrm{x}$ on the scale in answer to the question. Please use the comments section to explain your choices and be as specific as possible. Use the back of the form if necessary.

1. Comparing Plan 1 to the existing channel, rate the safety improvement for Plan

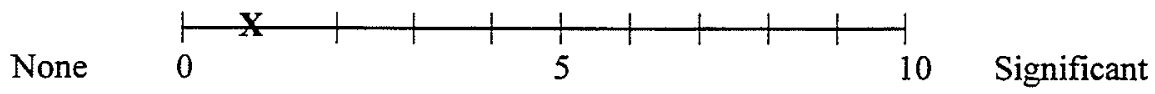

2. Comparing Plan 2 to the existing channel, rate the safety improvement for Plan 2 .

None

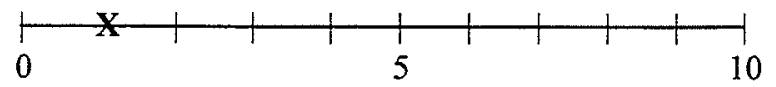

Significant

3. Rate the plan that you feel is the most safe choosing 0 as no difference:

Plan 1

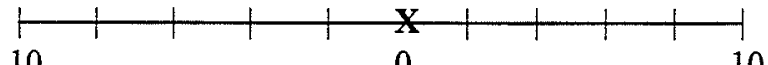

Plan 2

4. Rate the following simulator models/effects for realism:

Visuals:

Low

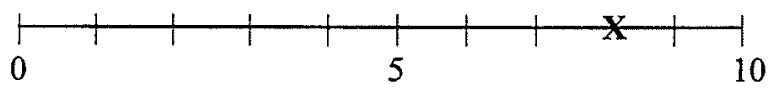

High

Radar:

Low

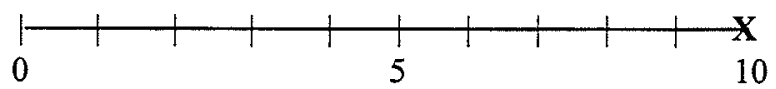

High

Figure 10. Final Questionnaire: Galveston Causeway, Pilot 1 (Continued) 


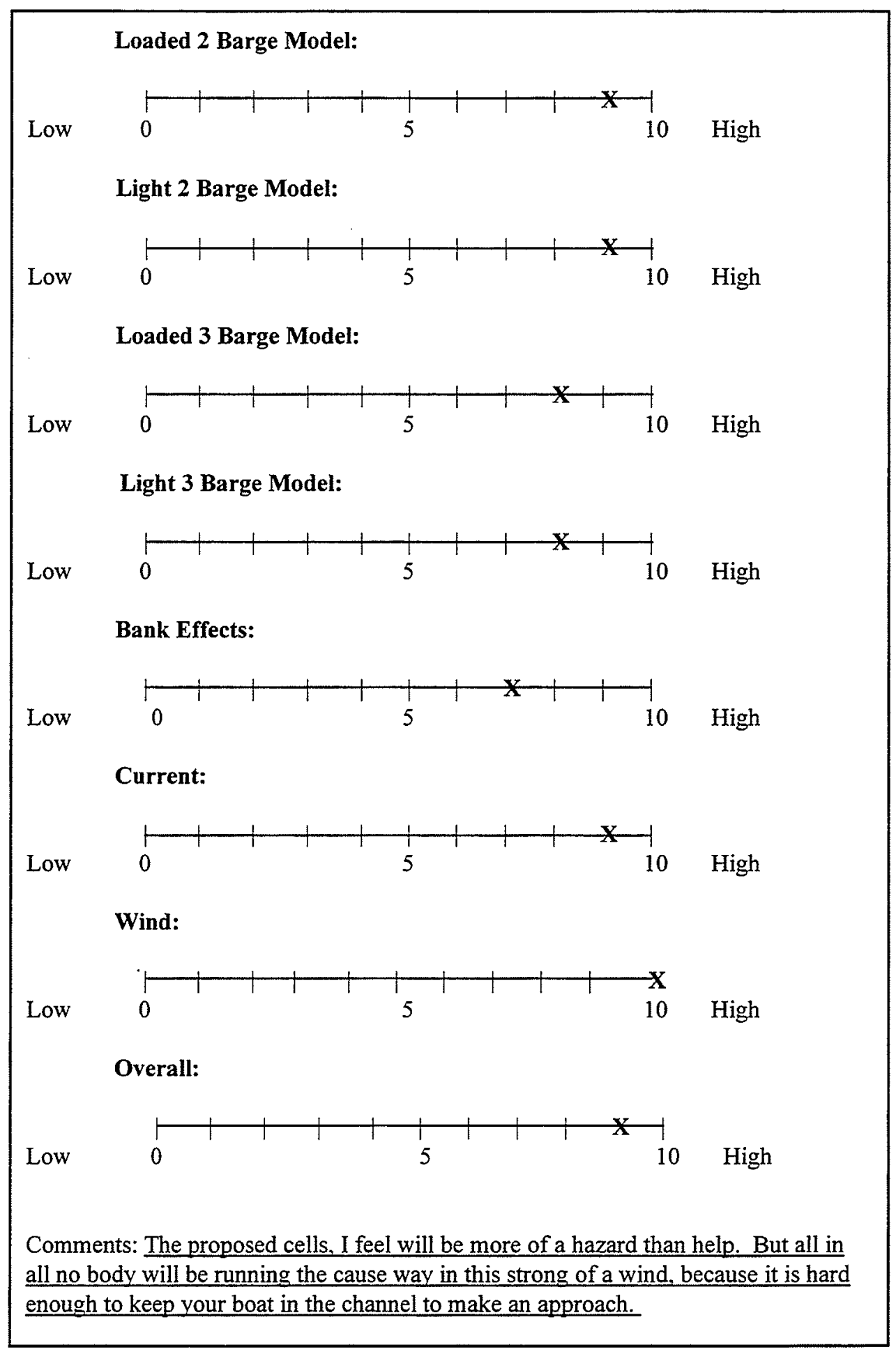

Figure 10. (Concluded) 


\section{CHOCOLATE BAYOU \\ FINAL DEBRIEFING QUESTIONNAIRE}

1. Comparing Plan 1 to the existing channel, rate the safety improvement for Plan 1.

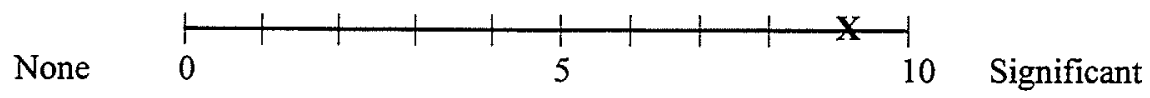

2. Rate the following simulator models/effects for realism:

Visuals:

Low

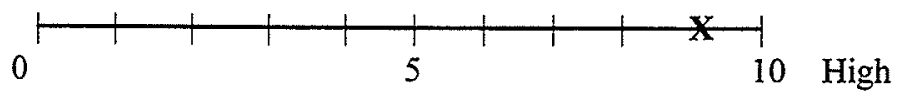

Radar:

Low

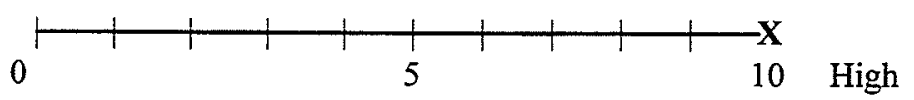

Loaded 2 Barge Model:

Low

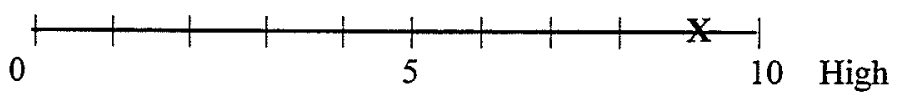

Light 2 Barge Model:

Low

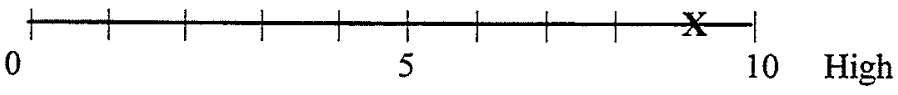

Loaded 3 Barge Model:

Low

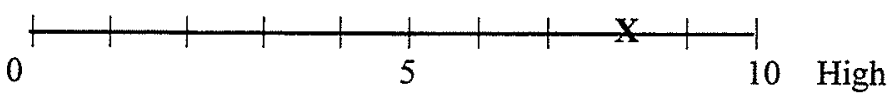

Light 3 Barge Model:

Low

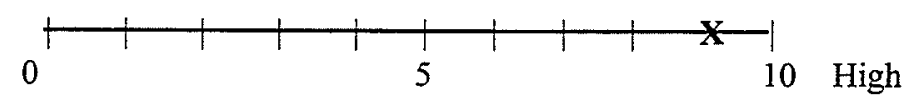

Bank Effects:

Low

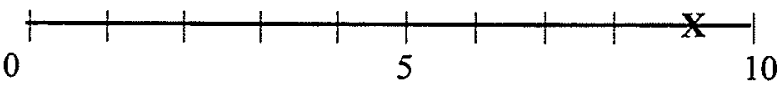

High

Figure 11. Final Questionnaire: Chocolate Bayou, Pilot 1 (Continued) 


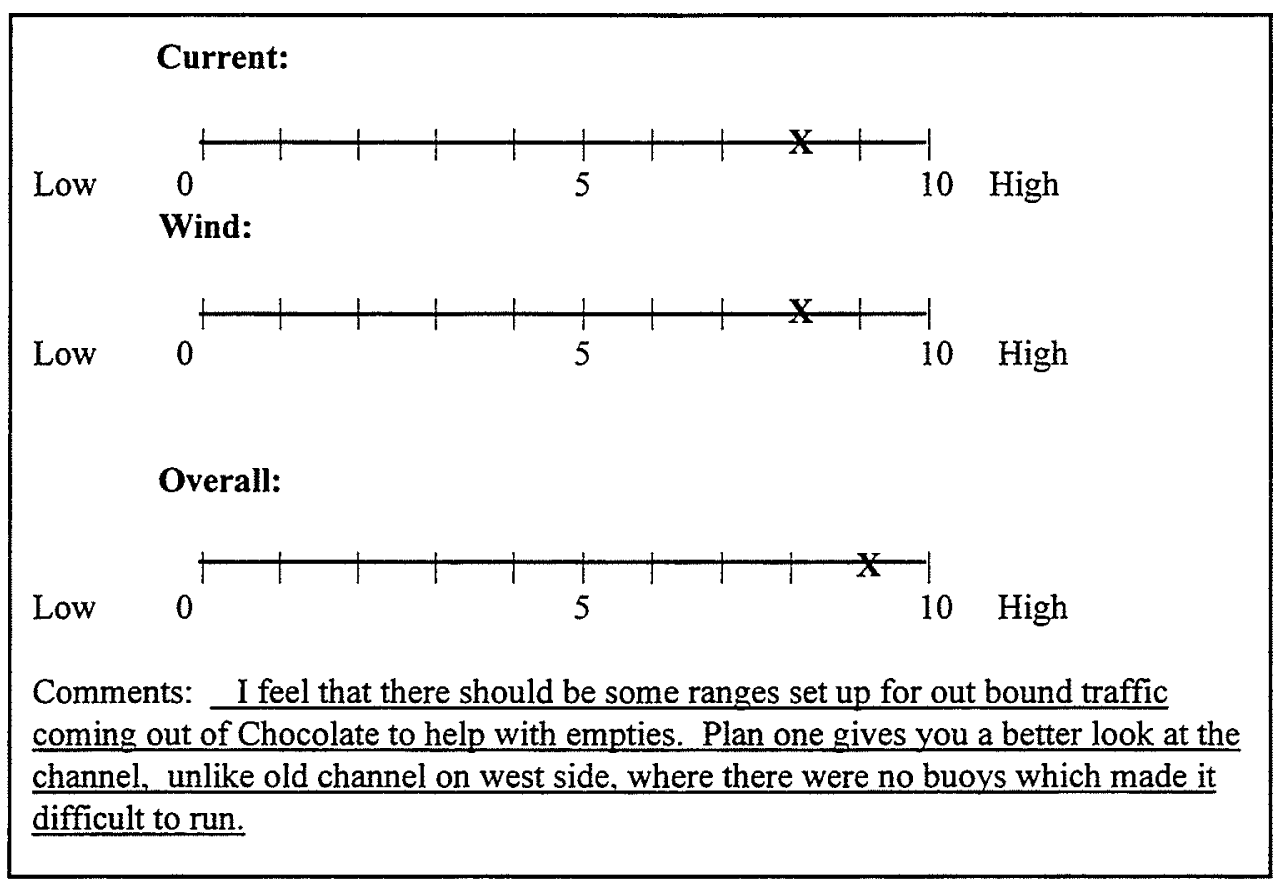

Figure 11. (Concluded)

\section{TEXAS CITY WYE FINAL DEBRIEFING QUESTIONNAIRE}

1. Comparing Plan 1 to the existing channel, rate the safety improvement for Plan 1.

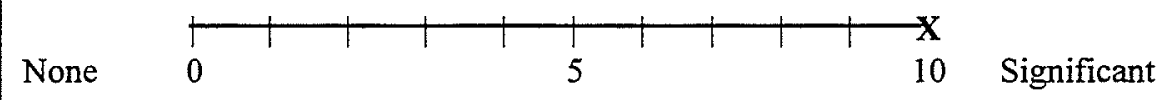

2. Rate the following simulator models/effects for realism:

Visuals:

Low

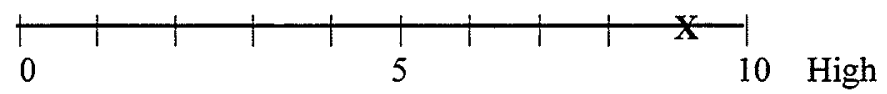

Radar:

Low

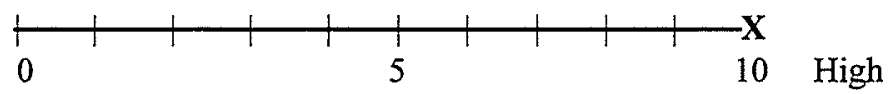

Loaded 2 Barge Model:

Low

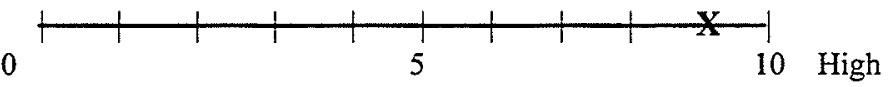

Figure 12. Final Questionnaire: Texas City Wye, Pilot 1 (Continued) 


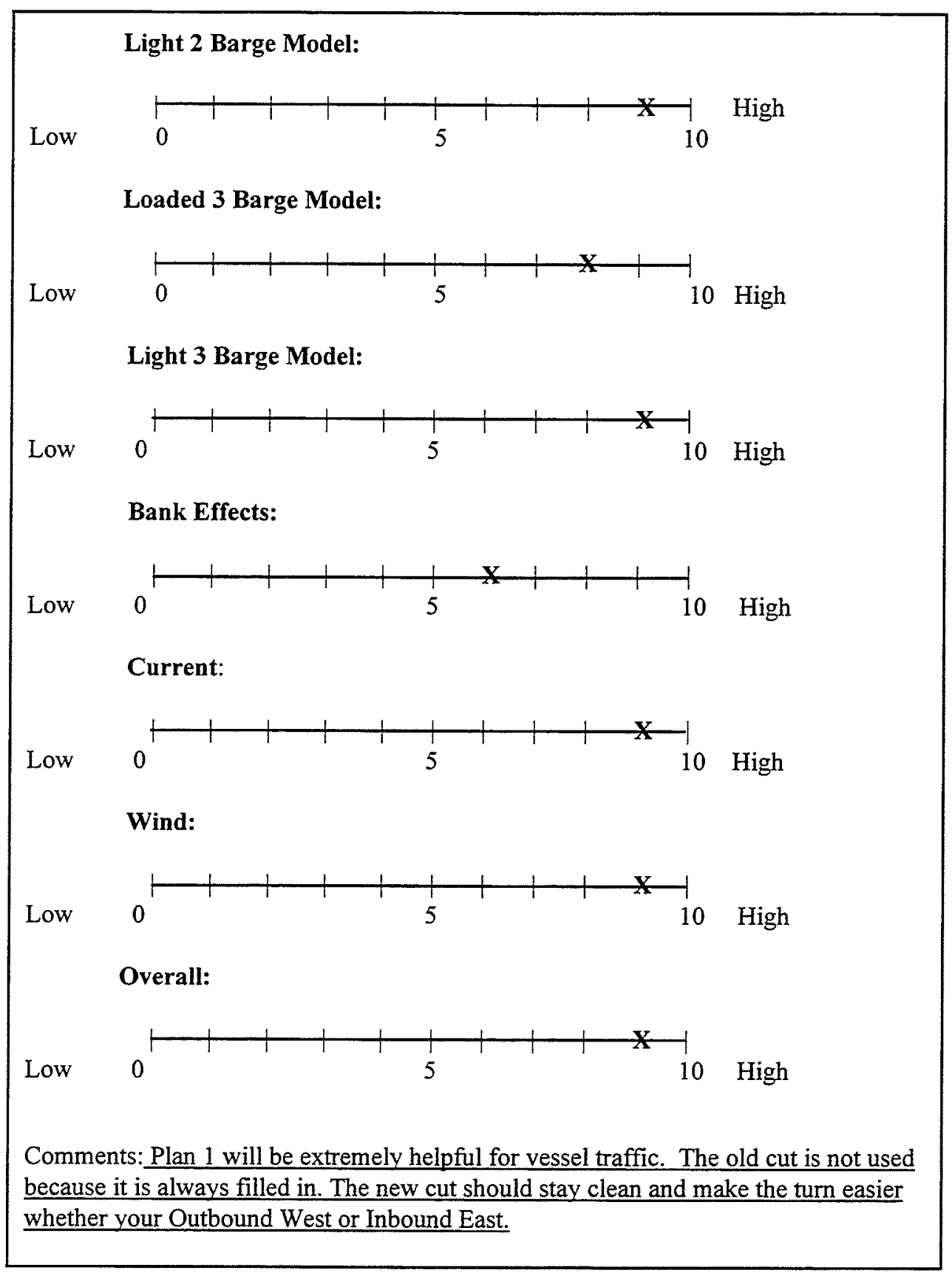

Figure 12. (Concluded) 


\section{GALVESTON CAUSEWAY FINAL DEBRIEFING OUESTIONNAIRE}

Based on the week of simulation you have just completed, please put an $\mathrm{x}$ on the scale in answer to the question. Please use the comments section to explain your choices and be as specific as possible. Use the back of the form if necessary.

1. Comparing Plan 1 to the existing channel, rate the safety improvement for Plan

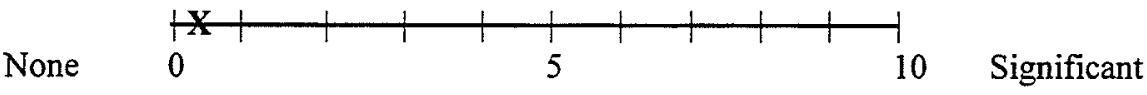

2. Comparing Plan 2 to the existing channel, rate the safety improvement for Plan 2.

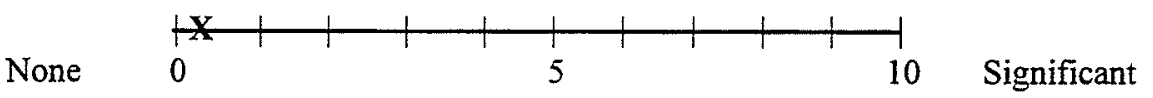

3. Rate the plan that you feel is the most safe choosing 0 as no difference:

Plan 1

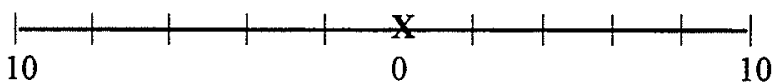

Plan 2

4. Rate the following simulator models/effects for realism:

Visuals:

Low

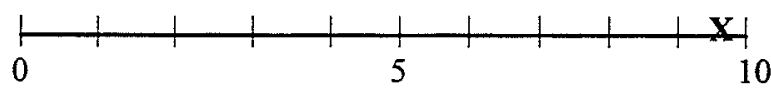

High

Radar:

Low

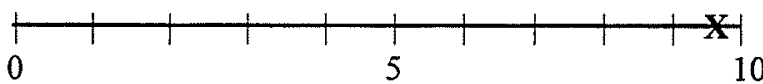

High

Loaded 2 Barge Model:

Low

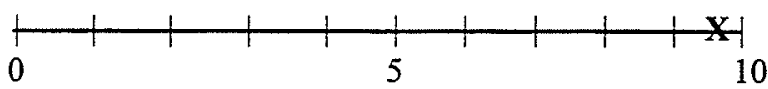

High

Light 2 Barge Model:

Low

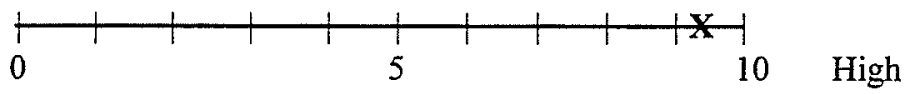

Loaded 3 Barge Model:

Low

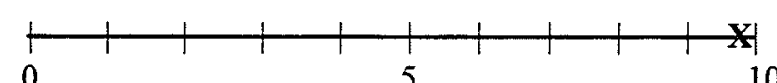

High

Figure 13. Final Questionnaire: Galveston Causeway, Pilot 2 (Continued) 


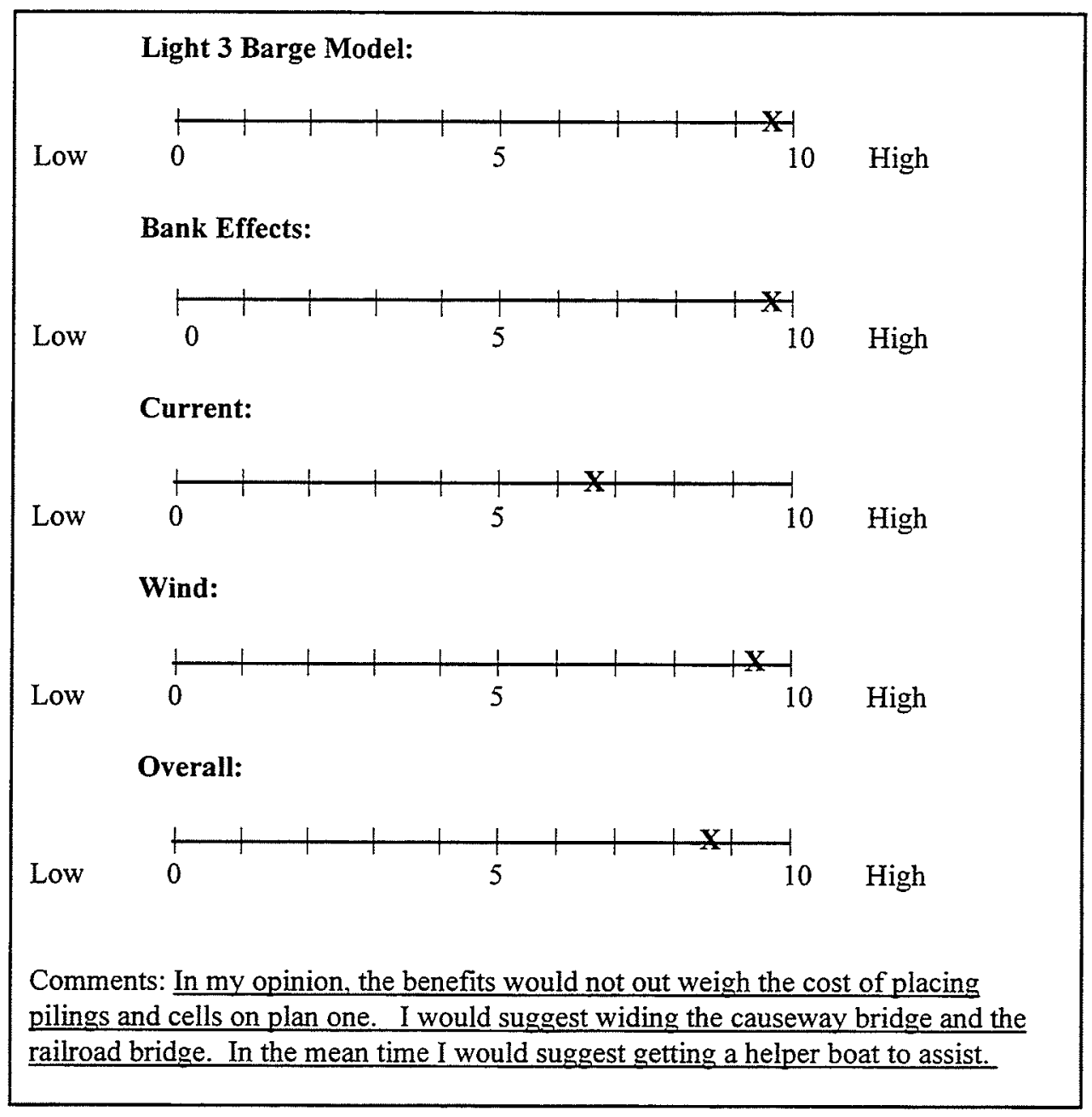

Figure 13. (Concluded)

\section{CHOCOLATE BAYOU FINAL DEBRIEFING OUESTIONNAIRE}

1. Comparing Plan 1 to the existing channel, rate the safety improvement for Plan 1 .

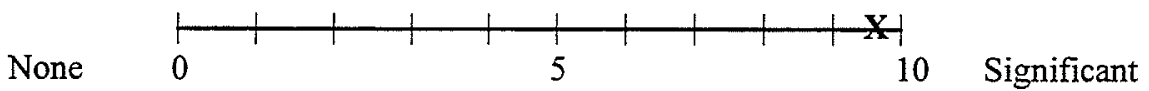

2. Rate the following simulator models/effects for realism:

Visuals:

Low

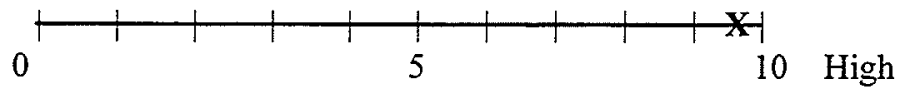

Figure 14. Final Questionnaire: Chocolate Bayou, Pilot 2 (Continued) 


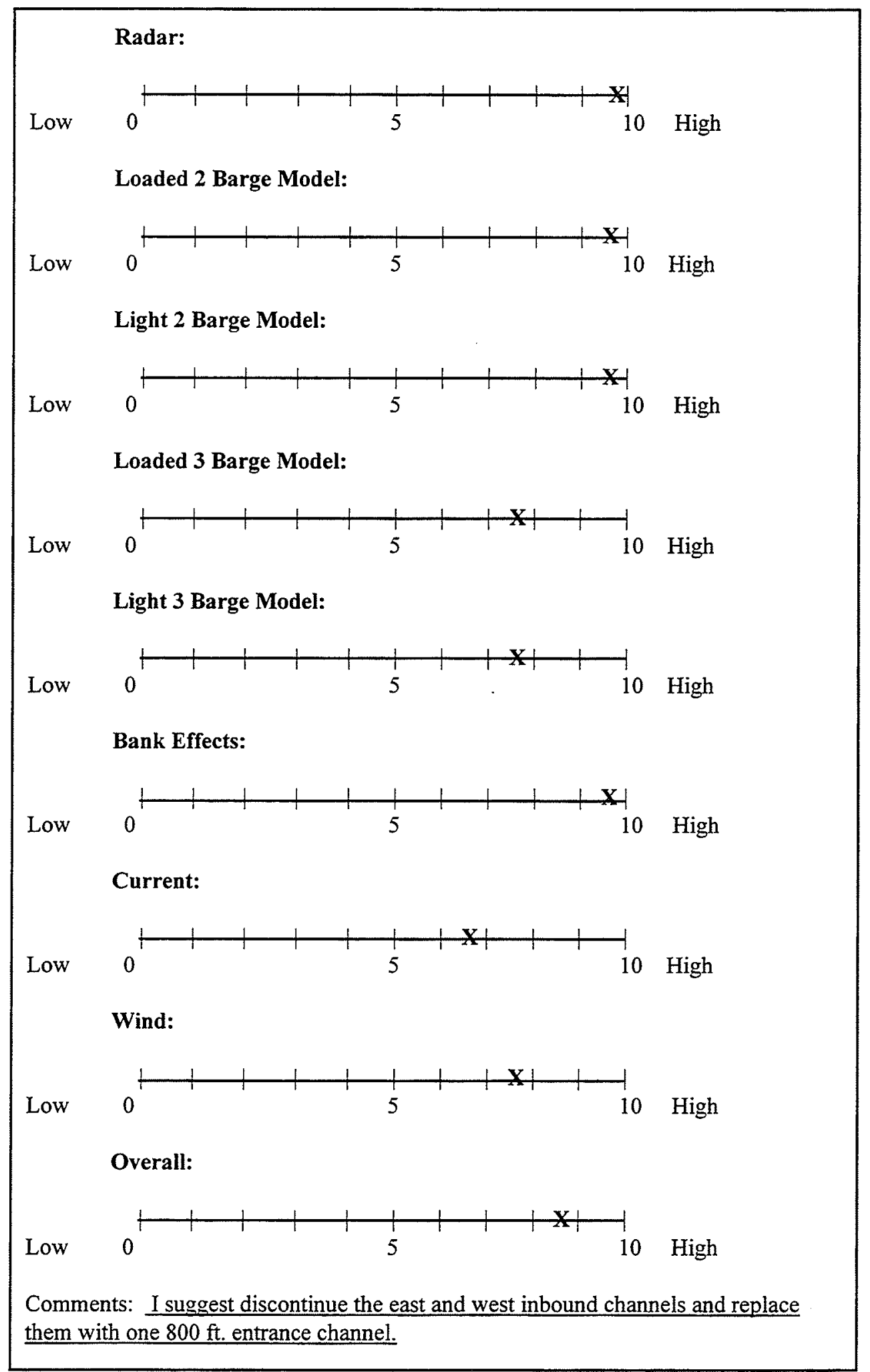

Figure 14. (Conciuded) 


\section{TEXAS CITY WYE FINAL DEBRIEFING QUESTIONNAIRE}

1. Comparing Plan 1 to the existing channel, rate the safety improvement for Plan 1.

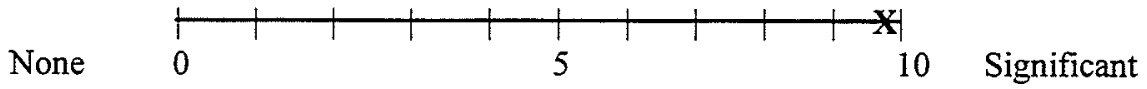

2. Rate the following simulator models/effects for realism:

Visuals:

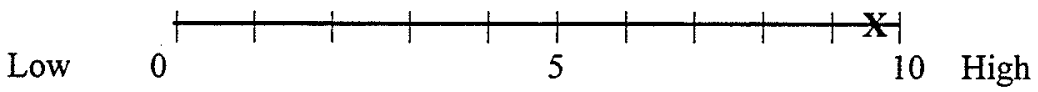

Radar:

Low

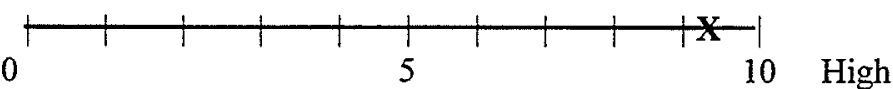

Loaded 2 Barge Model:

Low

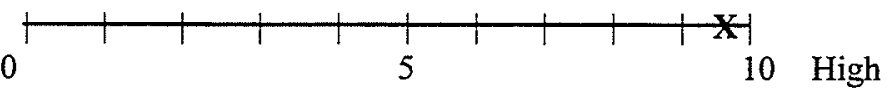

Light 2 Barge Model:

Low

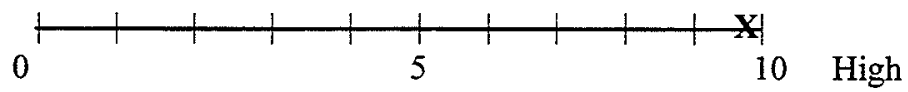

Loaded 3 Barge Model:

Low

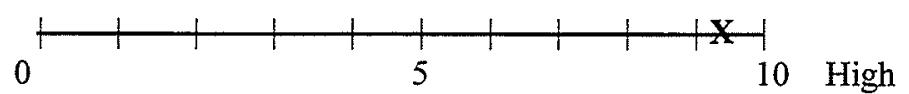

Light 3 Barge Model:

Low

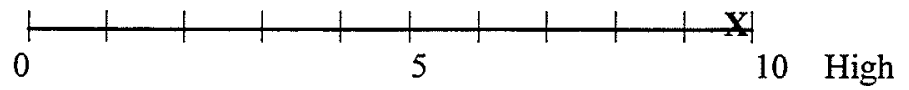

Bank Effects:

Low

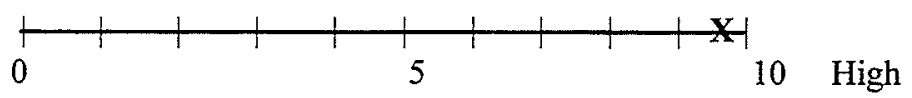

Current:

Low

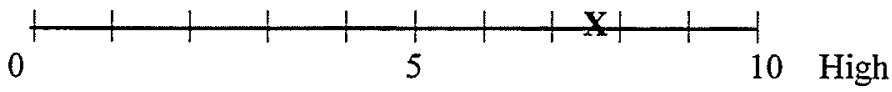

Figure 15. Final Questionnaire: Texas City Wye, Pilot 2 (Continued) 


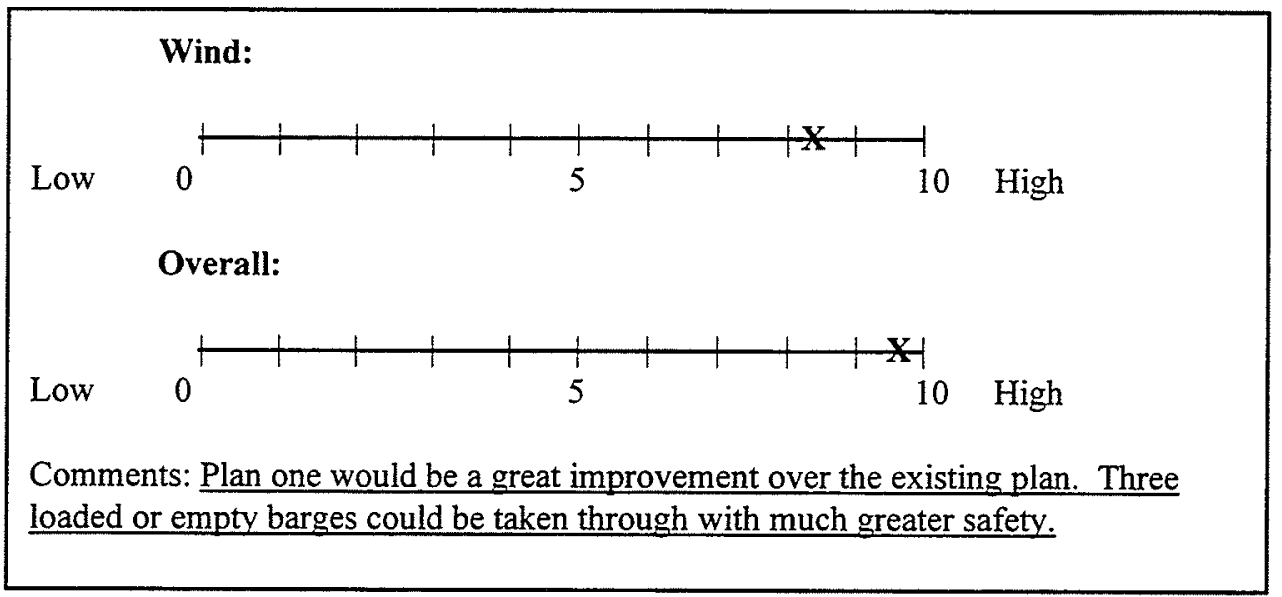

Figure 15. (Concluded)

\section{GALVESTON CAUSEWAY FINAL DEBRIEFING QUESTIONNAIRE}

Based on the week of simulation you have just completed, please put an $\mathrm{x}$ on the scale in answer to the question. Please use the comments section to explain your choices and be as specific as possible. Use the back of the form if necessary.

1. Comparing Plan 1 to the existing channel, rate the safety improvement for Plan

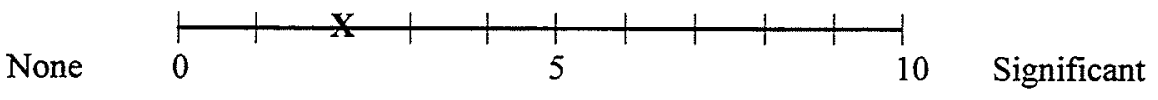

2. Comparing Plan 2 to the existing channel, rate the safety improvement for Plan 2.

None

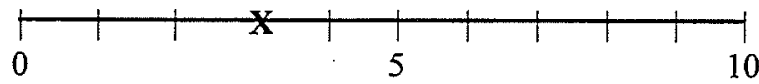

Significant

3. Rate the plan that you feel is the most safe choosing 0 as no difference:

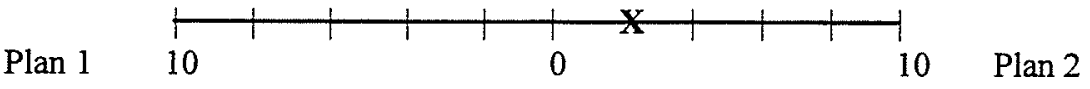

4. Rate the following simulator models/effects for realism:

Visuals:

Low

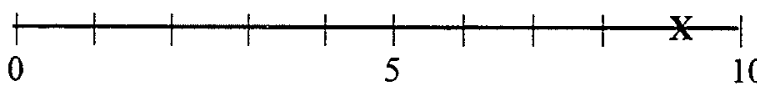

High

Figure 16. Final Questionnaire: Galveston Causeway, Pilot 3 (Continued) 


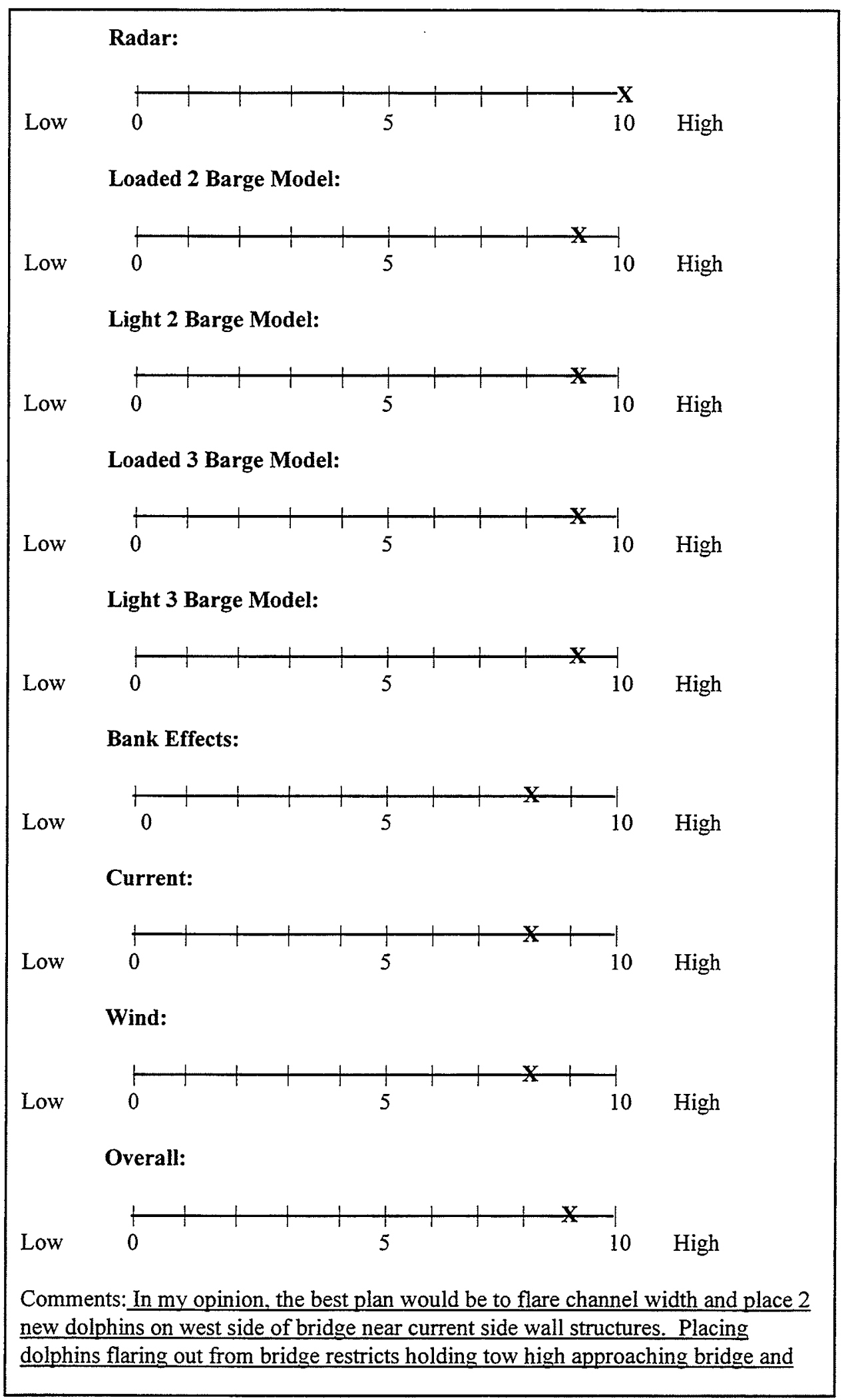

Figure 16. (Continued) 
increase the potential for damaging barges. I believe installing flared dolphins would create a barge mooring or staging area that would hamper movement through the area and cause increased congestion. By flaring the channel it would allow empty tows to approach the bridge at a greater angle allowing for better control and softer landing on dolphin prior to entering the walled structure. As I see it the best plan would be to flare channel and place landing dolphins with impact fendering to soften them and not install multiple dolphins extending out from the bridge.

Figure 16. (Concluded)

\section{TEXAS CITY WYE FINAL DEBRIEFING OUESTIONNAIRE}

1. Comparing Plan 1 to the existing channel, rate the safety improvement for Plan 1.

None

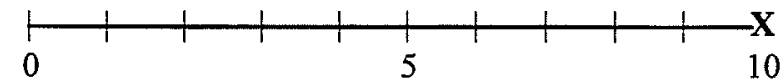

Significant

2. Rate the following simulator models/effects for realism:

Visuals:

Low

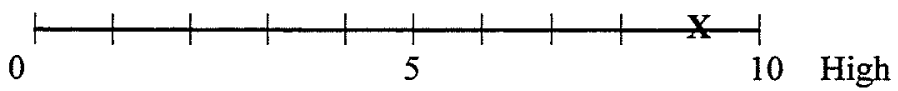

Radar:

Low

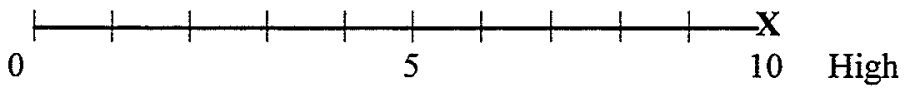

Loaded 2 Barge Model:

Low

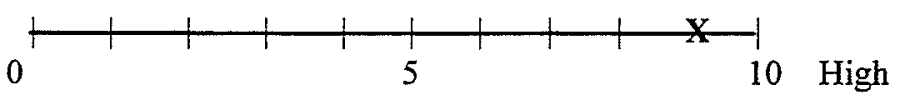

Light 2 Barge Model:

Low

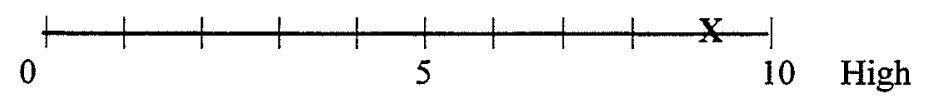

Loaded 3 Barge Model:

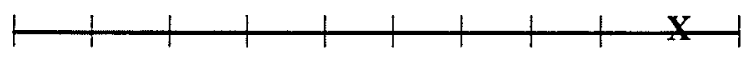
Low
0
5
10 High

Figure 17. Final Questionnaire: Texas City Wye, Pilot 3 (Continued) 


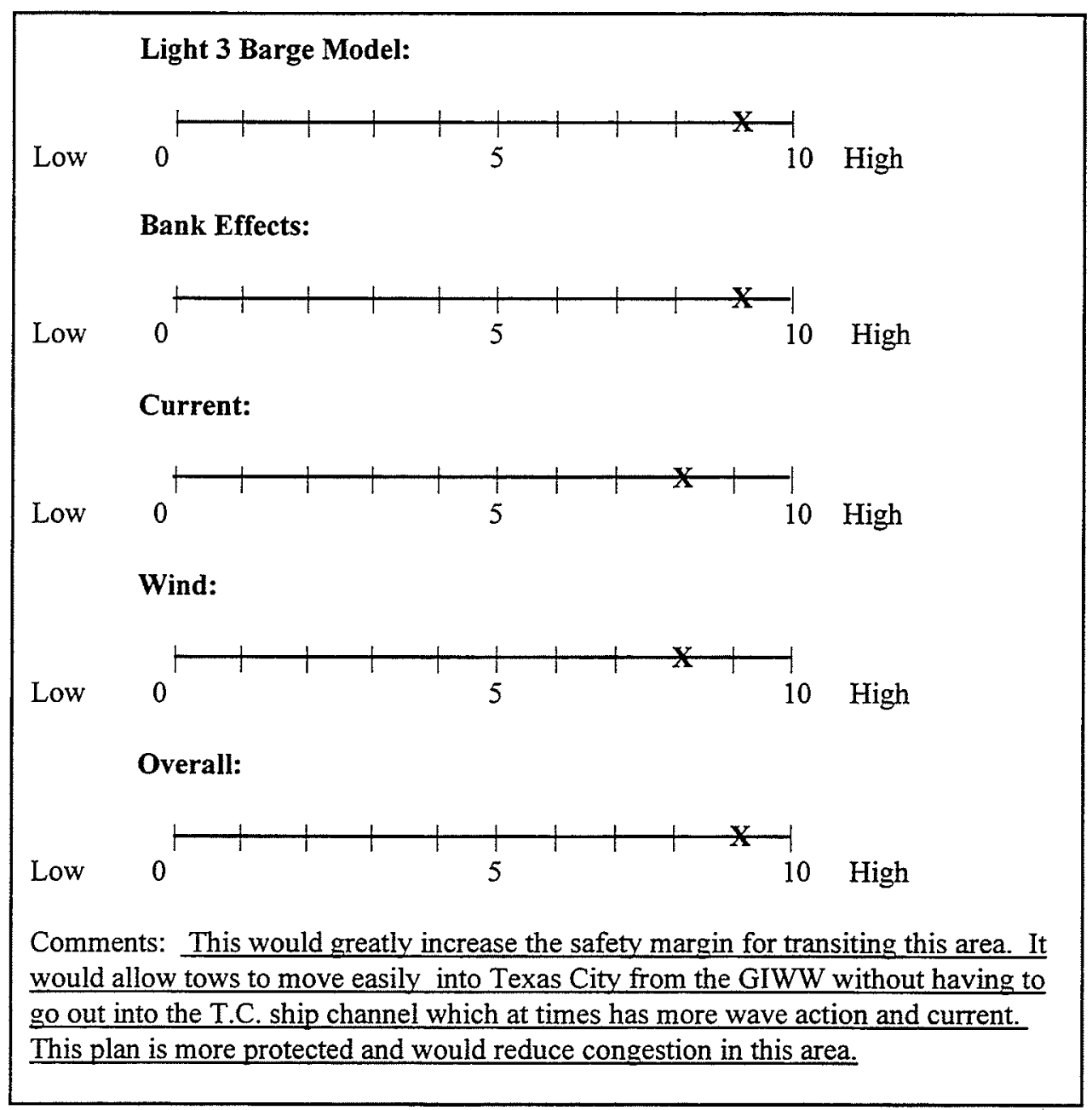

Figure 17.(Concluded)

\section{GALVESTON CAUSEWAY FINAL DEBRIEFING QUESTIONNAIRE}

Based on the week of simulation you have just completed, please put an $\mathrm{x}$ on the scale in answer to the question. Please use the comments section to explain your choices and be as specific as possible. Use the back of the form if necessary.

1. Comparing Plan 1 to the existing channel, rate the safety improvement for Plan

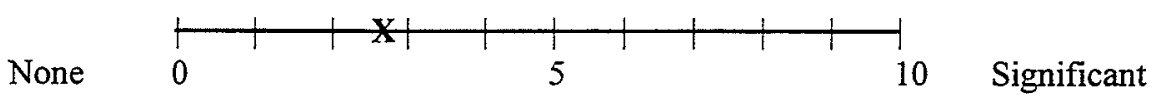

Figure 18. Final Questionnaire: Galveston Causeway, Pilot 5 (Continued) 
2. Comparing Plan 2 to the existing channel, rate the safety improvement for Plan 2.

None

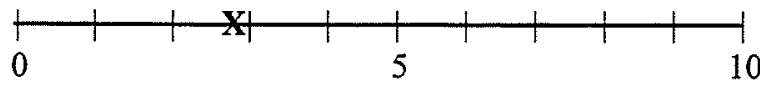

Significant

3. Rate the plan that you feel is the most safe choosing 0 as no difference:

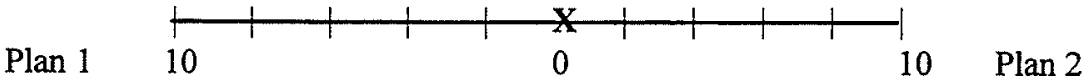

4. Rate the following simulator models/effects for realism:

Visuals:

Low

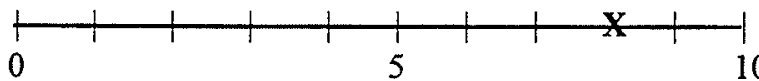

High

Radar:

Low

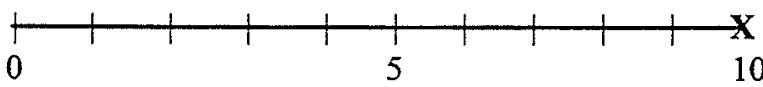

High

Loaded 2 Barge Model:

Low

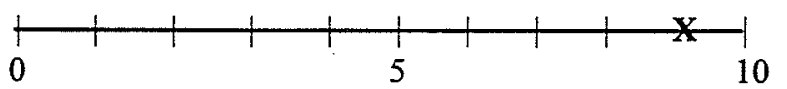

High

Light 2 Barge Model:

Low

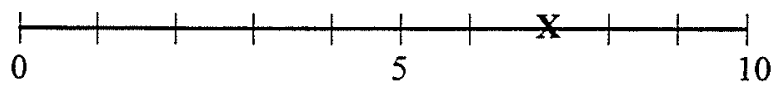

High

Loaded 3 Barge Model:

Low

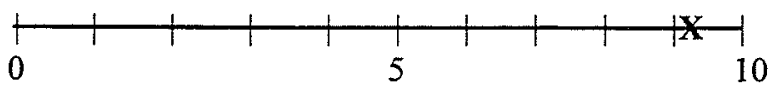

High

Light 3 Barge Model:

Low

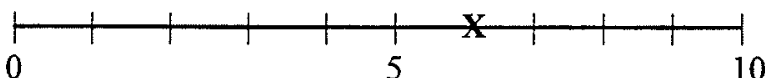

High

Bank Effects:

Low

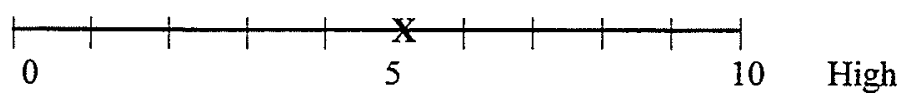

Figure 18. (Continued) 


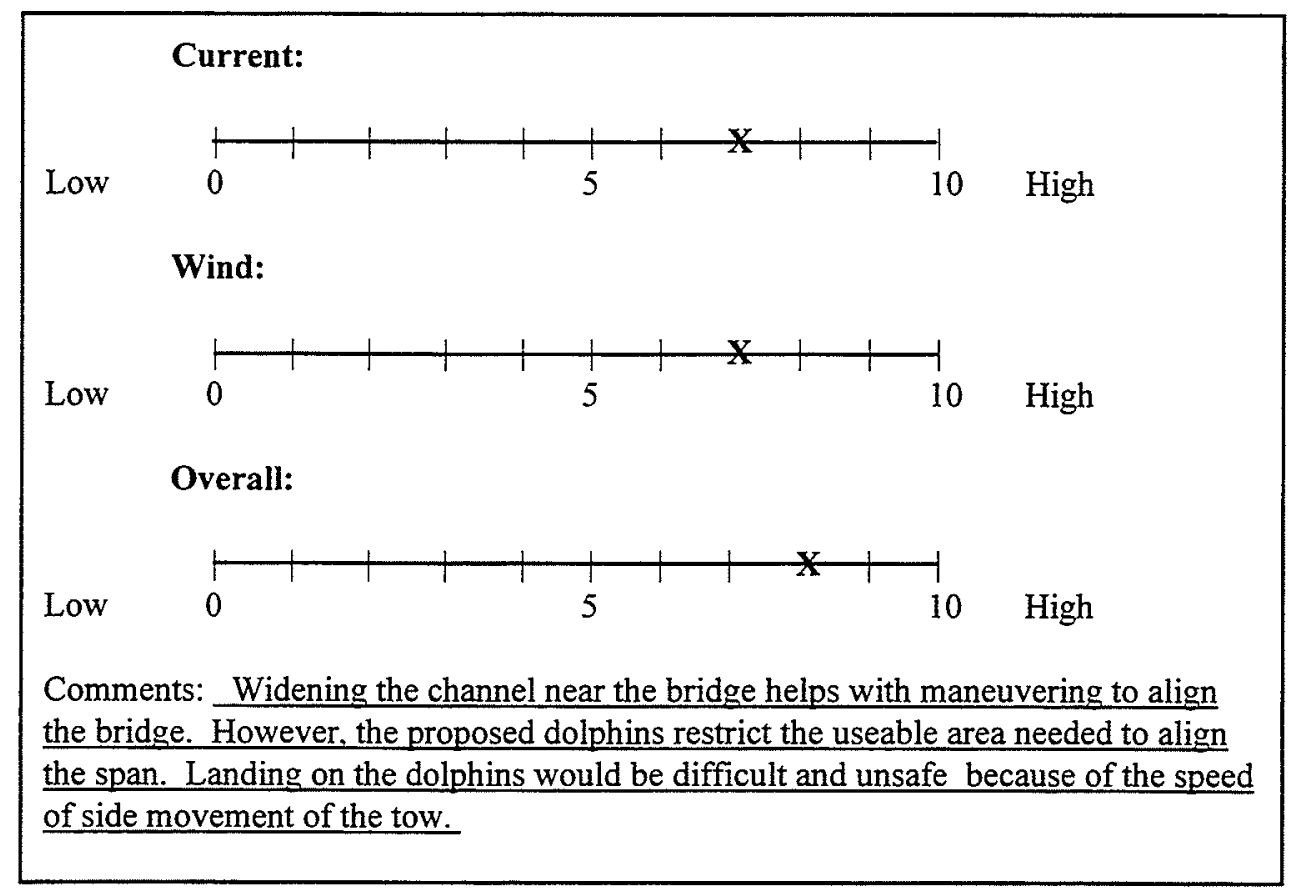

Figure 18. (Concluded)

\section{CHOCOLATE BAYOU FINAL DEBRIEFING QUESTIONNAIRE}

1. Comparing Plan 1 to the existing channel, rate the safety improvement for Plan 1.

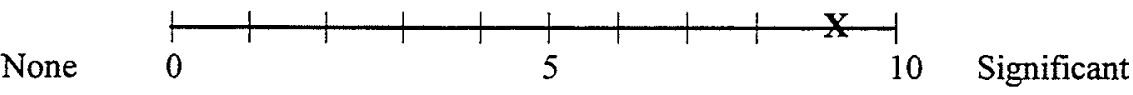

2. Rate the following simulator models/effects for realism:

Visuals:

Low

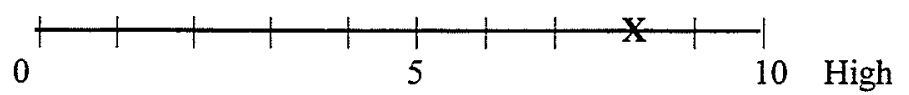

Radar:

Low

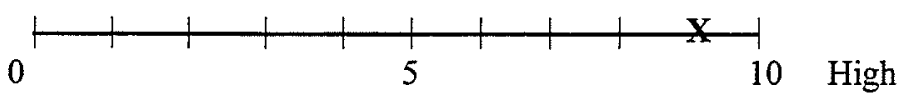

Loaded 2 Barge Model:

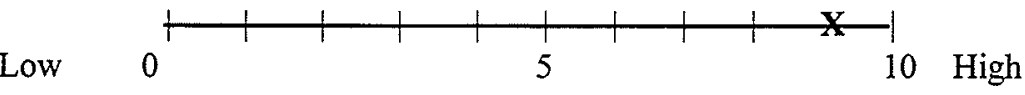

Figure 19. Final Questionnaire: Chocolate Bayou, Pilot 5 (Continued) 


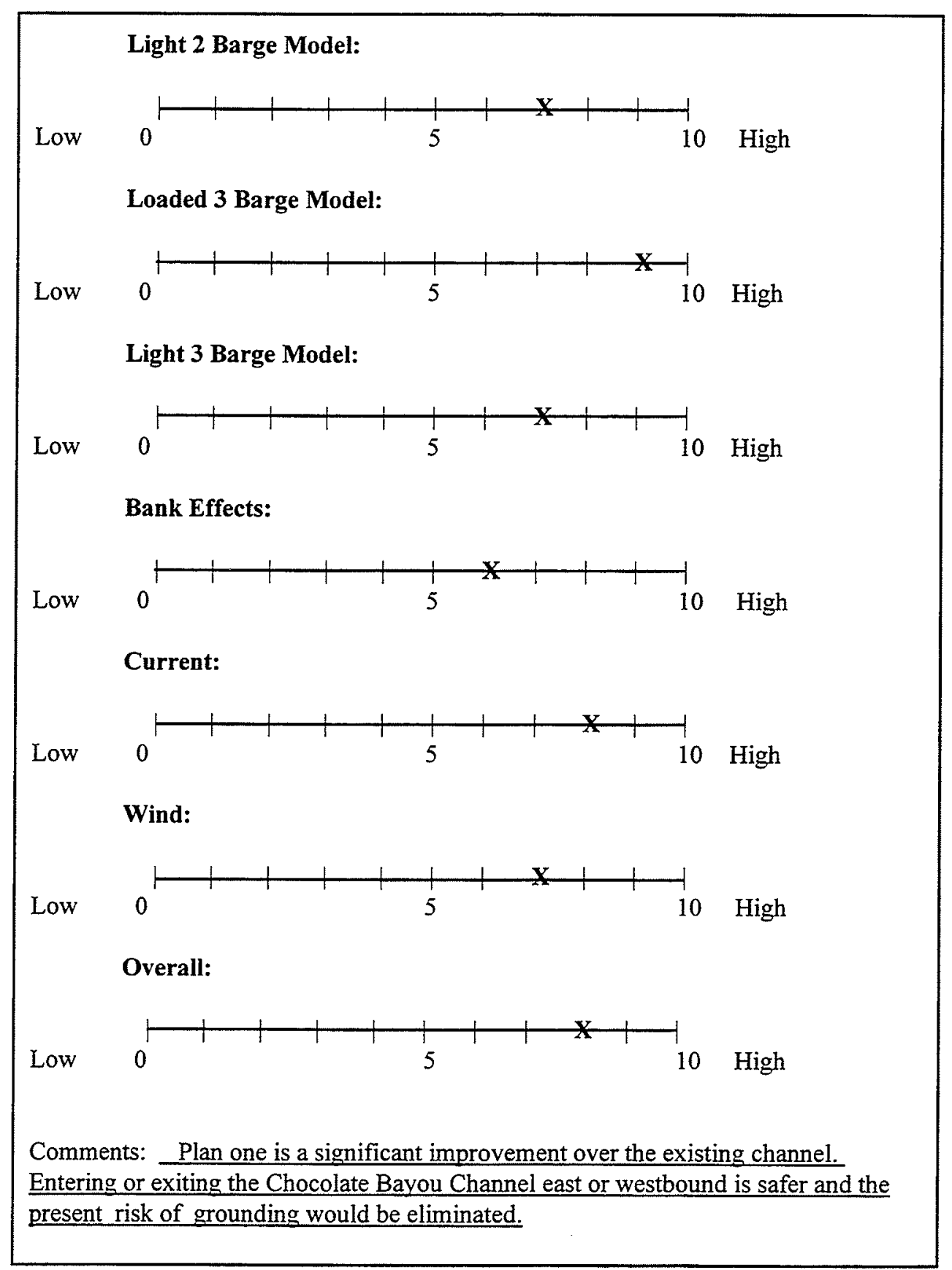

Figure 19. (Concluded) 


\section{TEXAS CITY WYE \\ FINAL DEBRIEFING QUESTIONNAIRE}

1. Comparing Plan 1 to the existing channel, rate the safety improvement for Plan 1.

None

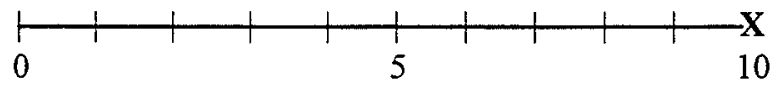

Significant

2. Rate the following simulator models/effects for realism:

Visuals:

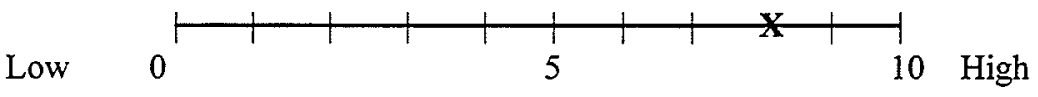

Radar:

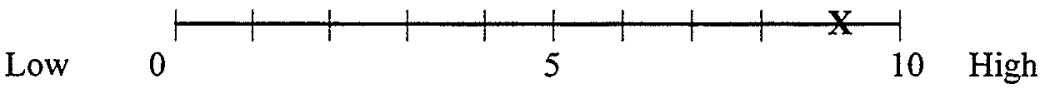

Loaded 2 Barge Model:

Low

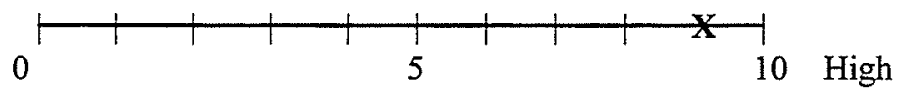

Light 2 Barge Model:

Low

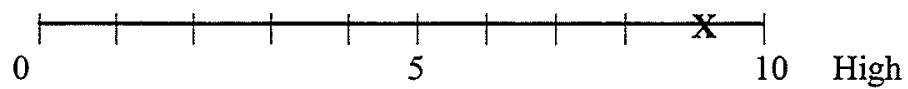

Loaded 3 Barge Model:

Low

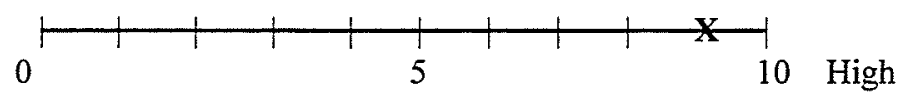

Light 3 Barge Model:

Low

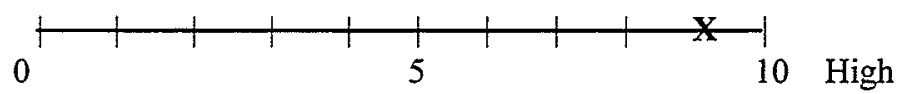

Bank Effects:

Low

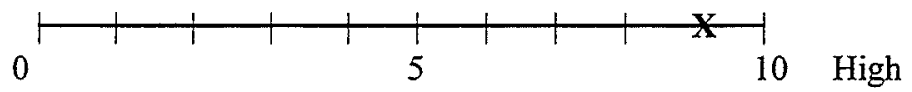

Figure 20. Final Questionnaire: Texas City Wye, Pilot 5 (Continued) 


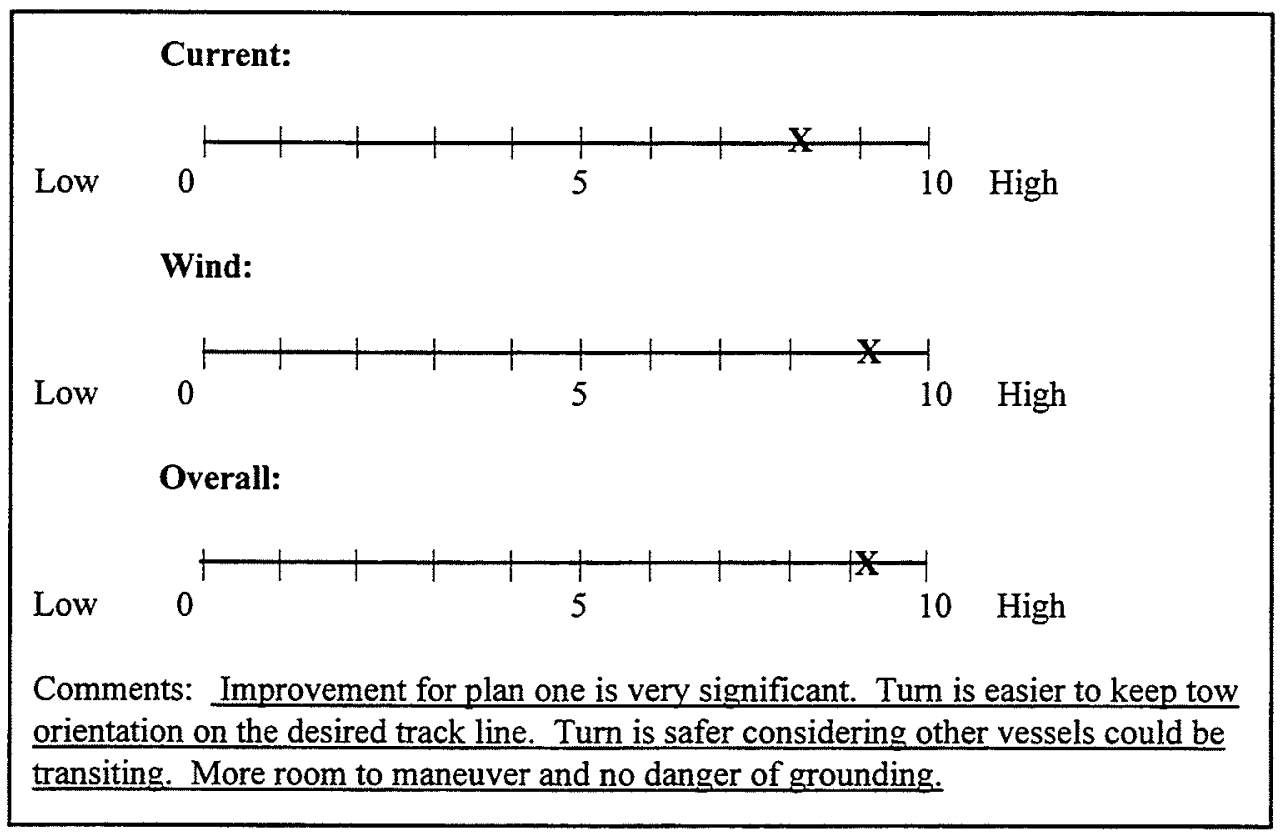

Figure 20. (Concluded)

\section{GALVESTON CAUSEWAY FINAL DEBRIEFING QUESTIONNAIRE}

Based on the week of simulation you have just completed, please put an $\mathrm{x}$ on the scale in answer to the question. Please use the comments section to explain your choices and be as specific as possible. Use the back of the form if necessary.

1. Comparing Plan 1 to the existing channel, rate the safety improvement for Plan

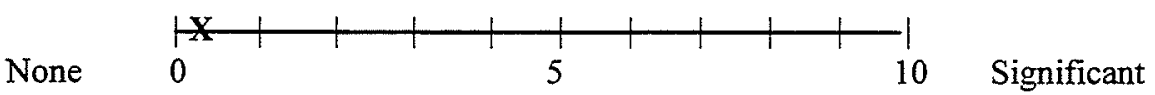

2. Comparing Plan 2 to the existing channel, rate the safety improvement for Plan 2.

None

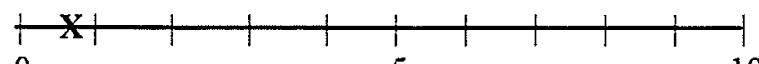

Significant

3. Rate the plan that you feel is the most safe choosing 0 as no difference:

Plan 1

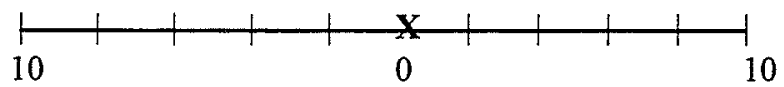

Plan 2

Figure 21. Final Questionnaire: Galveston Causeway, Pilot 6 (Continued) 
4. Rate the following simulator models/effects for realism:

Visuals:

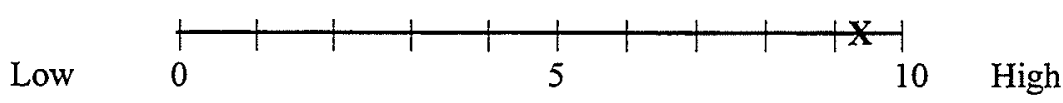

Radar:

Low

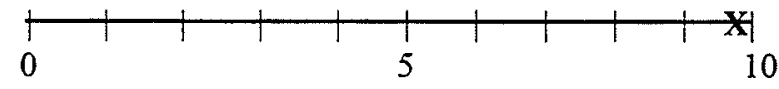

High

Loaded 2 Barge Model:

Low

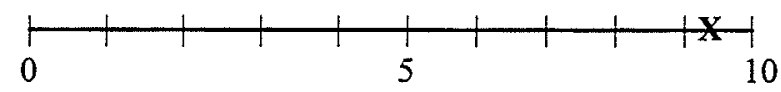

High

Light 2 Barge Model:

Low

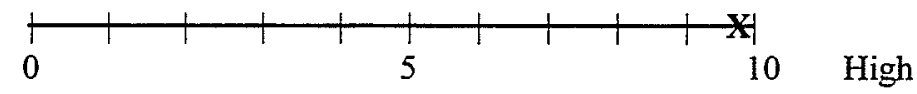

Loaded 3 Barge Model:

Low

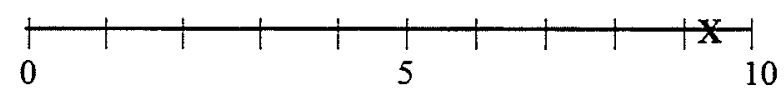

High

Light 3 Barge Model:

Low

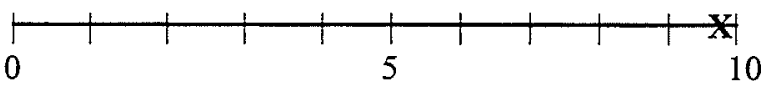

High

Bank Effects:

Low

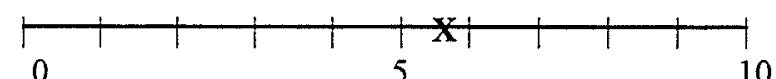

High

\section{Current:}

Low

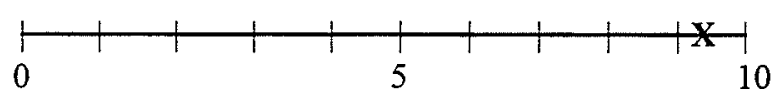

High

Wind:

Low

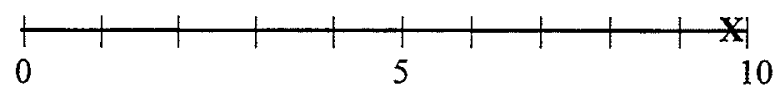

High

Figure 21. (Continued) 


\section{Overall:}

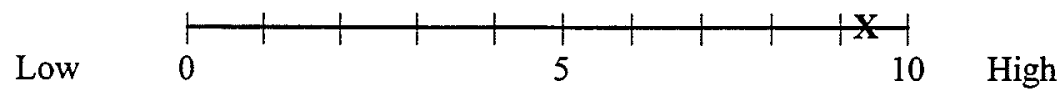

Comments: Plan three which is not on this questionnaire, would make the best improvement. It would keep you from having to make a bend and then having to line up on the causeway. Also it would help reduce groundings in this area by $50 \%$.

Figure 21. (Concluded)

\section{CHOCOLATE BAYOU FINAL DEBRIEFING QUESTIONNAIRE}

1. Comparing Plan 1 to the existing channel, rate the safety improvement for Plan 1 .

None

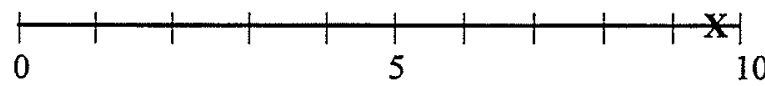

Significant

2. Rate the following simulator models/effects for realism:

Visuals:

Low

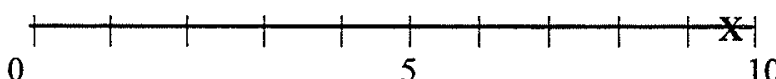

High

Radar:

Low

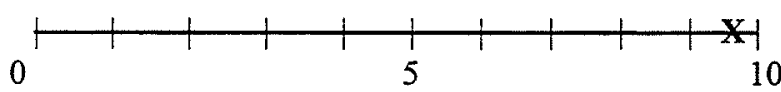

High

Loaded 2 Barge Model:

Low

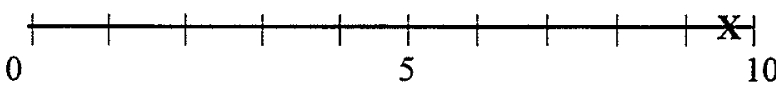

High

Light 2 Barge Model:

Low

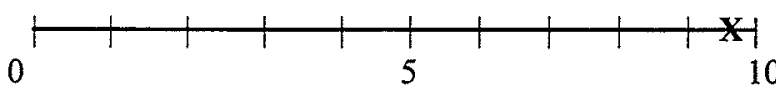

High

Loaded 3 Barge Model:

Low

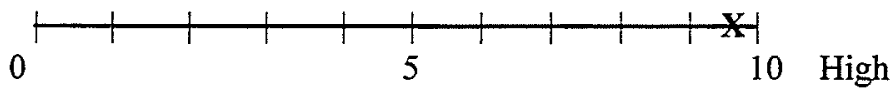

Figure 22. Final Questionnaire: Chocolate Bayou, Pilot 6 (Continued) 


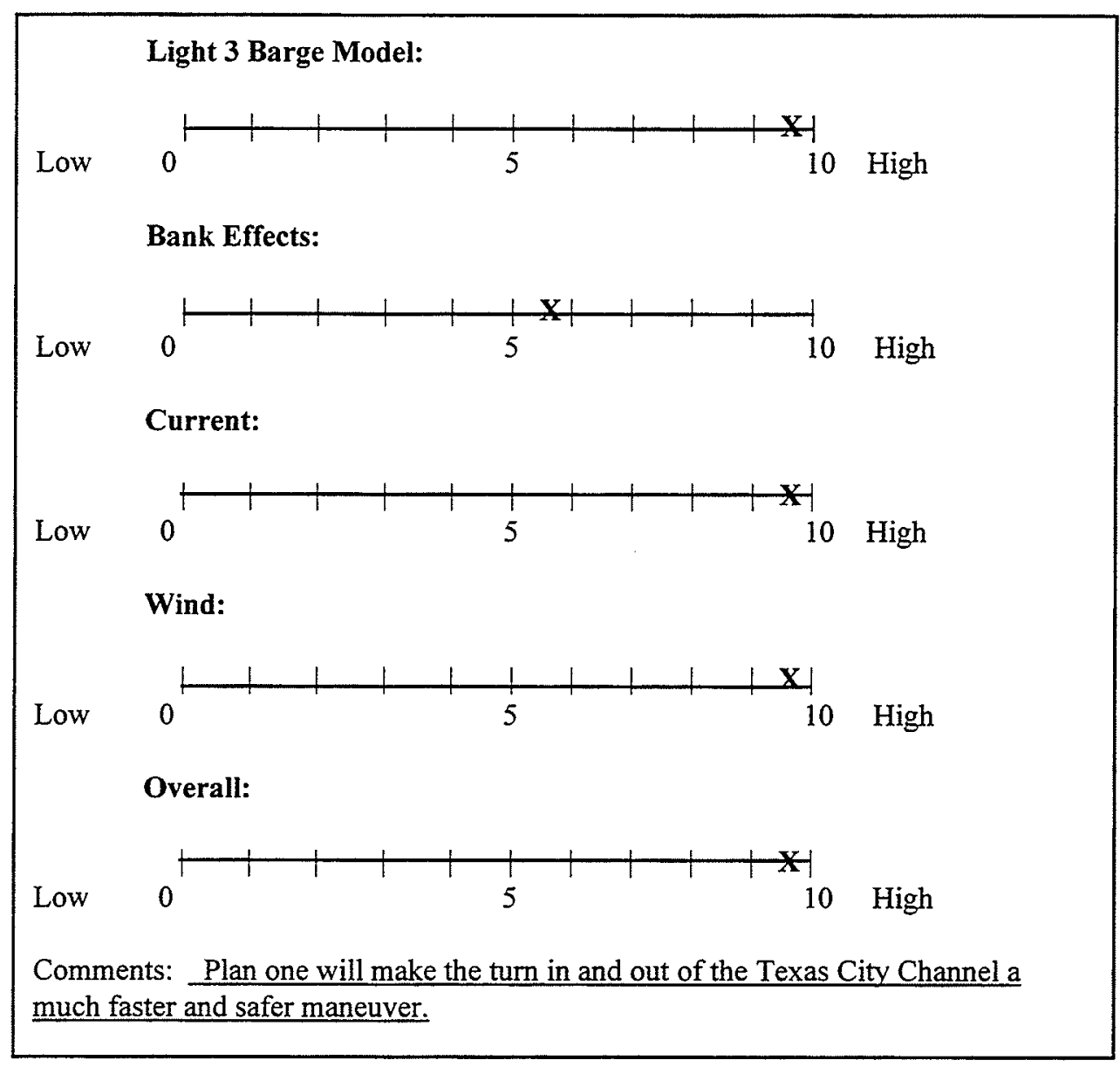

Figure 22. (Concluded)

\section{TEXAS CITY WYE FINAL DEBRIEFING QUESTIONNAIRE}

1. Comparing Plan 1 to the existing channel, rate the safety improvement for Plan 1.

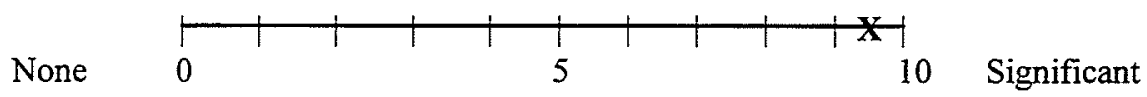

2. Rate the following simulator models/effects for realism:

Visuals:

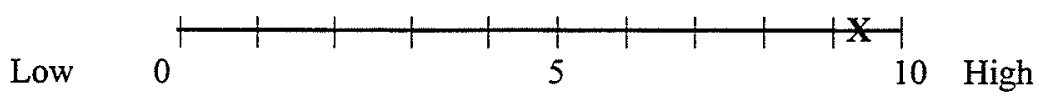

Figure 23. Final Questionnaire: Texas City Wye, Pilot 6 (Continued) 


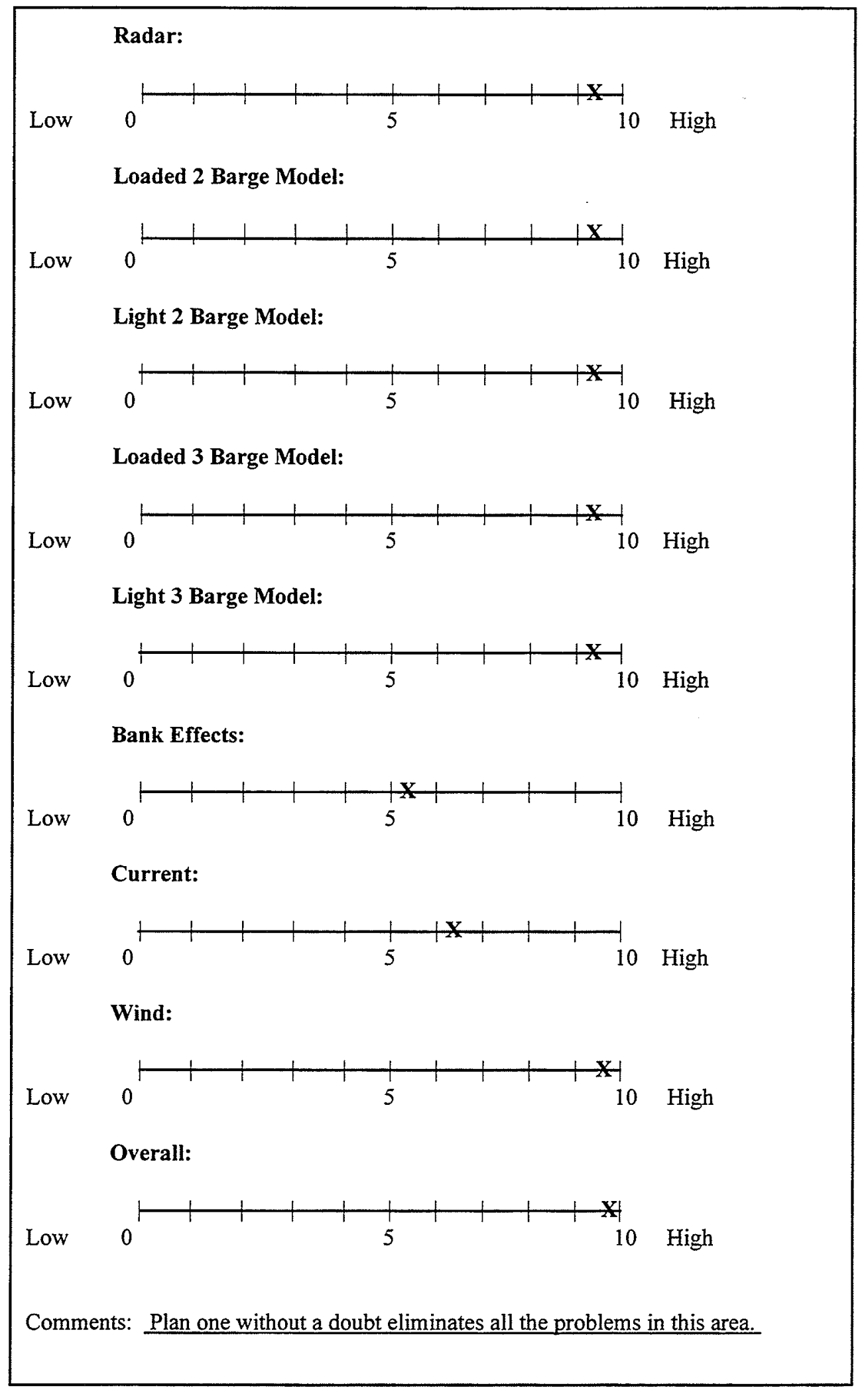

Figure 23. (Concluded) 


\section{Conclusions and Recommendations}

\section{Galveston Causeway}

The success rate of tows pushing loaded barges through the fender system was significantly higher than that of tows pushing empty barges. This is true for the existing and proposed conditions. The pilots experienced many problems lining up the empty barges prior to entering the fender system. These problems were caused by wind and are similar to problems encountered in real life. This is verified by the pilots' final questionnaire in which they rated the simulation of the barges and wind as highly realistic.

Analysis of the simulation results reveals that there are no "easy" solutions to navigation problems at the Galveston Causeway. The width between the fenders is $110 \mathrm{ft}$, approximately $20 \mathrm{ft}$ narrower than most of the GIWW. Empty barges draft about $3 \mathrm{ft}$ and often leave the authorized channel by extending over the side slopes. However, the pilots cannot use the channel side slopes while passing through the Galveston Causeway because the bridge fenders extend above the water line. Assuming a 1:3 channel side slope, using the channel side slopes for empty barges increases the channel width by approximately 60 percent. Unfortunately, replacement of the existing bridge spans is not presently an option. When the spans are rebuilt, a suitable fender width should be developed prior to any structural modifications. The existing simulator model can be modified to simulate multiple fender widths.

Based on the results of the simulation and the pilots who responded to the questionnaire, widening the approach channels to the causeway would help somewhat, but the proposed cells would be a hazard. An additional proposed channel re-alignment, Plan 3, was developed during the last week of testing. This plan consisted of a major realignment of the navigation channel in the vicinity of the Galveston Causeway and resulted in a much longer straight approach. There was not sufficient time to investigate this plan, but the two pilots, SWG personnel and WES personnel present felt that this plan showed more potential than the other two plans. In theory, the lengthening of the straight section approaching the bridge would allow the pilots to finish negotiating the bend and then have sufficient time to orient the tow with respect to the wind and/or current before maneuvering through the causeway span. It is recommended that this plan be considered further and if deemed feasible, further experiments should be conducted to determine if navigation conditions would be significantly improved by this modification. 


\section{Chocolate Bayou}

The proposed turn, which opens the entire area at the intersection, showed significant improvement over the existing, separate east / west lanes. However, the sterns of many inbound tows crossed the southern edge of the channel while turning north into Chocolate Bayou. In addition, many of the outbound runs were unable to complete the turn into the $125 \mathrm{ft}$ wide GIWW without running aground. Therefore, widening the southern side of the channel by $100 \mathrm{ft}$ is recommended. This widening, shown in Figure 24, allows the stern of inbound tows to swing wide and provides additional transition room for outbound tows.

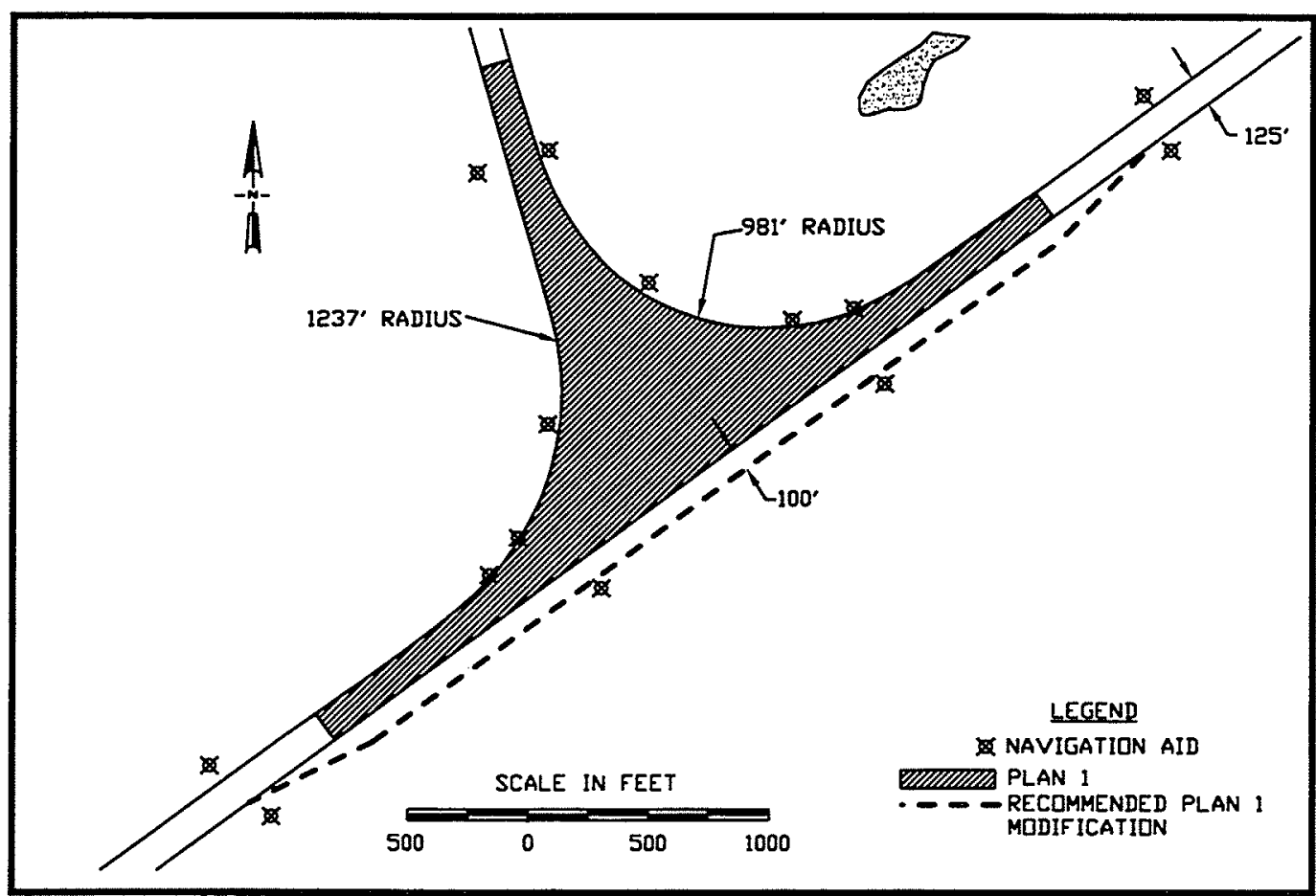

Figure 24. Chocolate Bayou, Recommended Plan 1

\section{Texas City Wye}

Based upon the results of the simulation program the following conclusions can be made:

1. The proposed widening improved navigation for tows turning between the GIWW and the Texas City Channel.

2. A significant number of both two- and three-barge inbound tows began their turn early and left the authorized limits of the GIWW on the north-west side just prior to entering the widener. 
3. A number of tows, both inbound and outbound, left the authorized limits of the Texas City Channel near the end of the Texas City Dike. The Texas City Channel is $40 \mathrm{ft}$ deep and the tows draft $9 \mathrm{ft}$. Therefore, the majority of these runs remained in water of navigable depth.

4. Nearly all of the runs in the proposed widener maintained a significant clearance from the western edge of the widener.

The following recommendations are made:

1. The bend on the west side of the Texas City should be widened. The plan tested at WES can be improved as shown in Figure 25. This will reduce the dredged area by nearly 30 percent and allow the pilots to begin their inbound turn early. It will also give outbound tows a wider "target" after completing the turn.

2. An ATON marking the $12 \mathrm{ft}$ contour on the east side of the Texas City Channel should be considered. This is the area where a number of tows left the $40 \mathrm{ft}$ deep ship channel. The Galveston/Texas City Pilots should be consulted before requesting that the U.S. Coast Guard install a channel marker in this area. An estimated position for the marker is shown in Figure 25.

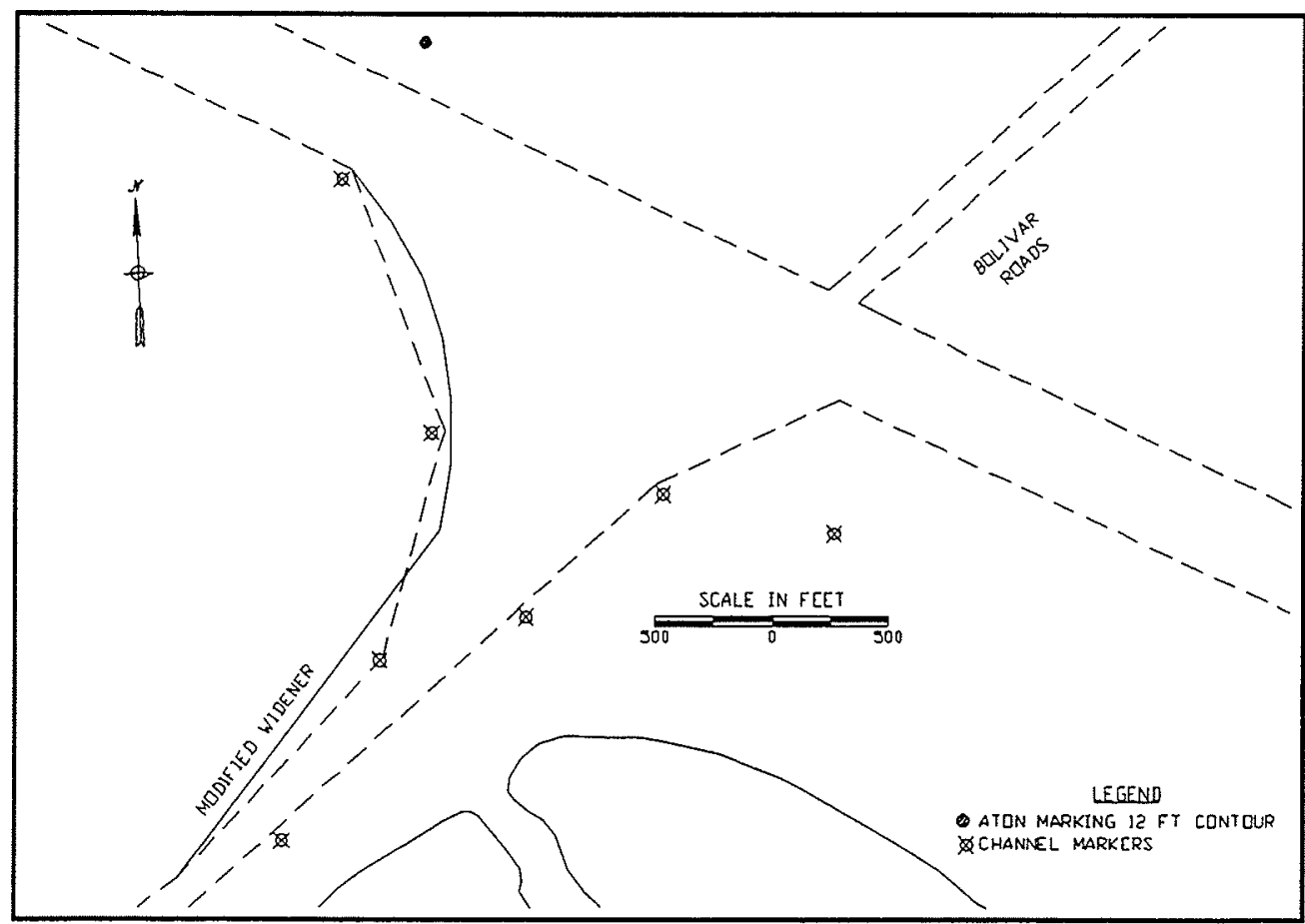

Figure 25. Texas city Wye, Recommended Modification to Proposed Plan 
Figure 26 shows all proposed condition runs overlaid on the modified widener. Obviously, this widener accommodates nearly all transits simulated.

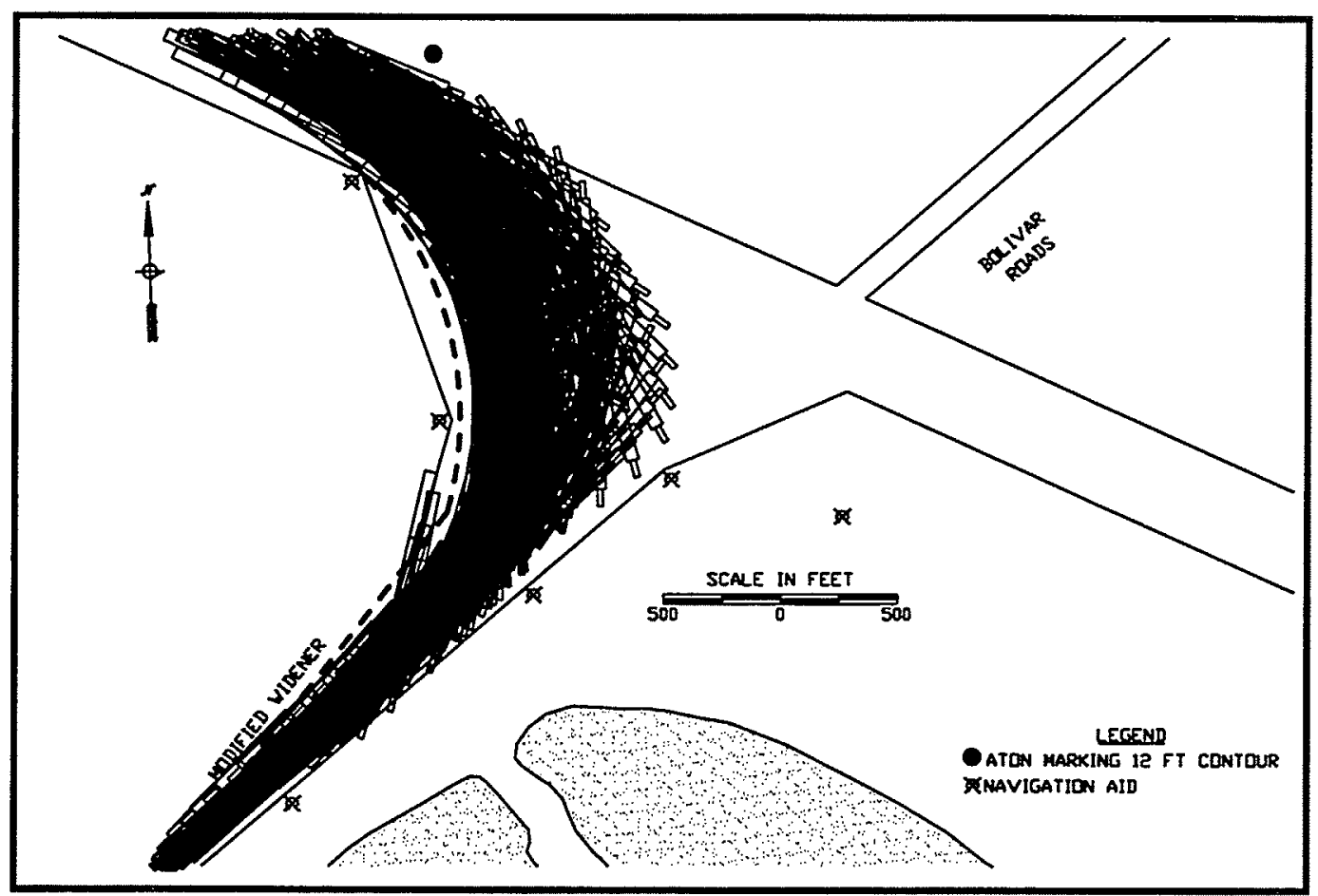

Figure 26. Composite Track, All Proposed Plan Runs 


\section{Appendix A Flow Modeling}

\section{Numerical Model}

The WES numerical modeling system, "Open-Channel Flow and Sedimentation, TABS-2", ${ }^{1}$ was used in the evaluation of the impact of channel deepening and modification at Galveston Causeway, Texas City Wye, and Chocolate Bayou. The hydrodynamic predictions were used in the ship simulator evaluation of the proposed channel improvements. The numerical model used was "A Two-Dimensional Model for Free Surface Flows (RMA2V)." The code employs the finite element method to solve the depth-integrated governing equations.

\section{Computational Mesh}

The navigation channels are located in south eastern Texas along the Gulf of Mexico. Th capture all the necessary flows the computational mesh covered an area north from the mouth of the Trinity River to the southern portion of chocolate bayou. Depths were taken from National Oceanic and Atmospheric Administration charts except in the channel at Texas City, Galveston Causeway and Chocolate Bayou. Current survey charts were provided for these areas.

A numerical mesh was designed to represent the study area consisting of 14,167 nodes and 5,311 elements. Two-dimensional elements (quadrilateral and triangular) represented all the study area. The mesh was generated with high resolution in the navigation channels to represent the flow patterns in sufficient details to allow accurate representation of currents for the ship simulator.

A total of four meshes were developed. The initial mesh represented existing conditions in the study area. The remaining meshes described plan conditions within the channel at Texas City, Galveston Causeway, and Chocolate Bayou. Results generated by the hydrodynamic model for each condition were later used in the ship simulator.

\footnotetext{
1 William A. Thomas and William H. McAnnally, Jr. (1985). "User's Manual for the Generalized Computer Program System: Open-Channel Flow and Sedimentation, TABS-2; Main Text and Appendices A Through O," Instruction Report HL-85-1, U.S. Army Engineer Waterways Experiment Station, Vicksburg, MS.
} 



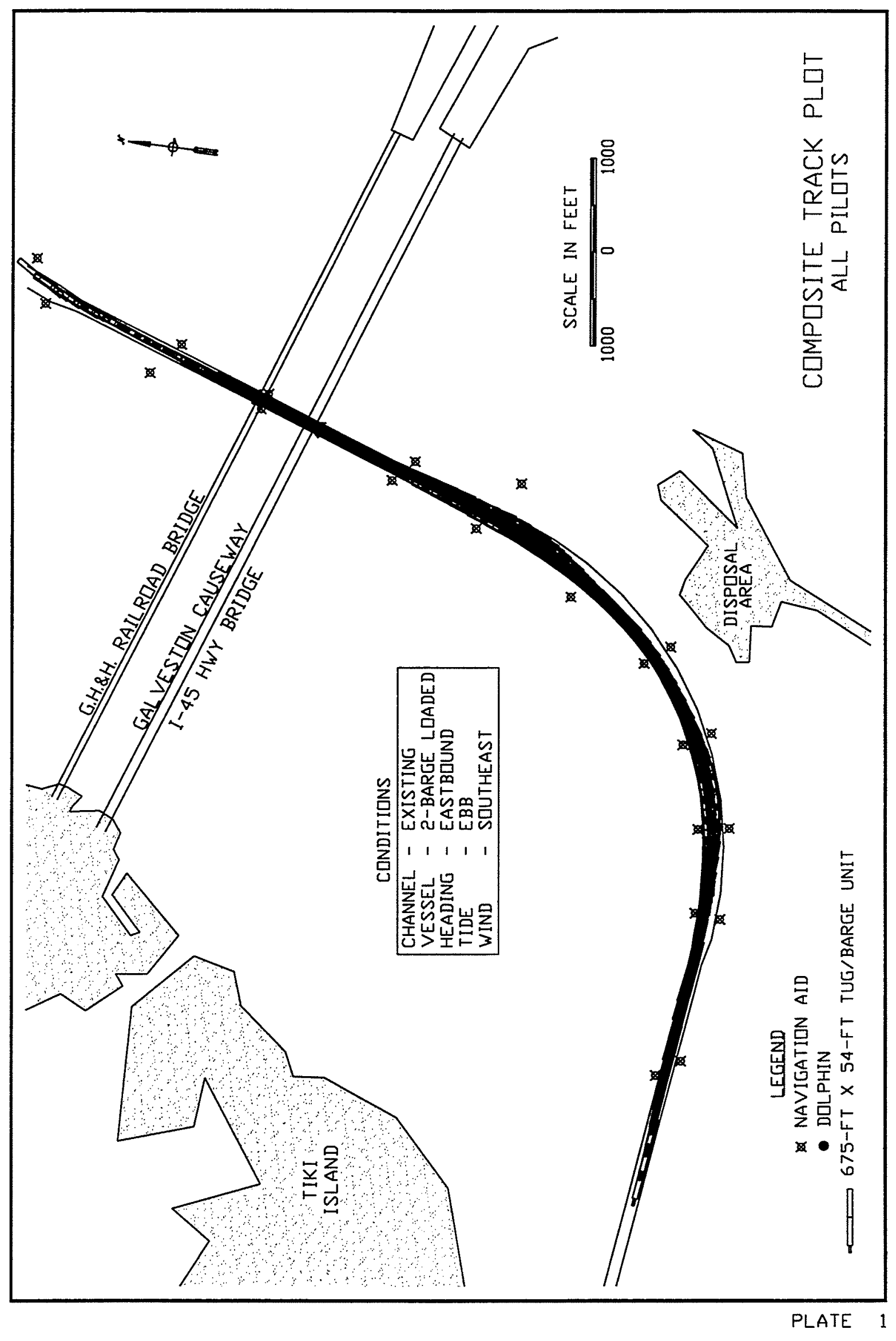




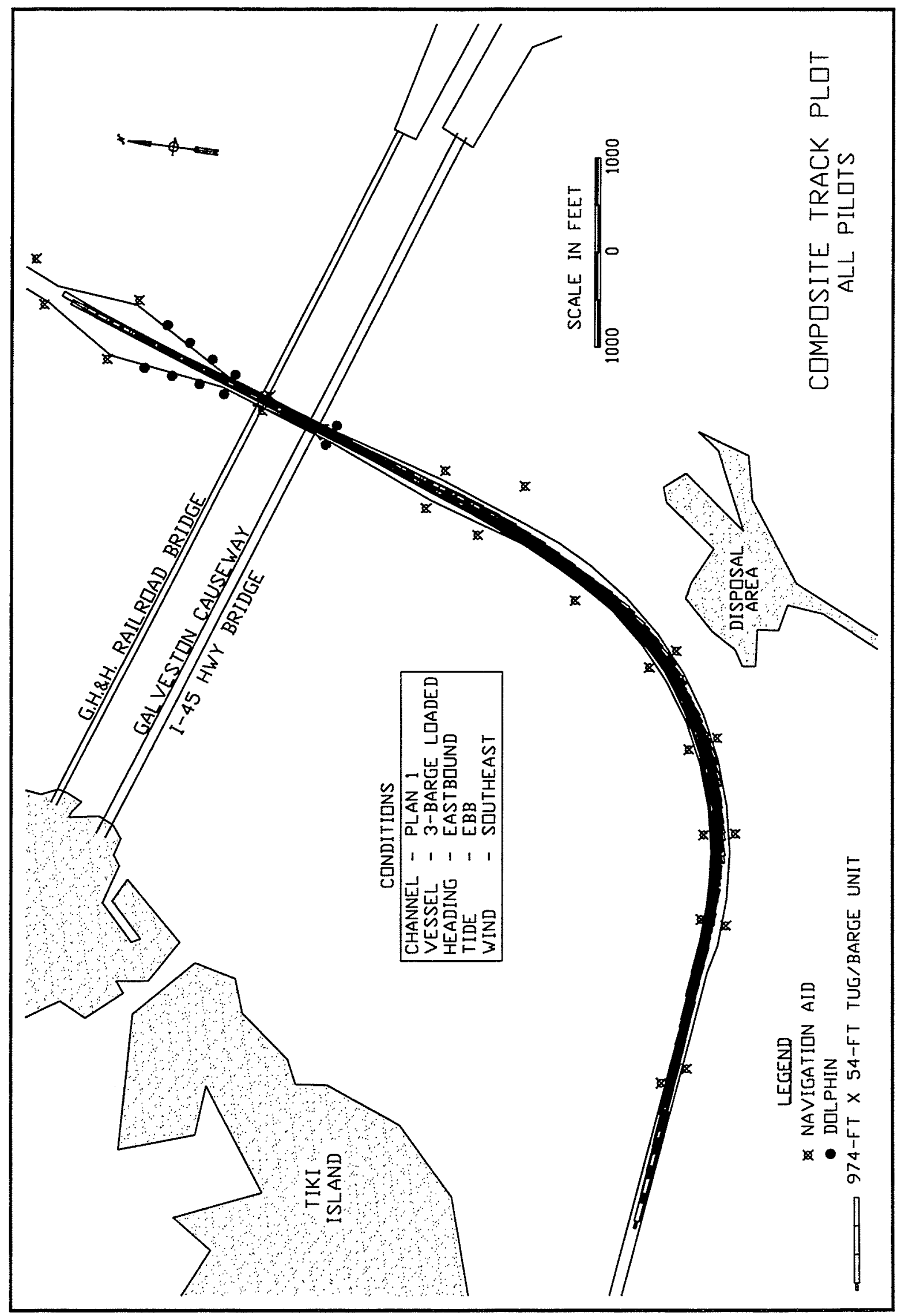

PLATE 2 


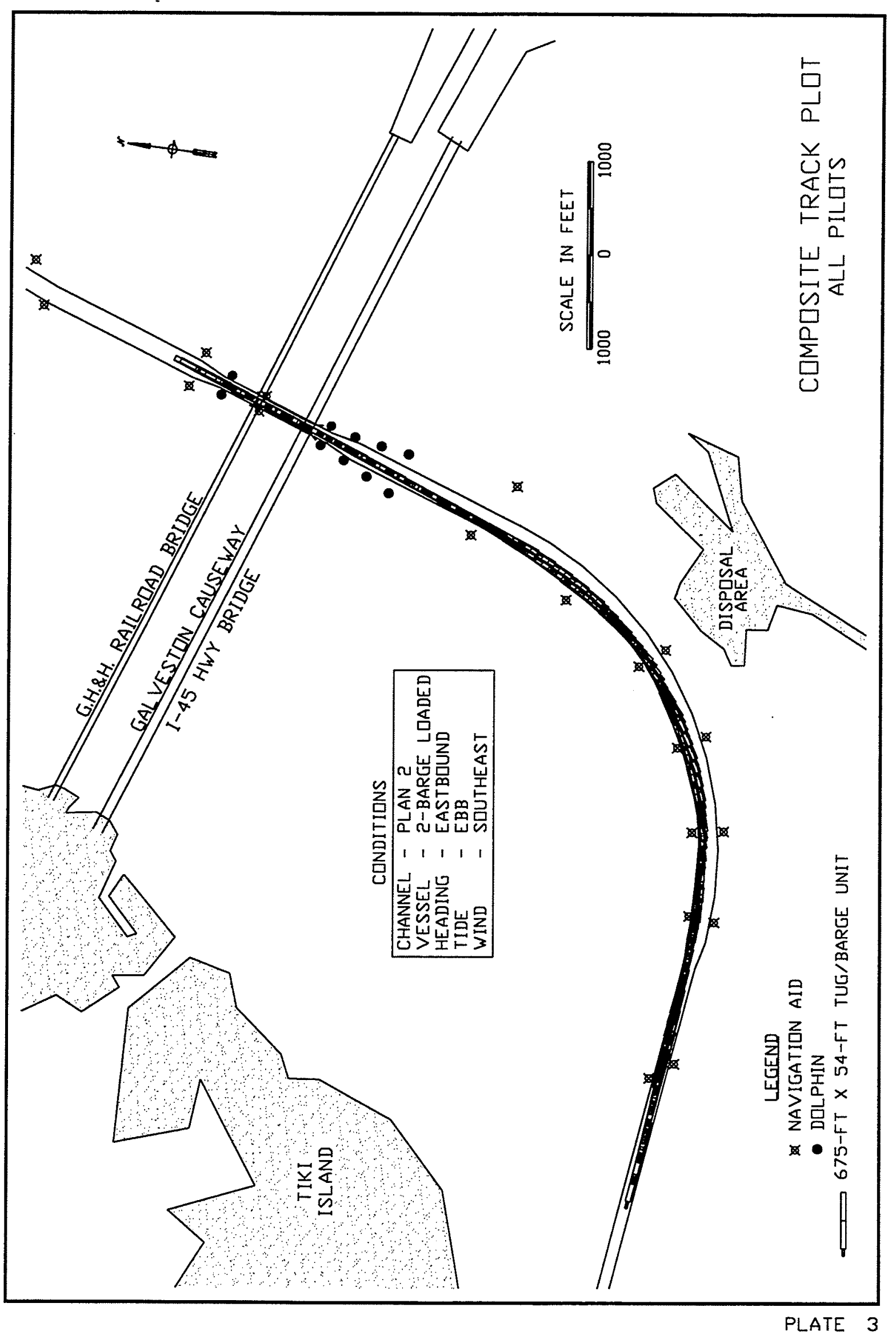




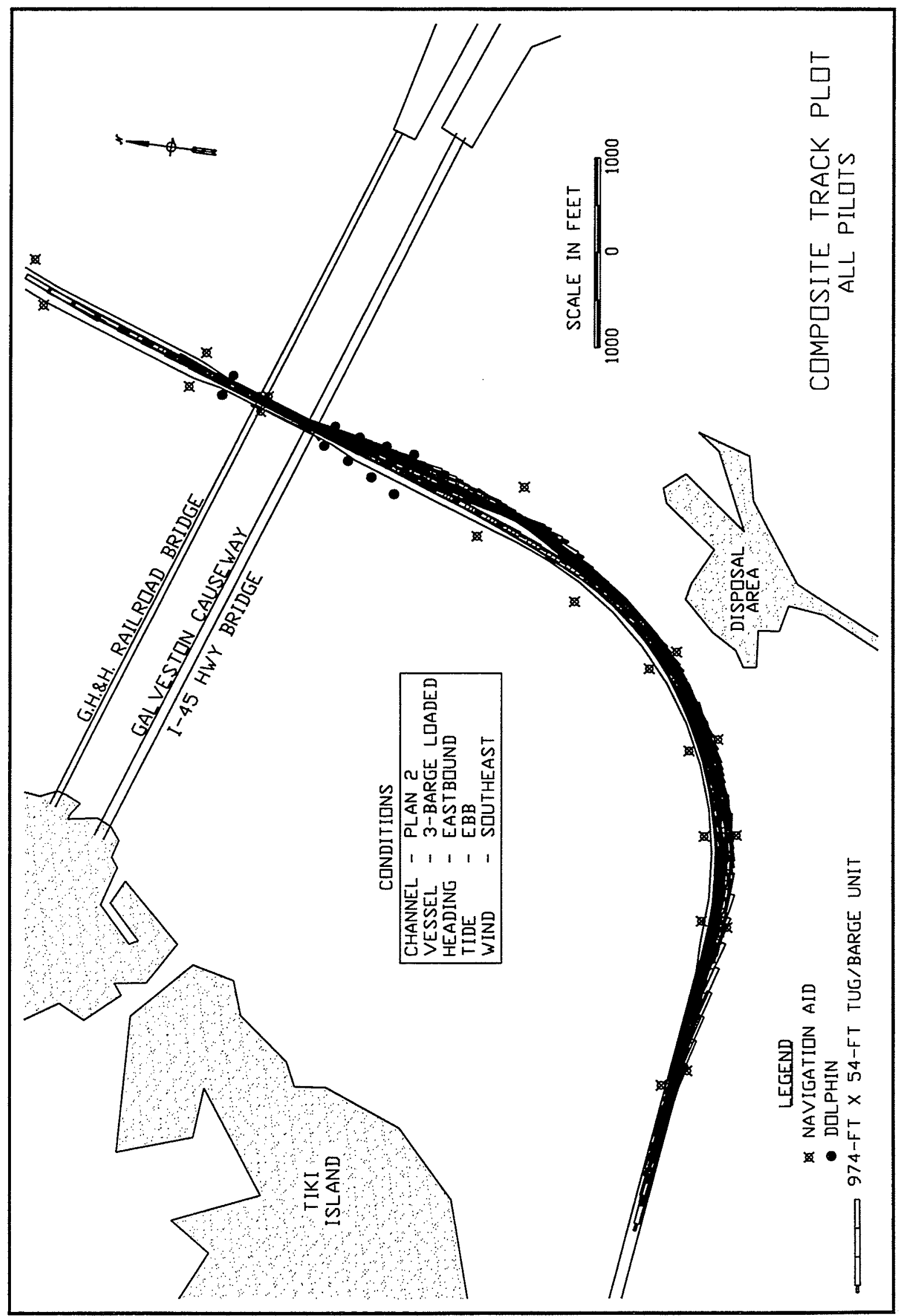

PLATE 4 


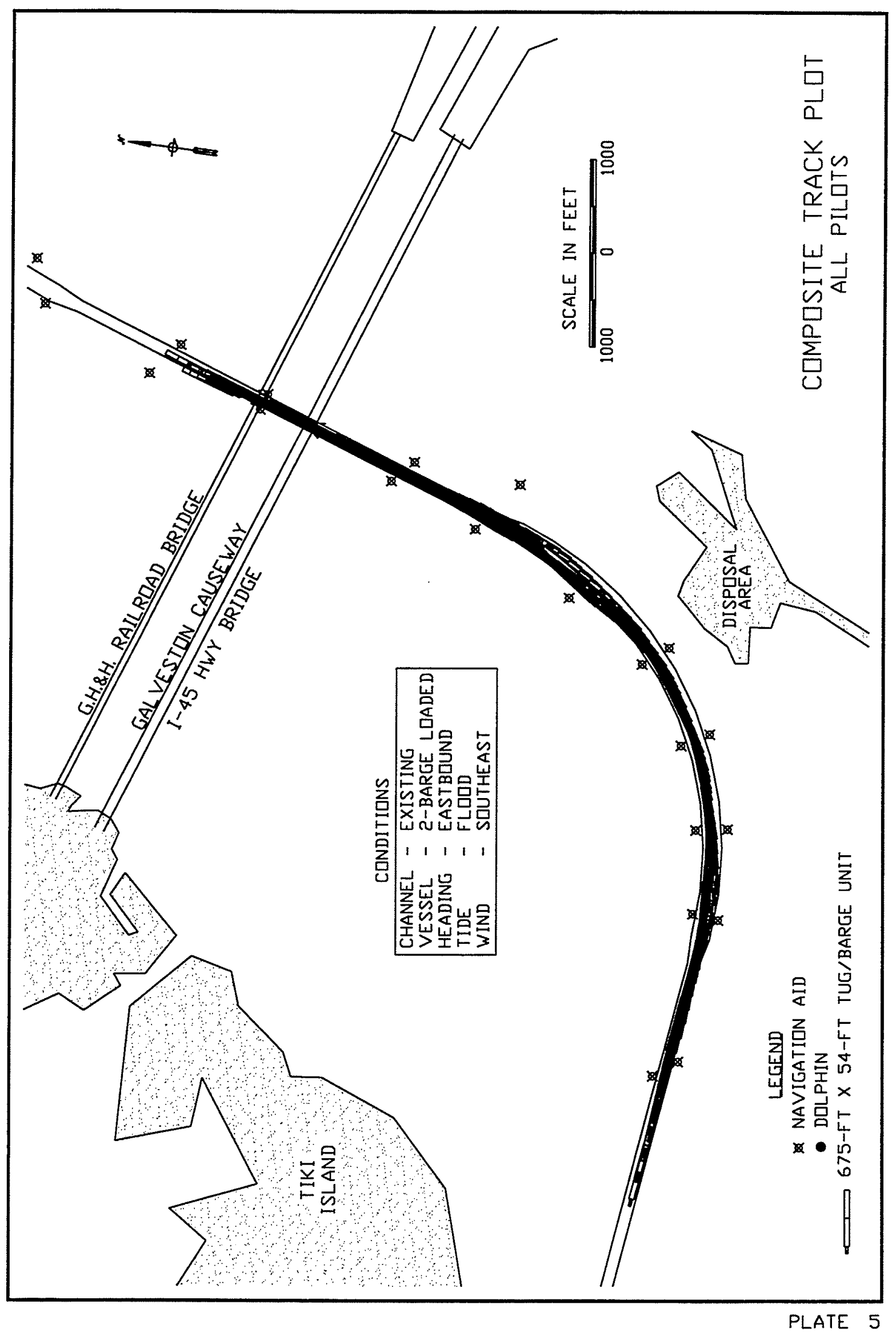




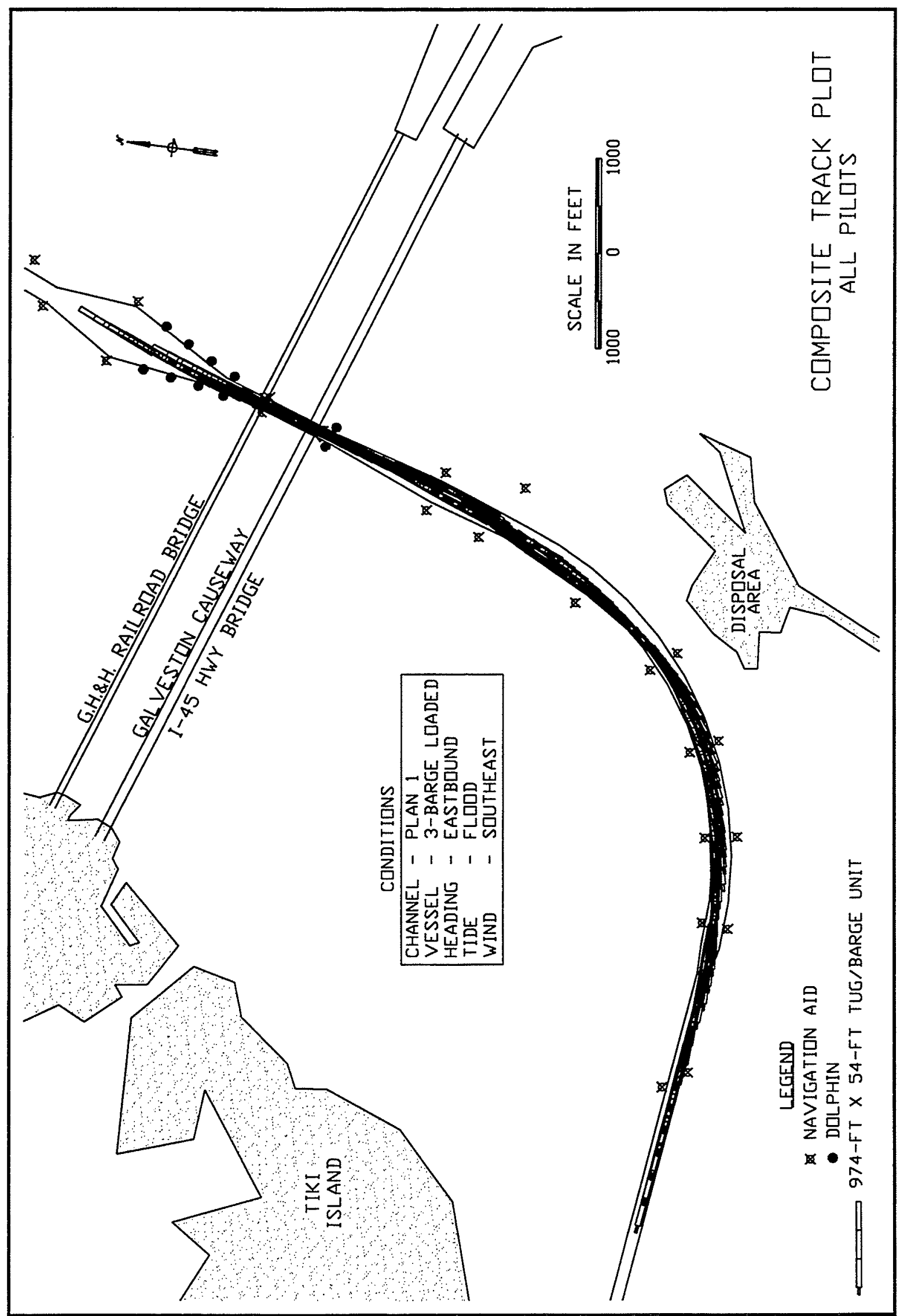

PLATE 6 


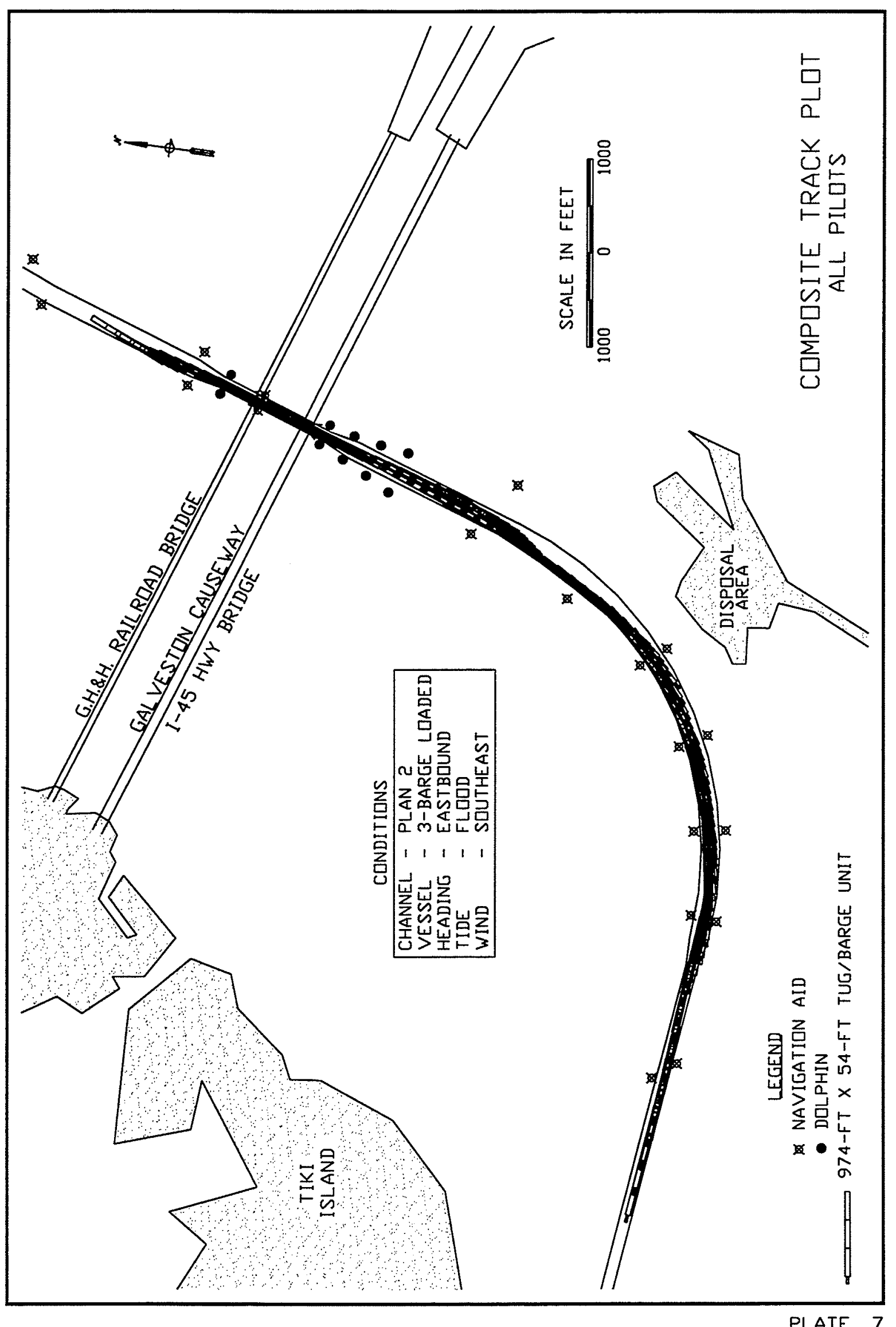




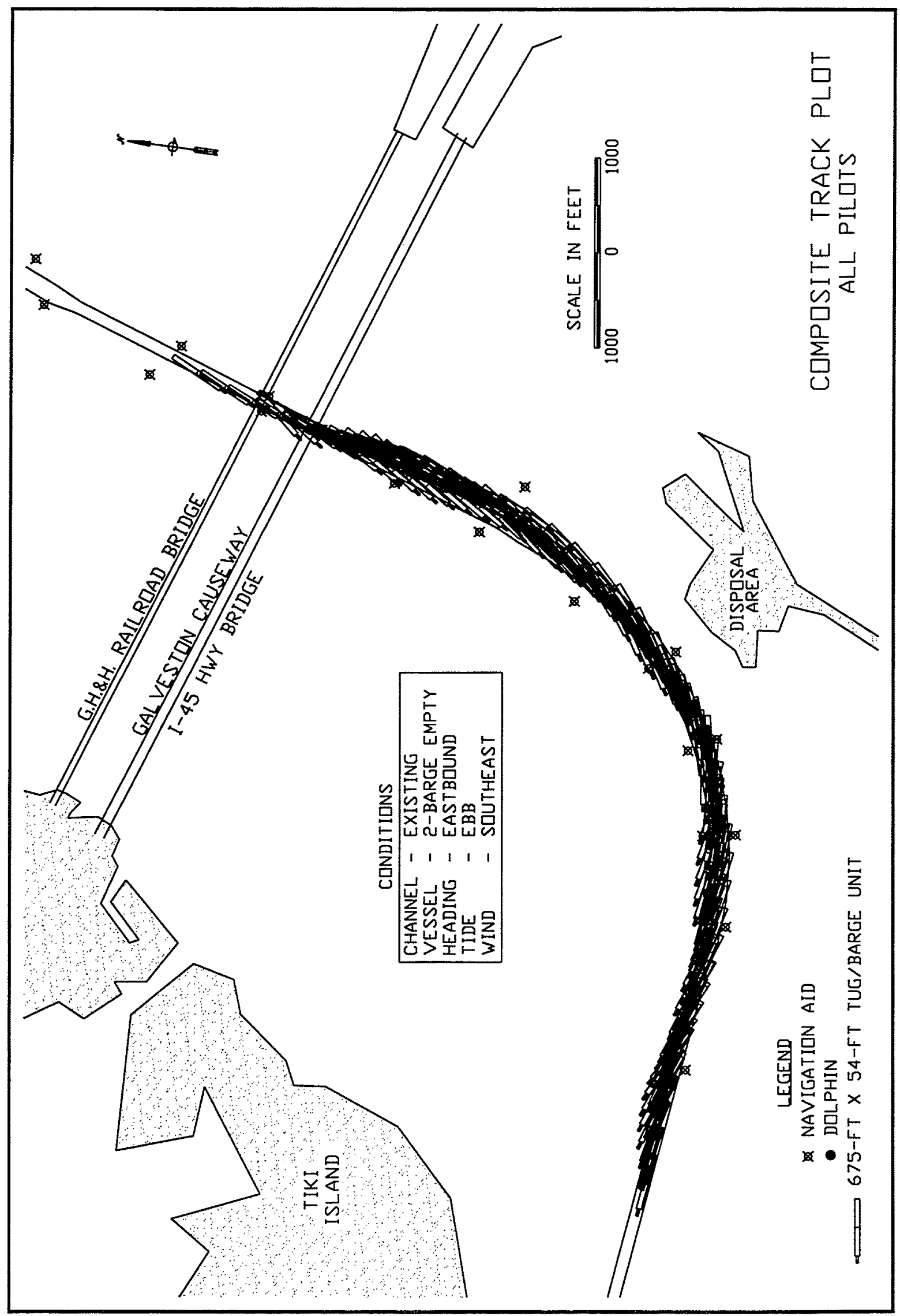

PLATE 8 


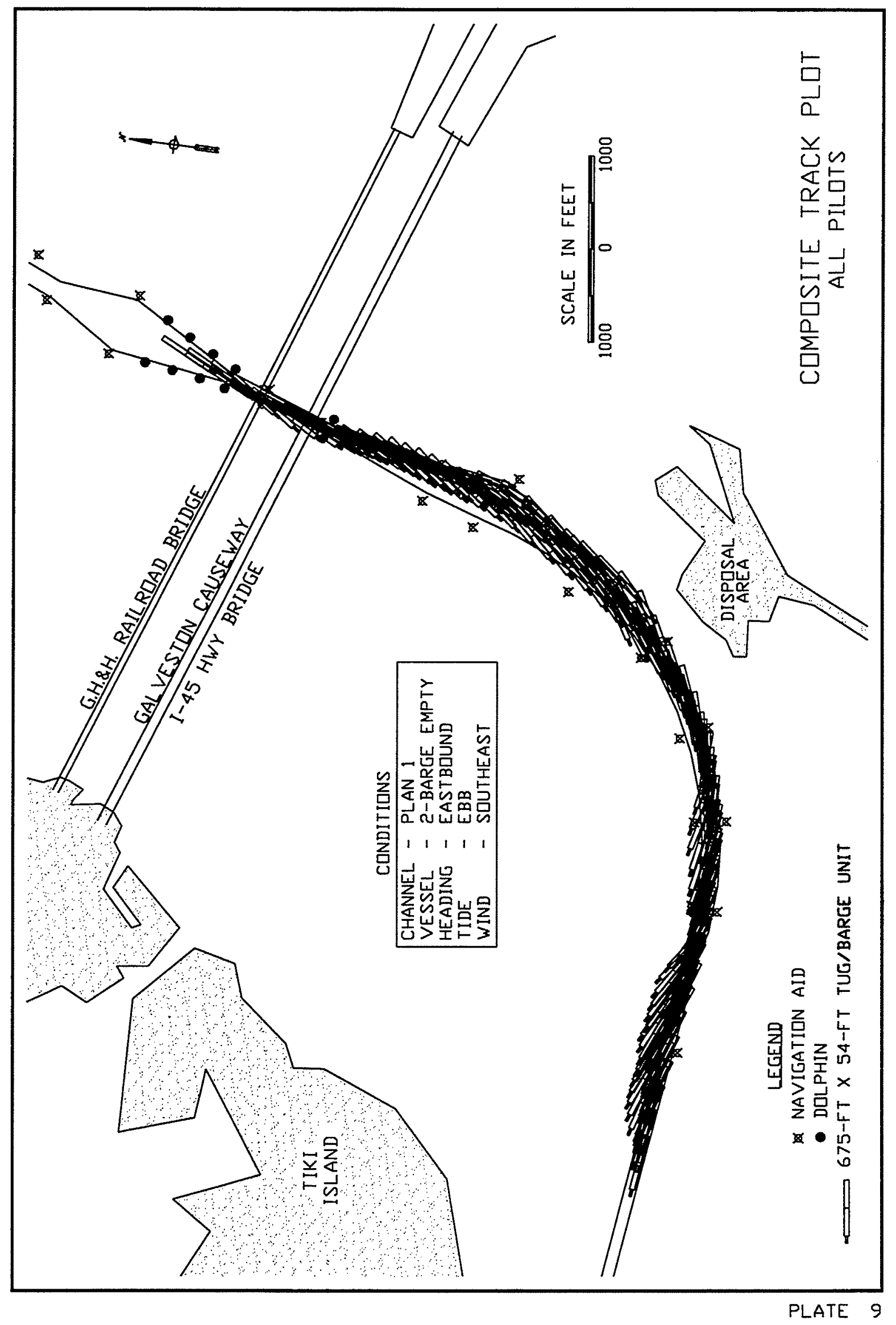




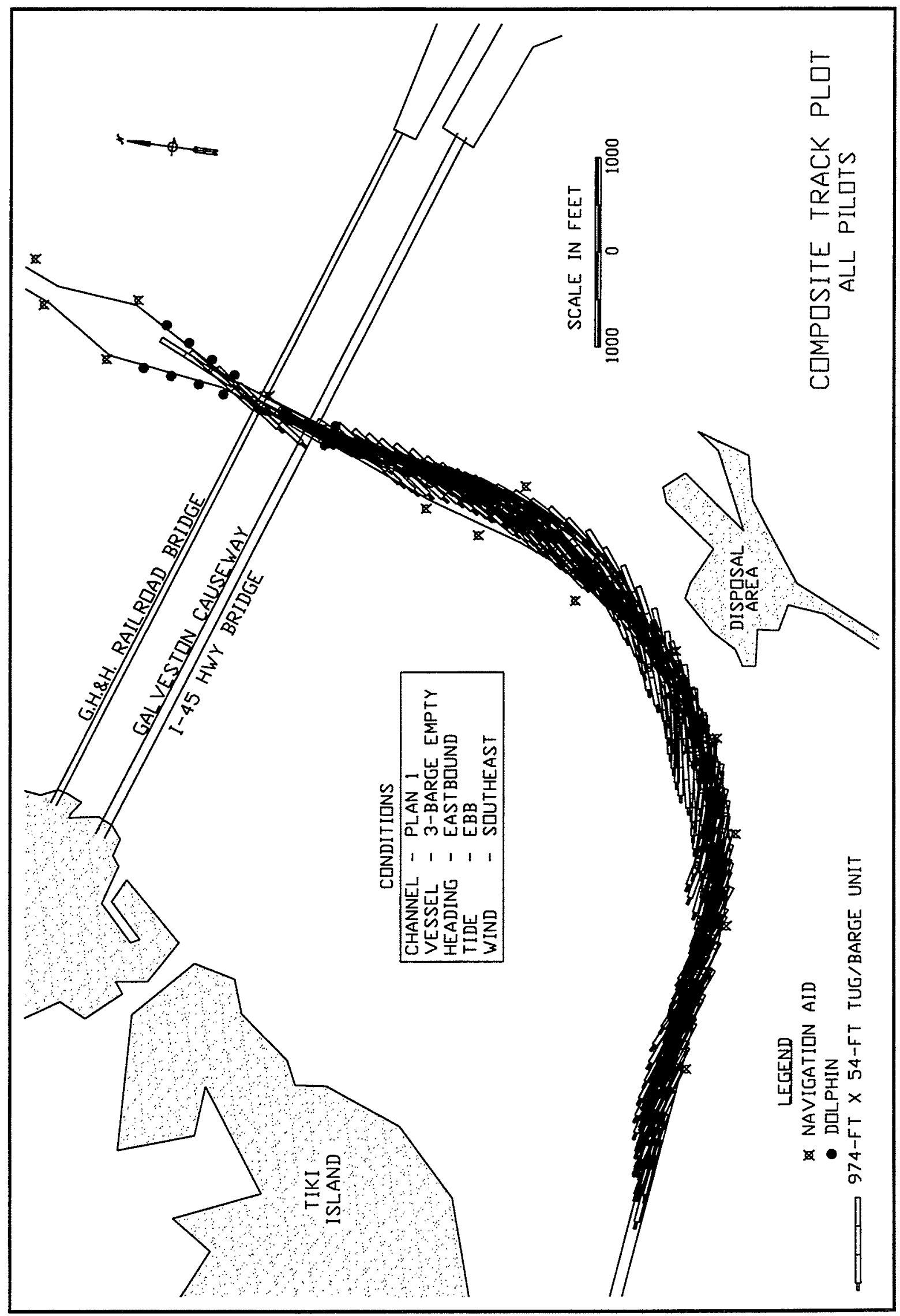

PLATE 10 


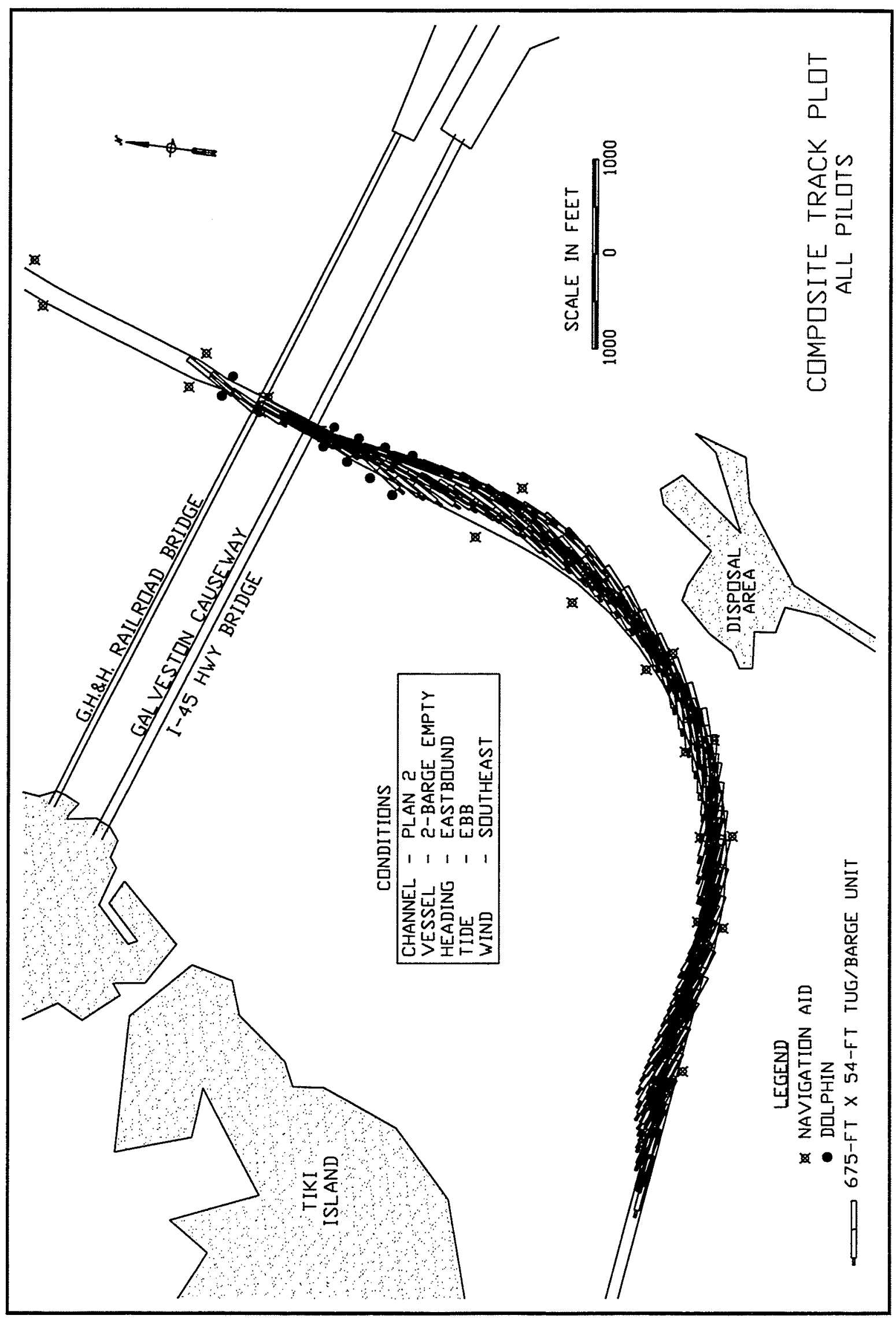

PLATE 11 


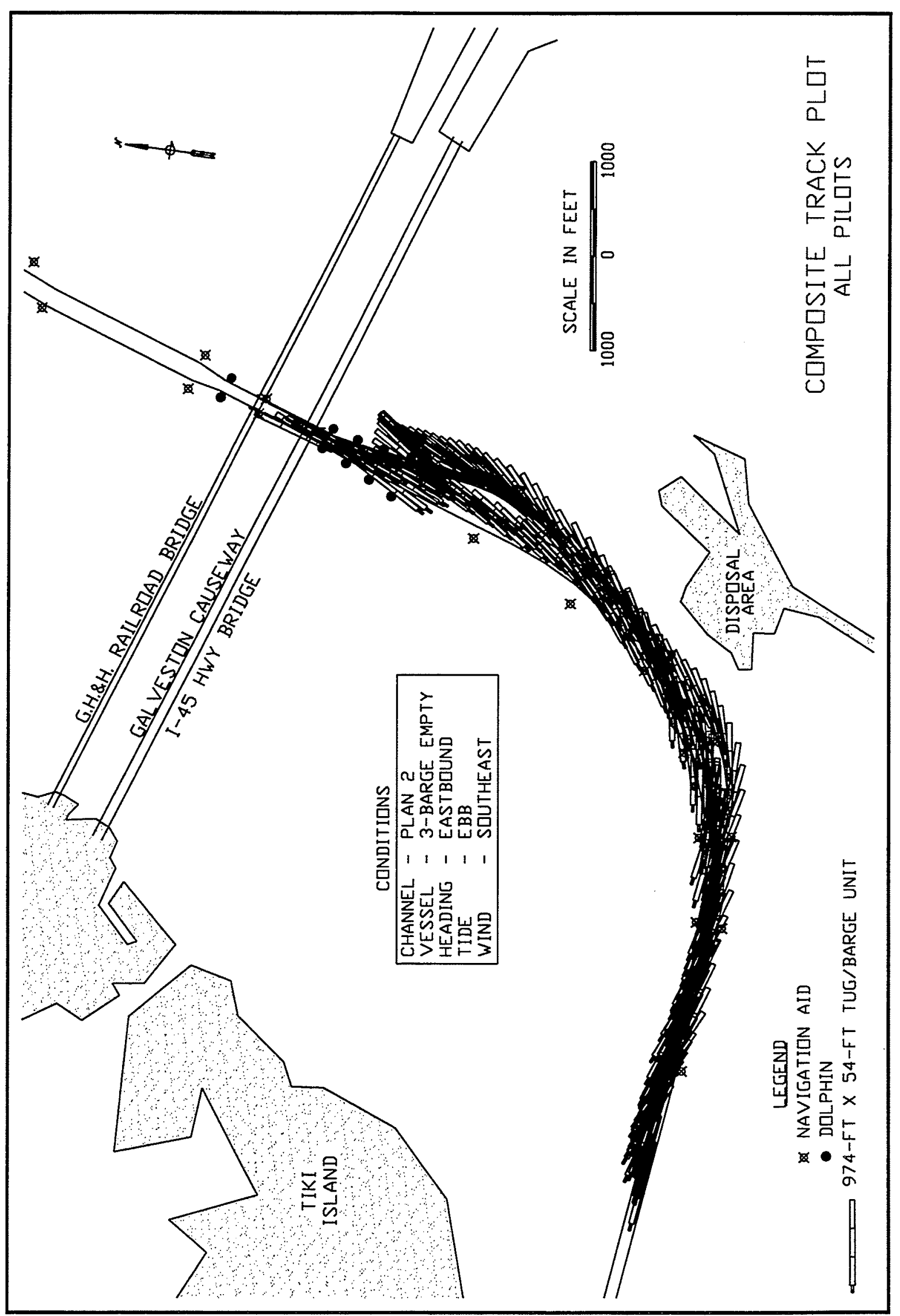

PLATE 12 


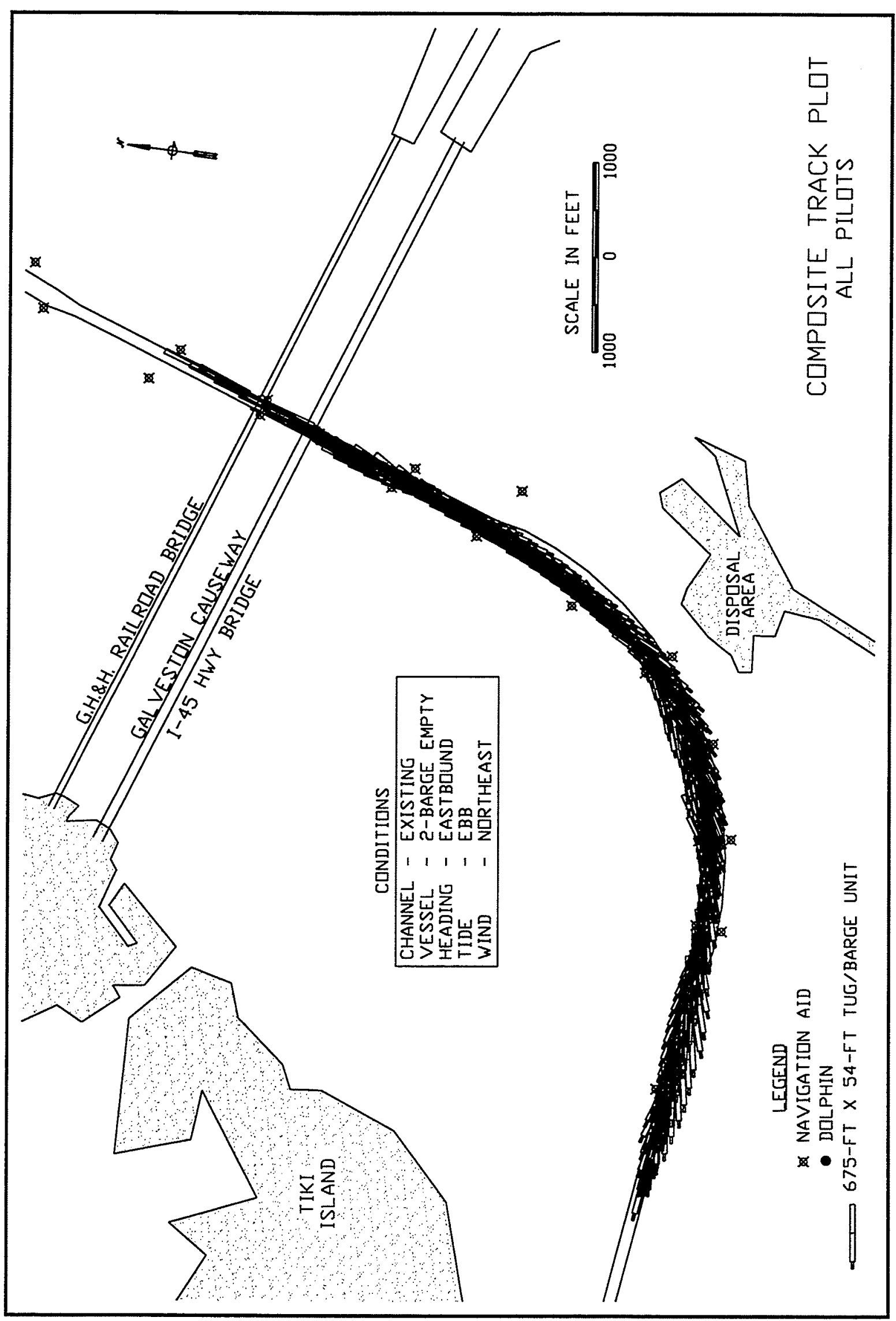




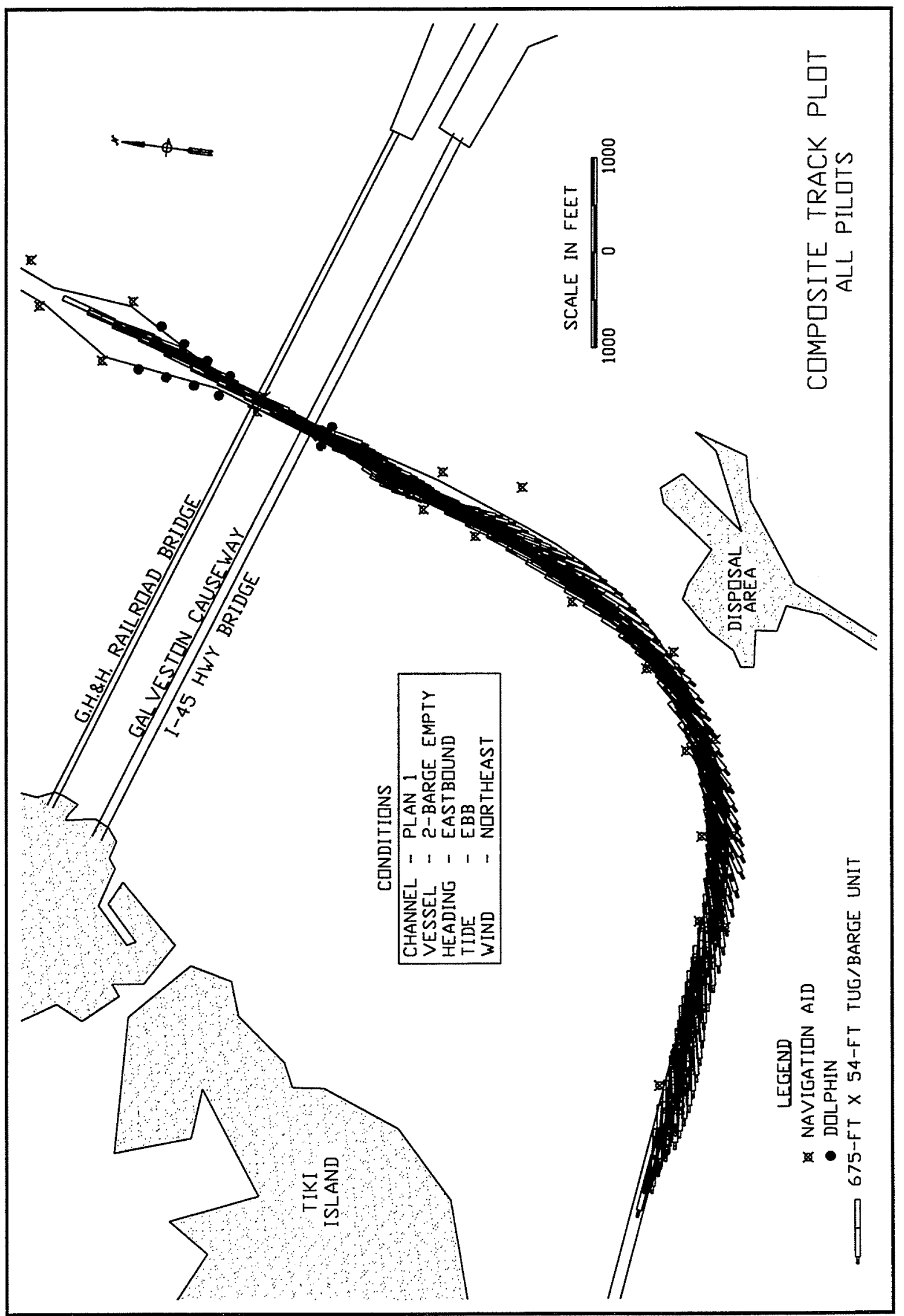

PLATE 14 


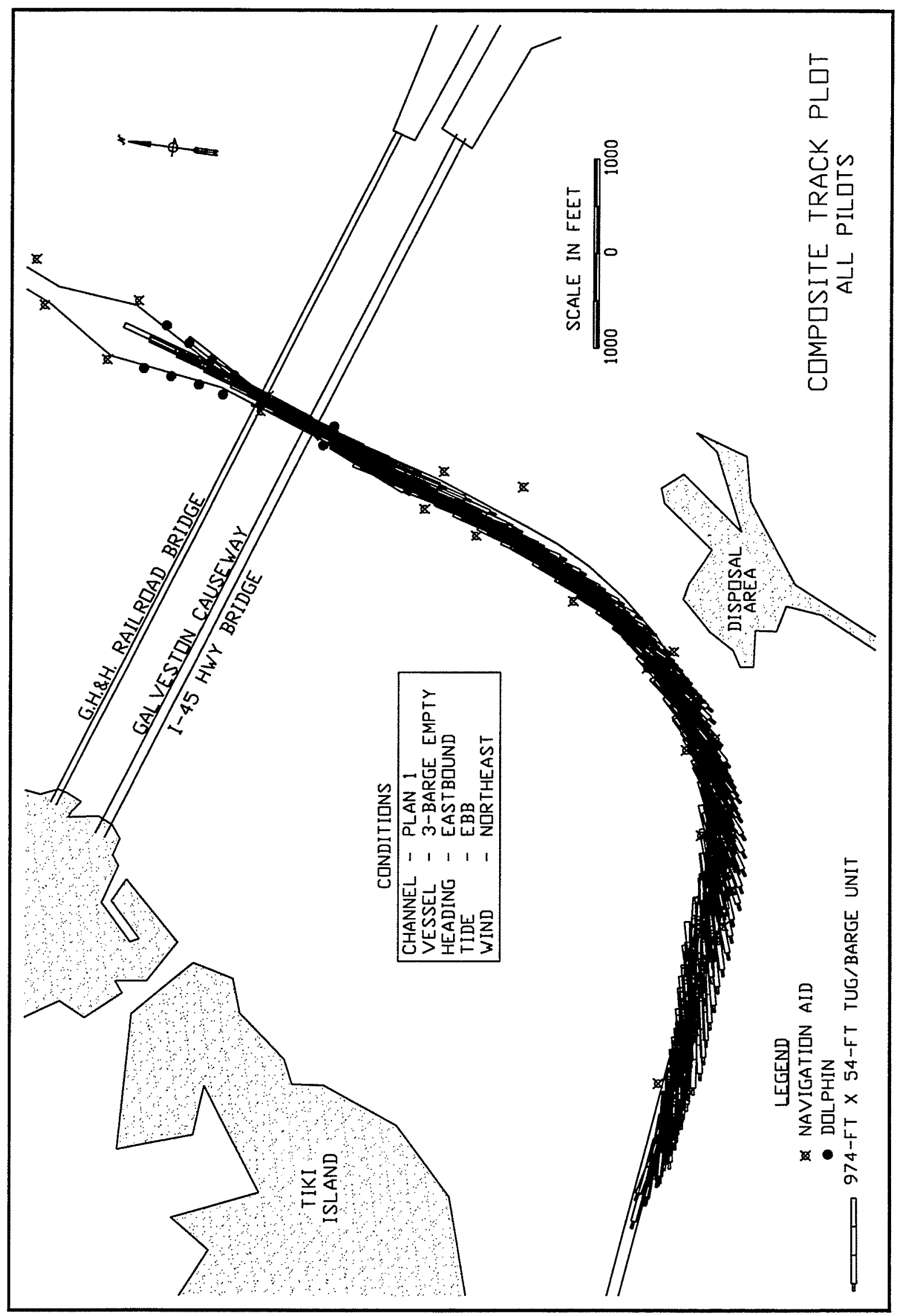

PLATE 15 


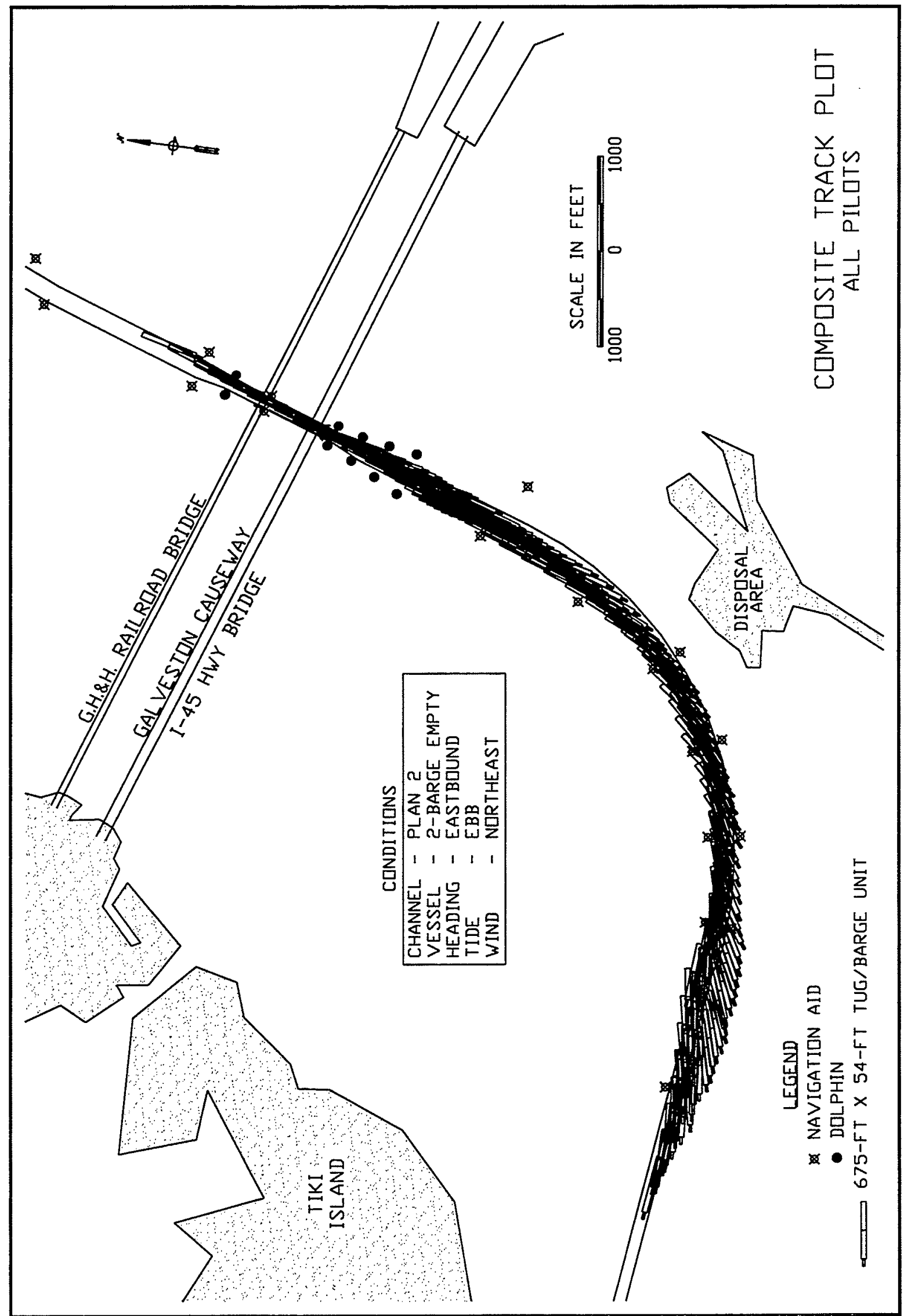

PLATE 16 


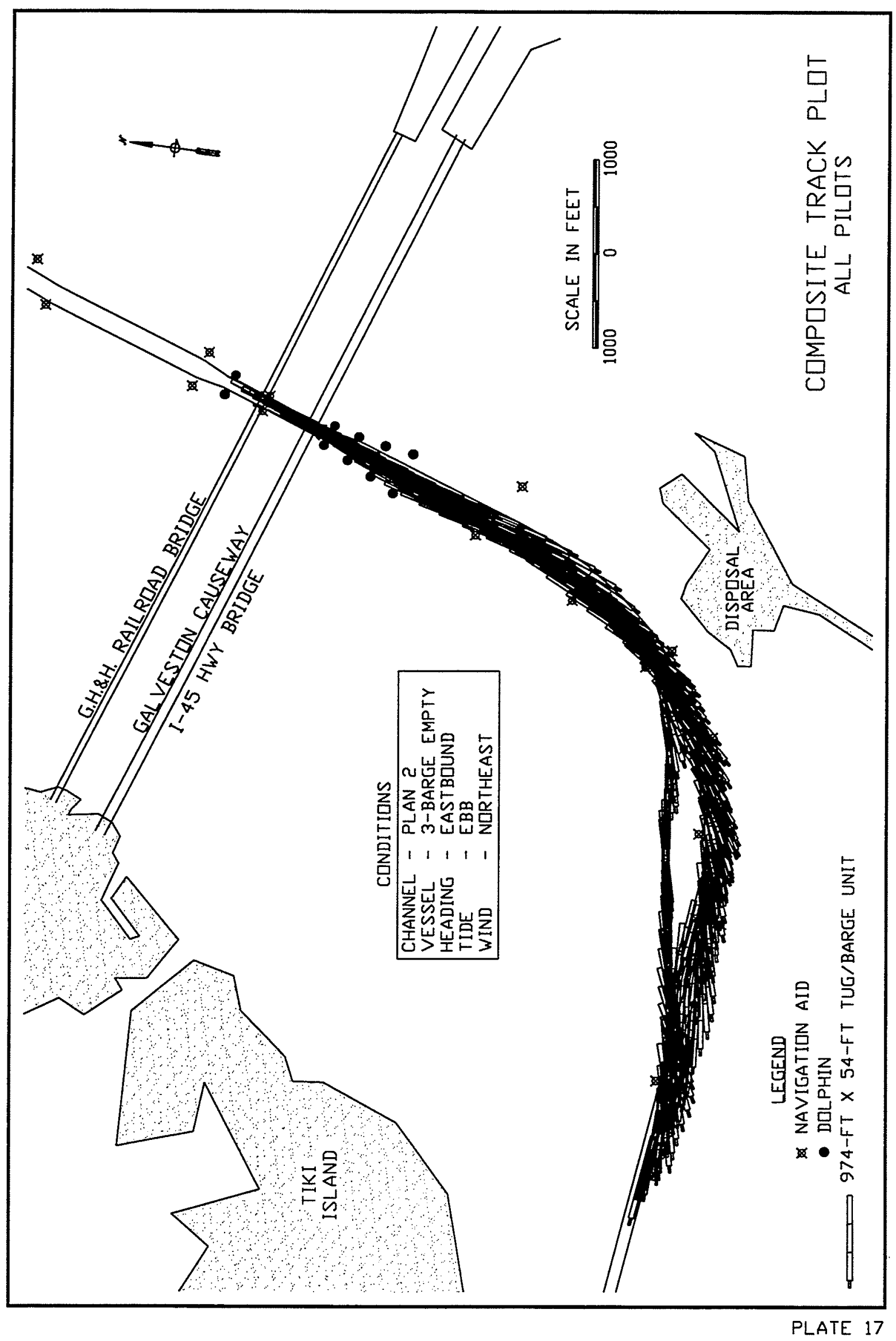




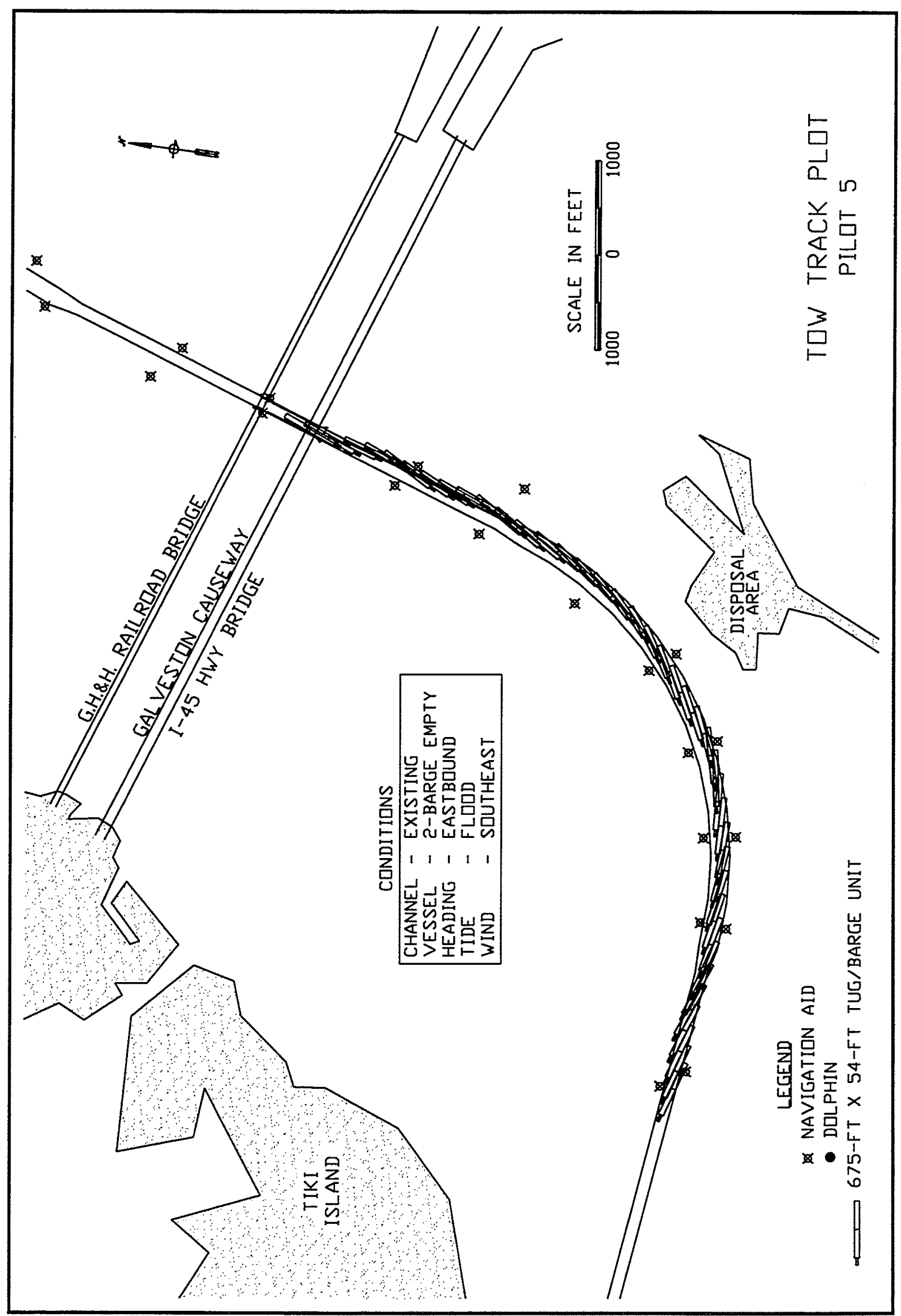

PLATE 18 


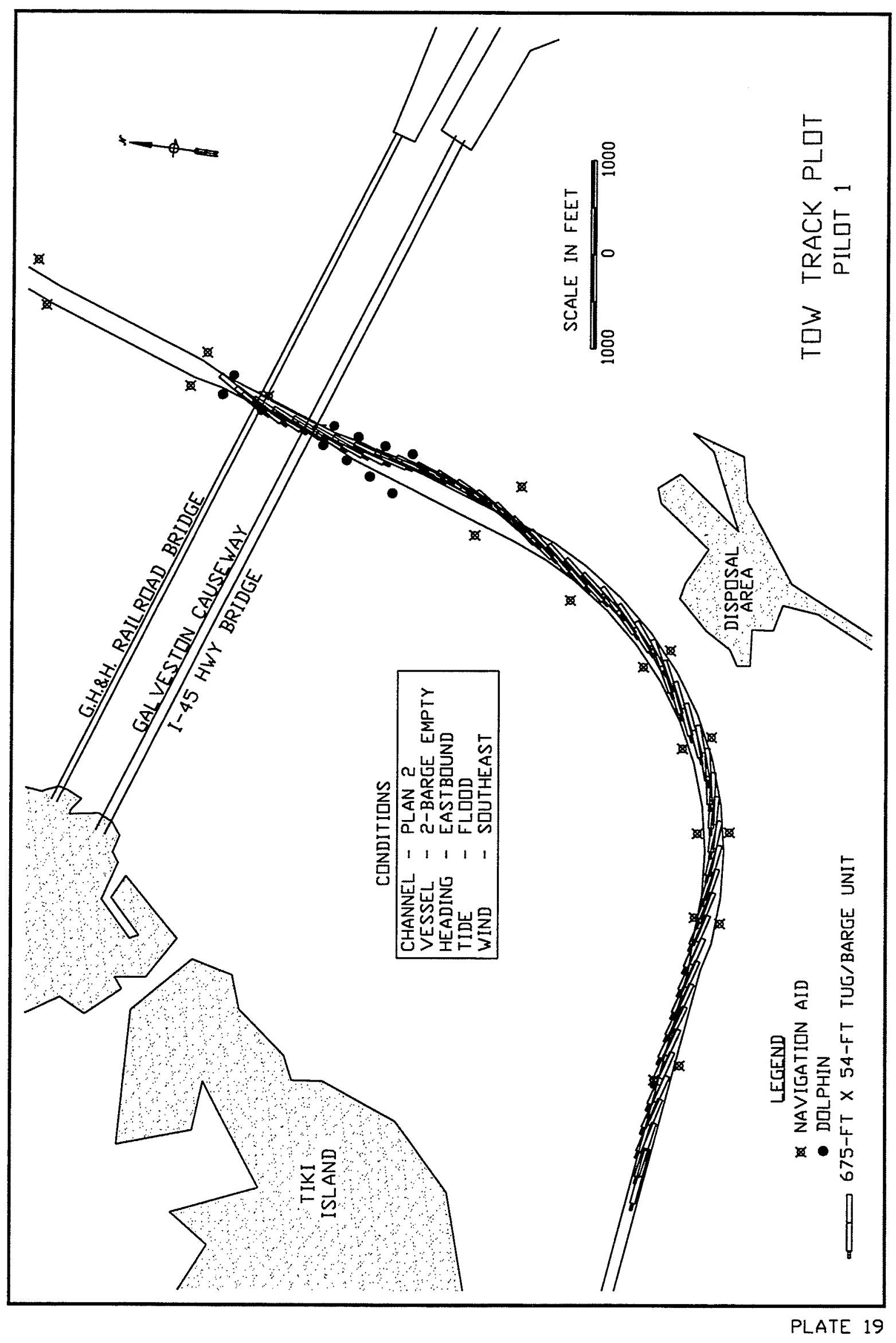




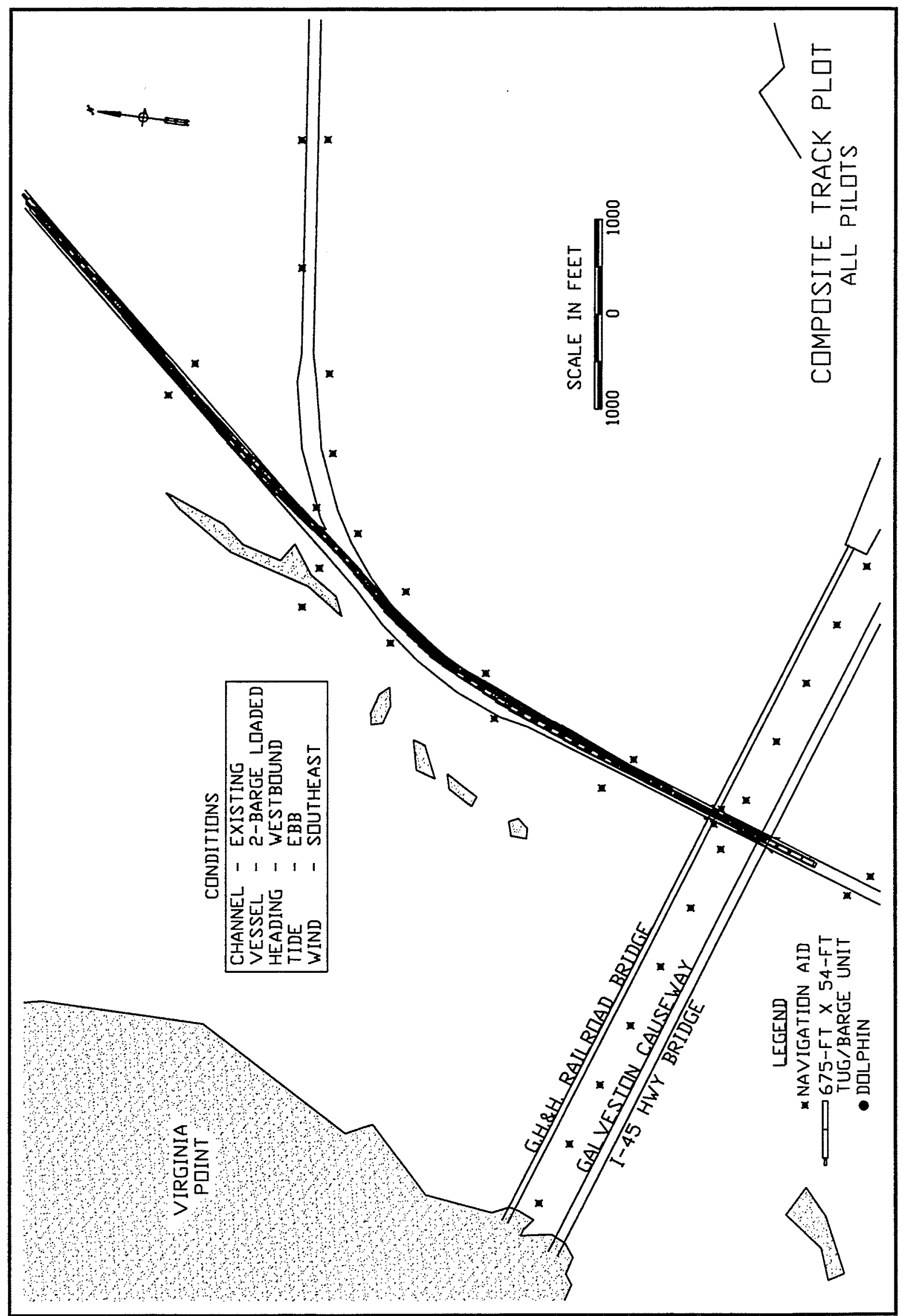

PLATE 20 


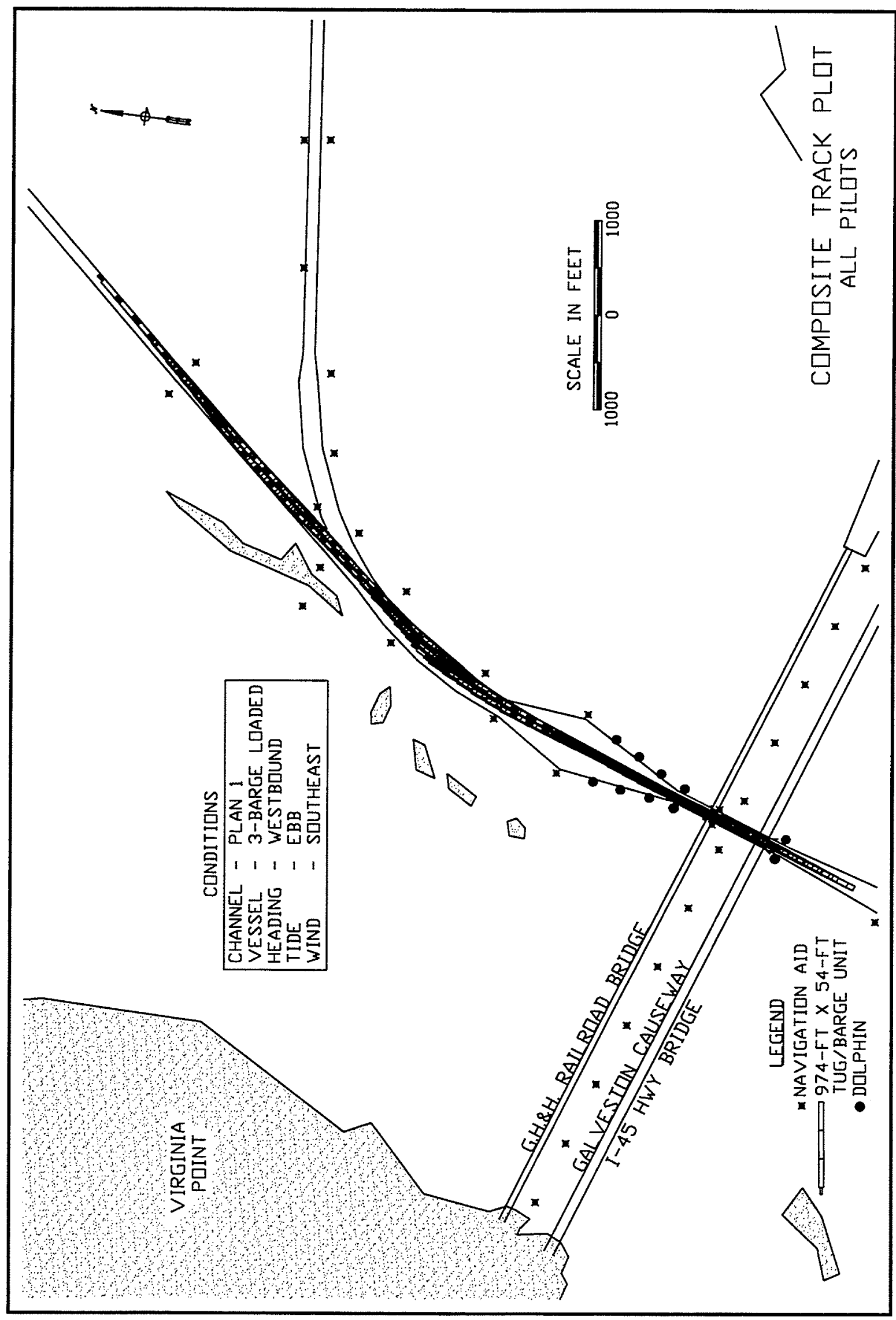

PLATE 21 


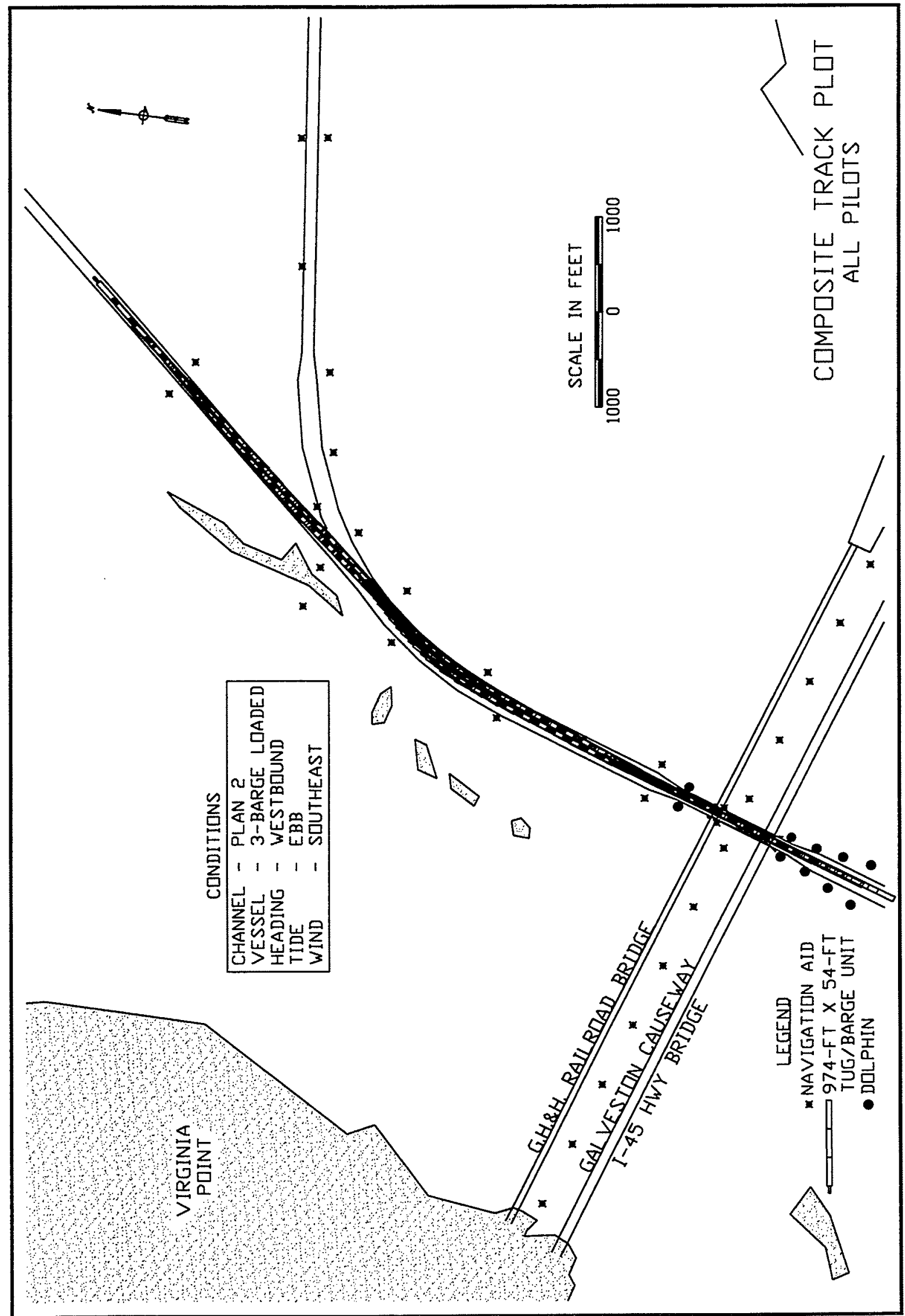

PLATE 22 


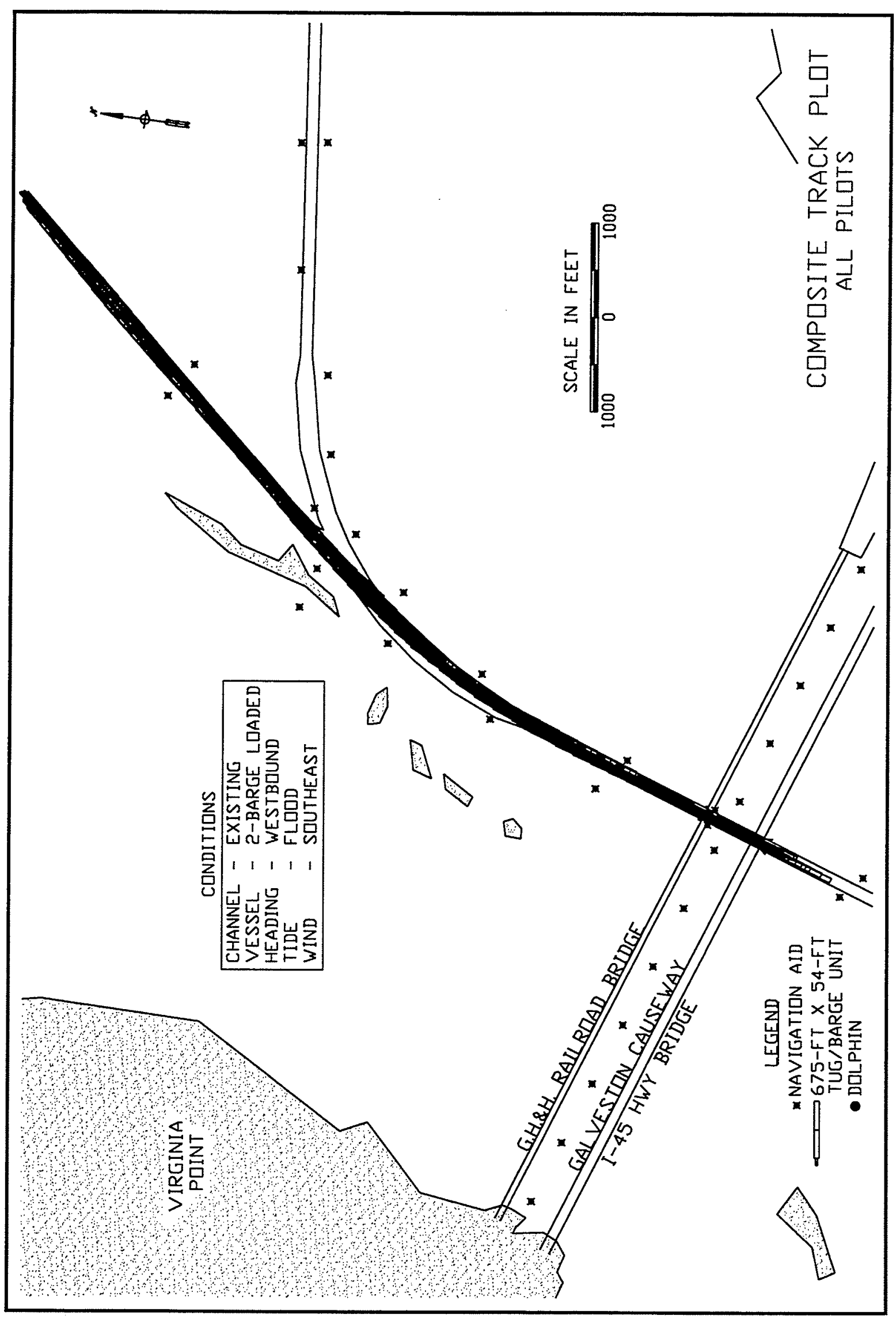

PLATE 23 


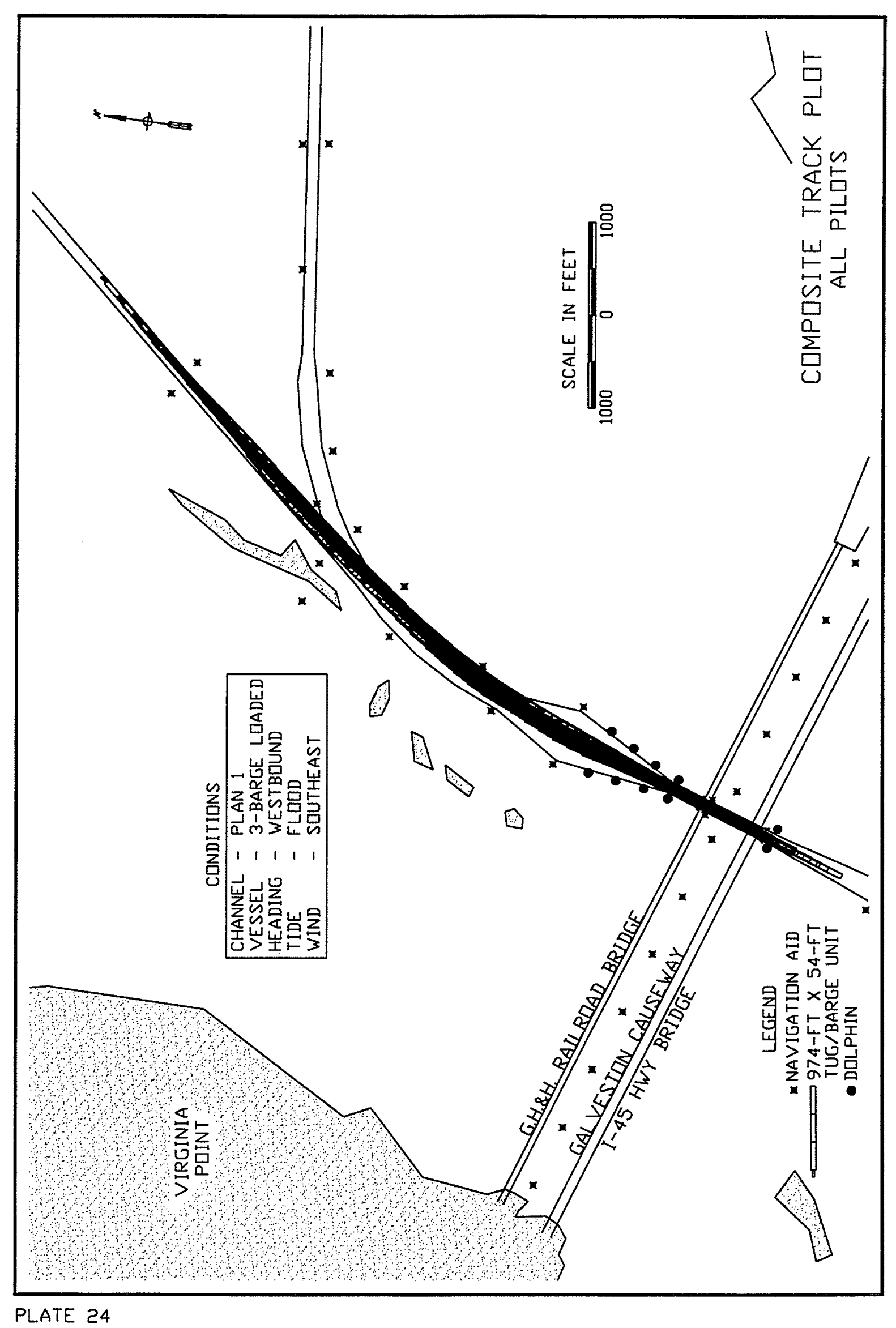




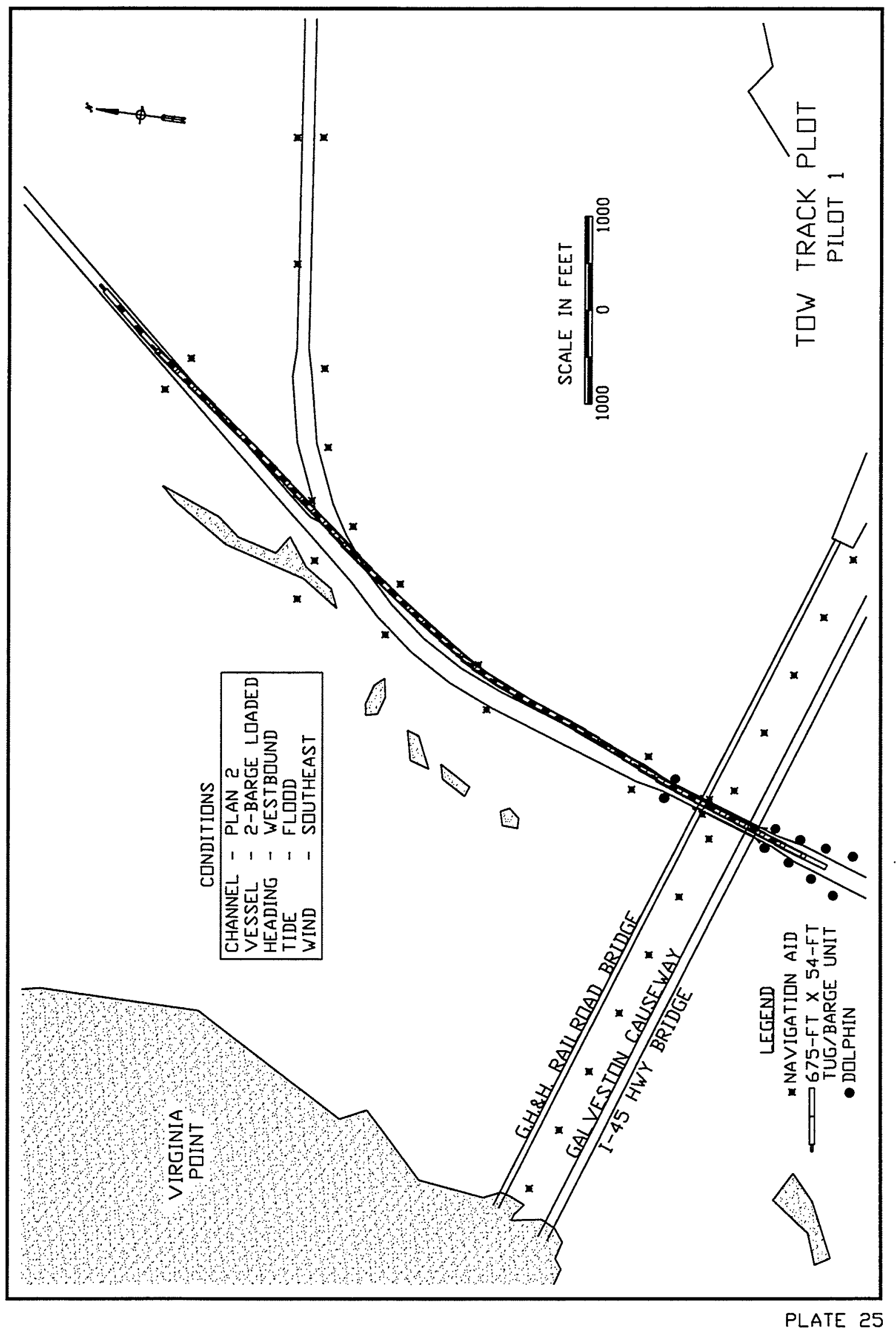




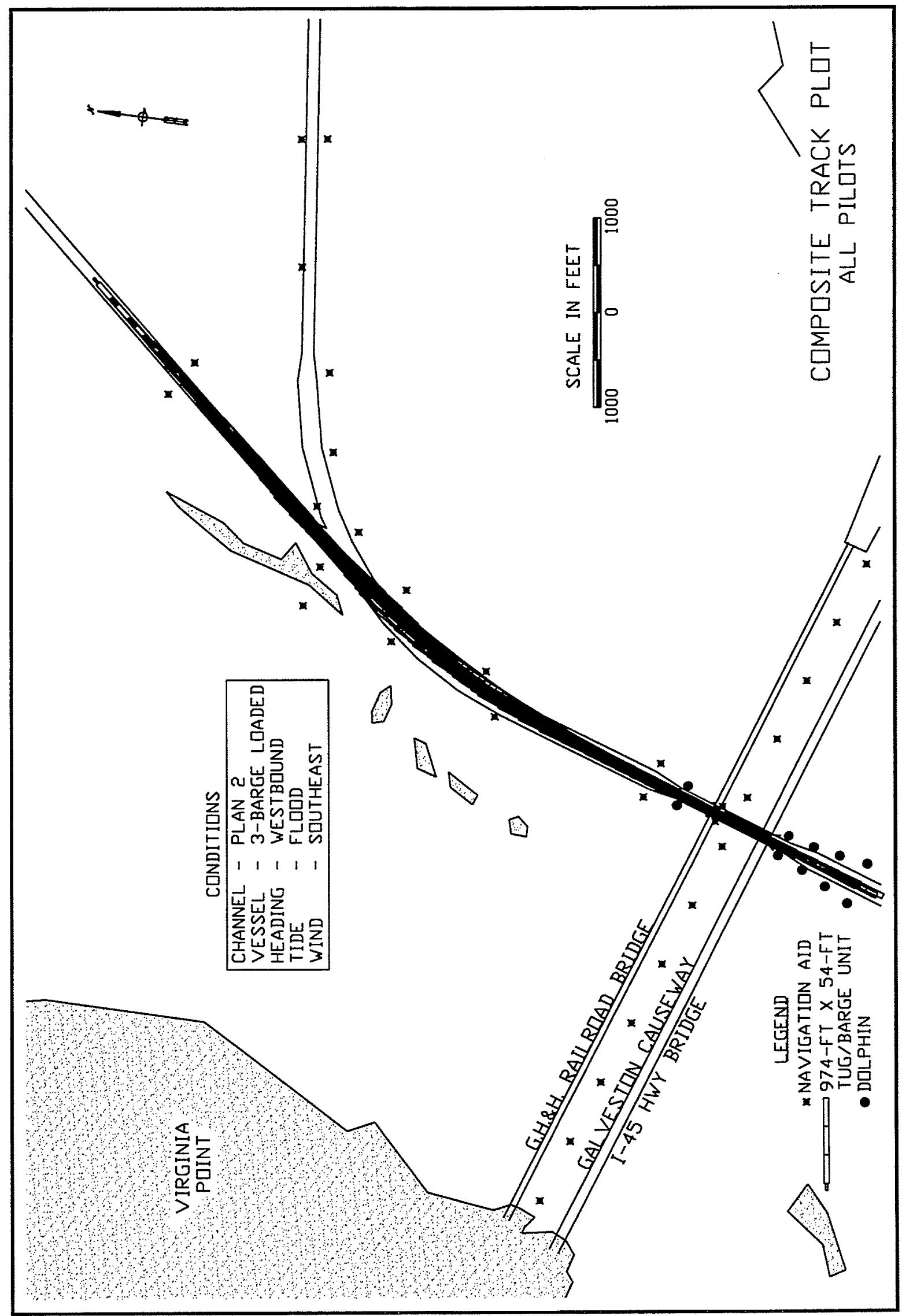

PLATE 26 


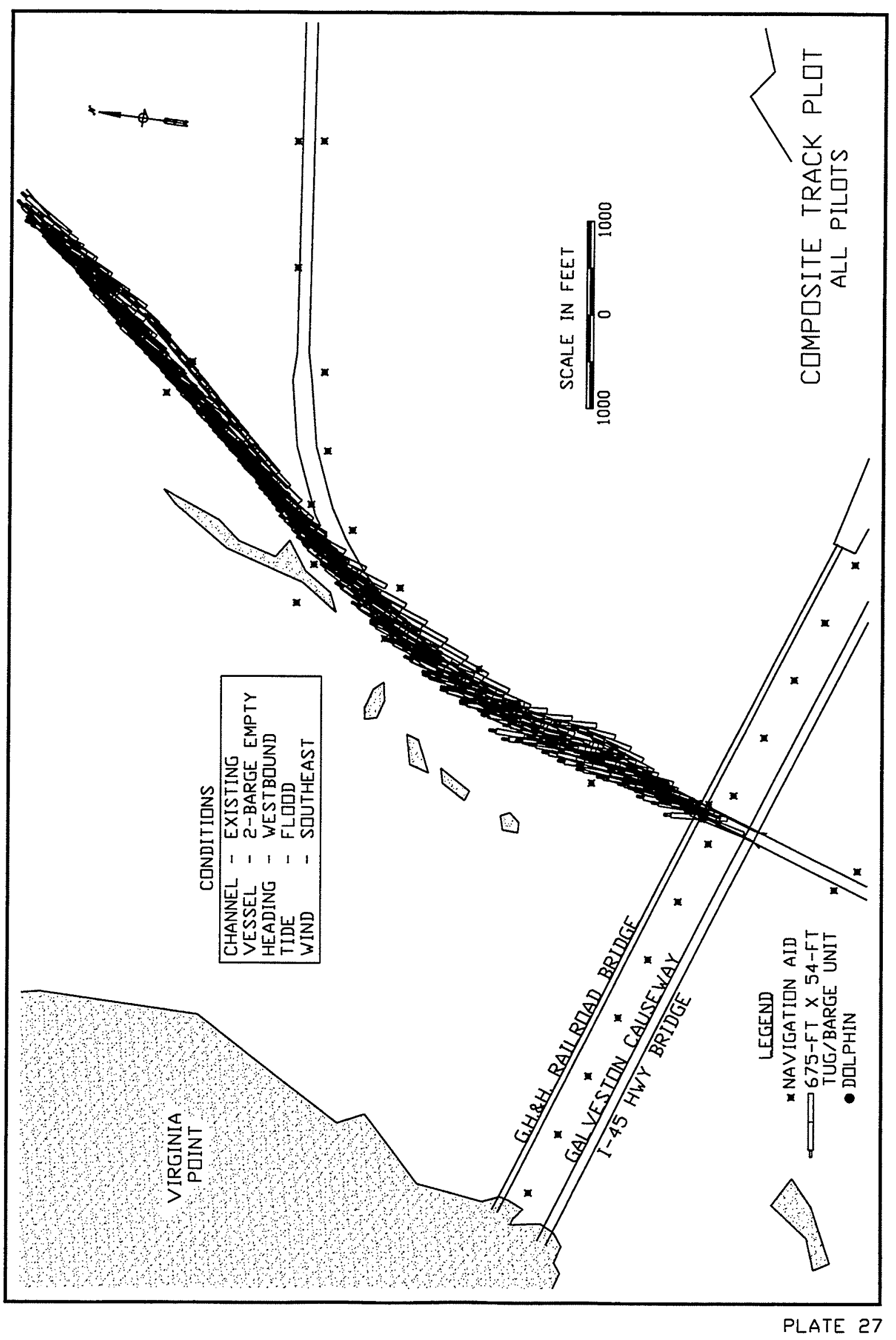




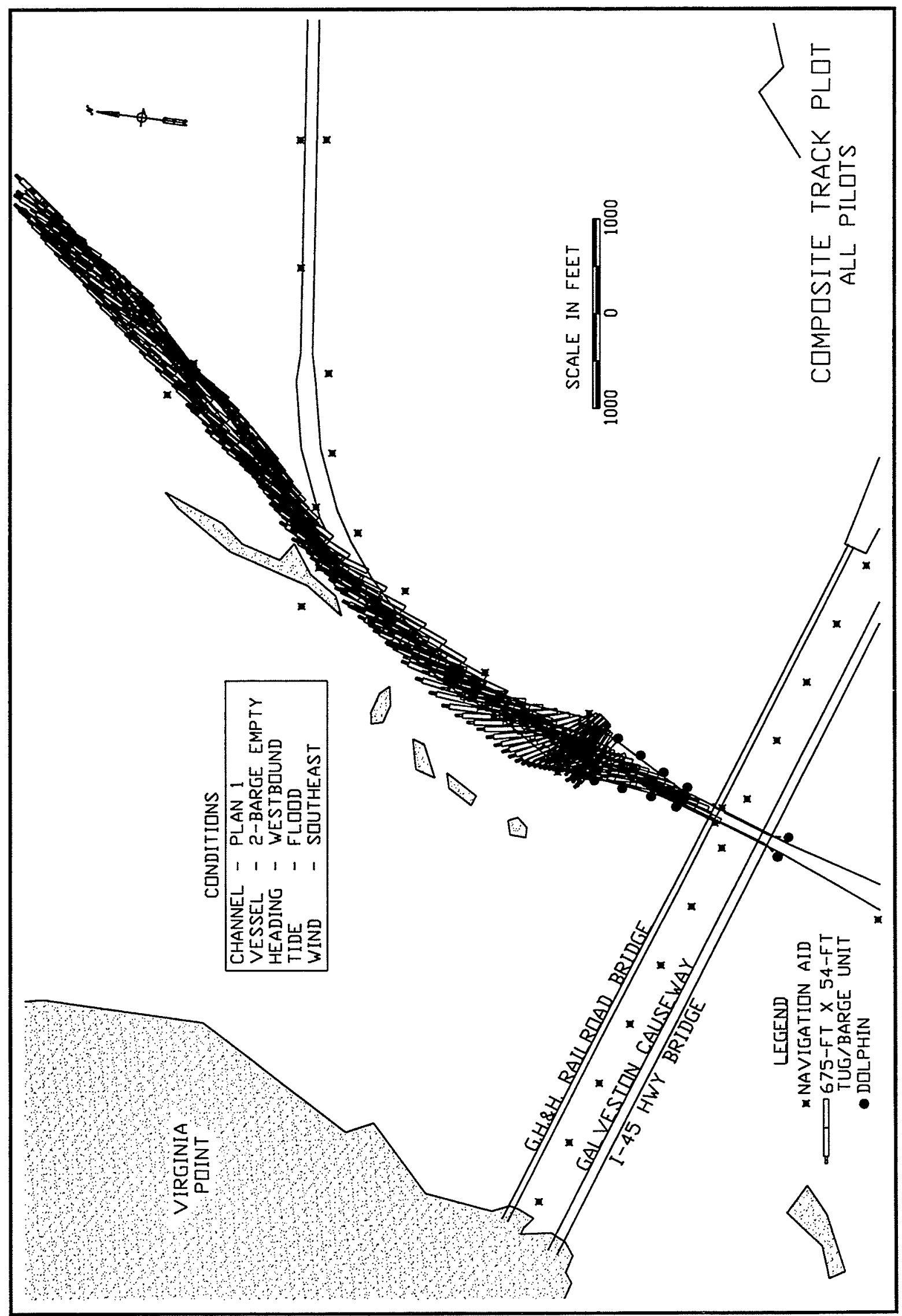

PLATE 28 


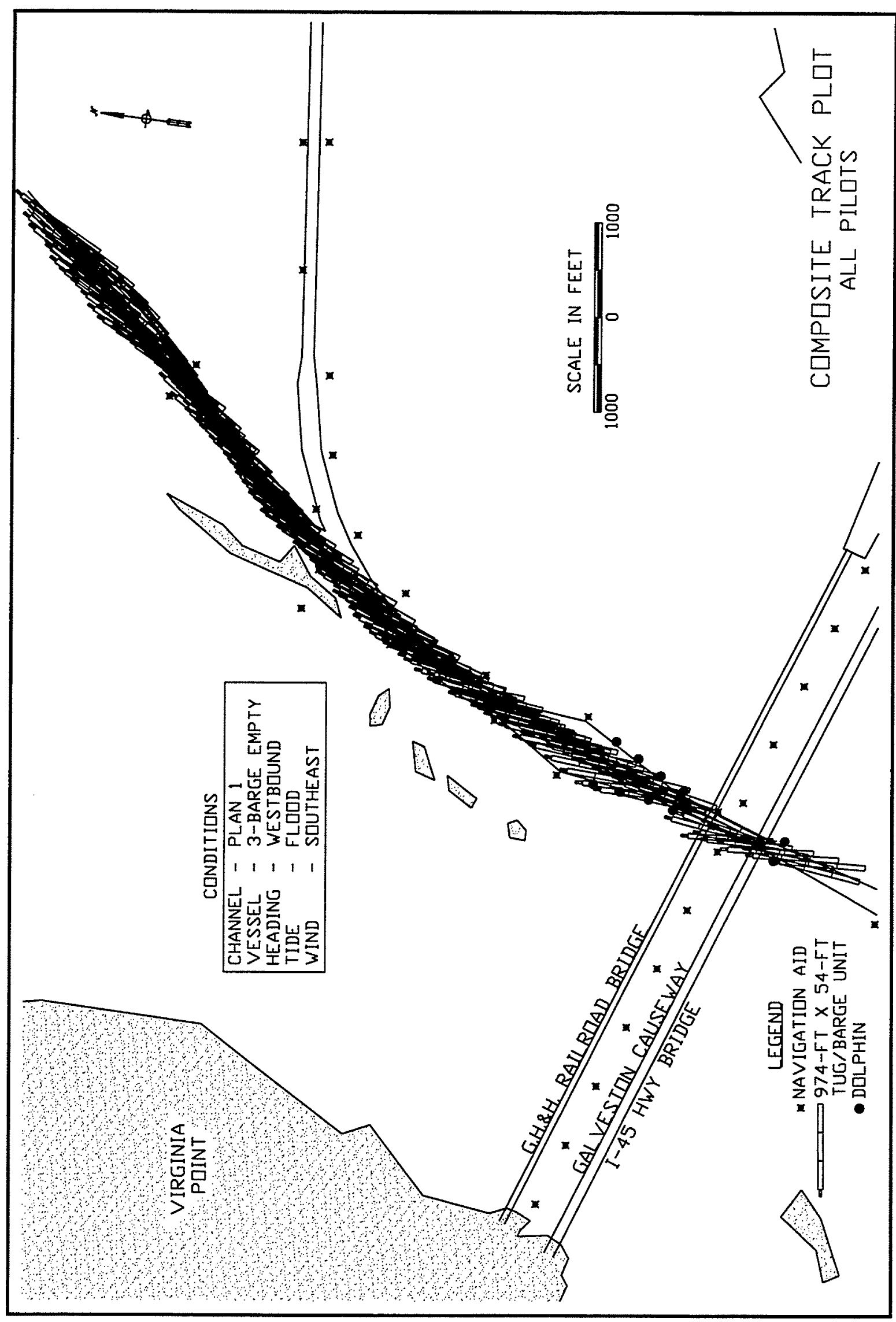

PLATE 29 


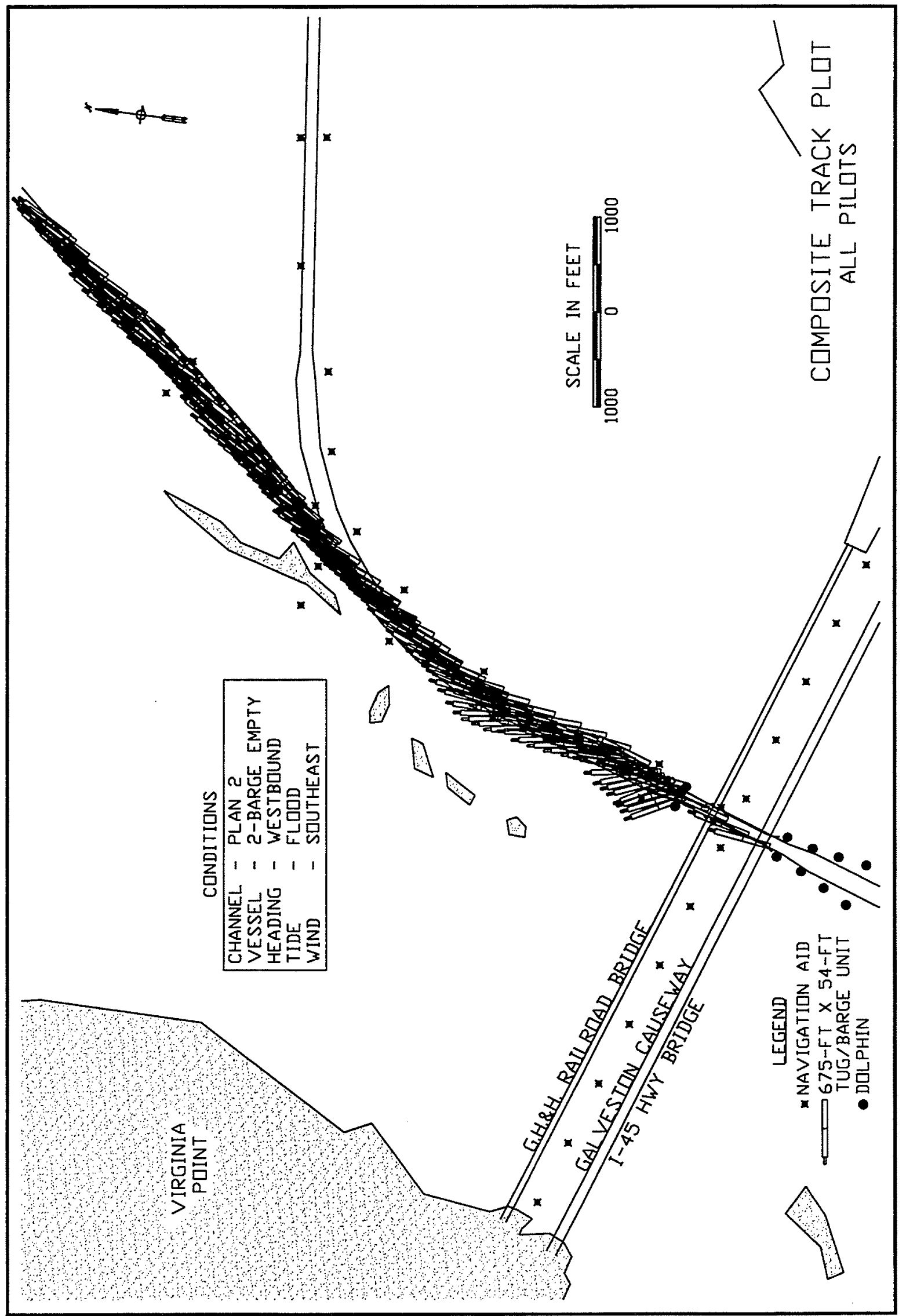

PLATE 30 


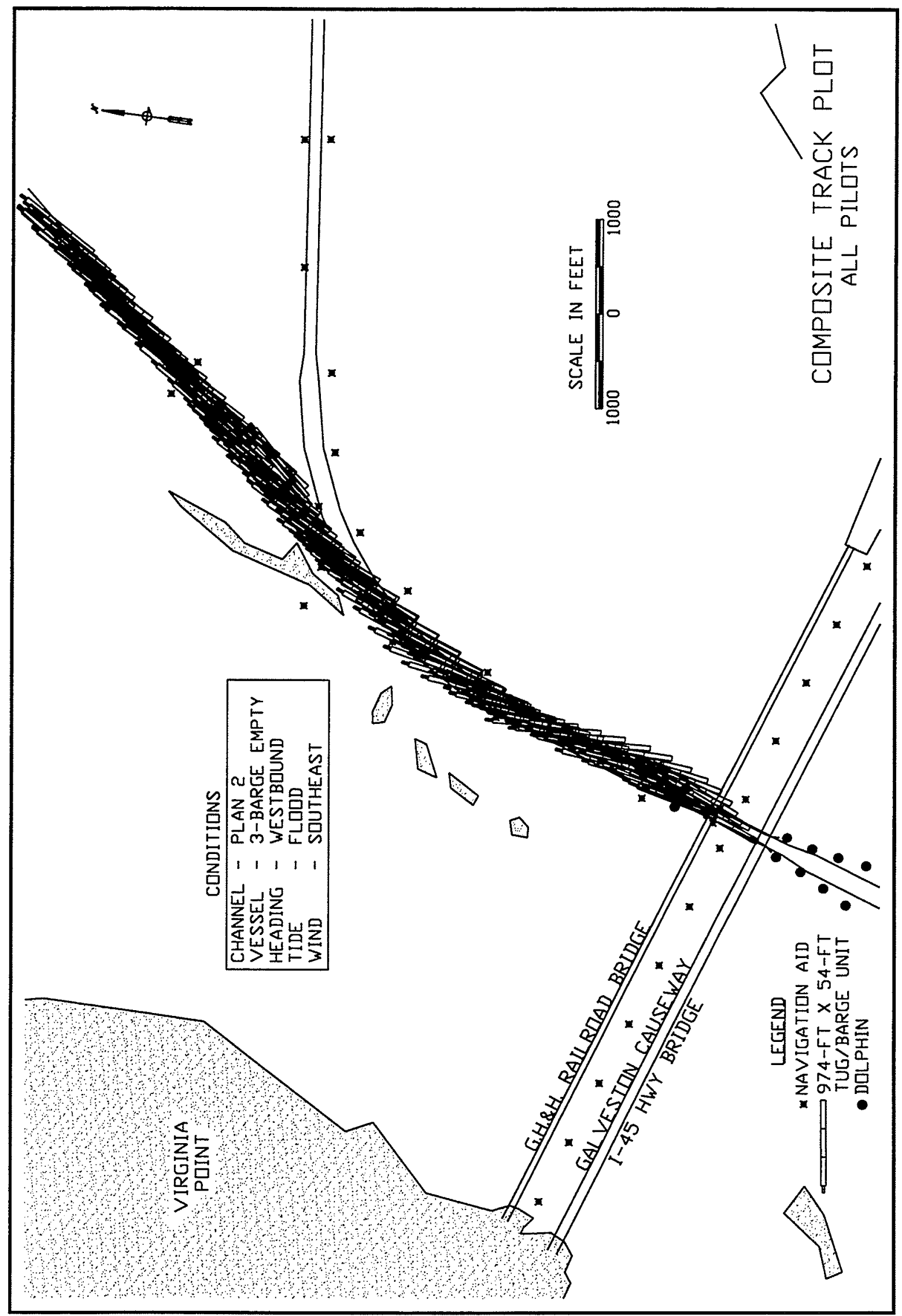

PLATE 31 


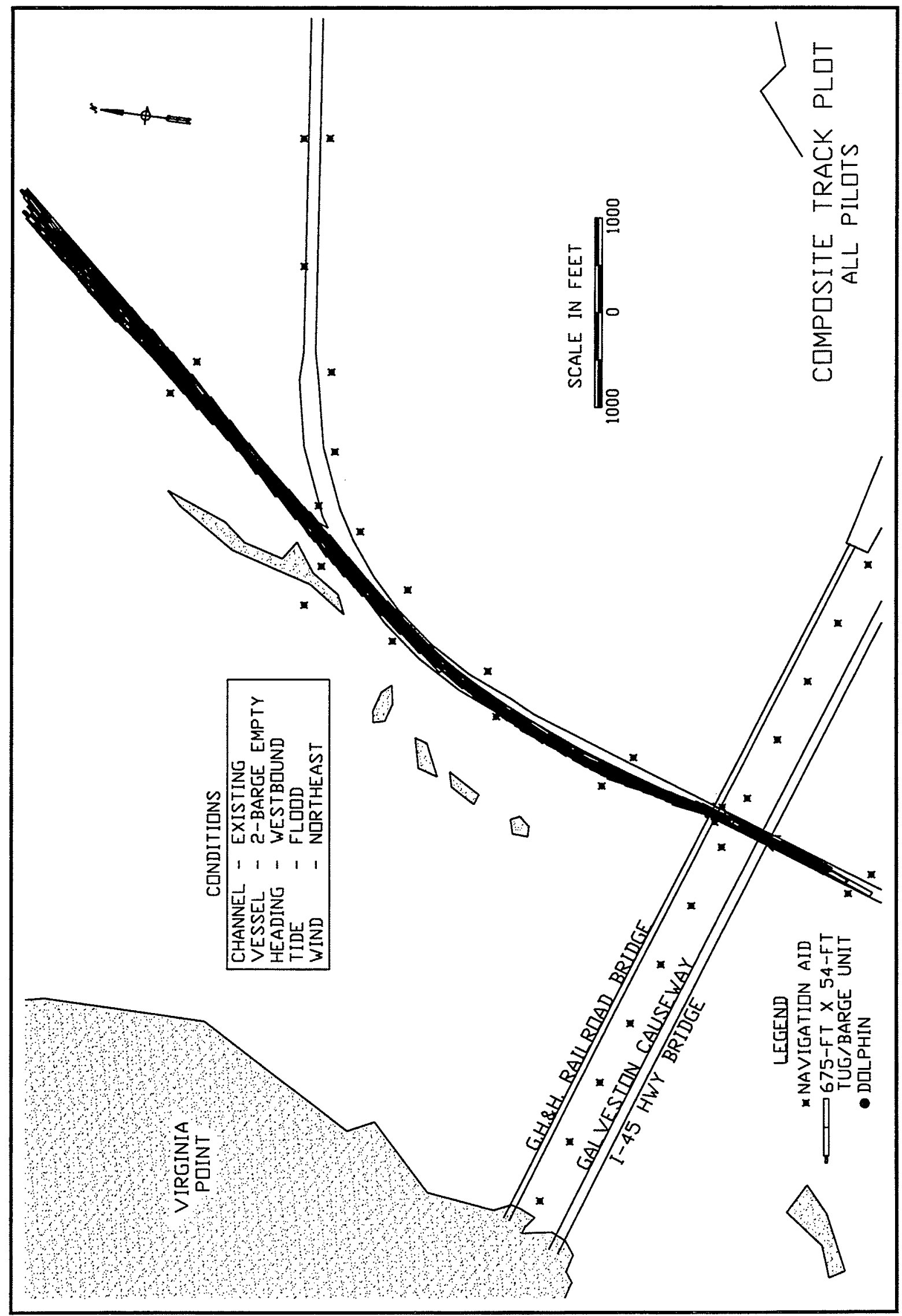

PLATE 32 


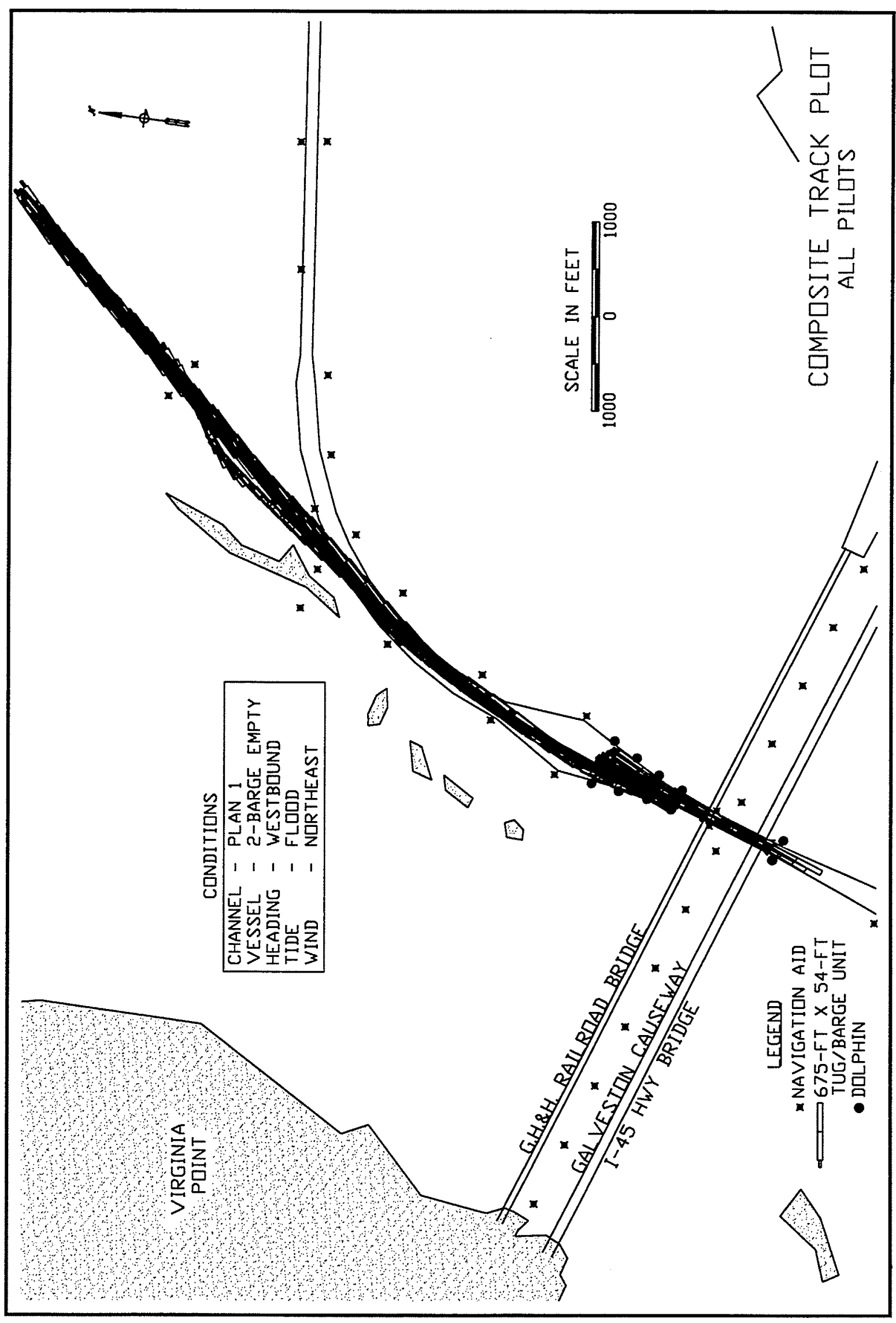

PLATE 33 


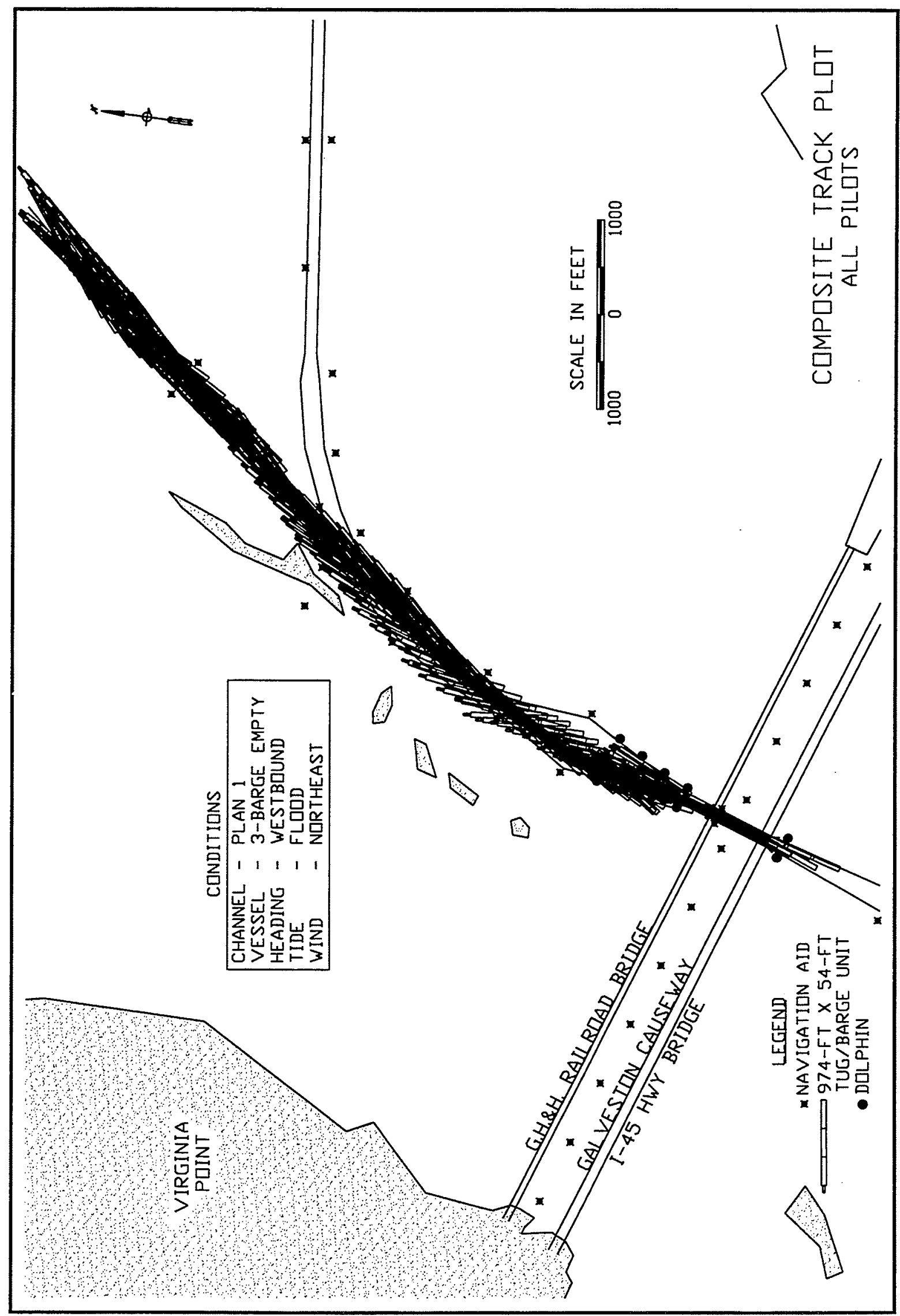

PLATE 34 


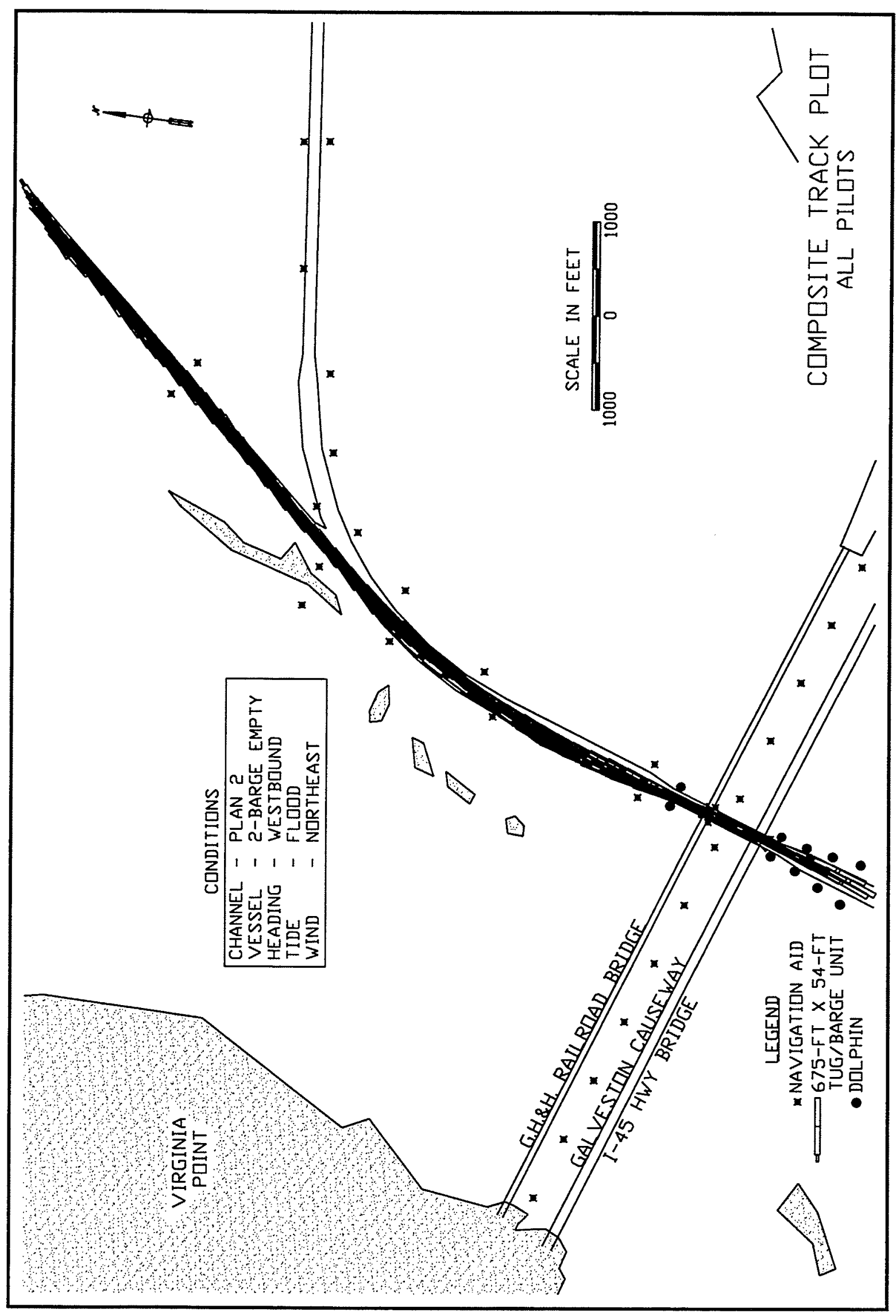

PLATE 35 


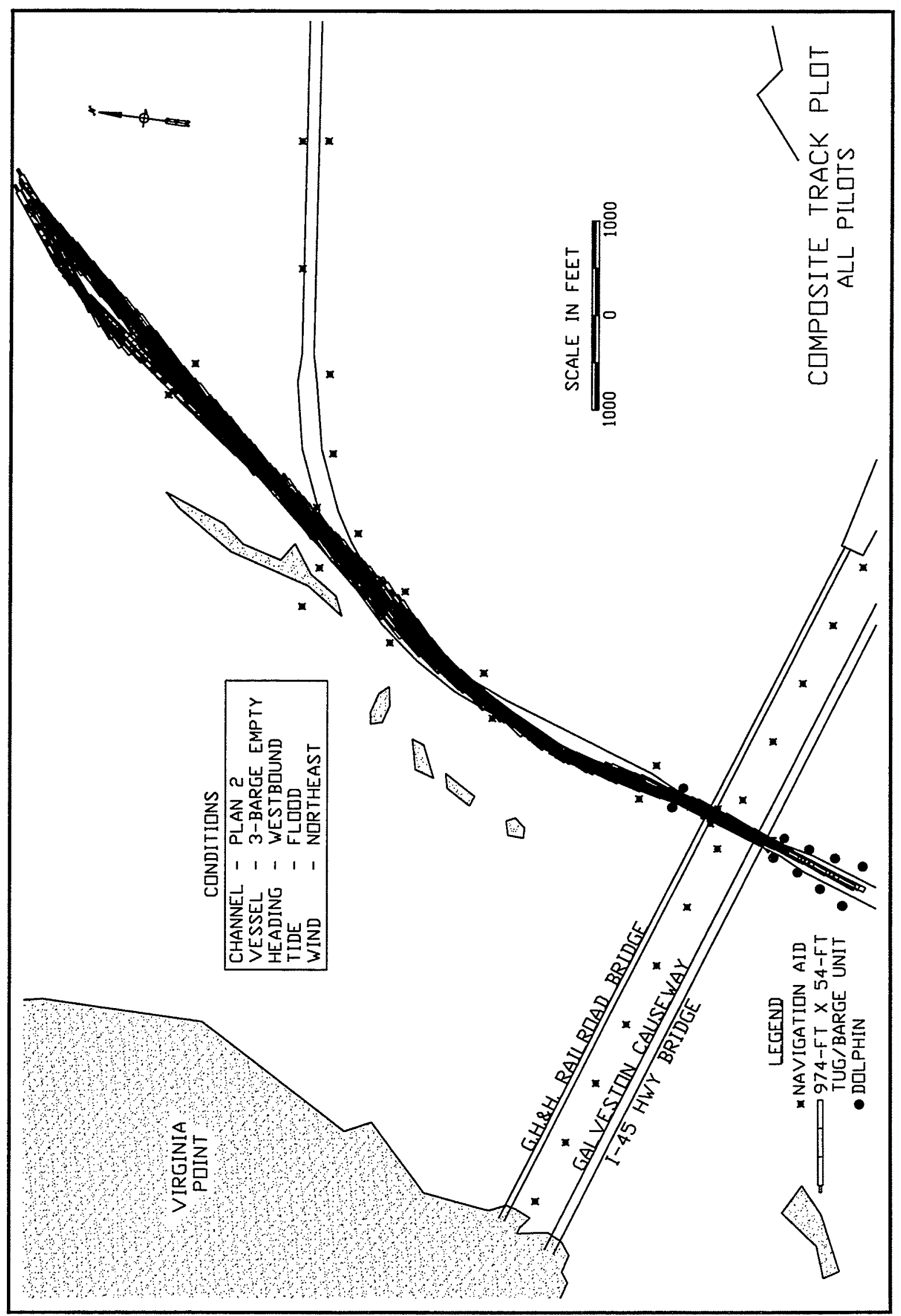

PLATE 36 


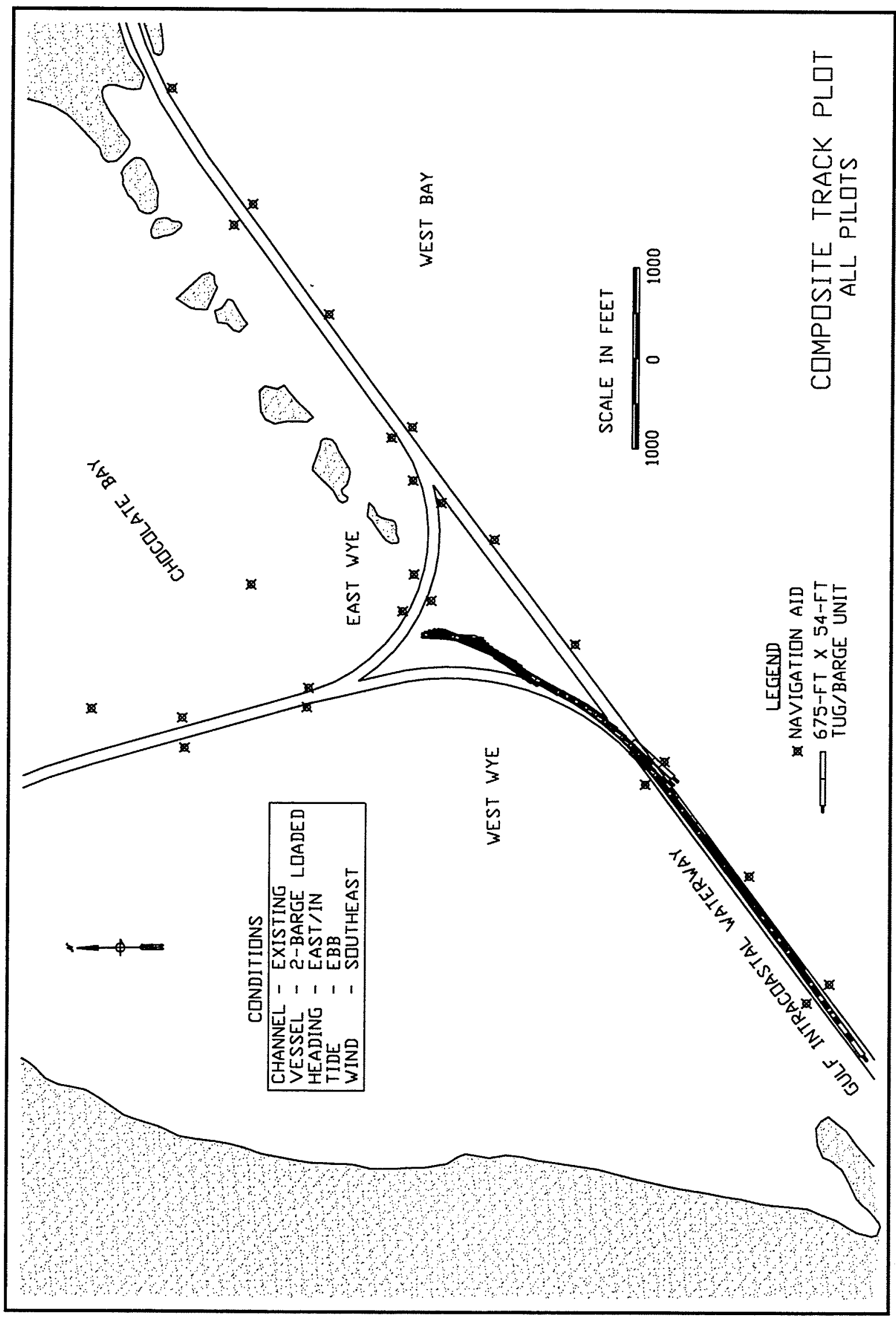

Plate 37 


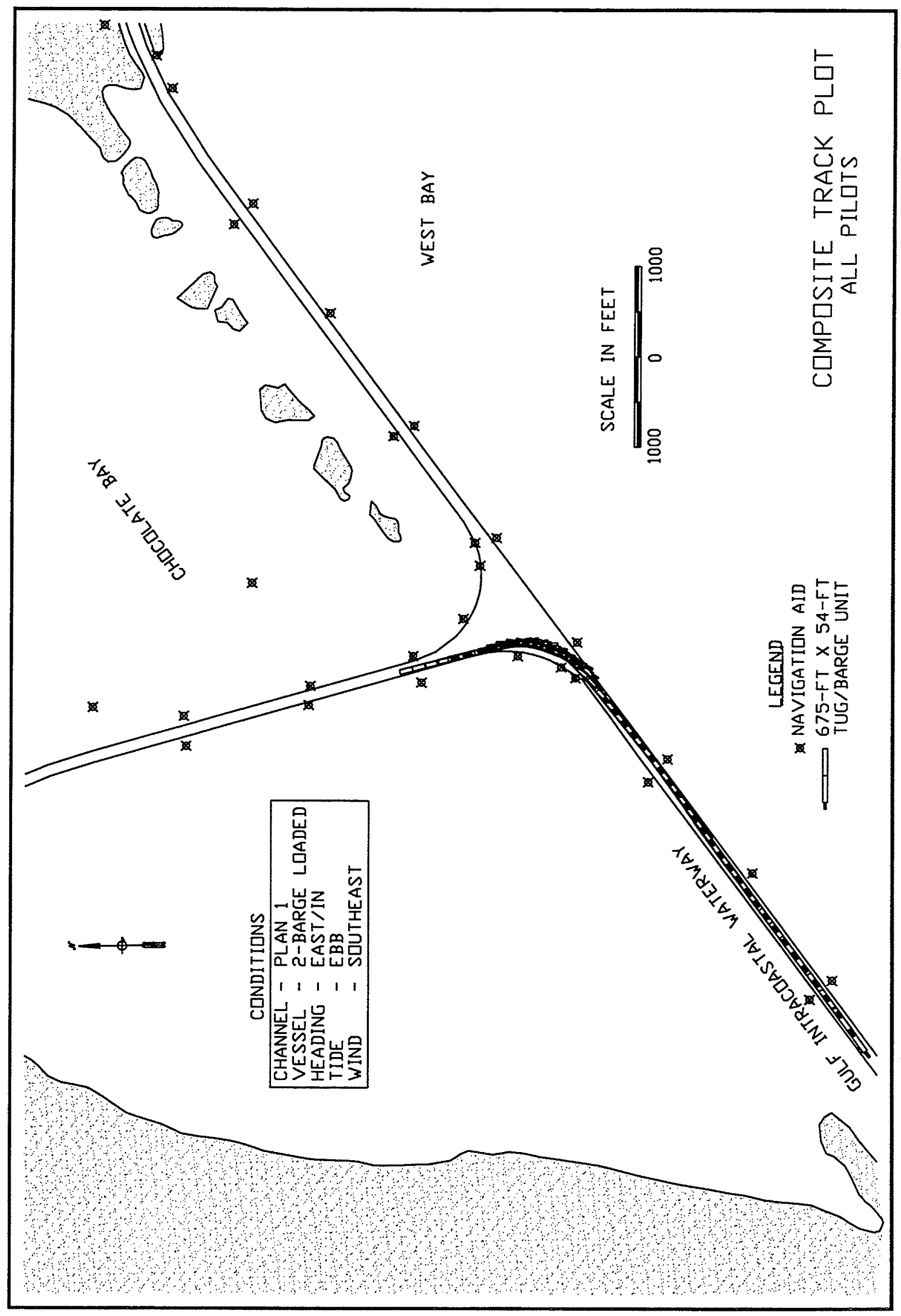

Plate 38 


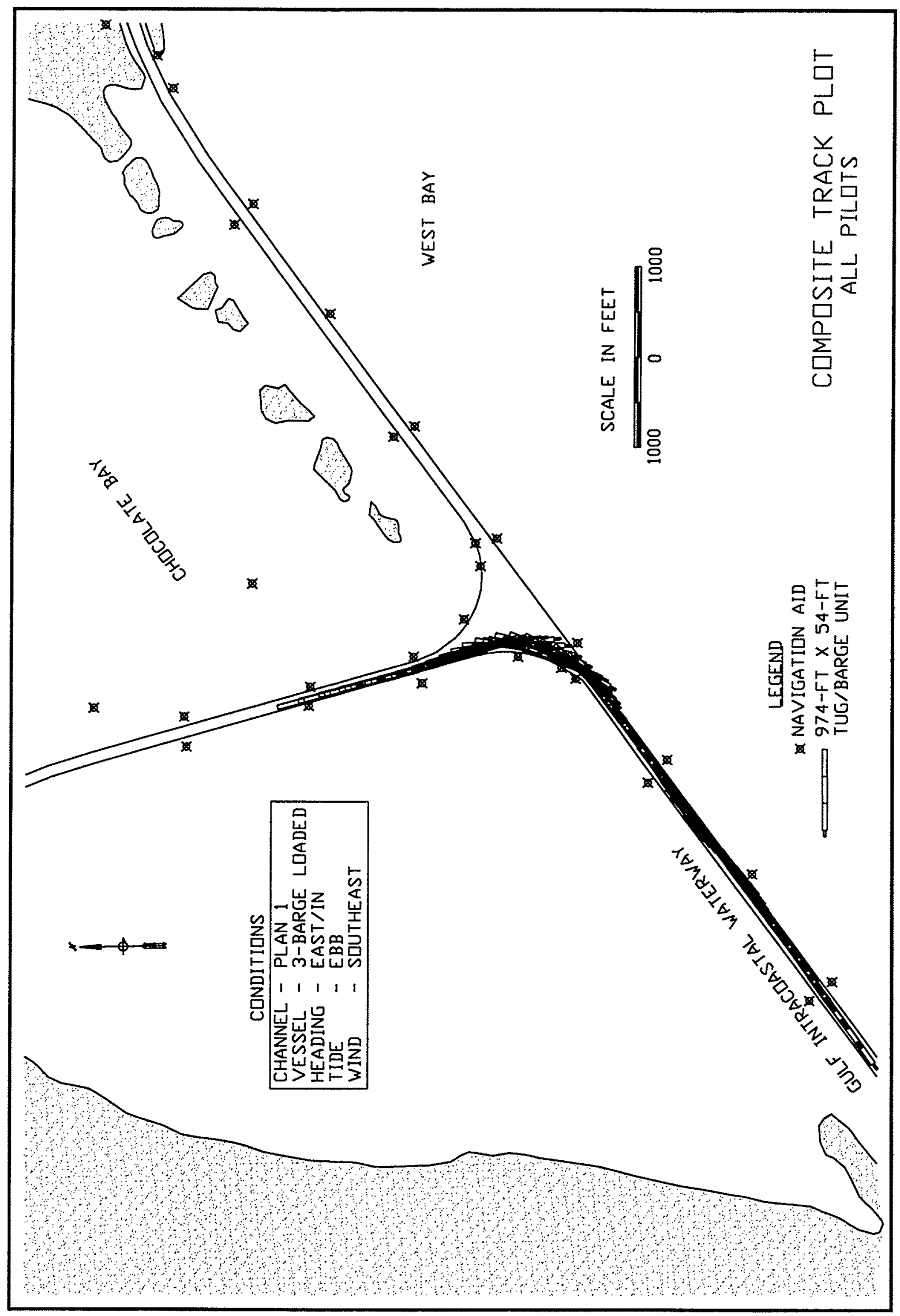

Plate 39 


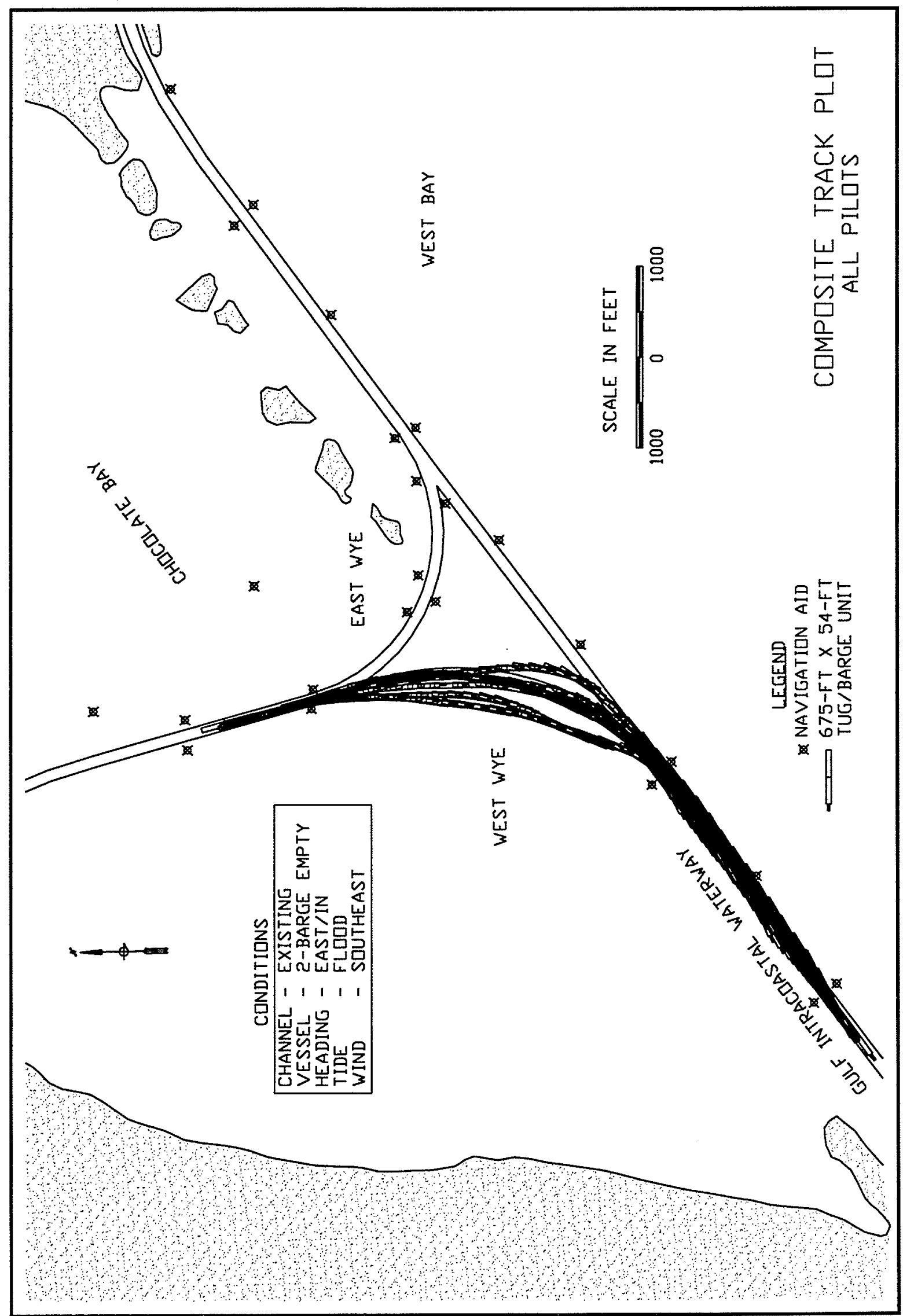

Plate 40 


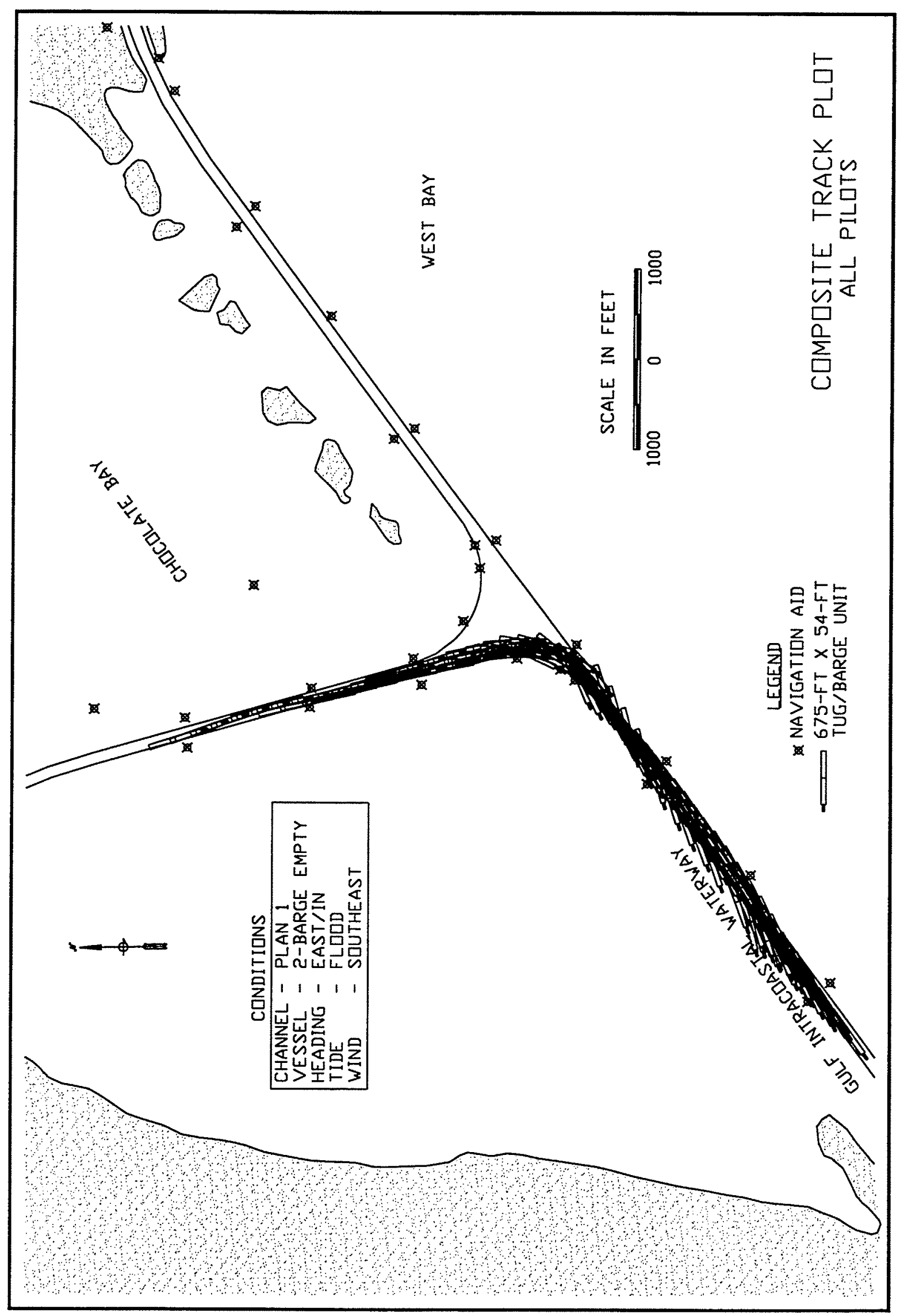

Plate 41 


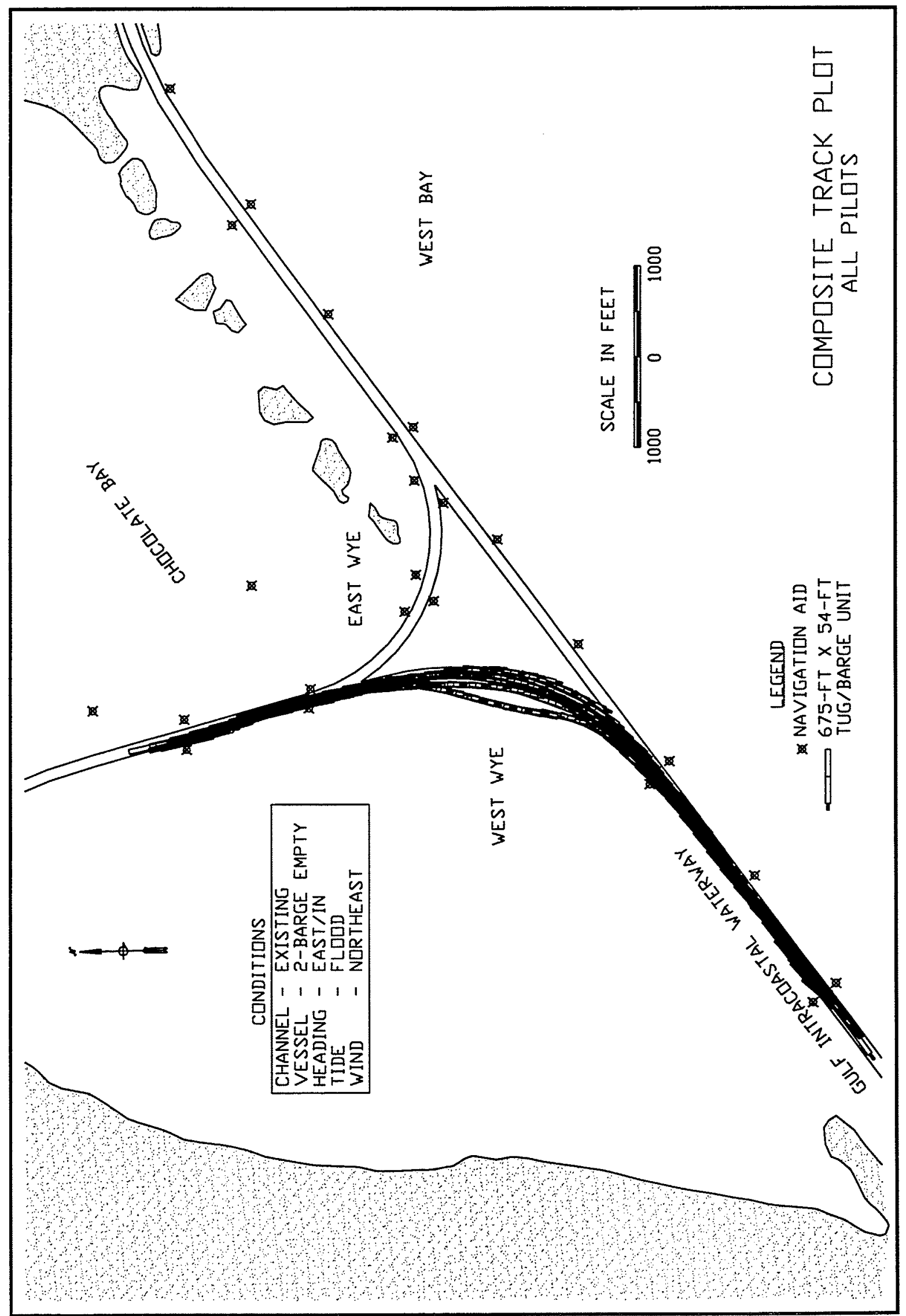

Plate 42 


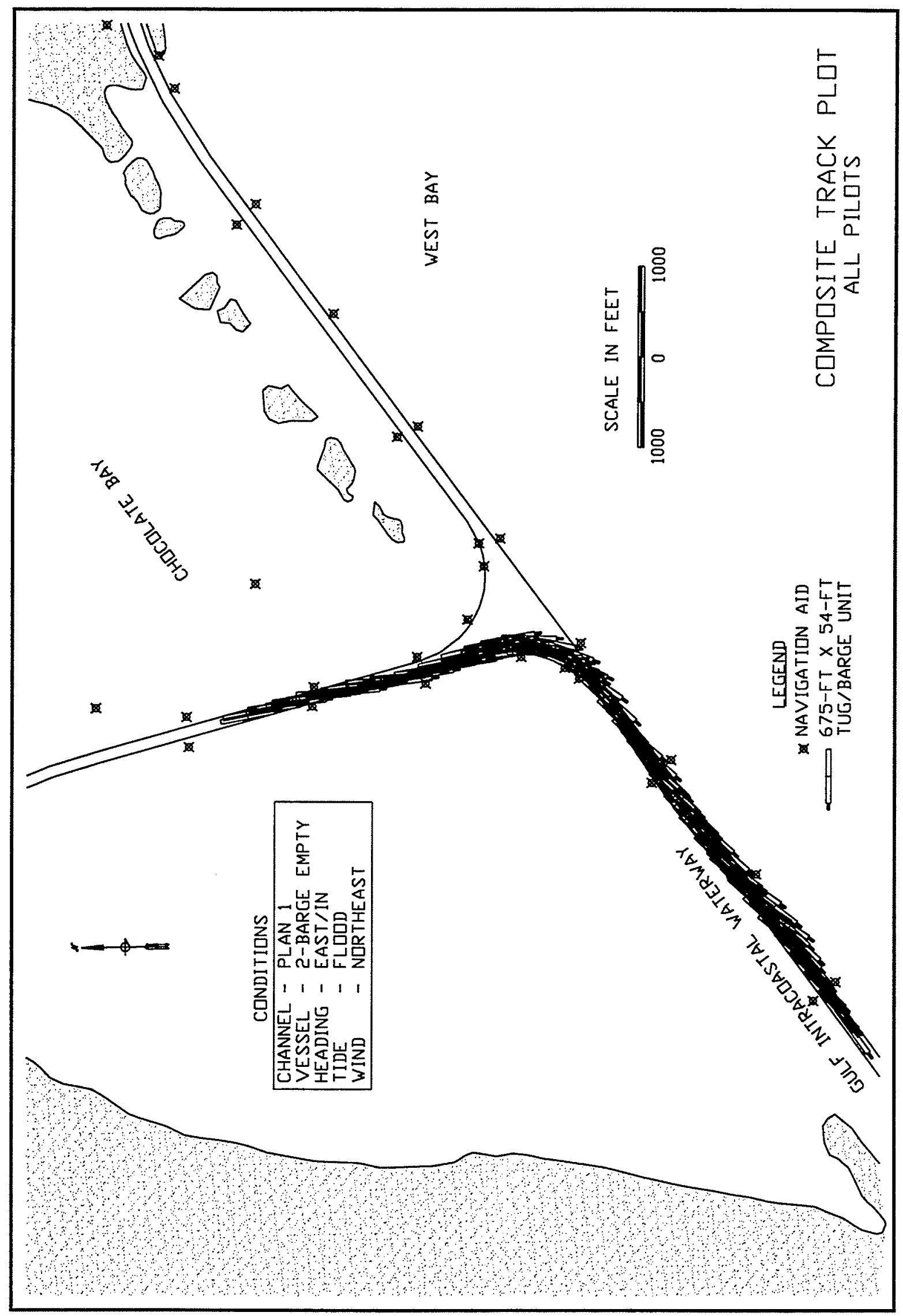

Plate 43 


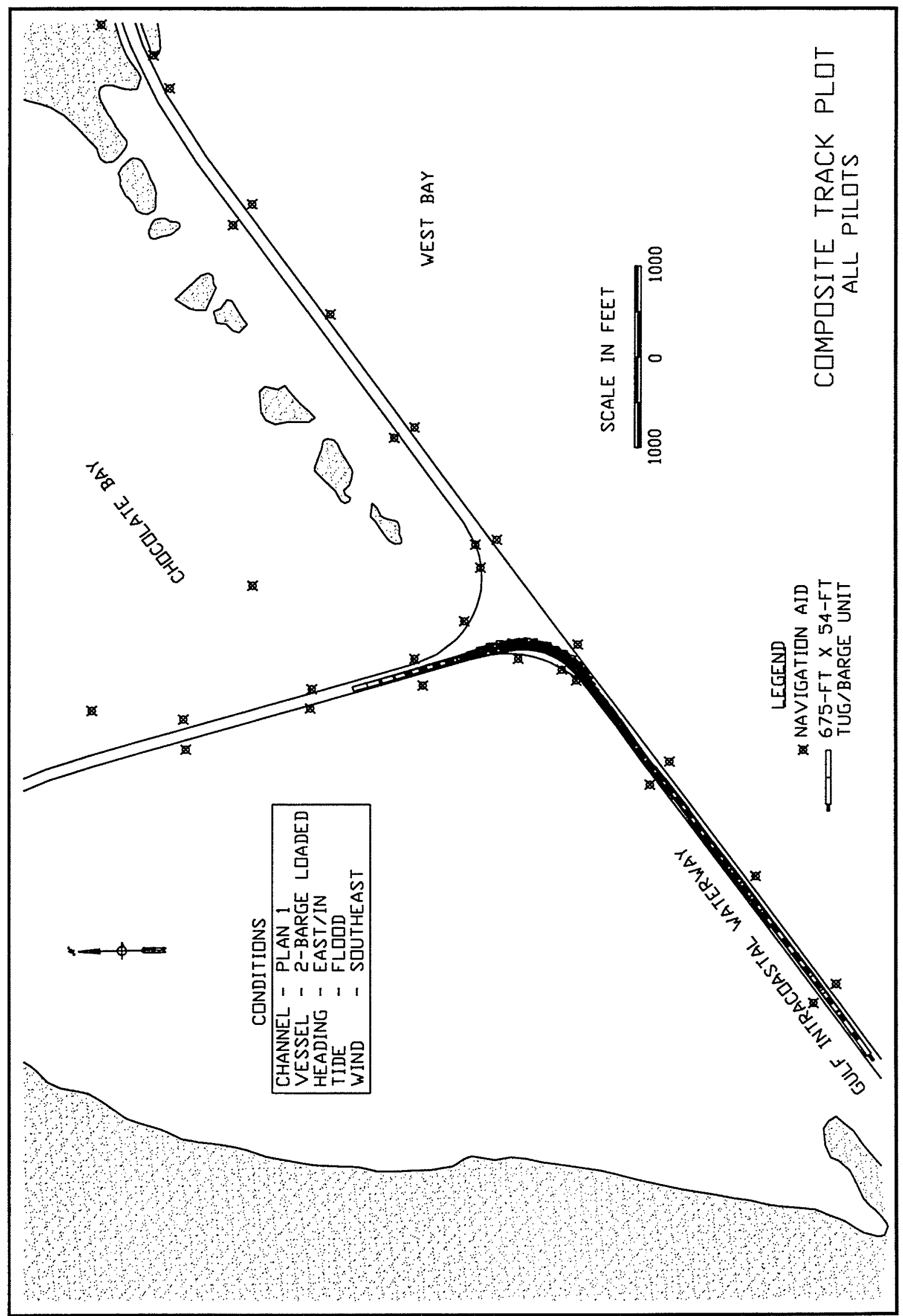

Plate 44 


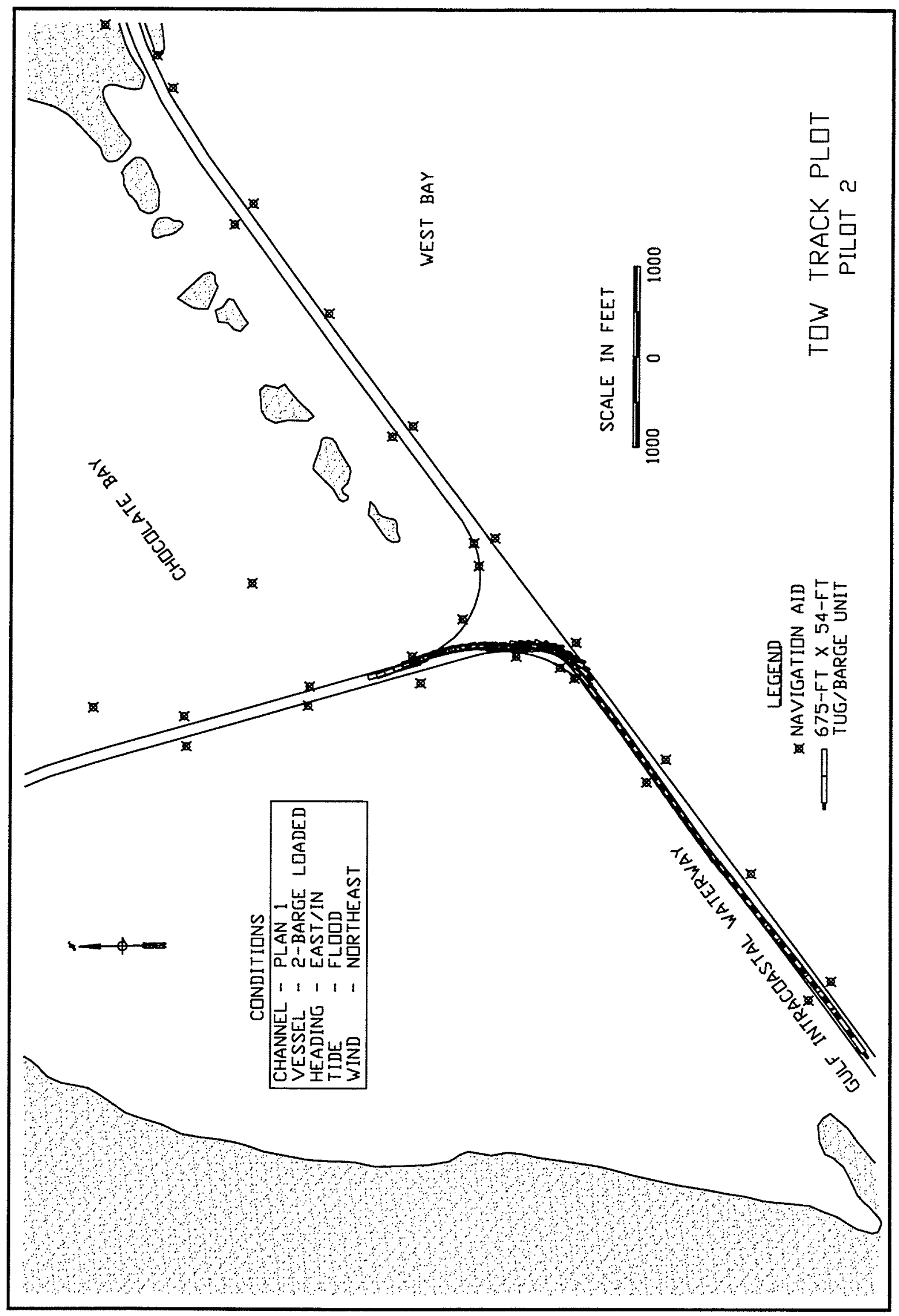

Plate 45 


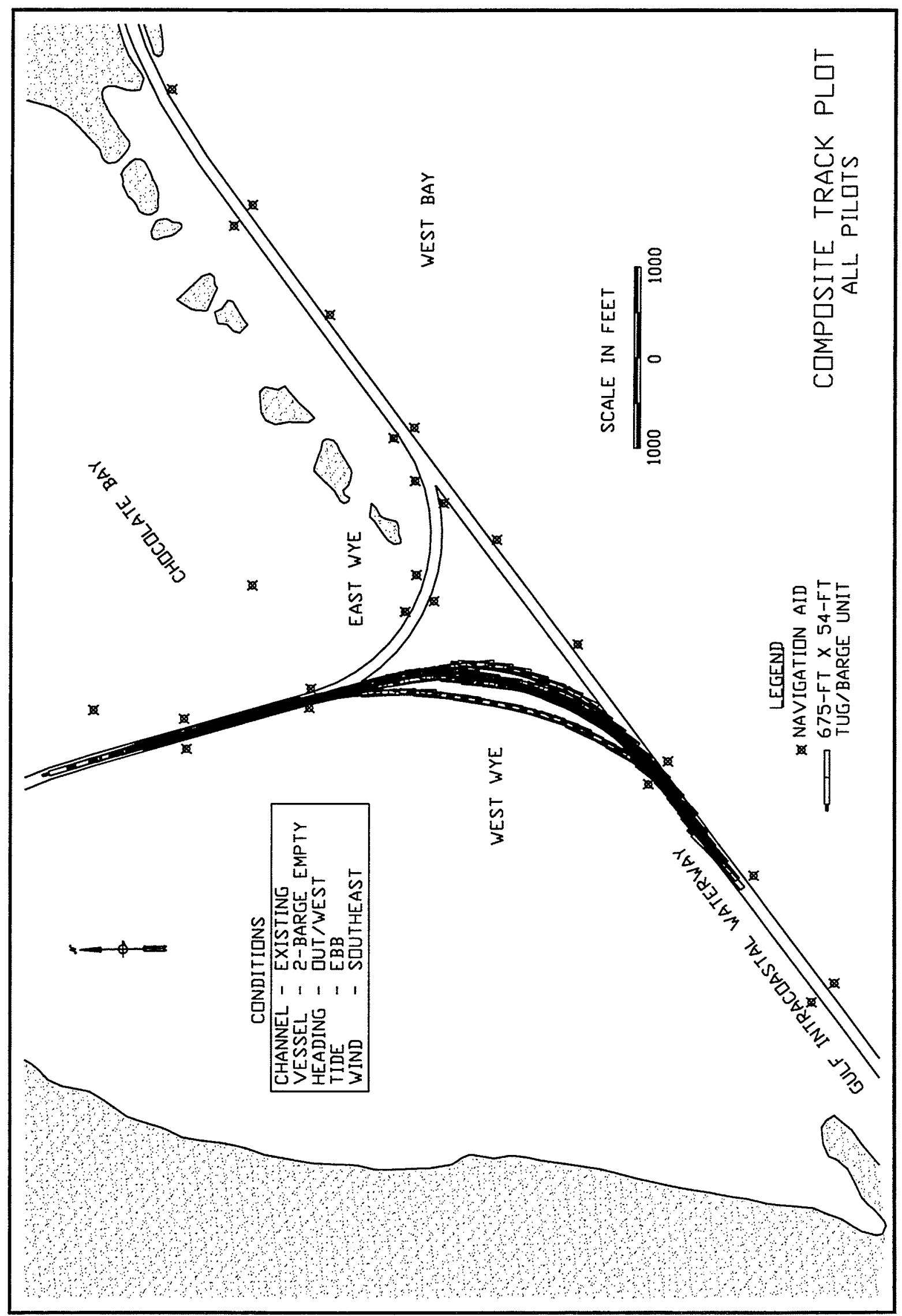

Plate 46 


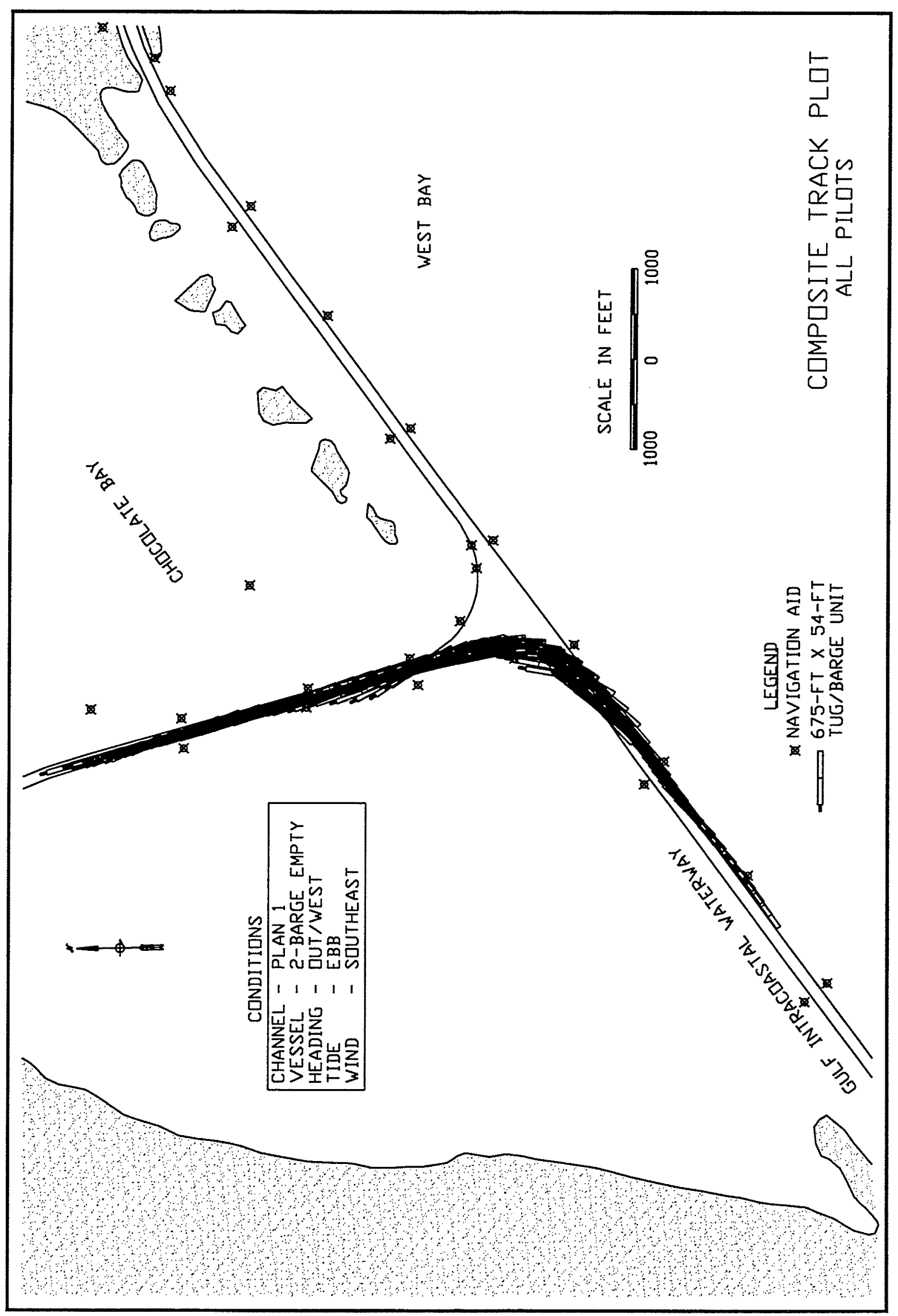

Plate 47 


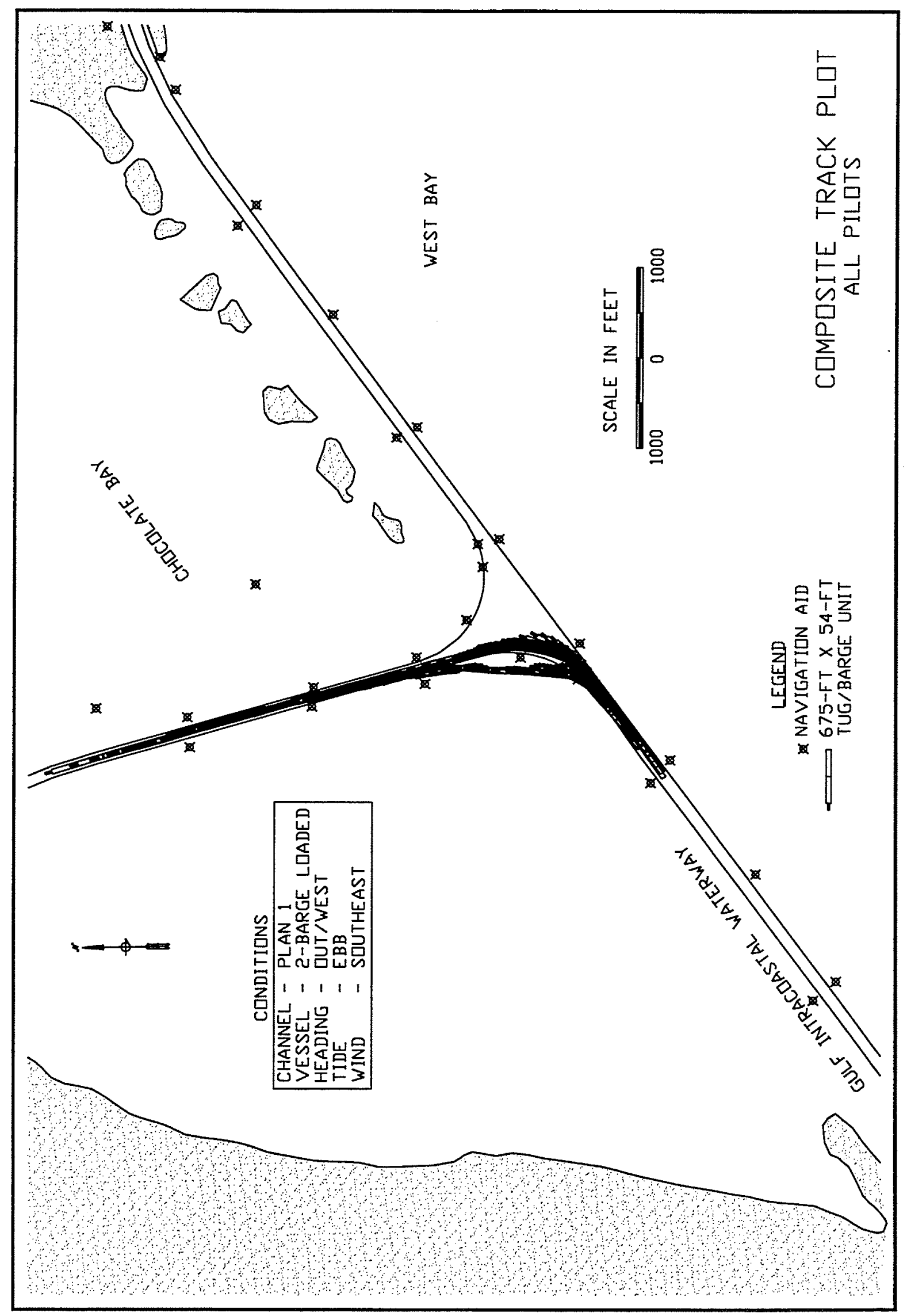

Plate 48 


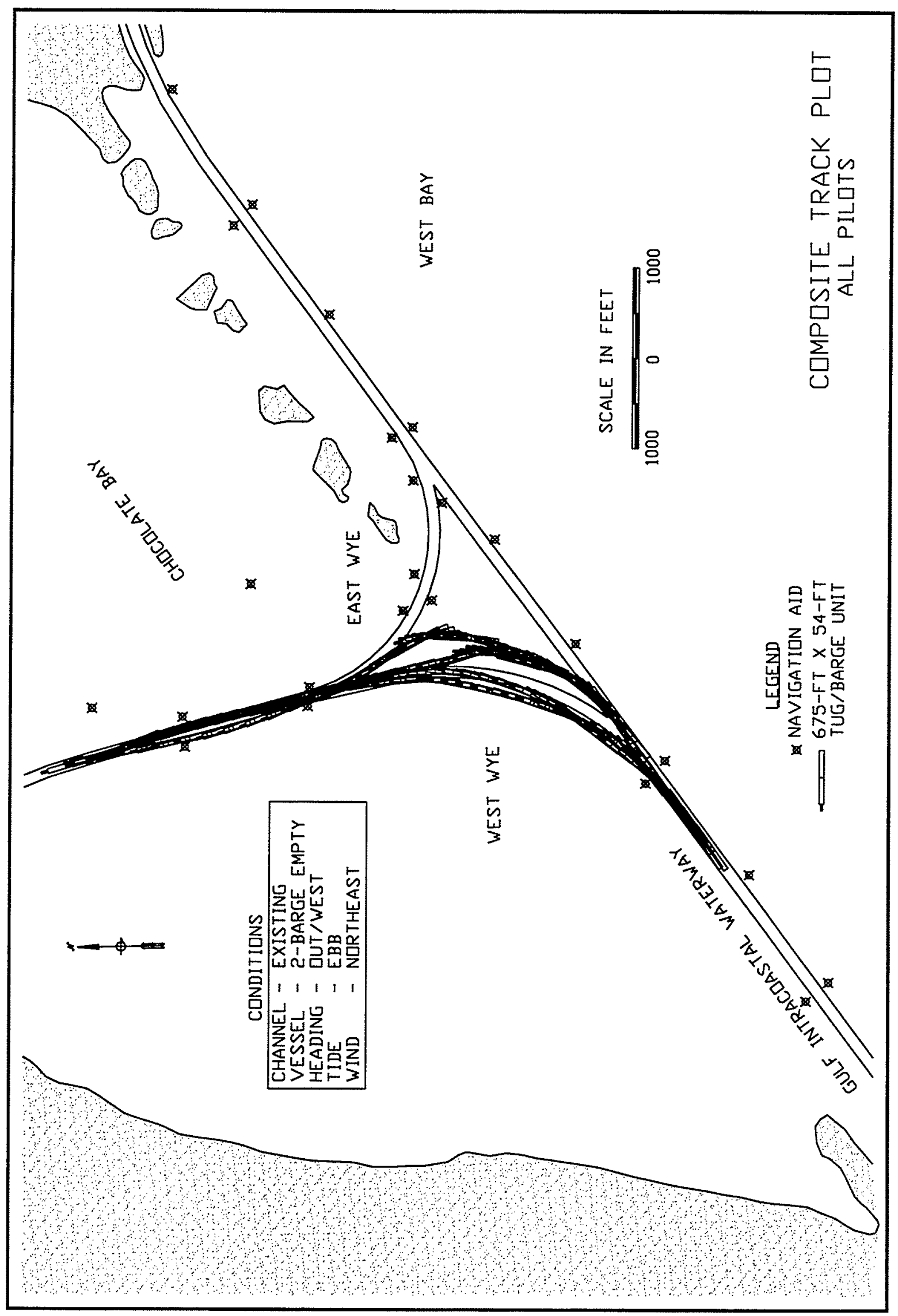

Plate 49 


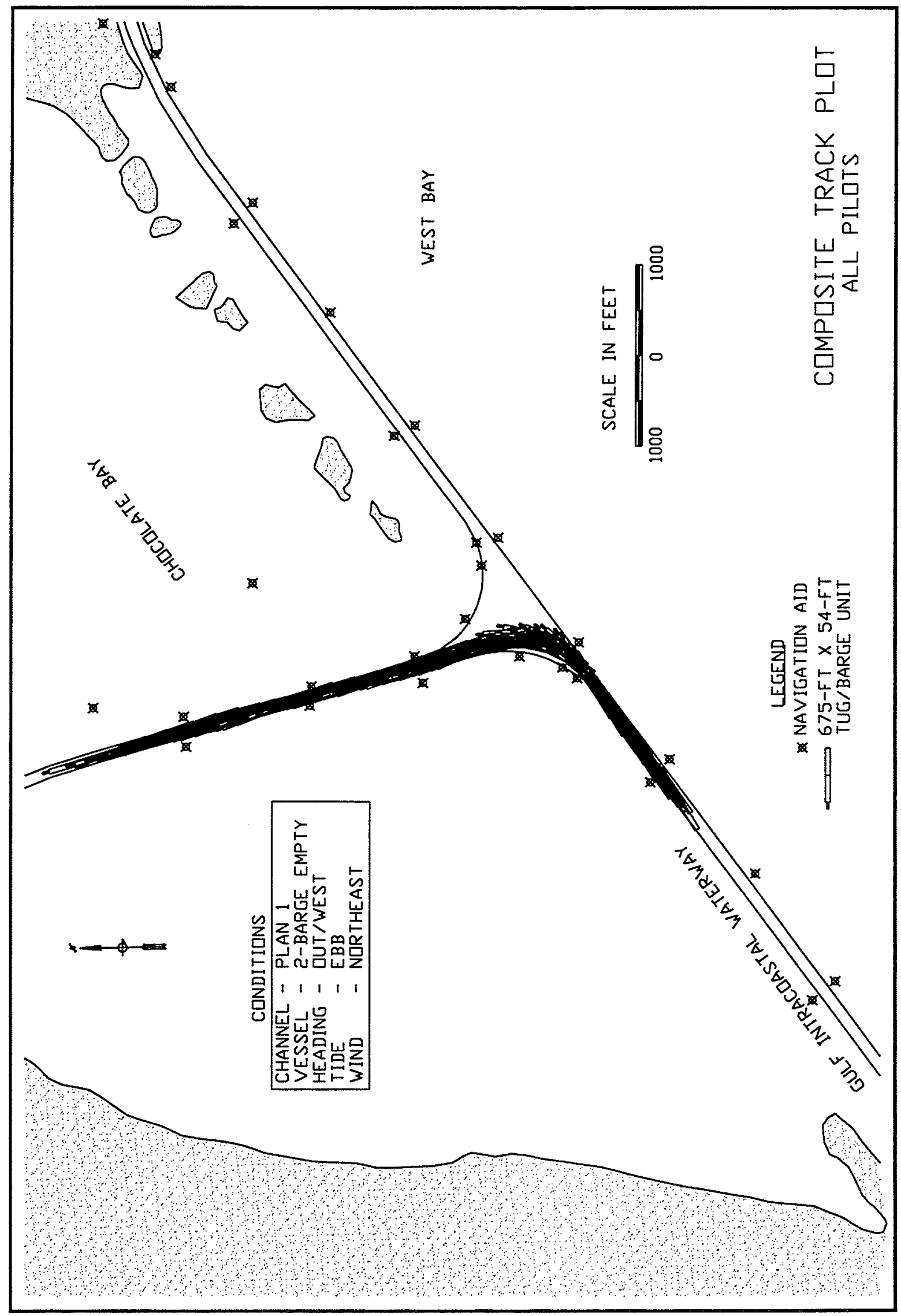

Plate 50 


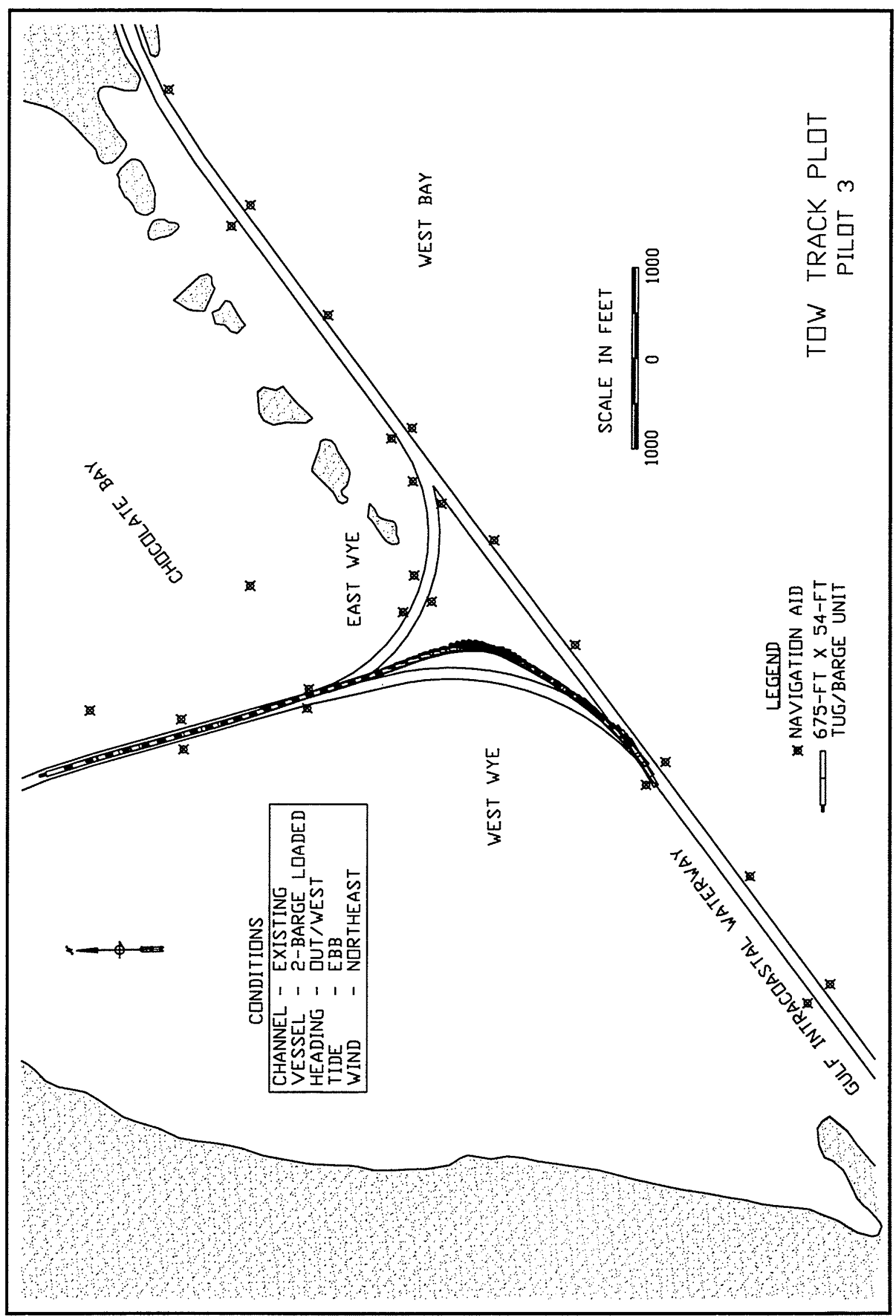

Plate 51 


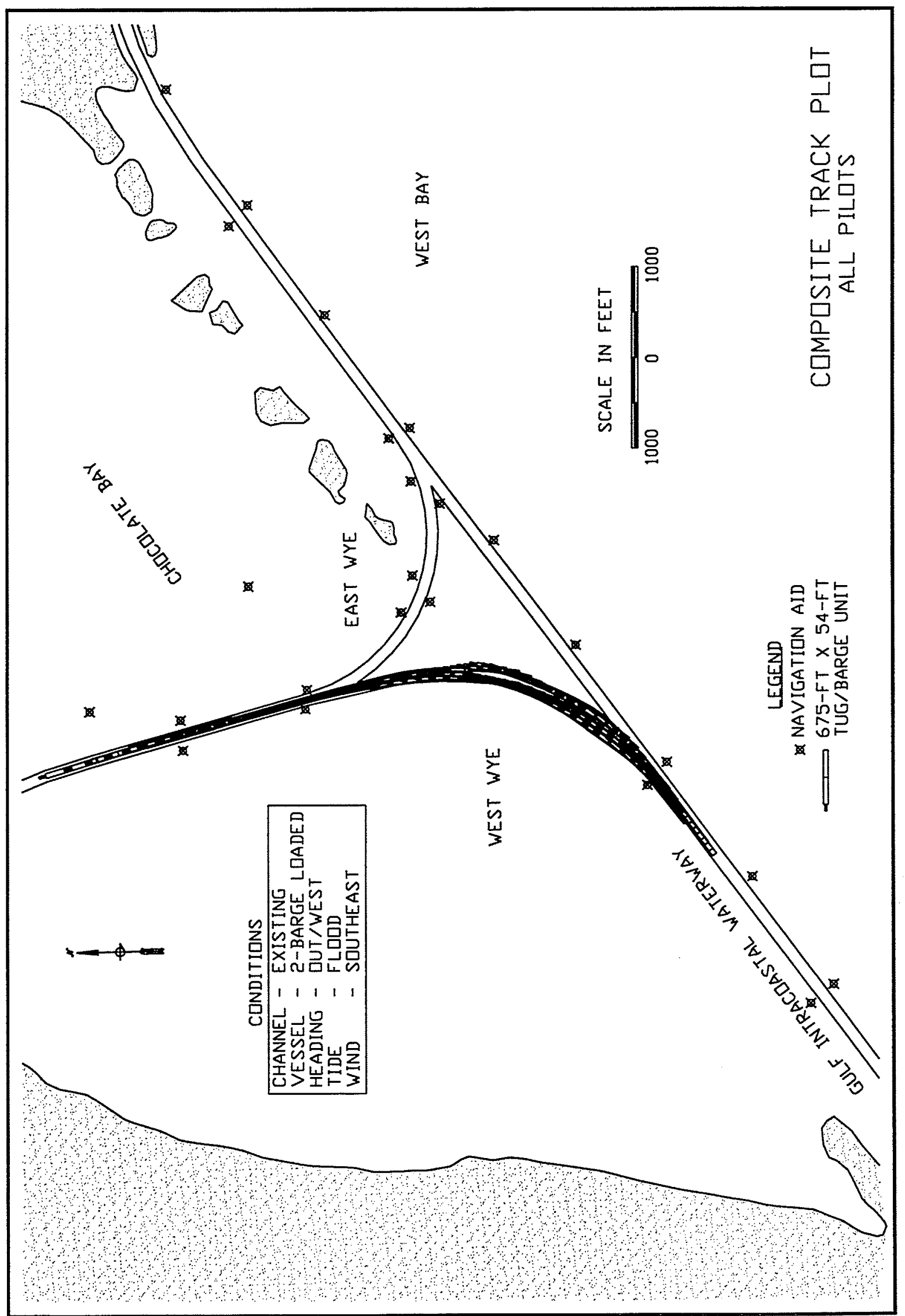

Plate 52 


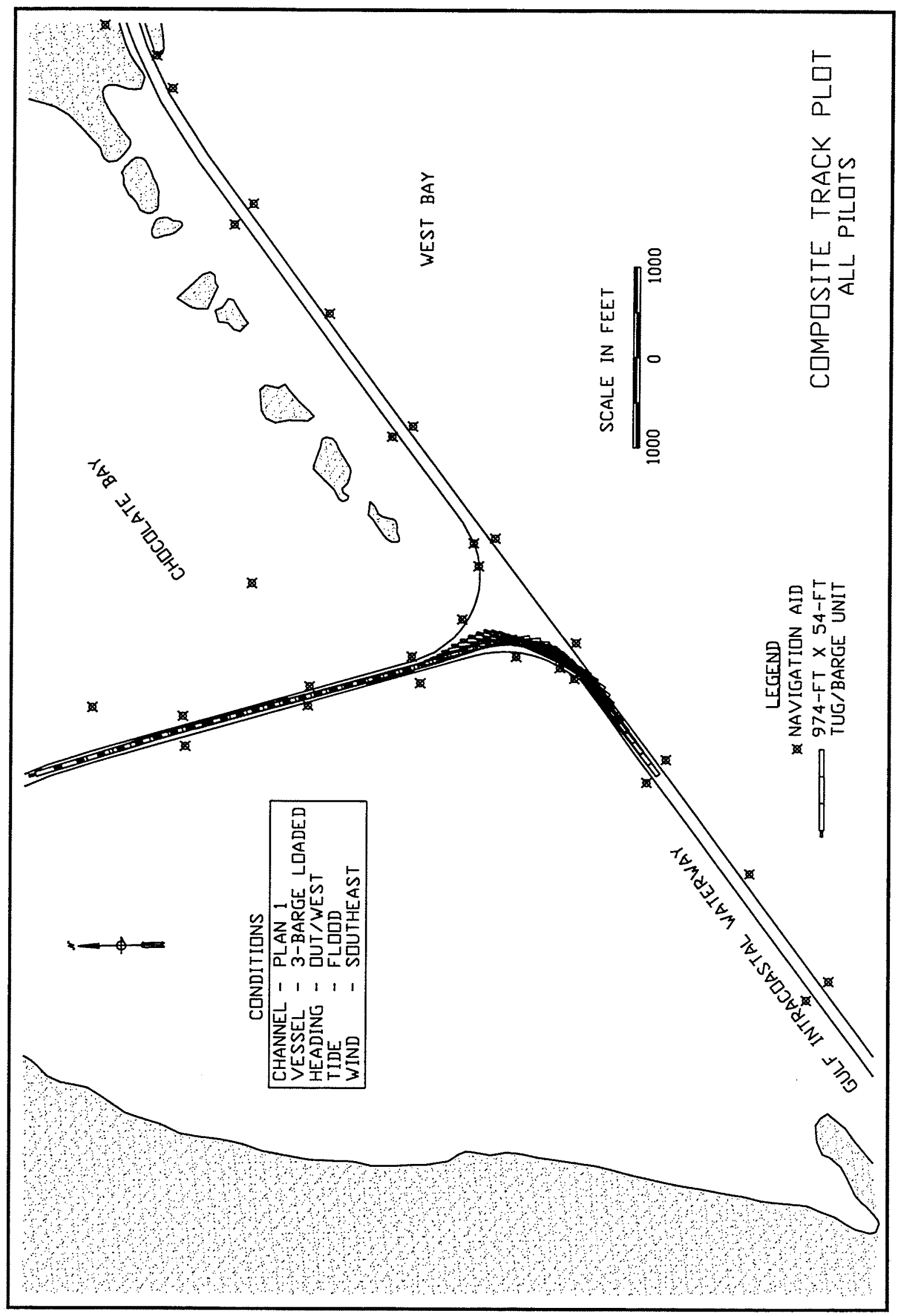

Plate 53 


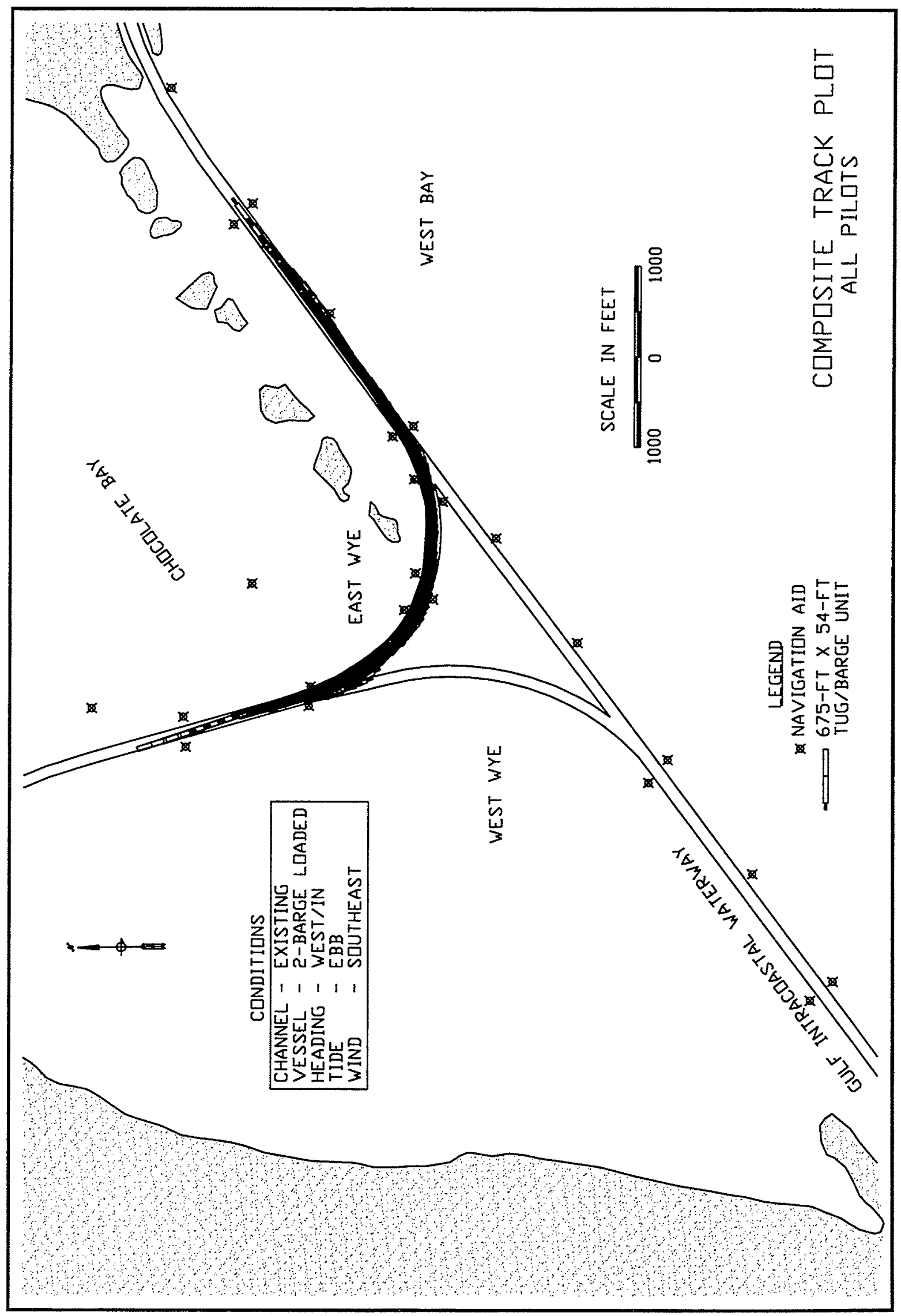

Plate 54 


$$
D_{H}
$$




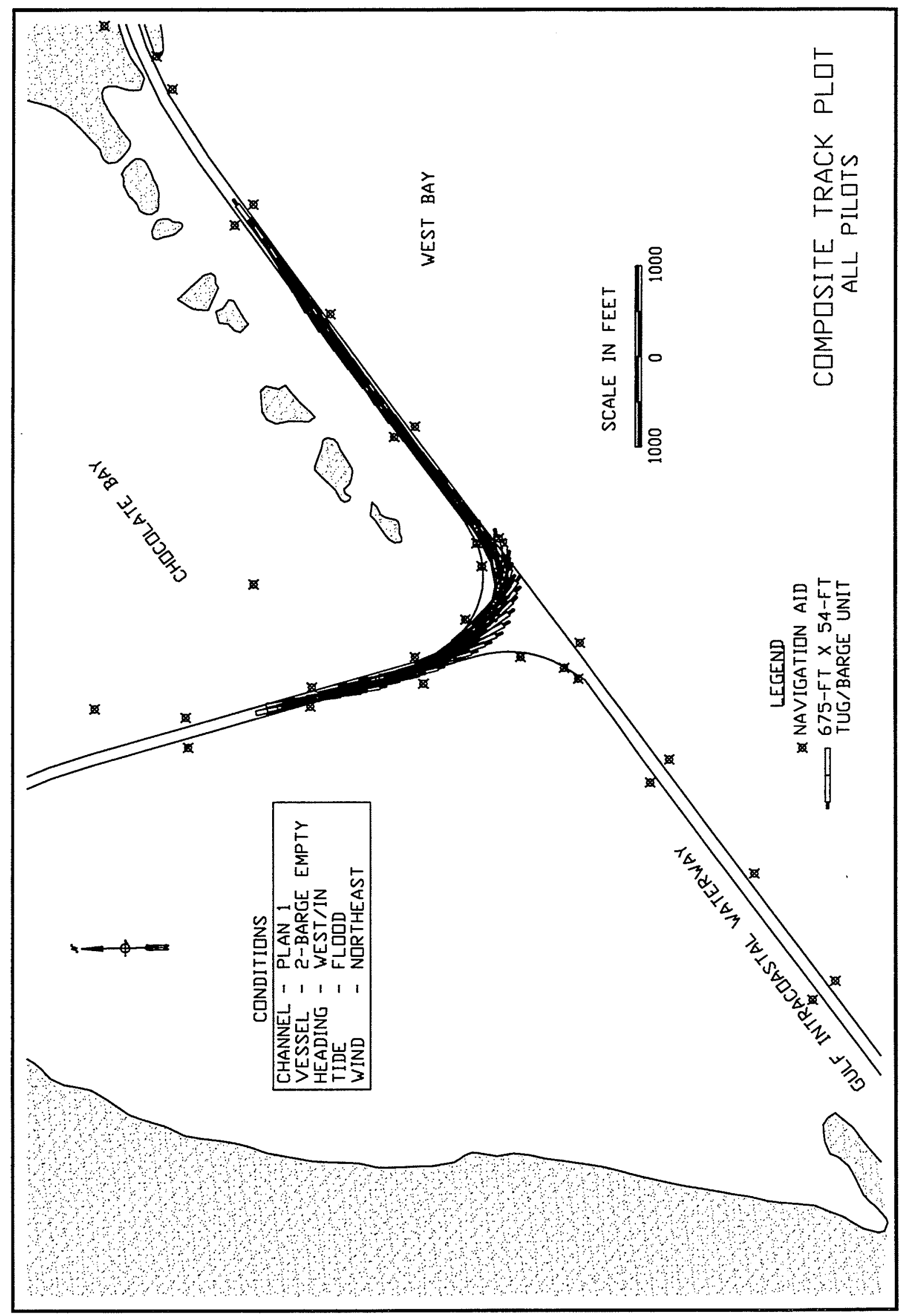

Plate 56 


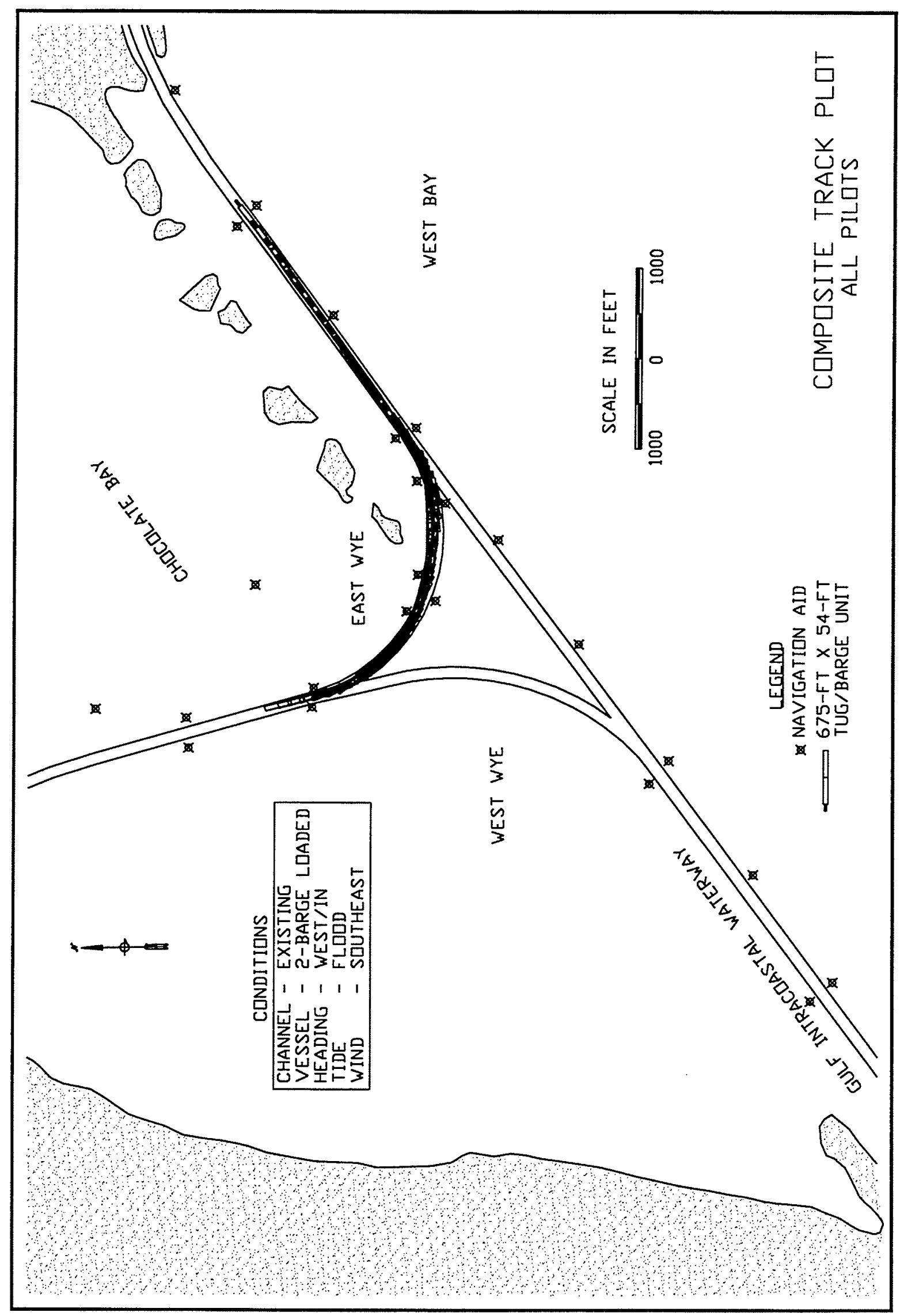

Plate 57 


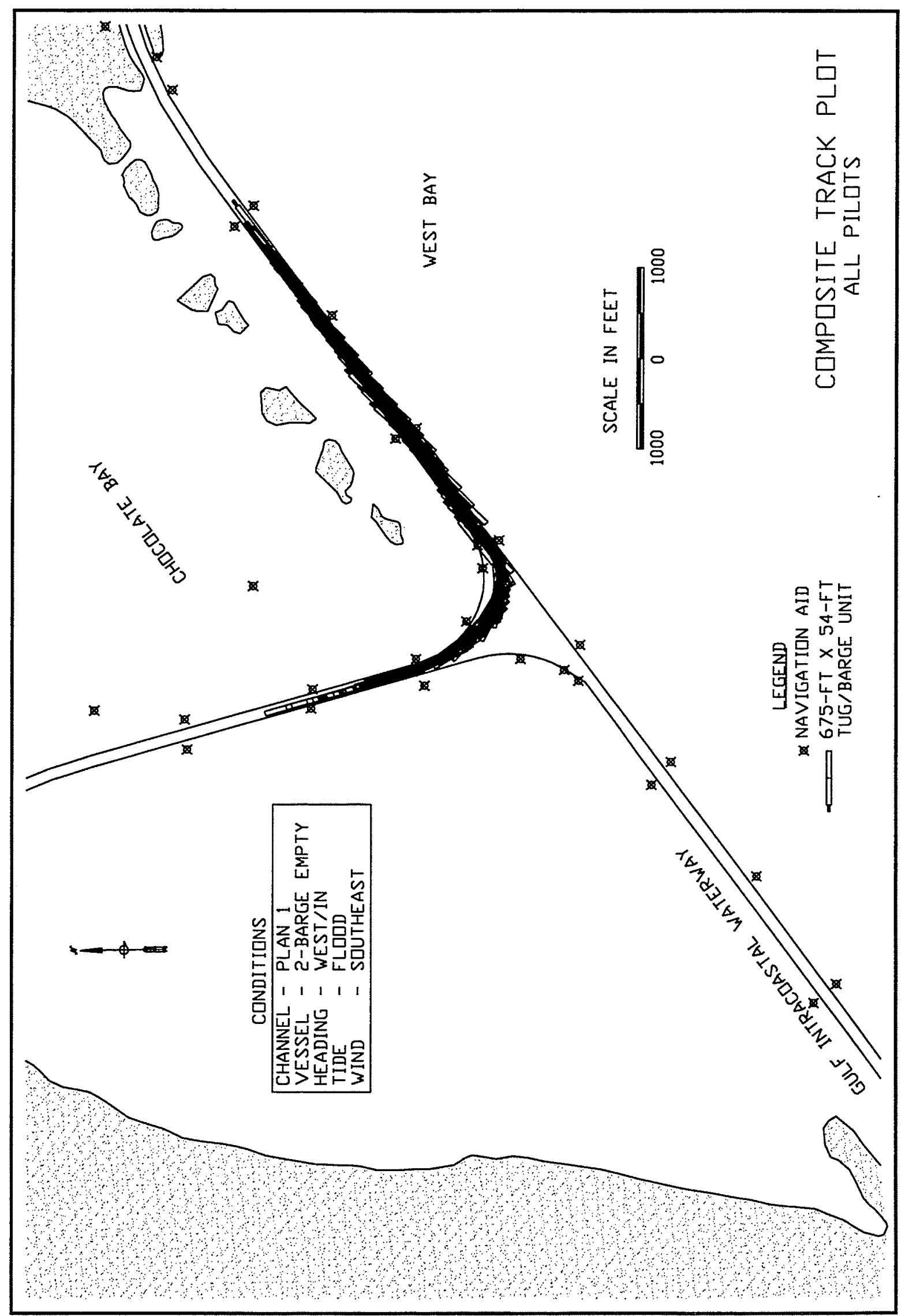

Plate 58 


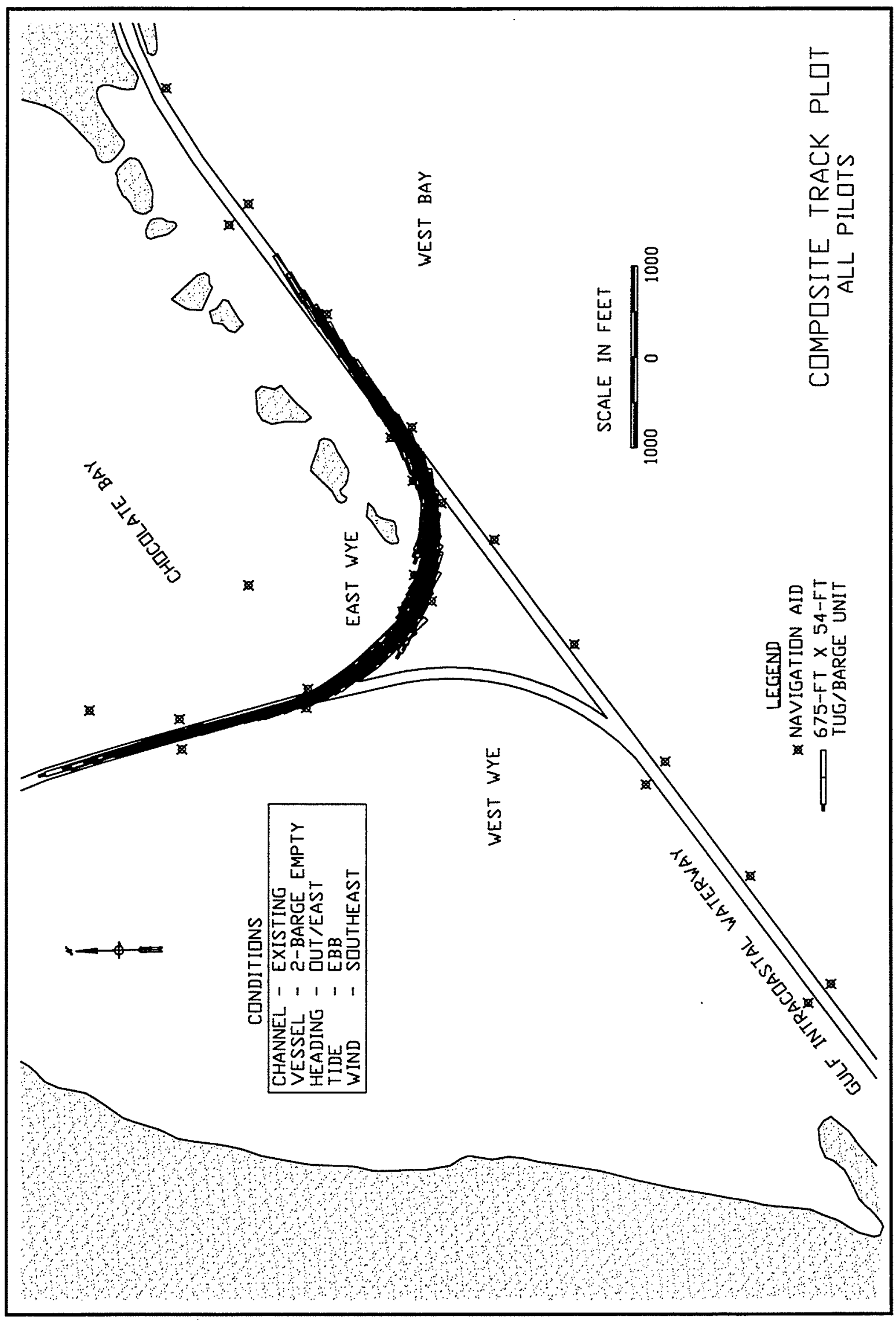

Plate 59 


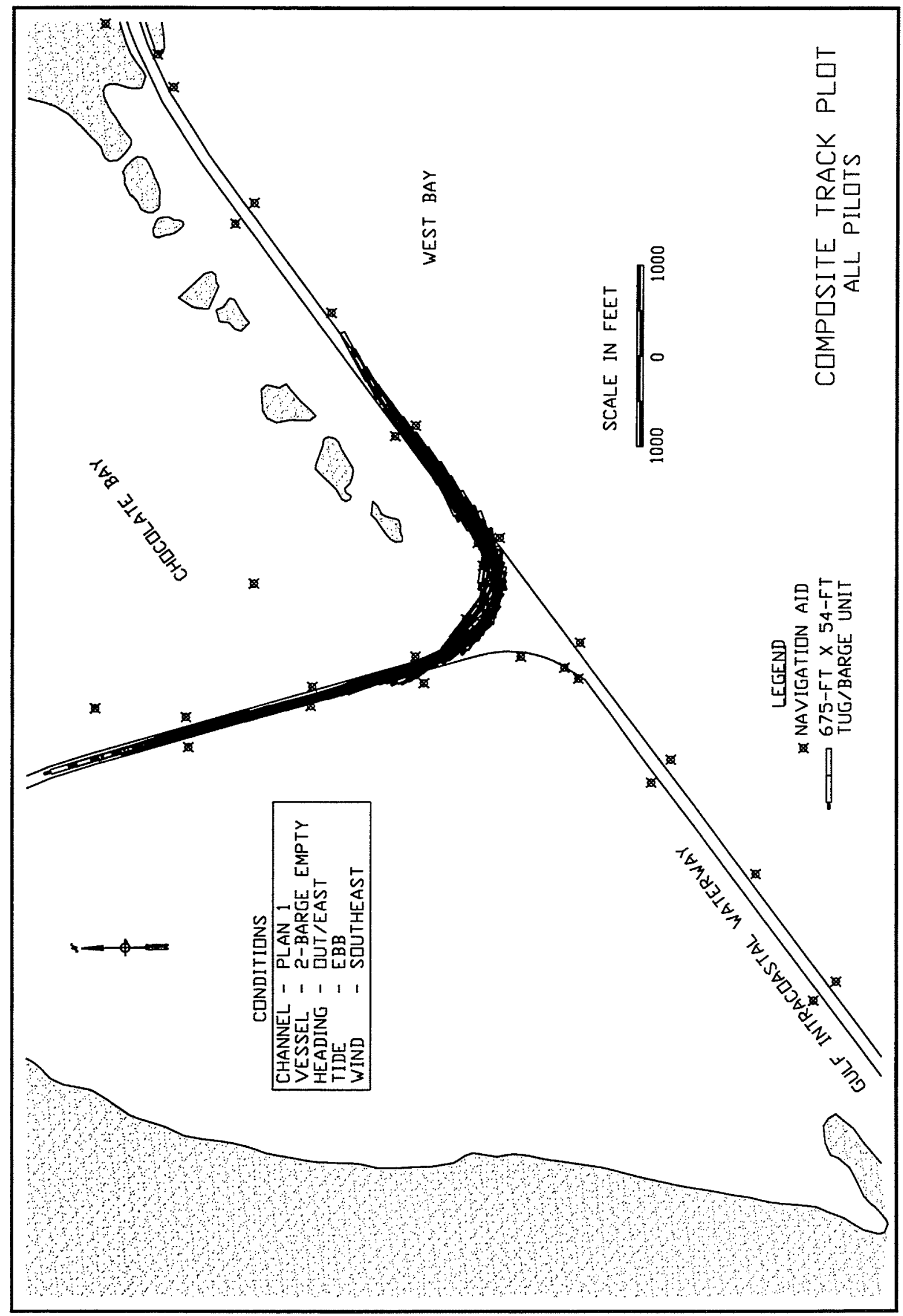

Plate 60 


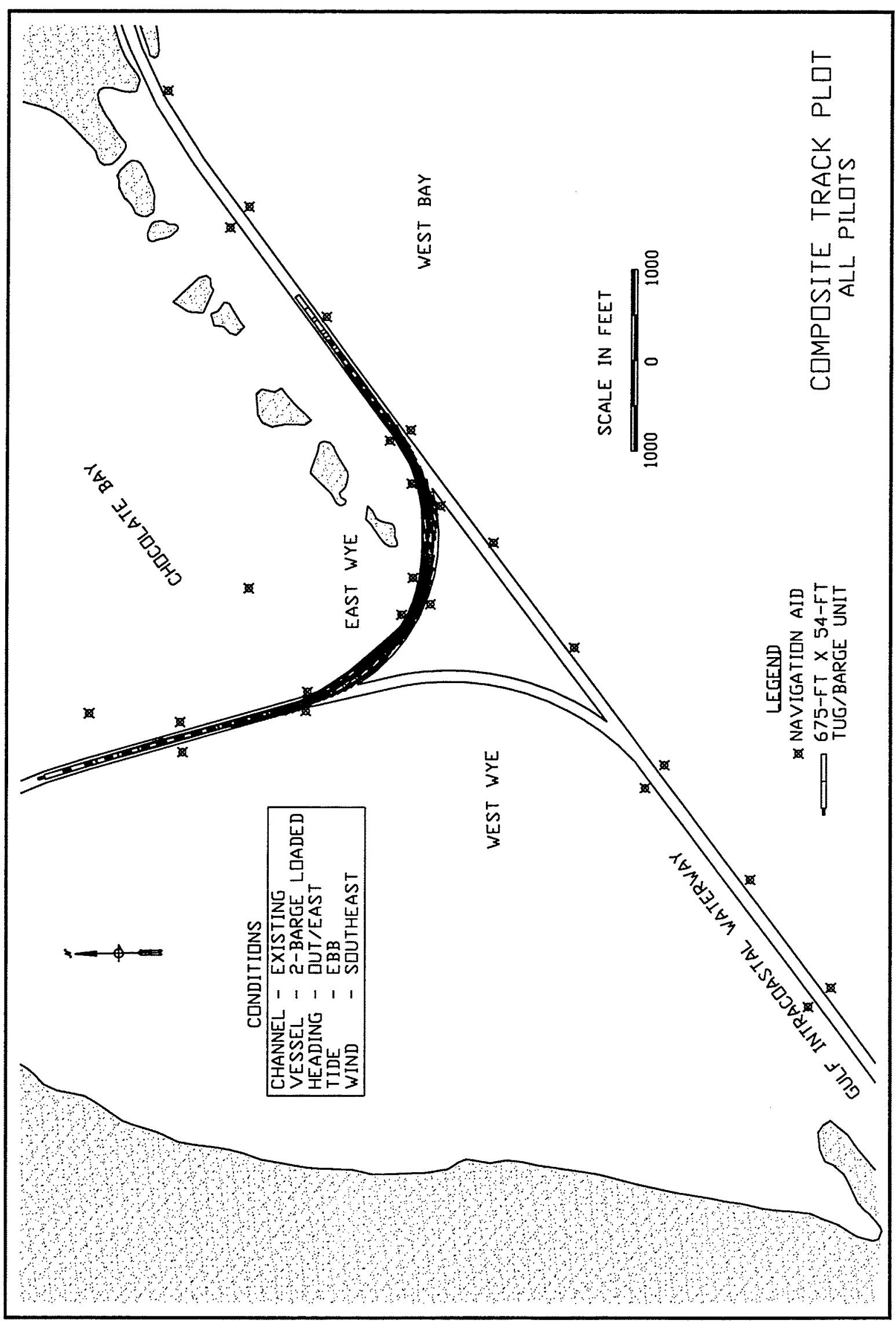

Plate 61 


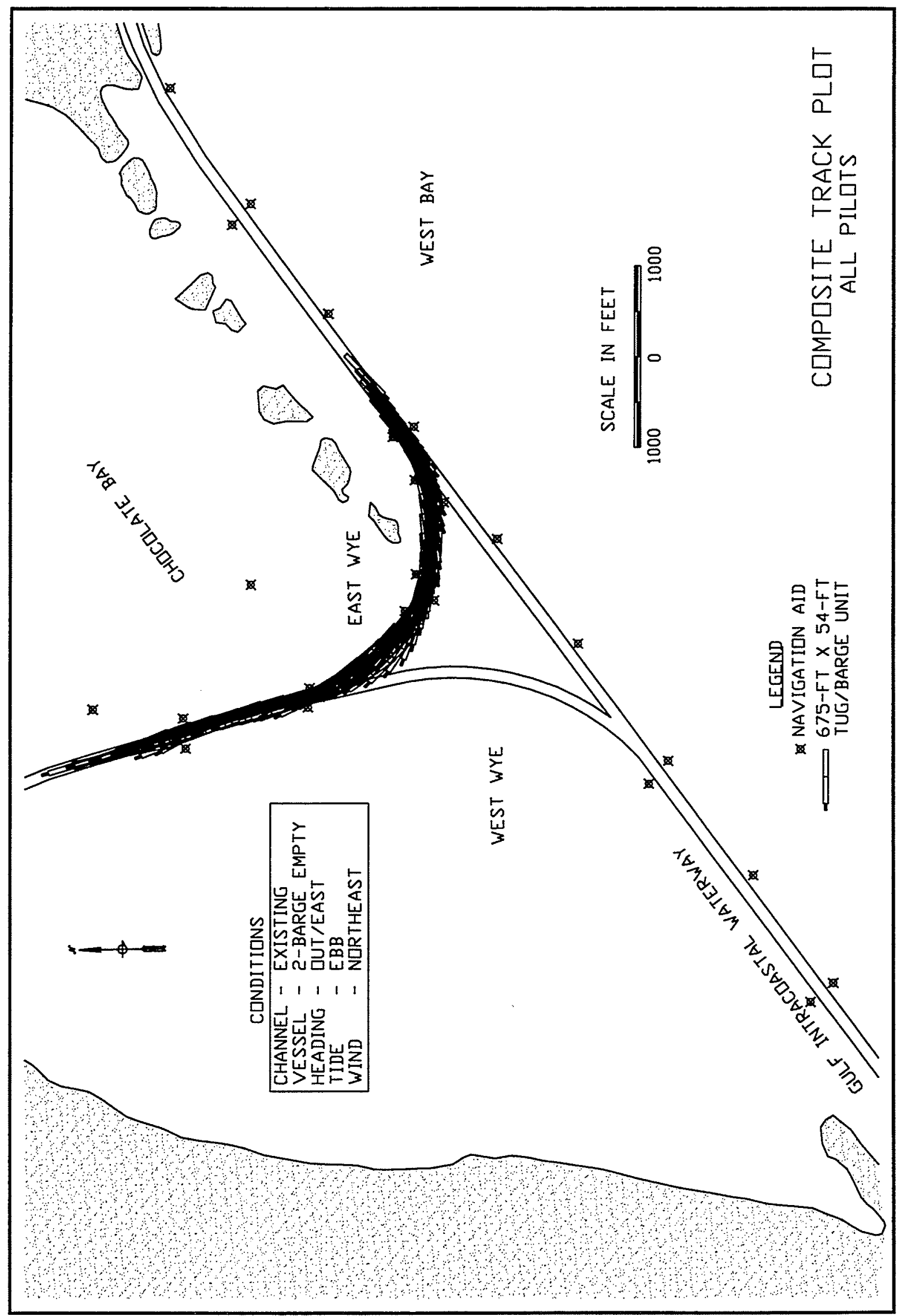

Plate 62 


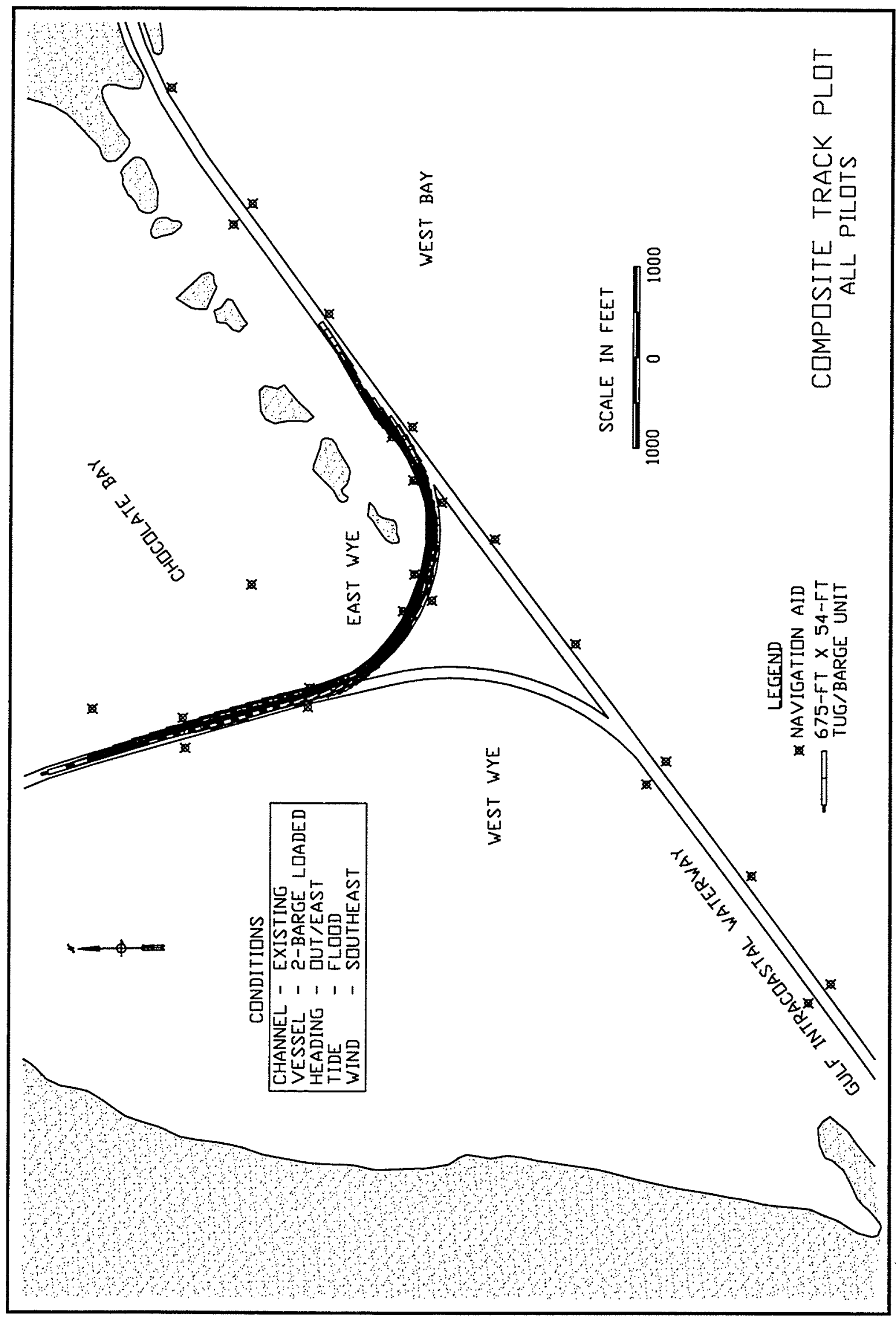

Plate 63 


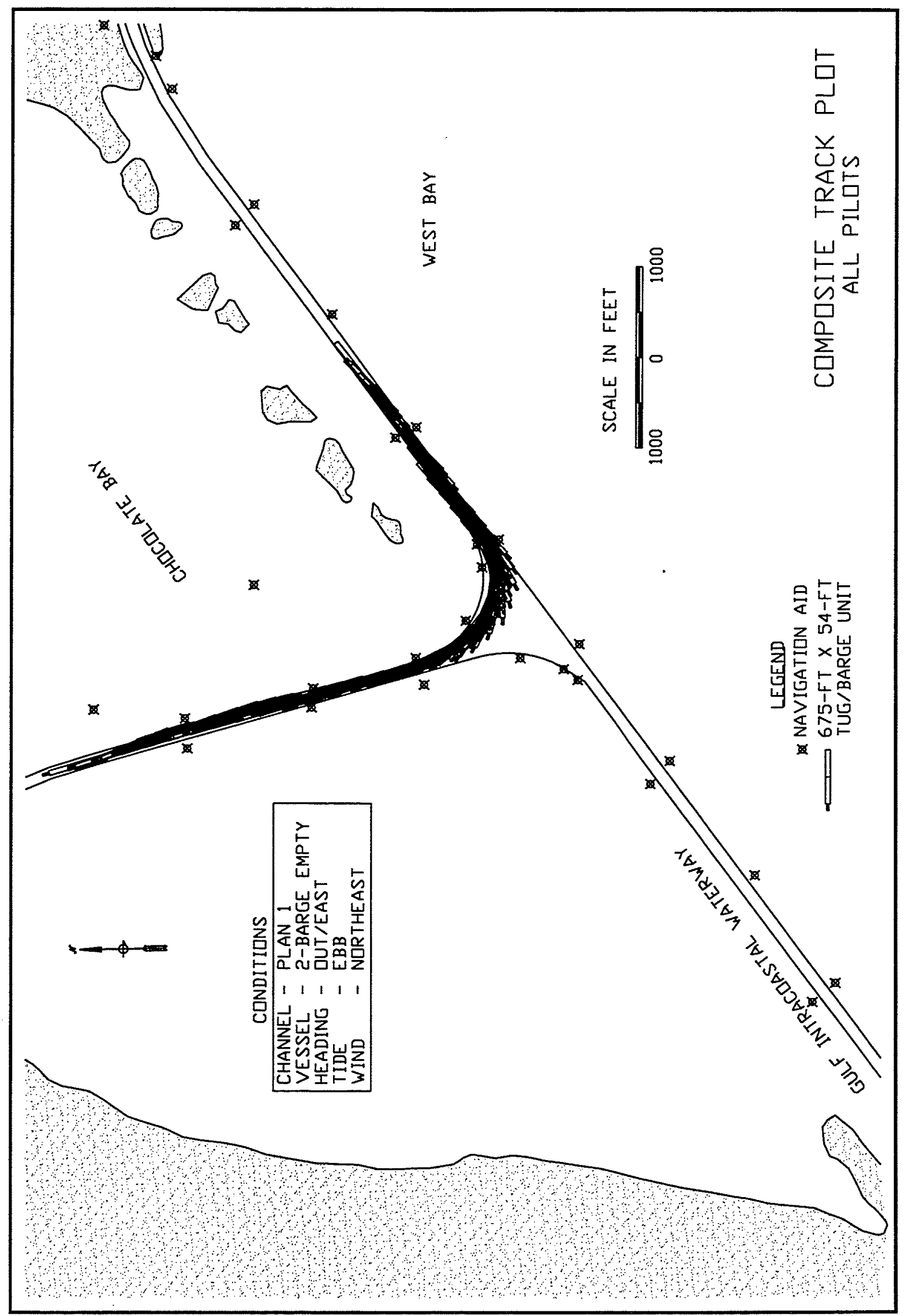

Plate 64 


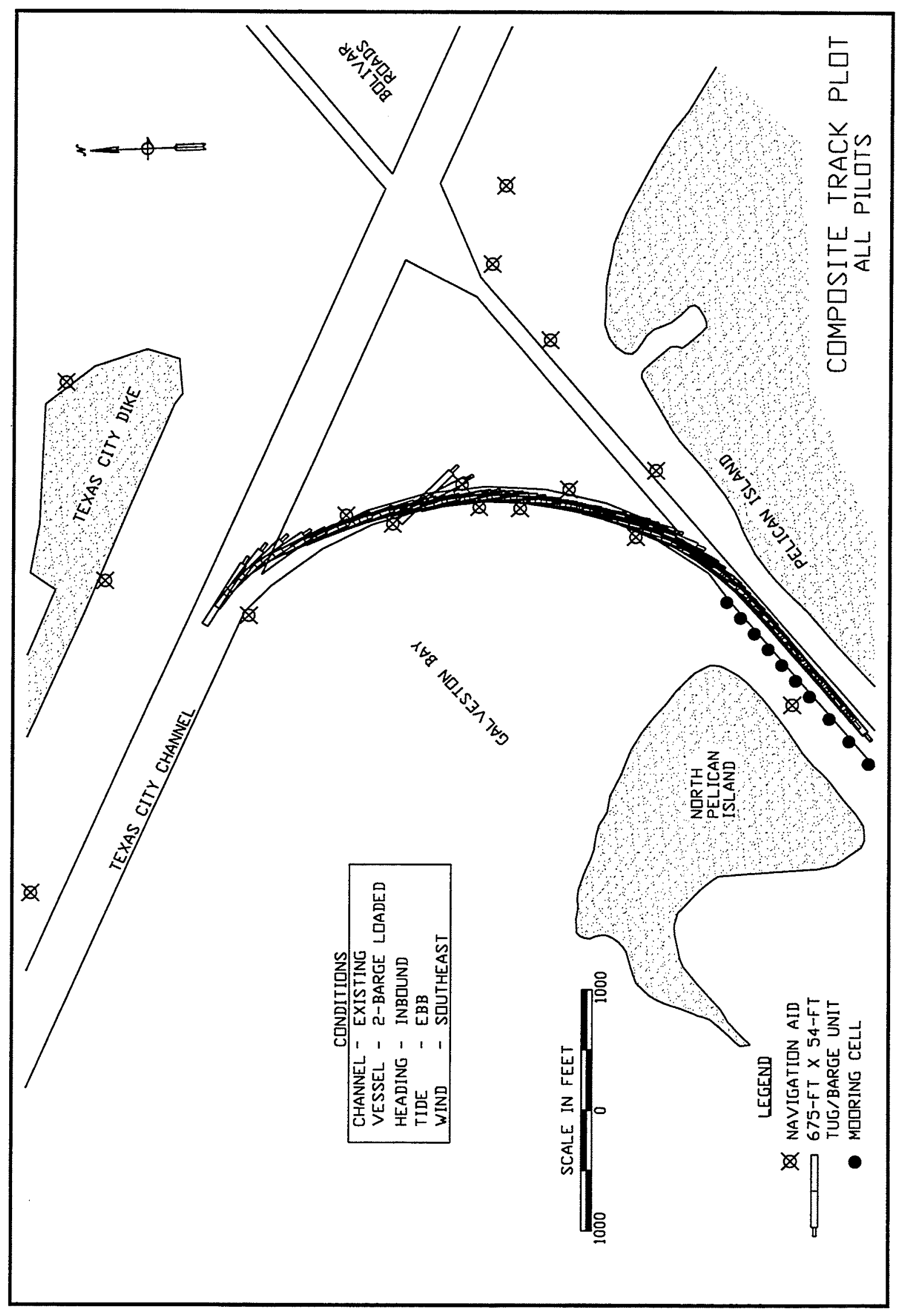

PLATE 65 


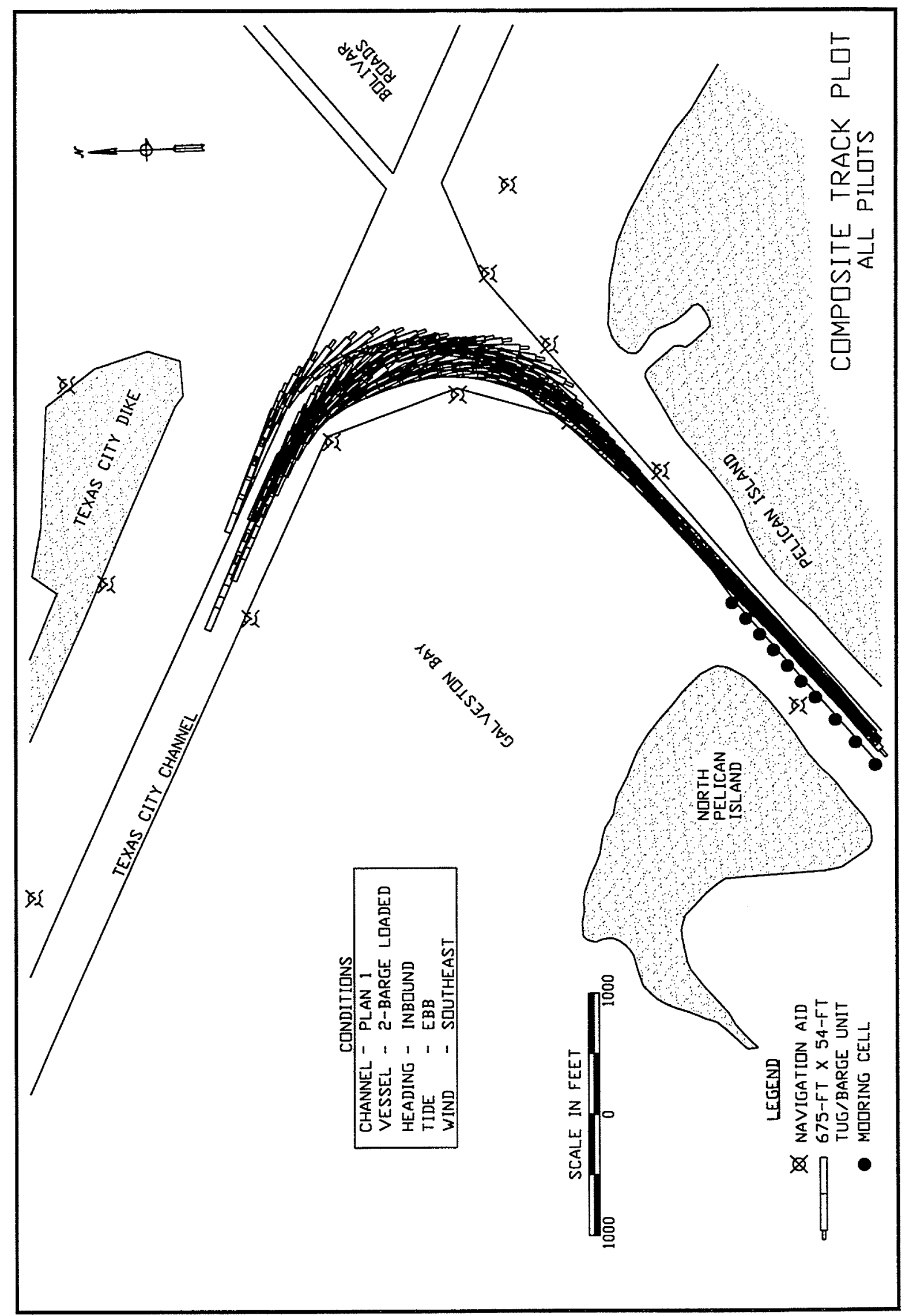

PLATE 66 


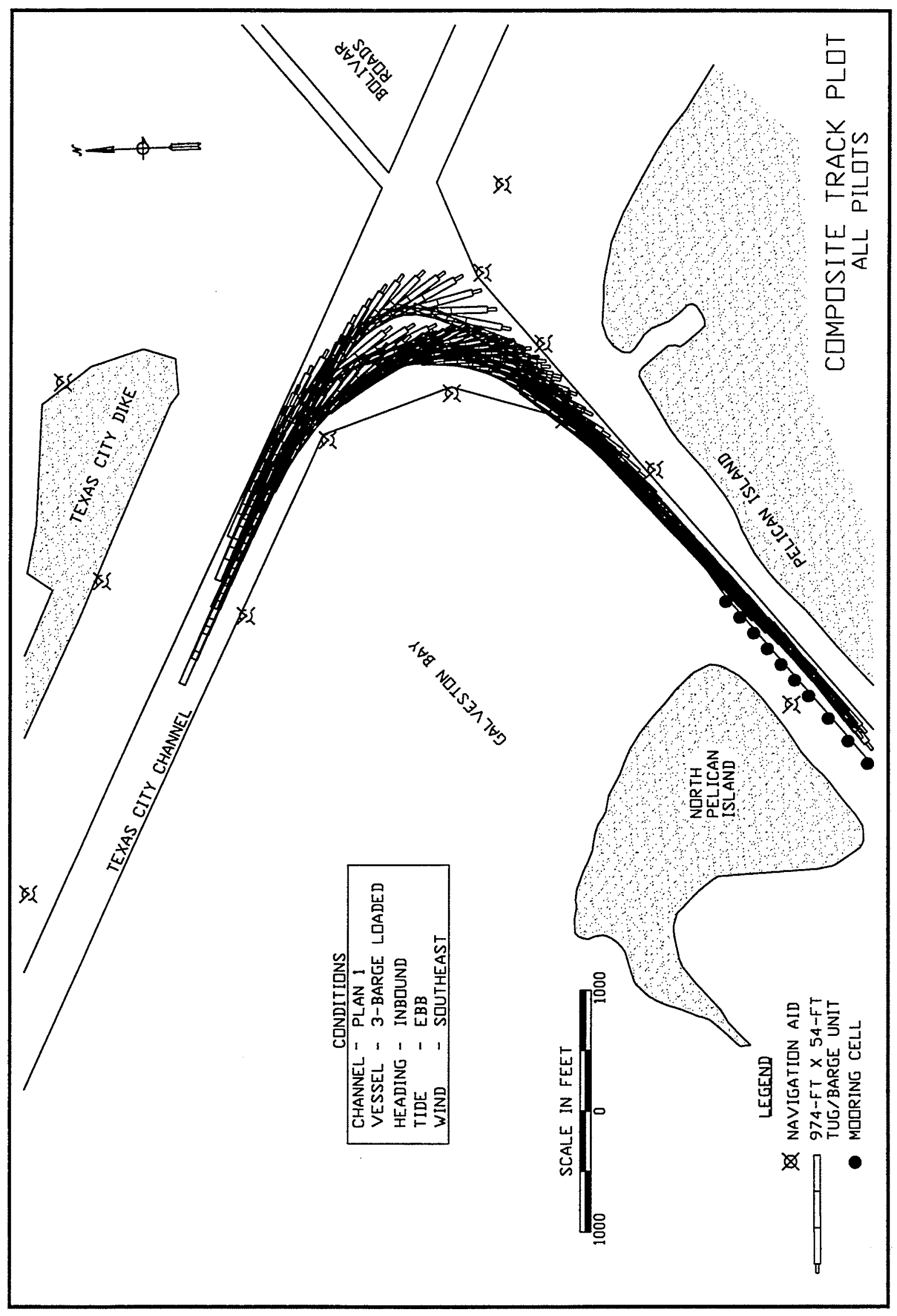

PLATE 67 


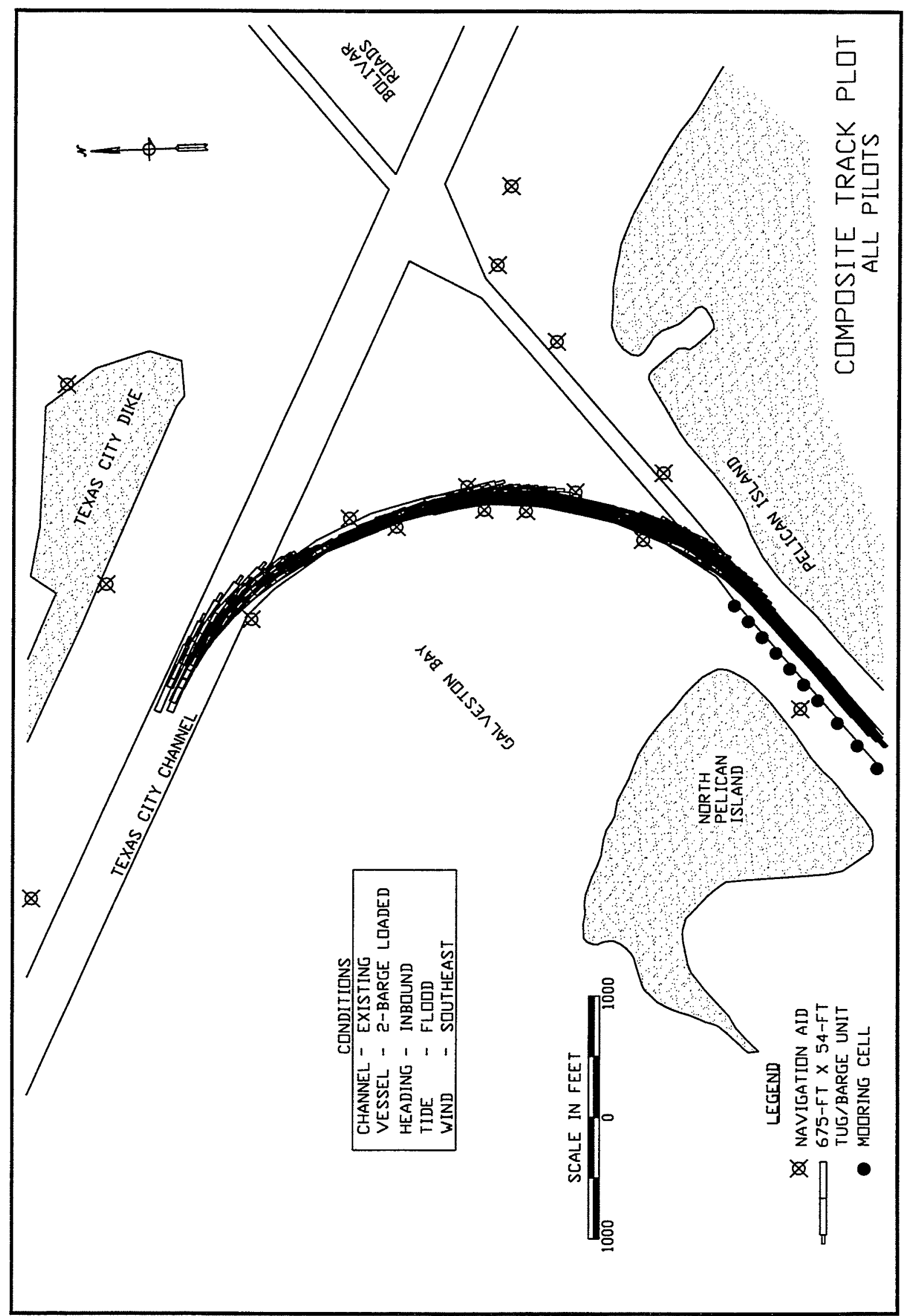

PLATE 68 


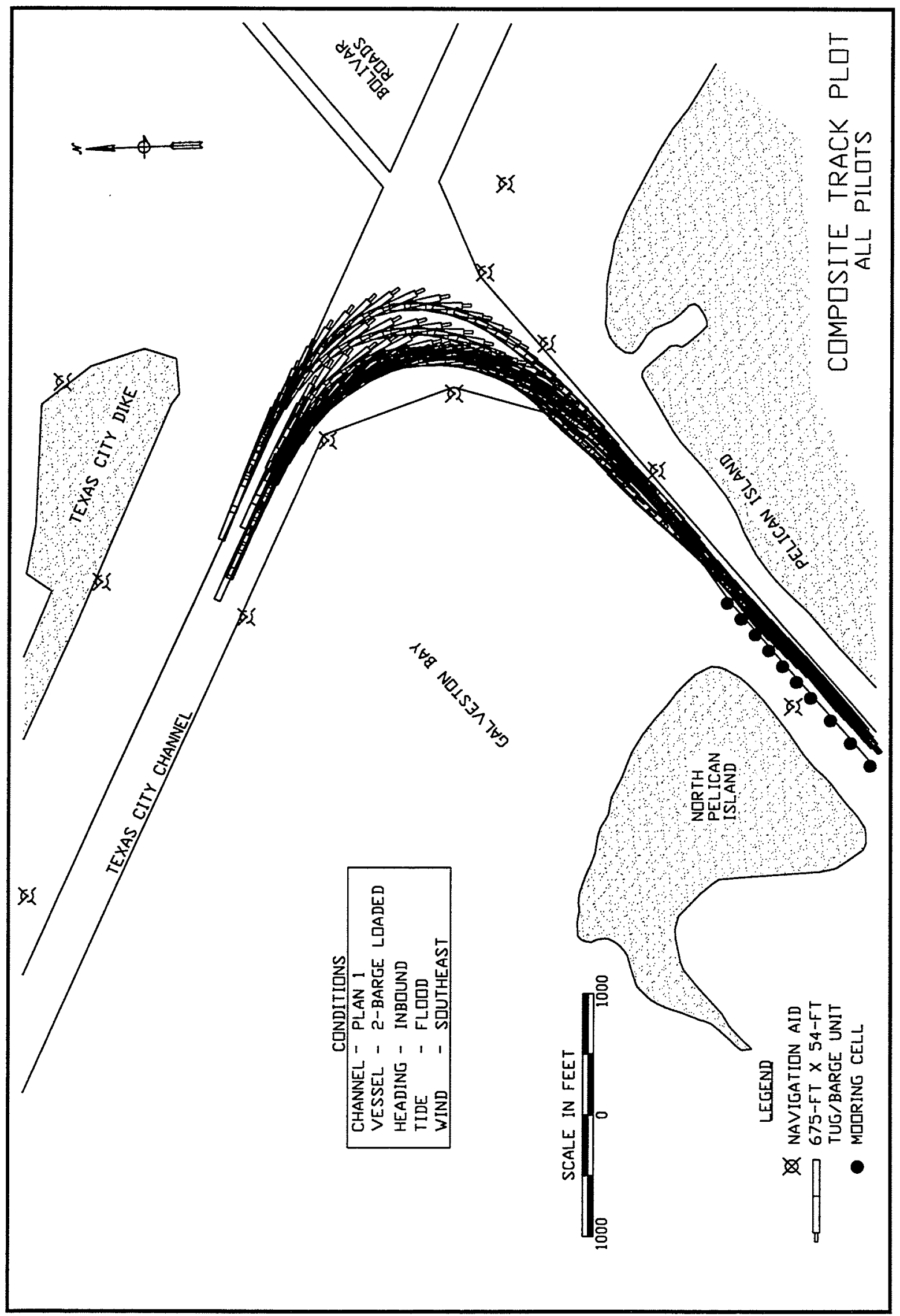

PLATE 69 


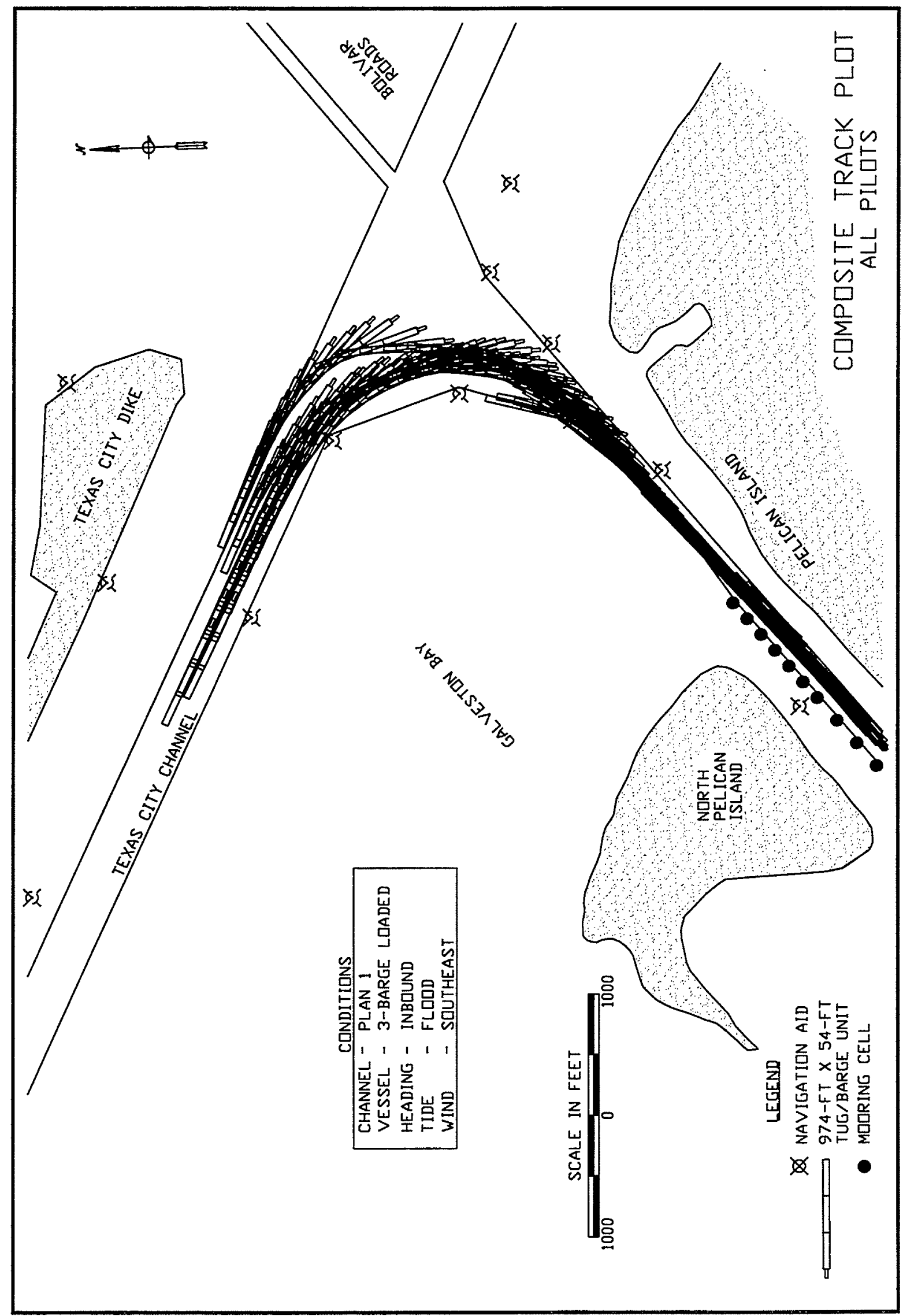

PLATE 70 


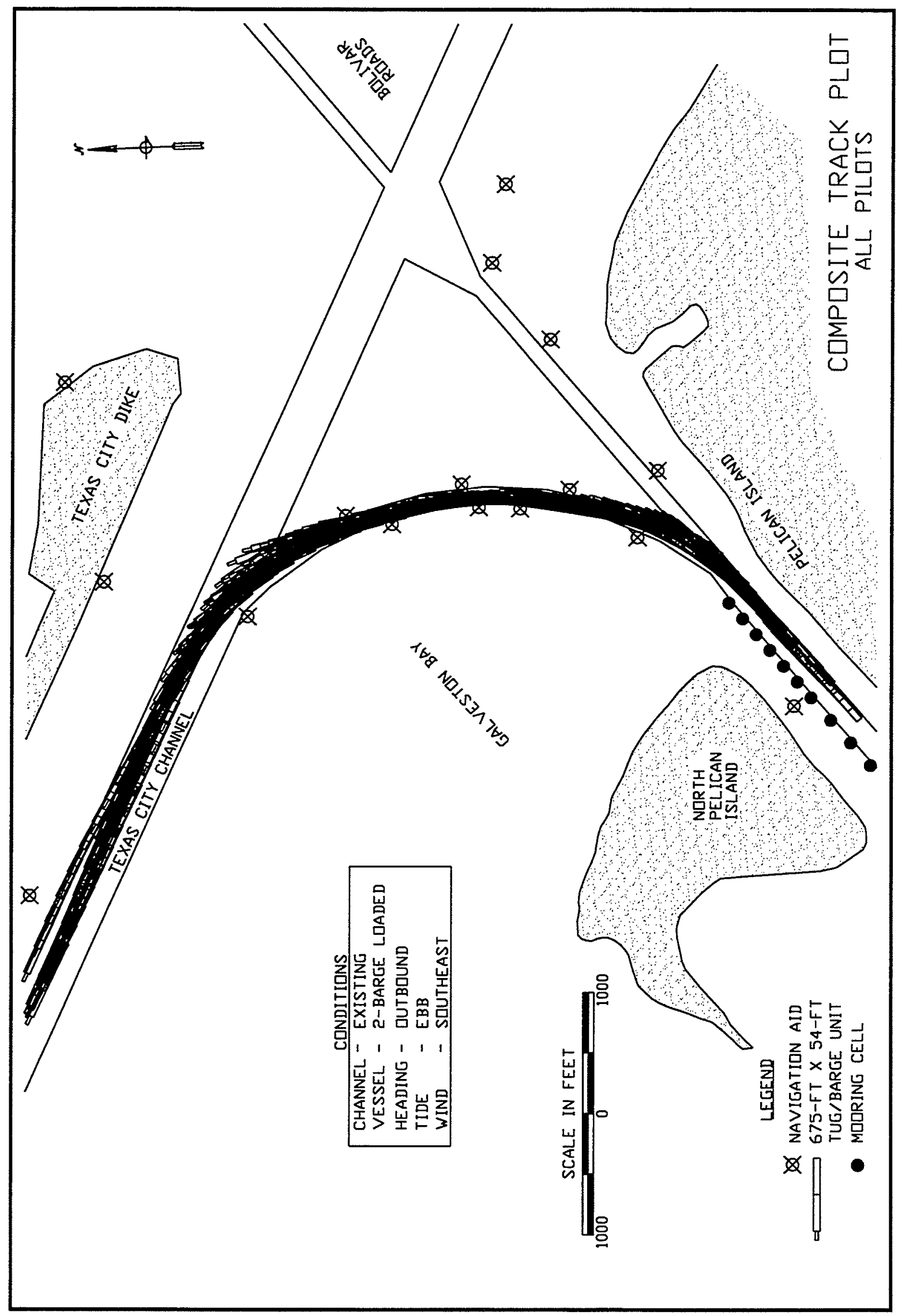

PLATE 71 


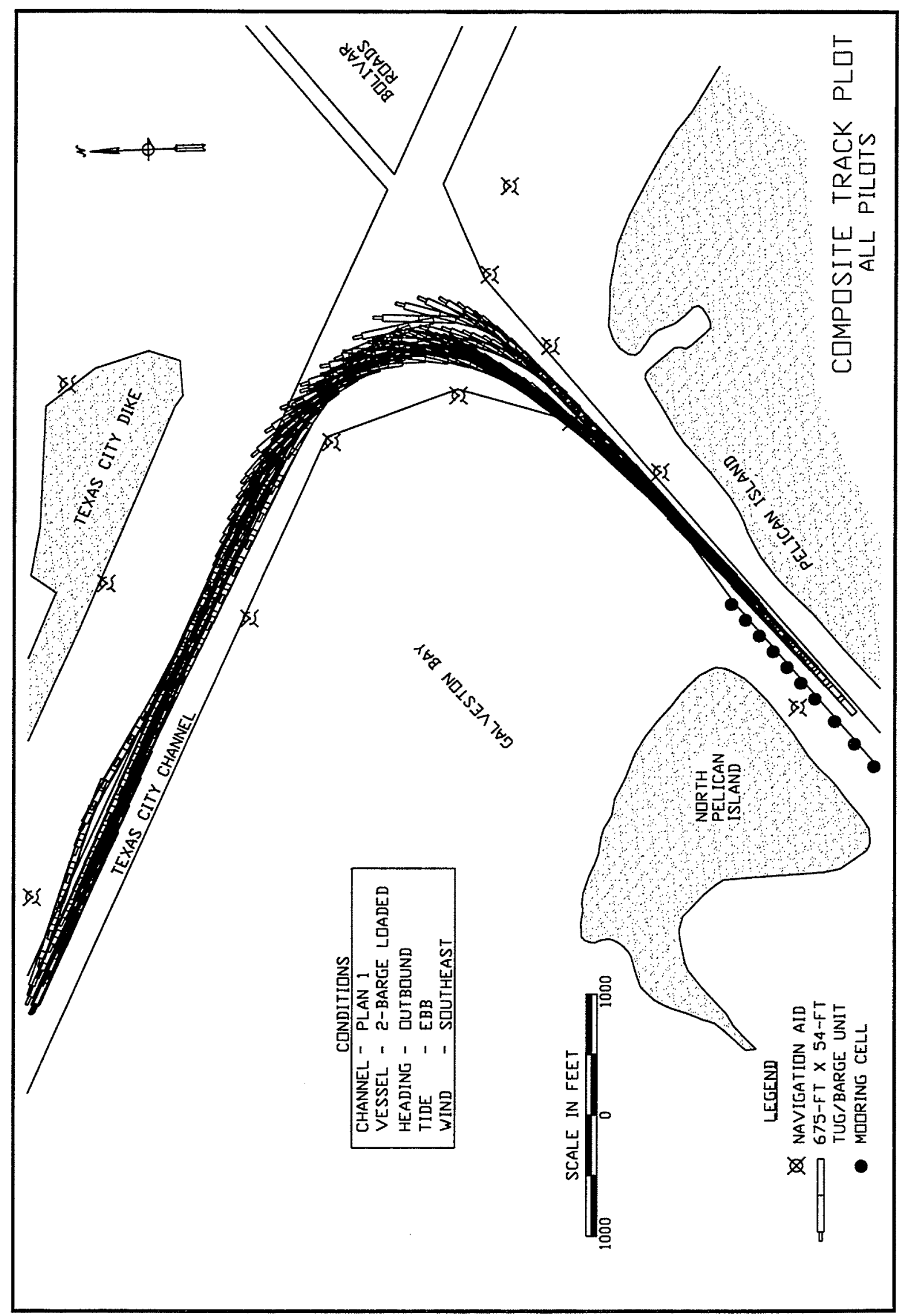

PLATE 72 


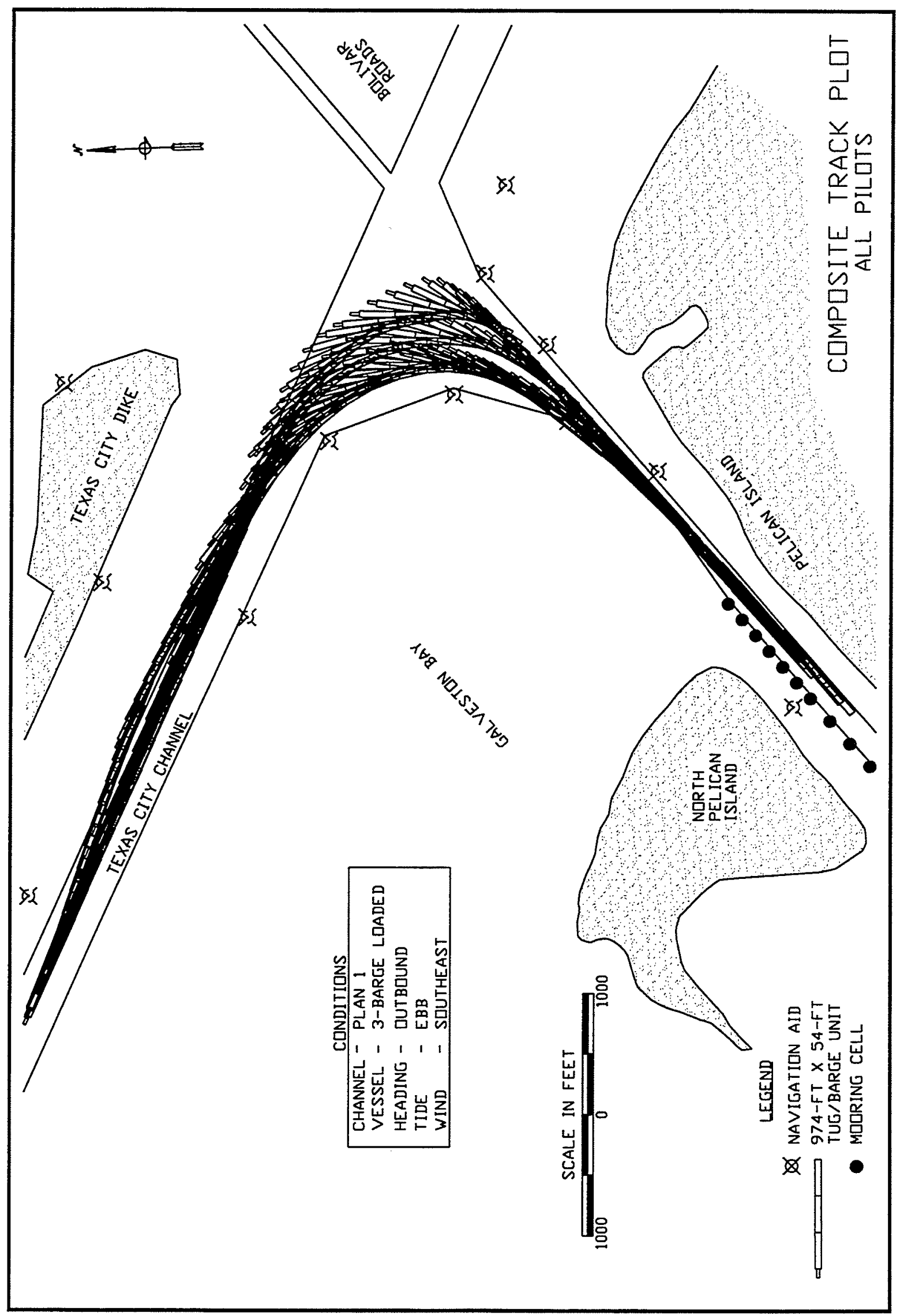

PLATE 73 


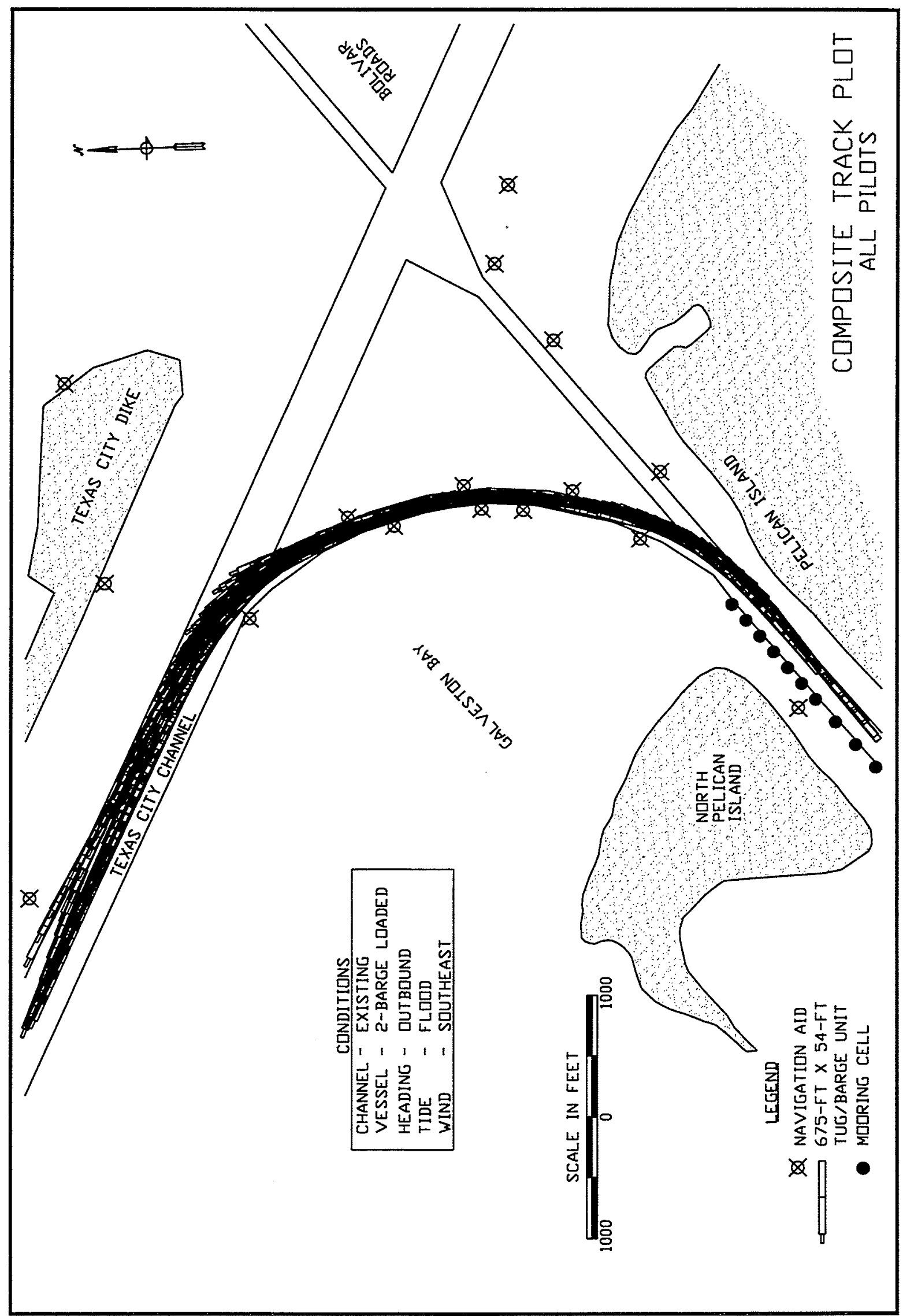

PLATE 74 


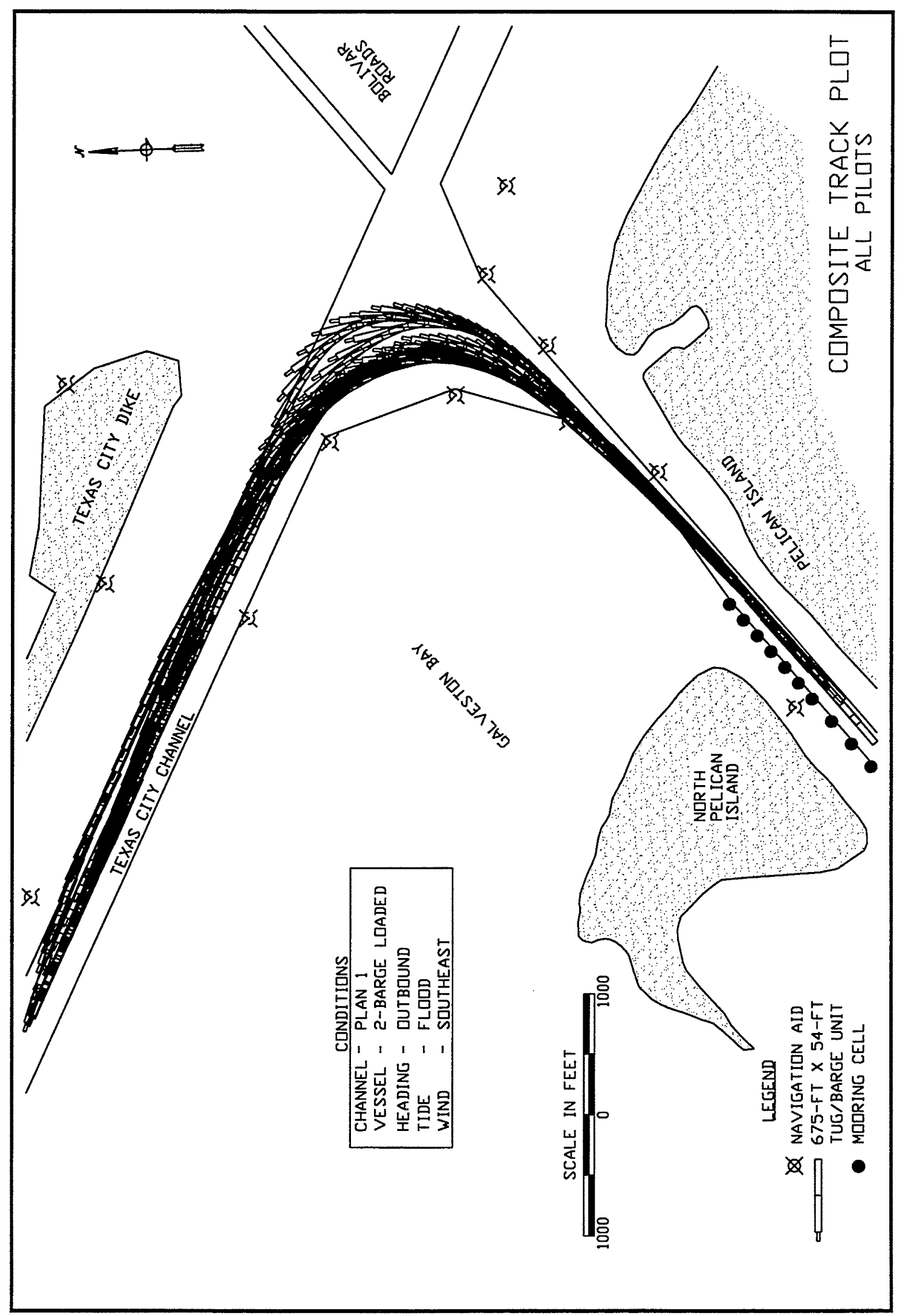

PLATE 75 


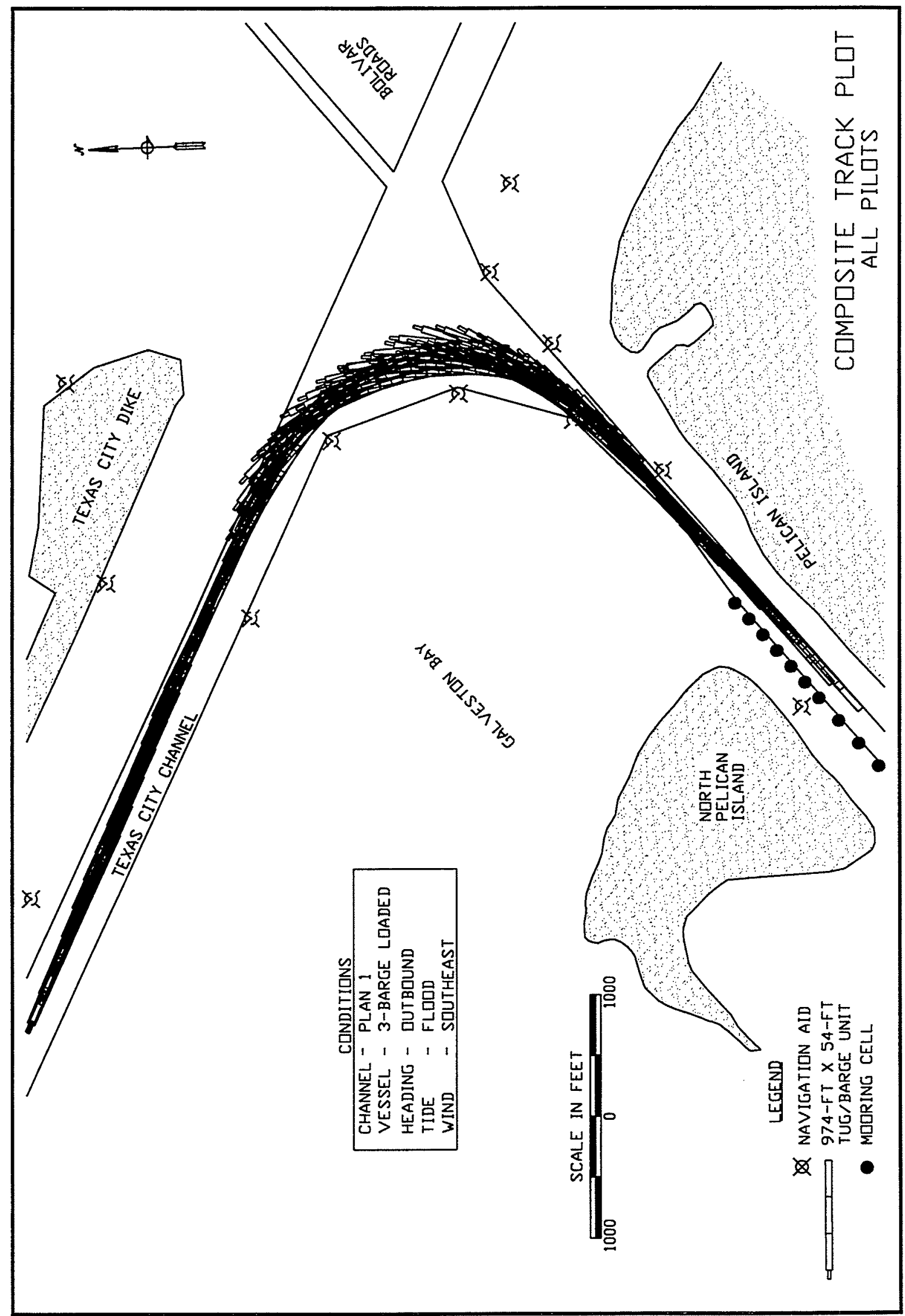

PLATE 76 


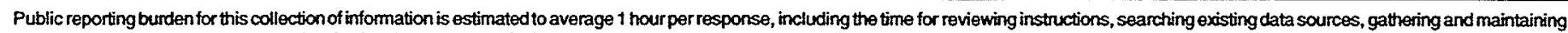

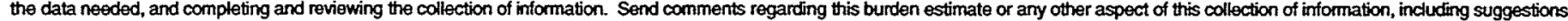

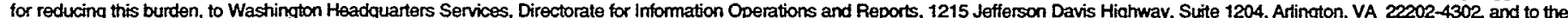
Office of Management and Budget, Paperwork Reduction Project (0704-0188), Washington, DC 20503.

\begin{tabular}{|l|l|l}
\hline 1. AGENCY USE ONLY (Leave blank) & $\begin{array}{c}\text { 2. REPORT DATE } \\
\text { March } 1999\end{array}$ & $\begin{array}{c}\text { 3. REPORT TYPE AND DATES COVERED } \\
\text { Final report }\end{array}$
\end{tabular}

\section{TITLE AND SUBTITLE}

Navigation Simulation Study, Galveston Causeway, Chocolate Bayou, Texas City Wye, Intracoastal Waterway, Texas

\section{AUTHOR(S)}

Donald C. Wilson, Dennis W. Webb, Peggy S. Van Norman

7. ERFORMING ORGANIZATION NAME(S) AND ADDRESS(ES)

U.S. Army Engineer Waterways Experiment Station

3909 Halls Ferry Road, Vicksburg, MS 39180-6199
5. FUNDING NUMBERS
9. SPONSORINGMONITORING AGENCY NAME(S) AND ADDRESS(ES)

U.S. Army Engineer District, Galveston

Galveston, TX 77553-1229
8. PERFORMING ORGANIZATION REPORT NUMBER

Technical Report CHL-99-5

\section{SPONSORING/MONITORING} AGENCY REPORT NUMBER

\section{SUPPLEMENTARY NOTES}

Available from National Technical Information Service, 5285 Port Royal Road, Springfield, VA 22161.

12a. DISTRIBUTION/AVAILABILITY STATEMENT

Approved for public release; distribution is unlimited.

12b. DISTRIBUTION CODE

\section{ABSTRACT (Maximum 200 words)}

A real-time simulation of proposed designs for improving navigation conditions on the Gulf Intra coastal Waterway at the Galveston Causeway, Chocolate Bayou, and Texas City Wye was conducted. The purpose of the study was to determine the effect of proposed improvements on commercial tows navigating the reaches. A numerical model of the existing channels at Galveston Causeway, Chocolate Bayou and Texas City Wye was developed. The model was verified by two towboat pilots that frequently transit the reaches. Tow track data were recorded for a variety of conditions and comparisons made between all alternatives and existing conditions. The investigation was conducted in Vicksburg, MS, on the U.S. Army Engineer Waterways Experiment Station ship simulator.

\section{SUBJECT TERMS}

Channel Design

Chocolate Bayou

Galveston Causeway
Intra coastal

Real-time Simulation Study

Texas City Wye
15. NUMBER OF PAGES

139

16. PRICE CODE
17. SECURITY CLASSIFICATION OF REPORT

UNCLASSIFIED
18. SECURITY CLASSIFICATION OF THIS PAGE

UNCLASSIFIED
19. SECURITY CLASSIFICATION OF ABSTRACT
20. LIMITATION OF ABSTRACT

Standard Form 298 (Rev. 2-89) Prescribed by ANSI Std. 239-18 298-102 
